
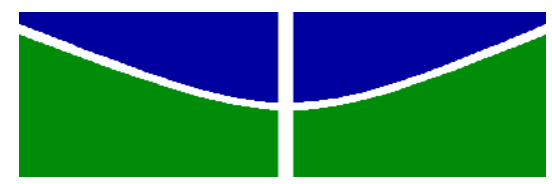

UNIVERSIDADE DE BRASÍLIA CENTRO DE EXCELÊNCIA EM TURISMO MESTRADO PROFISSIONAL EM TURISMO

Erika Cristiane Kilbert

PIRENÓPOLIS - LIMITES E POSSIBILIDADES DE DESENVOLVIMENTO PELO TURISMO 

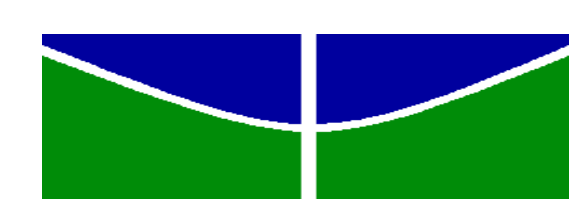

UNIVERSIDADE DE BRASÍLIA CENTRO DE EXCELÊNCIA EM TURISMO MESTRADO PROFISSIONAL EM TURISMO

Erika Cristiane Kilbert

\section{PIRENÓPOLIS - LIMITES E POSSIBILIDADES DE DESENVOLVIMENTO PELO TURISMO}

Dissertação apresentada ao programa de Mestrado Profissional em Turismo da Universidade de Brasília, na área de concentração: Turismo, Cultura e Desenvolvimento Regional, na linha de pesquisa de Desenvolvimento, Políticas Públicas e Gestão no Turismo, como requisito parcial para a obtenção do título de mestre.

Orientadora: Profa. Dra. Marutschka Martini Moesch.

Brasília 
Ficha catalográfica elaborada automaticamente, com os dados fornecidos pelo(a) autor(a)

\begin{tabular}{|c|c|}
\hline K48p & $\begin{array}{l}\text { Kilbert, Erika Cristiane } \\
\text { Pirenópolis - Limites e Possibilidades de } \\
\text { Desenvolvimento pelo Turismo /Erika Cristiane } \\
\text { Kilbert; orientador Marutschka Martini Moesch. - } \\
\text { Brasília, } 2015 . \\
\quad 251 \text { p. } \\
\text { Dissertação (Mestrado - Mestrado Profissional em } \\
\text { Turismo) -- Universidade de Brasília, } 2015 . \\
\text { 1. Turismo. 2. Aspectos Econômicos e Sociais - } \\
\text { Pirenópolis - Goiás. 3. Desenvolvimento . 4. Relações } \\
\text { de Capital e Trabalho. 5. Política Pública de } \\
\text { Turismo. I. Moesch, Marutschka Martini, orient. II. } \\
\text { Título. }\end{array}$ \\
\hline
\end{tabular}




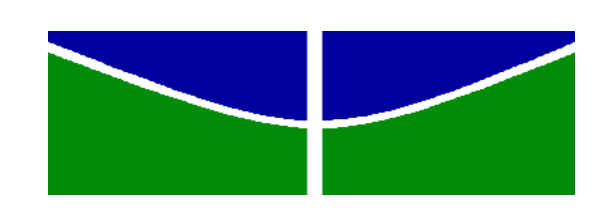

\section{UNIVERSIDADE DE BRASÍLIA \\ CENTRO DE EXCELÊNCIA EM TURISMO \\ MESTRADO PROFISSIONAL EM TURISMO}

Dissertação de autoria de Erika Cristiane Kilbert, intitulada Pirenópolis: Limites e Possibilidades de Desenvolvimento pelo Turismo, submetida ao Centro de Excelência em Turismo da Universidade de Brasília, como parte dos requisitos necessários para a obtenção do grau de Mestre em Turismo, em 10/07/2015, defendida e aprovada pela banca examinadora abaixo assinada:

\begin{tabular}{c}
\hline Profa. Dra. Marutschka Martini Moesch \\
Orientadora \\
CET/UnB \\
Prof. Dr. Neio Campos \\
CET/UnB \\
\hline Prof. Dr. Fernando Luiz Araújo Sobrinho \\
Departamento de Geografia/UnB
\end{tabular}

\section{Suplente:}

Prof. Dr.João Paulo Faria Tasso

$\mathrm{CET} / \mathrm{UnB}$ 
Dedico esta dissertação a meus pais Cida e Carlos, a meu filho ícaro, e meu companheiro Rodrigo, pessoas especiais que tenho tido a alegria de compartilhar o aprendizado do amor e a tornar me mais humana nessa jornada. Dedico ainda à todas as pessoas que acreditam na possibilidade de um turismo mais humanizado e solidário. 


\section{AGRADECIMENTOS}

Primeiramente a Deus, que me concedeu a alegria de viver e por ser minha fonte de força, amor e sabedoria.

Aos meus pais Cida e Carlos, pelo incentivo, apoio em todos os momentos e incondicional amor atribuído ao longo de minha vida.

A minha irmã Sueli, pela dedicação amor e carinho, e ao meu irmão Fulvio pelo intrincado partilhar dessa existência.

Aos meus avós Catarina, Zico e Júlia que, mesmo distantes espiritualmente carrego em meu coração e em minhas doces lembranças.

A meu amado filho Ícaro pelo aprendizado em ser mãe, pela paciência e compreensão ao longo do mestrado, e, pelo amor incondicional.

Ao meu esposo amado e companheiro de jornada Rodrigo, pelo apoio, pelas madrugadas afora de reflexão, alegrias e frustrações no processo de compartilhamento do conhecimento; pela paciência e compreensão nos momentos mais difíceis e por acreditar em meu pontencial na realização desta pesquisa.

As amigas amadas Juliane Noschang ,Thaísa Praxedes e Silvana Gomes pelo incentivo em realizar o mestrado e por partilhar o incrível caminho do conhecimento. Obrigada por compartilhar as alegrias e frustrações desse processo, os livros, os conhecimentos; obrigada pelo apoio, amizade, carinho e amor.

A minha sogra-mãe que por diversas vezes acolheu com carinho meu filho, possibilitando as viagens para Brasília e Goiânia para assistir as aulas e receber orientações.

A amiga Tati, por ter me hospedado por diversas vezes em sua casa.

A minha querida orientadora Profa. Dra. Marutschka Martini Moesch, por quem sou imensamente grata pelos ensinamentos, amizade, hospitalidade e apoio, carinho e compreensão. Obrigada pela orientação, pelas críticas construtivas, pela dedicação e paciência, e, pela oportunidade em ministrar aulas. A aventura do conhecimento não teria sido possível sem o seu altruísmo.

A todos os professores do CET - inclusive aqueles que não tive a oportunidade de ter aulas - que compartilharam os seus conhecimentos, contribuindo dessa forma com as reflexões elaboradas ao longo do processo do mestrado e por incitar e despertar o apreço pelo pensamento crítico e libertador. 
Aos professores Fernando Luiz Araújo Sobrinho e Neio Campos por participar de minhas bancas de qualificação e de defesa, enriquecendo a pesquisa com suas críticas construtivas.

Aos servidores do CET que sempre me atenderam com atenção e gentileza e que possibilitaram o esmero a estrutura física do CET, possibilitando um ambiente tranquilo, limpo e organizado para o nosso aprendizado.

A todos os colegas de mestrado pelo convívio e pelo compartilhar de experiências. Agradecimentos especiais: á querida Elaine, que me acolheu com carinho junto á sua família por diversas vezes, pelo convívio e pelas reflexões acadêmicas e pessoais. Á Tati, que com sua alegria e solidariedade encantou meu coração. Á Carol, por ter me hospedado com carinho e por ceder a sua casa para a realização de todas as confraternizações do mestrado. Ao querido Elias pelo carinho, convívio e compartilhar de ideias. Á Dani pelo convívio em sala de aula e no evento ANPTUR.

Agradeço as instituições que abriram as portas para que esse trabalho pudesse ser concretizado, em especial à Secretaria Municipal de Turismo de Pirenópolis, na pessoa do secretário Sérgio Rady, á Secretaria Municipal de Finanças de Pirenópolis, na pessoa da secretária Vanessa Pina pela disposição em conceder as entrevistas e ceder 0 acervo documental, nos quais embasei a pesquisa.

Agradeço a todos os trabalhadores e empreendedores de Pirenópolis que concederam as entrevistas e contribuíram de forma vital com a realização desse trabalho.

A colega Priscilla Teixeira pelo auxílio em momentos da fase da pesquisa empírica.

Expresso meus sinceros agradecimentos a todos que possibilitaram de alguma forma a concretização desse trabalho. 
"Nenhum ser humano é uma ilha... por isso não perguntem por quem os sinos dobram. Eles dobram por cada um, por cada uma, por toda a humanidade. Se grandes são as trevas que se abatem sobre nossos espíritos, maiores ainda são as nossas ânsias por luz. (...) As tragédias dão-nos a dimensão da inumanidade de que somos capazes. Mas também deixam vir à tona o verdadeiramente humano que habita em nós, para além das diferenças de raça, de ideologia e de religião. E esse humano em nós faz com que juntos choremos, juntos nos enxuguemos as lágrimas, juntos oremos, juntos busquemos a justiça, juntos construamos a paz e juntos renunciemos à vingança”.(Leonardo Boff). 


\section{RESUMO}

Compreendendo o turismo enquanto um fenômeno de uma prática social, a análise do desenvolvimento deste vem a ser o tema central dessa dissertação, que tem como objetivo analisar as relações de capital e trabalho, e, as transformações sócio econômicas e suas influências no processo de desenvolvimento do Turismo no município de Pirenópolis. A expansão do Turismo no município ocorre desde os anos 1970, e intensificou se a partir dos anos 1990, devido à melhoria dos acessos, incentivo das políticas públicas de turismo e investimentos em infraestrutura de hospedagem e alimentação. Considerando este cenário, a investigação teve um caráter qualitativo, de nível exploratório e explicativo, buscando compreender das relações de capital e trabalho e as transformações sócio - econômicas que ocorreram no município após a instauração do turismo, desvelando os limites e as possibilidades de um desenvolvimento sustentável. A realização dessa pesquisa ocorreu em três momentos: no primeiro buscou se construir a teoria do objeto pela análise teórica a respeito do tema, a partir da reconstrução dos conceitos: Desenvolvimento e suas multíplices interpretações; Turismo; relações de capital e trabalho; território e práticas sociais, e, políticas públicas e planejamento do turismo. Em um segundo momento, foram analisados diferentes documentos referentes ao planejamento do turismo e dados do Ministério do Trabalho, posteriormente foram entrevistados os principais atores intrínsecos ao processo de desenvolvimento. A partir da pesquisa teórica e empírica, foi concretizada a análise para identificar se o turismo estabelecido é uma prática social que propicia o desenvolvimento sustentável do município em sua totalidade.

Palavras-chaves: Desenvolvimento, Turismo, Pirenópolis, Relações de Capital e trabalho. 


\begin{abstract}
Understanding tourism as a phenomenon of a social practice, the analysis of the development of this becomes the central theme of this dissertation, which aims to analyze the relations of capital and labor, and the socio-economic transformations and their influence in the development process of Tourism in the city of Pirenópolis. The expansion of tourism in the city takes place since the 1970s, and intensified from the 1990s, due to improved access, encouragement of public policies and investments in hosting infrastructure and power. Considering this scenario, the research had a qualitative, exploratory and explanatory level, seeking to understand the relations of capital and labor and socio-economic transformations that have taken place in the city after the establishment of tourism, revealing the limits and possibilities for sustainable development. The realization of this research took place in three stages: the first sought to build the theory of the object by theoretical analysis on the subject, from the reconstruction of concepts: development and its multifold interpretations; Tourism and public policy; space; territory; relations of capital and labor, and citizenship. In a second step, we analyzed different documents related to tourism planning and Ministry of Labor data, were later interviewed the main actors intrinsic to the tourism development process. From the theoretical and empirical research, the analysis was completed to identify whether the established tourism is a social practice that fosters the development of the city in its entirety.
\end{abstract}

Keywords: Development, Tourism, Pirenópolis, capital and labor relations. 


\section{LISTA DE ILUSTRAÇÕES}

\section{FIGURAS}

Figura 1 - Programa de Regionalização do Turismo - Mapa das regiões turísticas

de Goiás.

Figura 2 - Região do Ouro - Pirenópolis.........................................................

Figura 3 - Mapa da regionalização Goiás - 2013............................................99

Figura 4 - Sistema Estadual de Turismo........................................................100

Figura 5 - Esquema do roteiro de análise dos documentos e entrevistas............107

Figura 6 - Esquema da Triangulação............................................................114

\section{QUADROS}

Quadro 1 - Modelo utilizado para interpretação de trechos do discurso dos Documentos e das entrevistas.

Quadro 2 - Contradições das características do modo de produção capitalista "Fordista" e do modo de produção capitalista "Flexível"

\section{TABELAS}

Tabela 1 - Indicadores socioeconômicos e PIB (2012) - Pirenópolis 169

Tabela 2 - Quantidade de empreendimentos das Atividades Características do Turismo -2013

\section{GRÁFICOS}

Gráfico 1 - Empregos formais considerando todas as Atividades Características do Turismo (2003 a 2013). 179

Gráfico 2 - Faixa salarial dos empregos formais considerando todas as Atividades Características do Turismo (2003 a 2013) 181 


\section{LISTA DE SIGLAS}

ABAV Associação Brasileira de Agentes de Viagem

ACTS Atividades Características do Turismo

ACVP Associação dos Condutores de Visitantes de Pirenópolis

AGETUR Agência Goiana de Turismo

APA Área de Proteção Ambiental

APLS Arranjos Produtivos Locais

BID Banco Interamericano de Desenvolvimento

CAT Centro de Atendimento ao Turista

CELG Companhia Energética de Goiás

CEPAL Comissão Econômica para a América Latina e Caribe

CNTUR Conselho Nacional de Turismo

COMBRATUR Comissão Brasileira de Turismo

COMTUR Conselho Municipal de Turismo

DAIA Distrito Agroindustrial de Anápolis

DETUR Departamento de Turismo de Goiás

DHE Dialética Histórico Estrutural

ECAD Escritório Central de Arrecadação

EMBRATUR Empresa Brasileira de Turismo

FAT Fundo de Amparo ao Trabalhador

FICA Festival Internacional de Cinema Ambiental

FLIPIRI Festa Literária de Pirenópolis

FUMTUR Fundo Municipal de Turismo

FUNGETUR Fundo Geral do Turismo

GTT Grupo de Trabalho do Turismo

IADH Instituto de Assessoria para o Desenvolvimento Humano 


\begin{tabular}{|c|c|}
\hline IBAMA & Instituto Brasileiro do Meio Ambiente \\
\hline IBGE & Instituto Brasileiro de Geografia e Estatística \\
\hline IBRAM & Instituto Brasileiro de Museus \\
\hline IDH & Índice de Desenvolvimento Humano \\
\hline IPES & Instituto de Pesquisa Econômica e Social de Goiás \\
\hline IPHAN & Instituto do Patrimônio Histórico e Artístico Nacional \\
\hline IPTUR & Instituto de Pesquisas Turísticas \\
\hline MTUR & Ministério do Turismo \\
\hline OMT & Organização Mundial do Turismo \\
\hline ONG & Organização Não Governamental \\
\hline ONU & Organização das Nações Unidas \\
\hline RAIS & Relação Anual de Informações Sociais \\
\hline PLANFOR & Plano Nacional de Qualificação do Trabalhador \\
\hline PIB & Produto Interno Bruto \\
\hline PNMT & Plano Nacional de Municipalização do Turismo \\
\hline PNUD & Programa das Nações Unidas para o Desenvolvimento \\
\hline PROCON & Órgão de Proteção e Defesa do Consumidor \\
\hline PRT & Programa de Regionalização do Turismo \\
\hline PDITS & $\begin{array}{l}\text { Plano de Desenvolvimento Integrado do Turismo Sustentável do Polo } \\
\text { do Ouro }\end{array}$ \\
\hline PED & Plano de Execução Descentralizada \\
\hline PET & Plano Estadual de Turismo \\
\hline PPAs & Planos Plurianuais \\
\hline PRONATEC & Programa Nacional de Acesso ao Ensino Técnico e Emprego \\
\hline RPPN's & Reservas Particulares do Patrimônio Natural \\
\hline SAMU & Serviço de Atendimento Móvel de Urgência \\
\hline SEBRAE & Serviço Brasileiro de Apoio às Micro e Pequenas Empresas \\
\hline SEMA & Secretaria Estadual do Meio Ambiente de Goiás \\
\hline
\end{tabular}


SENAC Serviço Nacional de Aprendizagem Social

SEPLAN Secretaria de Planejamento

SINDETUR Sindicato dos Empregados de Turismo

SINDHORBS Sindicato de Hotéis, Bares, Restaurantes e Similares

SINGTUR Sindicato dos Gerentes Empresariais de Turismo

UEG Universidade Estadual de Goiás

UNEP United Nations Environment Programme

UNESCO Organização das Nações Unidas para a Educação, a Ciência e a Cultura

WTTC World Tourism Travel Council

WWF World Wild Foundation 


\section{SUMÁRIO}

INTRODUÇÃO

CAPÍTULO I. COMPREENDENDO A TRAJETÓRIA DO DESENVOLVIMENTO E

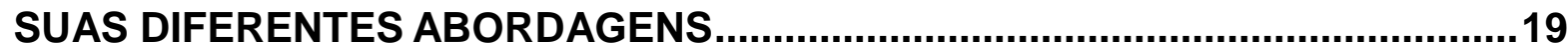

1.1 O LONGO PERCURSO DA TEORIA DO DESENVOLVIMENTO E SUAS ABORDAGENS .20

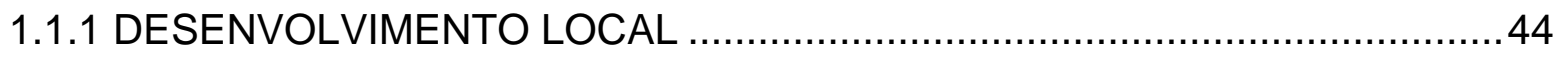

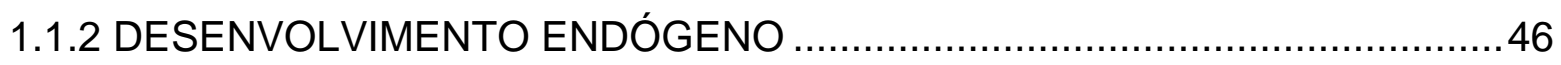

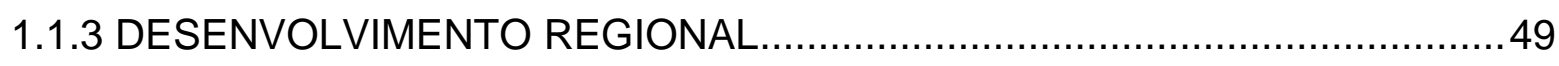

1.1.4 DESENVOLVIMENTO SUSTENTÁVEL ...................................................

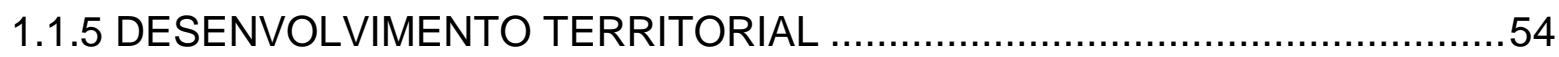

1.2 A FORMAÇÃO DO TERRITÓRIO E O DESENVOLVIMENTO DAS PRÁTICAS SOCIO ECONÔMICAS EM GOIÁS E PIRENÓPOLIS - BREVE HISTÓRICO.........55

1.3 PIRENÓPOLIS: PERCORRENDO A TRILHA DOTURISMO ..........................64

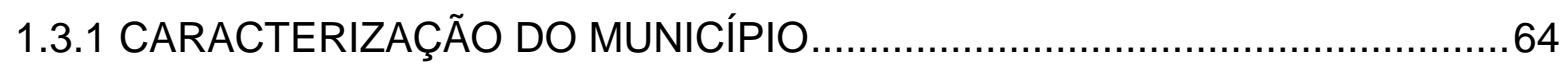

1.3.2 PIRENÓPOLIS E A LONGA CAMINHADA COM VISTAS AO DESENVOLVIMENTO 68

1.4 O DESENVOLVIMENTO VISTO A PARTIR DA POLÍTICA PÚBLICA DO TURISMO NO BRASIL E NO ESTADO DE GOIÁS ............................................... 80

CAPÍTULO II . CONSIDERAÇÕES TEÓRICO-METODOLÓGICAS ......................103

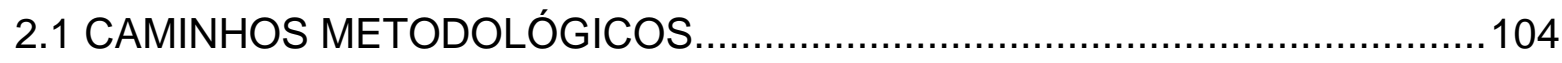

2.2 A DIALÉTICA HISTÓRICO ESTRUTURAL (DHE) PARA A COMPREENSÃO DO PROBLEMA DE PESQUISA - CATEGORIAS ANALÍTICAS .....................114

2.2.1 LEIS E CATEGORIAS ESSENCIAIS DA DIALÉTICA HISTÓRICO

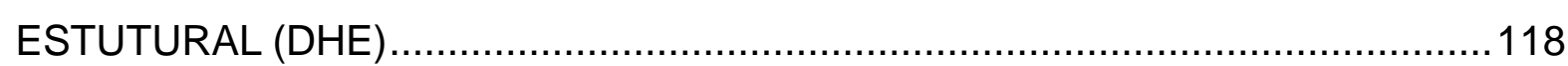

2.3 QUADRO TEÓRICO PARA A SUPERAÇÃO DA REALIDADE RECONSTRUÇÃO DAS CATEGORIAS OPERATÓRIAS...................................123

2.3.1 DESENVOLVIMENTO SUSTENTÁVEL E INCLUDENTE ..........................123

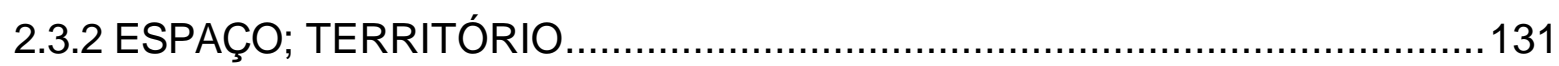

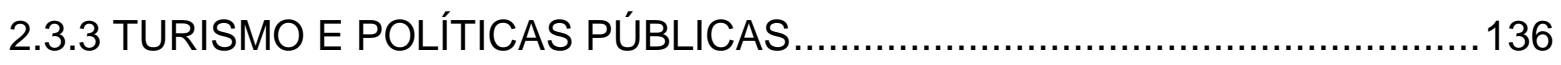

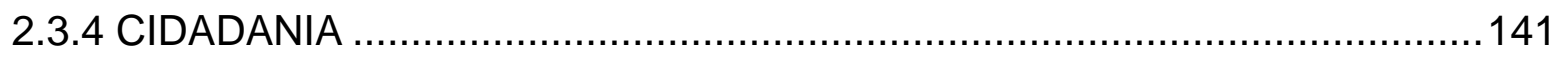

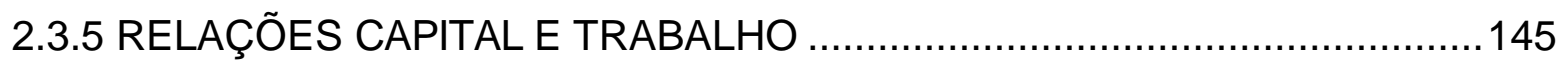


CAPÍTULO III. PIRENÓPOLIS: LIMITES E POSSIBILIDADES DE TRANSFORMAÇÃO DAS PRÁTICAS SOCIOECONÔMICAS PELO TURISMO DESAFIOS PARA UM DESENVOLVIMENTO SUSTENTÁVEL E INCLUDENTE 152

3.1 OS SUJEITOS REPRODUTORES DO TURISMO - Ministério do Turismo e Secretaria de Turismo de Pirenópolis. .................................................................152

3.2 OS SUJEITOS CONSUMIDORES DO TURISMO - Empresários e

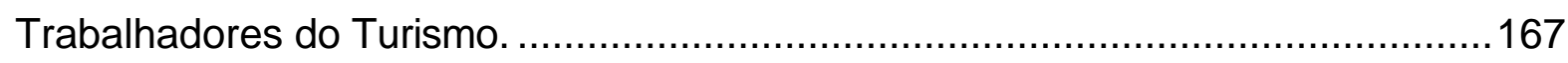

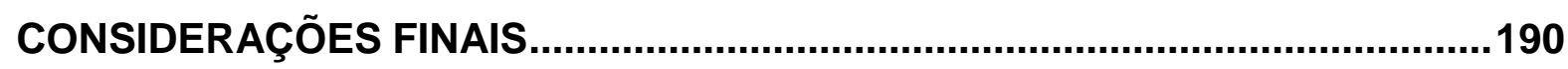

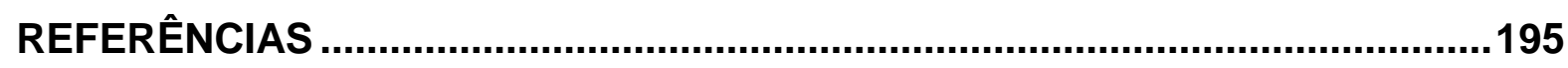

APÊNDICE A - Entrevista: Gestor Municipal do Turismo de Pìrenópolis........203 APÊNDE B - Entrevista: Membros das Associações Representativas e Empresários do Turismo Local.................................................................205 APÊNDICE C - Entrevista: Trabalhadores do Turismo Local .........................207 APÊNDICE D - Quadro interpretativo de trechos do discurso do documento: Plano Nacional de Turismo 2003-2007 .......................................................209 APÊNDICE E - Quadro interpretativo de trechos do discurso do documento: Plano Nacional de Turismo 2007-2010......................................220 APÊNDICE F- Quadro interpretativo de trechos do discurso do documento: Plano Nacional de Turismo 2013-2016 ....................................................231 APÊNDICE G - Quadro interpretativo de trechos do discurso do documento: Plano Municipal de Turismo de Pirenópolis 2012-2016...............240 APÊNDICE H - Quadro interpretativo de trechos do discurso do documento: Plano Diretor de Pirenópolis - 2002 ...........................................................246 


\section{INTRODUÇÃO}

Para além da delimitação entre oferta e demanda turísticas, o turismo é um fenômeno complexo que se faz presente na sociedade contemporânea. Podese afirmar que a expansão do turismo deu-se simultaneamente à expansão do capitalismo, os avanços tecnológicos que propiciaram o crescimento da industrialização, como as comunicações e os transportes, impulsionaram o turismo como atividade econômica.

As diversas crises do capitalismo que se deram ao longo do tempo assinalaram a ineficiência do modelo industrial em propiciar o desenvolvimento.

A concepção de progresso e desenvolvimento que vem sendo construída a partir dos teóricos da economia clássica, não tem se mostrado suficientemente capaz de construir uma sociedade mais justa. O desenvolvimento entendido na perspectiva de que se dá pela capacitação dos sujeitos e seus interesses individuais que, acompanhados pela divisão do trabalho e ampliação dos mercados, resultam em geração de riqueza, proporcionando consequentemente o bem estar das pessoas e da sociedade - como um processo linear de causaefeito, reduzindo ao máximo a inferência do estado em diversos setores, sobretudo na economia é a essência da fórmula que perdura até os dias atuais.

O estado garantidor do acesso aos bens sociais (alimentação, moradia, segurança, educação, saúde, lazer) e à todos os direitos (civis, políticos, sociais, humanos) dos sujeitos e da coletividade, ao longo do processo histórico do sistema capitalista, rende-se à ideologia capitalista.

Essa dinâmica resulta em um processo que tem assegurado cada vez mais a acumulação e a reprodução de capital, aprofundando ainda mais a desigualdade social no mundo.

O trabalho elemento fundante da vida humana, porque condição de sua existência social, é também um dos elementos integrantes do processo produtivo. Dentre a terra, o capital e o trabalho, este último é o elemento fundante de toda a criação de valores de uso, "como trabalho útil, é o trabalho por isso, uma condição da existência do homem, independentemente de todas as formas de sociedade, eterna necessidade natural de mediação do 
metabolismo entre homem e natureza" (Marx ,2001, p.50).

Se por um lado, é ponto de partida do processo da realização criativa, da humanização, por outro, na sociedade capitalista é desantropomorfizado, degradado, precarizado, convertido em um meio de subsistência e não primeira necessidade de realização humana, assumindo a atribuição de valorização e acumulação do capital. Como expressão da realidade existente na sociedade regida pelo valor, tem se a dialética da acumulação/privação, do possuidor/despossuído, da riqueza/miséria.

A tensão da relação capital/trabalho se faz presente e em seu rastro carrega todas as adversidades provenientes desta, desigualdade, exclusão e exploração.

Neste contexto as práticas turísticas que seguiram o modelo capitalista também precisam ser reconsideradas em outras perspectivas, uma vez que geraram na maioria dos casos o mesmo padrão excludente, desigual e exploratório de desenvolvimento da produção capitalista industrial.

O problema orientador dessa investigação é entender se o Turismo pode vir a ser um novo instrumento de transformação das práticas socioeconômicas no município de Pirenópolis rompendo ao continuísmo das tradicionais formas capitalistas de exploração do território.

Para responder ao problema de pesquisa proposto, tem-se como objetivo geral: analisar as relações de capital / trabalho no município de Pirenópolis e sua influência na caracterização do processo de desenvolvimento do Turismo local, desvelando os limites $e$ as possibilidades de um desenvolvimento sustentável e includente pelo turismo. Os objetivos específicos são:

a) Analisar se a políticas públicas do turismo implementadas no município contribuíram para um desenvolvimento sustentável e includente;

b) Identificar e analisar que tipo de desenvolvimento o turismo está propiciando em Pirenópolis;

c) Analisar se existe um continuísmo das tradicionais formas capitalistas de exploração do território em suas práticas de reprodução capital/trabalho pelo turismo no município.

Para trilhar esse caminho foram construídas as seguintes questões de 
pesquisa: $O$ turismo está sendo um novo instrumento de transformação das práticas sócio econômicas em Pirenópolis?

Há um Continuísmo das tradicionais formas capitalistas de exploração do território leia se mineração agricultura e pecuária em suas formas de reprodução capital trabalho pelo turismo?

Em que medidas as políticas públicas de turismo implementadas contribuem ou não para um desenvolvimento sustentável e includente.

Que tipo de desenvolvimento o turismo está propiciando e para quem?

O primeiro capítulo aborda o processo histórico de elaboração do conceito de desenvolvimento, buscando identificar as concepções e diferentes abordagens deste para relacionar suas acepções ás práticas adotadas pelos sujeitos que atuam no turismo. Faz-se uma análise acerca dos principais fatos $e$ transformações socioeconômicas que ocorreram no território de Goiás e Pirenópolis ao longo do tempo, apresentando as reverberações das políticas públicas e das ações civis no que concerne ás práticas turísticas no município, no processo de evolução do turismo em Pirenópolis.

No segundo capítulo busca-se desconstruir a concepção de desenvolvimento pelo turismo, analisando criticamente seu processo fazendo uso da dialética histórico estrutural, referencial metodológico deste trabalho. O método histórico estrutural visa analisar a realidade empírica dinâmica dentro de um contexto histórico específico em uma relação dialética com a realidade.

Para auxiliar na análise da realidade lança-se mão das categorias operatórias: desenvolvimento sustentável e includente a partir de Ignacy Sachs e Mario Beni, turismo e políticas públicas a partir de Mario Beni, Sérgio Molina, Marutschka Moesh, espaço e território a partir de Milton Santos, Claude Raffestin, Ana Fani Carlos e Henri Lefebvre; cidadania a partir de Paulo Meksenas, Susana Gastal, Marutschka Moesh, Pedro Demo e Maria de Lourdes Manzini Covre, relação capital/trabalho a partir de Karl Marx e Friedrich Engels, Ricardo Antunes e David Harvey.

No terceiro e último capítulo, é apresentada a análise das evidencias do estudo de caso, que se deu em duas etapas. A primeira etapa é centrada na pesquisa documental, dessa forma dirigiu-se a atenção em um primeiro momento para os reprodutores do processo de desenvolvimento do turismo, ou 
seja, MTUR, Goiás Turismo, Secretaria Municipal de Turismo, Planejamento Urbano e Desenvolvimento Econômico Sustentável, analisando os conteúdos presentes nos discursos contidos nas políticas públicas (são os elementos produzidos pelo meio). A segunda etapa, é centrada na análise dos dados obtidos na pesquisa de campo, voltando a atenção para os consumidores, neste caso os empreendedores e os trabalhadores do turismo, identificando e analisando os processos e produtos que são originados pela e na estrutura social, averiguando as percepções do sujeito (formas verbais), através de entrevistas com pessoas fontes do processo de desenvolvimento do turismo no município.

Por fim, são apresentadas as considerações finais, onde a pesquisadora tece suas conclusões possíveis e temporais, na busca da objetividade possível do compromisso do conhecimento comprometido com o desvelamento ideológico das inúmeras verdades possíveis diante das incertezas históricas, propondo nova tese a ser contestada, novas formas de percepção de desenvolvimento do turismo.

\section{CAPÍTULO I. COMPREENDENDO A TRAJETÓRIA DO DESENVOLVIMENTO E SUAS DIFERENTES ABORDAGENS}

São apresentadas neste capítulo as principais concepções de desenvolvimento e crescimento econômico que nortearam as ações públicas e privadas ao longo dos anos. Considera-se como campo de conhecimento investigado neste trabalho o turismo, objeto de algumas dessas ações públicas e privadas com vistas a fomentar o desenvolvimento.

Este capítulo dá conta, teoricamente, da multidimensionalidade a que está submetido o desenvolvimento, esta ação requer um esforço de reflexão na tentativa de trazer à luz a compreensão das diferentes concepções sobre desenvolvimento - construto este que se encontra em constante e permanente evolução e reinvenção. A tarefa é árdua, necessária e crucial para o avanço de um campo de reflexão reducionista para um campo de reflexão complexo da realidade, considerando as contradições que esta tenha em seu arcabouço. A intenção em se trazer esclarecimentos convergentes, visa contribuir para uma melhor compreensão sobre o desenvolvimento no contexto que se busca para 0 estudo do objeto em foco. 
Abarcará ainda o processo de formação do território de Goiás e Pirenópolis e do desenvolvimento das práticas socioeconômicas que ocorreram ao longo do tempo. Concomitante revelando as políticas públicas implementadas com vistas a dar conta das influências no município de Pirenópolis.

\subsection{O LONGO PERCURSO DA TEORIA DO DESENVOLVIMENTO E SUAS ABORDAGENS}

O termo desenvolvimento incorpora se nas teorias e práticas sociais, por meio das diferentes áreas do conhecimento, a biologia, a sociologia, a antropologia, a ciência política, dentre outras, mas é primordialmente na ciência econômica que ele encontra seu eco de forma mais robusta. Ao longo de seu percurso histórico, de forma mais acentuada na contemporaneidade, com o advento do capitalismo, o termo desenvolvimento fora sendo construído e difundido - á reflexão de seus teóricos, em sua maioria economistas - de acordo com diferentes acepções, que, por sua vez, influenciaram a formação de algumas concepções diferentes de sociedade, como sociedade do crescimento, sociedade do bem estar social, sociedade de consumo, sociedade sustentável, dentre outras.

Para buscar uma compreensão acerca dessas diferentes concepções e acepções do desenvolvimento, é fundamental recorrer se primeiramente ás teorias clássicas da economia, (as quais concebem desenvolvimento na acepção de crescimento) e o contexto político, social e econômico aos quais elas foram elaboradas, pois estas teorias são à base da evolução do pensamento da temática.

A teoria econômica clássica do século XVIII tem como expoente Adam Smith, economista e filósofo iluminista inglês, que inspirado por algumas ideias de seu professor Francis Hutcheson e influenciado por David Hume e Dudley North, entre outros, concebe sua obra intitulada "A Riqueza das Nações": Publicada em 1776, a obra é uma investigação acerca da natureza e das causas das riqueza das nações, um tratado sobre questões econômicas que vão desde as leis do mercado e aspectos monetários, até a distribuição do rendimento da terra, concluindo com um conjunto de recomendações políticas, suas teorias serviram como fonte dos paradigmas teóricos sobre os quais foi construída a Economia Política Clássica. (FRITSCH, 1996).

Adam Smith procurou demonstrar que a riqueza das nações, - 
diferentemente do que pregavam os mercantilistas de sua época - não seria determinada pela quantidade de dinheiro / moeda que esta possuía, mas a verdadeira riqueza de uma nação provém do trabalho e do fluxo de mercadorias e serviços que este produz.

"Para ele a riqueza de uma nação é identificada com seu produto anual per capita: considerando não só o uso dos recursos naturais disponíveis, mas é determinada a partir da produtividade do trabalho "útil" ou produtivo" (que pode ser entendido como aquele que produz um excedente de valor sobre seu custo de reprodução) e pela relação entre o número de trabalhadores empregados produtivamente e a população total de uma nação.

Em suas formulações teóricas, Smith estabelece que a capacidade nacional de produzir seja baseada na divisão do trabalho e na acumulação de capital; proclamava que a riqueza não advém somente de heranças, como pensavam os aristocratas, mas que ela poderia ser produzida, e, não somente pela agricultura, mas também por uma "nova" atividade, a recente indústria.

O autor atribuía explicitamente maior importância á produtividade do trabalho "útil", como fator causal do crescimento, pois para ele a riqueza, resultava de indivíduos que, movidos pelo seu próprio interesse, promoviam tal crescimento:

Não é da benevolência do padeiro, do açougueiro ou do cervejeiro que eu espero que saia o meu jantar, mas sim do empenho deles em promover seu auto interesse. Dirigimo-nos não á sua generosidade, mas ao seu amor próprio, pois nunca os comovemos pelas nossas necessidades, mas pelas vantagens que eles lograrão. (SMITH, 1996, p.60).

A teoria apresentada em "A Riqueza das Nações" é essencialmente uma "teoria do crescimento econômico" (FRISTSCH, 1996), para Smith, é a partir do interesse e da busca individual de cada pessoa que uma nação enriqueceria - daí pode se depreender o caráter individualista - já em seu cerne - do capitalismo.

Os recursos de capital das nações aumentariam quando as pessoas poupassem o excedente de seu trabalho, com o objetivo de melhorar a qualidade de suas vidas, a partir da premissa de que esse capital seria empregado da melhor forma possível na produção de mercadorias para serem trocadas no livre mercado. (FUSFELD, 2003). 
Em sua visão harmônica do mundo real, Smith acreditava que se os agentes privados (burguesia) atuassem livremente - sem a intervenção do Estado como era no contexto do absolutismo e mercantilismo - os mercados seriam regidos como se por uma "mão invisível", que os regularia automaticamente, de forma tal que não haveria necessidade de o Estado atuar, levando a economia á um estado de equilíbrio e a sociedade á um estado de perfeição.

$\mathrm{Na}$ sua concepção, ao Estado caberia desempenhar as funções da "manutenção da segurança militar", a "administração da justiça" e "prover a infraestrutura na qual as pessoas não tivessem interesses em investir" (SMITH, 1996), como na educação, redes de comunicação, estradas, todavia acreditava que se houvesse interesse pelos agentes privados, tais estruturas e serviços poderiam ser providos também por eles.

Em suas preocupações estava presente não só entender o "processo produtivo" e o crescimento da economia de uma nação, mas lhe interessava depreender da realidade, a razão do crescimento do produto social. Para ele a causa deste fenômeno tinha como raiz os progressos na divisão do trabalho, que tinham como benéfices, o aumento da destreza e invenção de máquinas e técnicas que facilitariam e abreviariam este. O princípio que dá origem á divisão do trabalho segundo Smith (1996, p.65) advém "da propensão existente na natureza humana a intercambiar, trocar uma coisa pela outra“.

A divisão do trabalho, segundo ele, determina 0 aumento da produtividade, logo determinaria também o tamanho do mercado. Furtado (1986) critica essa tese e a entende enquanto um "círculo vicioso", em que o "tamanho do mercado depende do nível de produtividade, e este da divisão do trabalho, a qual por sua vez depende do tamanho do mercado". Ora "se o aumento de produtividade resultava da divisão do trabalho, era ao trabalho que ele devia ser atribuído, e não ao capital" (FURTADO, 1986, p.8), como proposto por Smith.

Quanto ao valor da mercadoria, para o autor, nas sociedades primitivas este é determinado pela quantidade de trabalho necessário em sua produção, mas quando considerado em sociedades em que vigore a propriedade privada, o valor dessa mercadoria passa a embutir os custos da produção, estes que seriam compostos por: pagamento dos salários aos trabalhadores, os lucros de capital, e a renda fundiária.

A máxima da lei de mercado é também uma reflexão de Smith, e dispõe 
que: quanto menor a oferta, maior o preço do produto, e quanto maior a oferta, menor o preço no mercado, ou seja, ele pregava que quanto menor a quantidade ofertada de um produto no mercado, maior seria seu preço (devido á escassez deste), e quanto maior a quantidade ofertada desse produto, menor seria seu preço no mercado (devido á abundância deste); esta é uma "lei" predominante na economia até os dias atuais.

As formulações teóricas de Adam Smith não tem como preocupação central a justiça social e nem a distribuição de renda, suas preocupações centrais eram com o crescimento e progresso econômico das nações. Para ele, o progresso advém dos interesses individuais de enriquecer, que acompanhados da divisão do trabalho e ampliação dos mercados, resultam em crescimento da produtividade e um acúmulo de capital, (gerando a riqueza) em sua visão, esse processo proporcionaria bem estar ás pessoas e beneficiaria a sociedade como um todo.

Dessa visão se pode depreender certa simplificação quanto á estrutura e funcionamento do processo produtivo - da acumulação de capital propriamente dita- por parte de Smith (embora ele tratasse da acumulação de capital), que "limitava se a descrever externamente esse processo, sem perceber suas vinculações íntimas com o progresso técnico e com 0 aumento da produtividade". (FURTADO, 1986, p.10).

Contudo, essa visão "perfeita" do processo produtivo que levaria à "sociedade perfeita", porventura advenha da negação do próprio contexto político e econômico do qual Smith estudara, criticava e do qual vivenciava - a crise do absolutismo/mercantilismo e a transição para a fase inicial do capitalismo industrial, no período pré-Revolução Industrial.

As doutrinas de Adam Smith exerceram uma rápida e intensa influência na burguesia (comerciantes, industriais e financistas) do início do século XIX, pois estes queriam acabar com os direitos feudais e com o mercantilismo - uma vez que estas práticas já não atendiam ás necessidades do capitalismo emergente.

A ideia smithiana da defesa do mercado como regulador das decisões econômicas de uma nação - independente da ação do Estado - a qual traria benefícios para a coletividade é o princípio do liberalismo econômico, que dominou por quase um século o pensamento econômico, e teve como principais seguidores Thomas Malthus, Jean Baptiste Say, David Ricardo, John Stuart Mill 
entre outros que contribuíram para que se perpetuasse o laissez faire - como também era denominado o liberalismo econômico.

Esses pensadores da economia clássica, da primeira metade do século XIX, baseados em alguns postulados de Smith, seguiram suas reflexões considerando a terra, o trabalho e o capital como elementos da produção e alguns atribuíam ao trabalho a origem de todo o "valor", porém a quantidade de trabalho que podia ser empregado estava determinada pelo montante de capital acumulado, implicitamente essa teoria estabelecia que o nível dos salários reais dependeria da oferta de trabalho e da capacidade de emprego da economia, logo, não poderia ser modificado pela intervenção do governo ou de sindicatos. A capacidade de emprego era determinada por sua vez pela acumulação de capital. Esses economistas ingleses, segundo Furtado (1986) ao "estudarem a acumulação de capital, o fizeram para justificar a forma como se repartia a renda social e não com o intuito de explicar o desenvolvimento". Essa conclusão, segundo Furtado (1986), a que chegaram esses teóricos partia de dois axiomas: "o princípio da população"1 de Thomas Malthus, e a "lei dos rendimentos decrescentes"2 de David Ricardo.

A sociedade inglesa a qual esses pensadores economistas vivenciaram, era composta por homens do campo, capitalistas e os proprietários de terra, que desenvolviam cada qual o seu papel: os homens do campo trabalhavam a terra, os capitalistas produziam em suas fábricas, e os proprietários de terras, viviam da produção agrícola e do arrendamento de suas terras.

Todavia Ricardo vivencia o processo de transformação dessa sociedade em sua forma mais intensa, que tem origem com a completude da que ficara conhecida como Primeira Revolução Industrial.

\footnotetext{
${ }^{1}$ A teoria da população de Malthus consistia na conclusão de que a produção de alimentos só cresce em progressão aritmética, enquanto a população tem a tendência de aumentar em progressão geométrica, dada essa diferença em proporcionalidade, a consequência inevitável, segundo Malthus, seria uma crescente miséria das grandes massas de população, e quando a pobreza chega aos extremos, a própria natureza intervém, corrigindo-os por meio de guerras, epidemias, etc., contudo, o teórico postulava que não deveria se esperar essas catástrofes, para tal, propunha intervenções: negar às populações toda e qualquer assistência (hospitais, asilos, etc.) e aconselhar-lhes a abstinência sexual para diminuir a natalidade. A origem dessas ideias de Malthus é, em parte, econômica, em parte, religiosa.

${ }^{2}$ É uma teoria que expressa a relação económica da utilização de unidades adicionais de trabalho. Também conhecida por lei das proporções variáveis ou lei da produtividade marginal decrescente, esta lei afirma que, em todos os processos produtivos, se a quantidade de um bem for aumentada e a quantidade dos outros bens permanecer constante, a produção total por bem irá cair.
} 
Entre os anos de 1760 e 1840, o Estado Inglês estabelece a "lei de cercamento" que definia ser obrigatório o cercamento das terras, momento que a ideia de propriedade privada ganha maior robustez. Os camponeses que viviam em terras comuns a todos, gozando de seus direitos de cultivo da terra, bem como da caça e uso dos recursos naturais, sem condições para cumprir tal lei, foram forçados a migrar para os centros urbanos, uma vez que estes não dispunham nem de terra e nem de maquinários, apenas sua força de trabalho, que a vendiam para sobreviver - sob penosas condições e ganhando muitas vezes o estritamente necessário para sobreviver (HOLANDA, 1996).

A colocação em prática dessa lei privilegiava os proprietários de terra, que passaram a possuir maior quantidade de terras - uma vez que tinham condições de cumprir tal lei - e implementaram novas técnicas de cultivo que aumentaram a produção agrícola, passando a dispensar uma grande quantidade de trabalhadores do campo.

Com a migração dos camponeses para os centros urbanos, os capitalistas também foram favorecidos, devido à quantidade de pessoas que ofereciam sua força de trabalho para laborar em suas fábricas. O aumento da produção (em razão do labor dos muitos camponeses e suas mulheres e filhos, que agora se tornam trabalhadores, e, ao maquinário empregado), permitiu ao capitalista que este expandisse seus mercados e acumulasse capital.

Esses trabalhadores viviam em uma situação de miséria extrema, trabalhavam por horas a fio. As máquinas marcavam o ritmo de trabalho e suas atividades eram repetitivas, os trabalhadores perdiam de vista o produto de seu trabalho e se convertiam em mais uma engrenagem do sistema, como pode se depreender no filme clássico de Charles Chaplin (1936), intitulado de Tempos Modernos; embora o filme tenha sido produzido em uma época posterior à realidade em que Ricardo elaborara as suas teorias, este guarda aspectos muito semelhantes com o contexto de Ricardo, pois trata das condições alienantes de trabalho do período da industrialização.

Os trabalhadores - denominados por Marx também de proletários - além de viverem em situações de subsistência, careciam de uma legislação que os amparasse, tal "transformação radical nos modos de vida não deixaria de produzir muitas revoltas e agitação social entre os trabalhadores ingleses" (HOLANDA, 1996, p.7). 
É nesse contexto conturbado de transformações econômicas e sociais na Inglaterra - e cabe ressaltar de transformações políticas na França com a Revolução Francesa, que reverberavam nas ideias dos pensadores da época que Ricardo elabora suas teorias. Os interesses de David Ricardo estão voltados para a compreensão da problemática da economia política, que para ele diferentemente de Smith - esta estava centrada na distribuição da renda.

O problema central, segundo ele, estaria em: determinar as "leis que regem a distribuição do produto total da terra entre as três classes, o proprietário da terra, o dono do capital necessário para seu cultivo, e, os trabalhadores (...)". (RICARDO, 1996, p.36) - pode se depreender dessa reflexão a percepção da estratificação social, a qual será profundamente abordada posteriormente nas reflexões de Karl Marx em sua teoria "d'O Capital".

A partir da formulação teórica da renda da terra - esboçada em seu texto "Um Ensaio Sobre a Influência do Baixo Preço do Trigo Sobre os Lucros do Capital", publicado em 1815 - David Ricardo critica o Estado e a lei inglesa denominada de "Corn Laws", uma medida protecionista que restringia a importação de produtos agrícolas, Ricardo demonstrava que a proteção aos produtores nacionais de cereais menos eficientes, fazia aumentar a proporção da renda da terra e dos salários em relação aos lucros. (HOLANDA, 1996, p.8).

Essas reflexões foram a base argumentativa que David Ricardo elaborou e utilizou para a defesa da livre importação, e, foram também a base para a elaboração de sua obra intitulada de "Princípios de Economia Política e Tributação".

Para explicar sua teoria de distribuição da renda, em seu livro "Princípios de Economia Política e Tributação" - sua principal contribuição á teoria da economia política, publicada em 1817 - Ricardo valeu se das observações da produção agrícola, pois para ele, existiam aí características especiais que levavam a determinar a distribuição nos outros setores, como o industrial - uma vez que ele vivenciava a força da Revolução Industrial, com desenvolvimento da fábrica e da produção maquinizada, momento este em que o capitalismo se consolida e se impõe sobre os vestígios do regime feudal.

O esquema elaborado por Ricardo para explicar tal teoria, determinava que os salários devessem ser fixados no mínimo possível garantindo somente a 
sobrevivência dos trabalhadores, neste sentido, Ricardo apoiava se na teoria Malthusiana, para justificar seu posicionamento.

$\mathrm{Na}$ concepção de Ricardo, se fossem elevados os salários dos trabalhadores, estes melhorariam de vida, o que induziria ao aparecimento de um número maior de trabalhadores - devido a um aumento do número de filhos desses trabalhadores -, ou seja, um aumento da população.

O aumento da população acarretaria uma maior demanda por alimentos, estes que cada vez mais seriam cultivados em terras menos férteis e longínquas, (uma vez que não haveria terras férteis suficientes para atender a tal demanda), que por sua vez elevariam os preços destes - ocasionado pelo aumento dos custos de produção.

À medida que os preços dos alimentos aumentassem, os donos da terra aufeririam uma renda maior da terra, e, os capitalistas tanto quanto os trabalhadores, seriam prejudicados com o aumento dos salários, pois aumentariam o custo da produção e obteriam menores lucros.

De acordo com Furtado (1986), com esse modelo, Ricardo estabelecia os princípios de que:

(...) a elevação dos salários pressupunha uma acumulação de capital, não podendo ser feita esta em detrimento dos lucros dos capitalistas, e, o de que a classe de proprietários de terras constituía um peso social crescente, o qual somente poderia ser reduzido por meio de uma política de livre importação dos produtos agrícolas. (FURTADO, 1986, p.9).

Pode se denotar dessa reflexão de Ricardo, seu posicionamento enquanto defensor dos interesses dos capitalistas.

Ricardo vislumbrava que o processo de desenvolvimento de uma nação seria lento e gradual, atingindo a estagnação quando a população fosse numerosa, as terras cultivadas seriam extensas, a indústria seria desenvolvida e a produção seria alta. A insuficiência da acumulação de capital e de poupança apenas reporia o capital na indústria, mas não teria condições de expandi-la.

As teorias de Ricardo sobre trabalho e população, compartilhada com Malthus, também apresentam suas raízes no pensamento de Adam Smith e podem ser percebidas na afirmativa de que a expansão da produção aumentaria a oferta de emprego, logo, os habitantes de determinada nação se multiplicariam rapidamente além do necessário para atender à demanda por trabalhadores. 
E, como causa segundo Smith (1996):

(...) originará, portanto, falta emprego e levará os trabalhadores a competirem entre si, a fim de conseguirem arranjar qualquer atividade remunerada. Se num dado país os salários foram alguma vez superiores aos necessários para garantir a subsistência do trabalhador e para Ihe permitir manter uma família, a competição entre os trabalhadores e o interesse dos padrões em breve reduzi-los-ão ao seu mais baixo índice, compatível ao da maioria da humanidade. (SMITH, 1996, p. 60).

Para Smith, o salário de subsistência pago aos trabalhadores, era determinante das precárias condições de vida dos mesmos; para ele, esse era encarado como um sintoma natural de um estado estacionário de crescimento e apontava a mortalidade alta como um índice indicativo de que o país estaria em regressão.

A preocupação dos economistas clássicos girava em torno da produção e das consequências da acumulação de capital, nas quais não se discutiam se as condições de vida dos trabalhadores - atores passivos do desenvolvimento econômico para essa concepção - deveriam ser consideradas.

O pensamento liberal da economia clássica está imbuído de uma concepção filosófica e antropocêntrica, em que coloca o indivíduo no centro do universo, capaz de discernimento e racionalização de suas ações pelo seu bem individual, que acarretará o bem comum. Nessa visão de sociedade, não há conflito, o mundo é das liberdades: livre-iniciativa, livre-arbítrio, livre-mercado.

A teoria destoante do pensamento da economia clássica será a de Karl Marx, que partindo de uma posição filosófica e crítica em face da história, elaborou sua teoria social sobre o capitalismo, marcada por muitas polêmicas até os dias atuais, que partem tanto de motivações científicas quanto de recusas ideológicas, afinal, segundo Paulo Netto (2011, p.11) "Marx nunca foi um obediente servidor da ordem burguesa (...)".

Karl Marx (1818-1883) nascera em Trier, localizada na Renânia, então província da Prússia, limítrofe da França, e por isso, incisivamente influenciada pela Revolução Francesa e pelos pensamentos iluministas, sobretudo nas camadas cultas da sociedade - a qual seu pai, um advogado de baixo escalão do governo e sua família faziam parte. Trier era uma das partes mais desenvolvidas da - atual - Alemanha, devido ao estabelecimento de núcleos da então moderna indústria fabril, em torno da qual se polarizavam as duas novas 
classes da sociedade capitalista: o proletário e a burguesia, esta era a circunstância social a que Marx vivenciara e que o influenciara em sua vida.

Em 1830, Marx iniciou seus estudos - ano em que eclodiram revoluções em diversos países europeus - ingressou mais tarde na Universidade de Bonn para estudar Direito, transferindo-se no ano seguinte para a Universidade de Berlim. Sua oposição aos governos autocráticos da Alemanha, o impediu de seguir carreira em Direito, fazendo com que seus interesses se voltassem para a Filosofia, formação que teve influência espiritual, e firmou ser um dos eixos de sua produção intelectual ao longo de sua vida, embora não tenha prosseguido na carreira universitária - a qual era seu objetivo quando do interesse em Filosofia. $O$ jovem Marx passou então a dedicar se ao jornalismo, tornando se editor de um jornal em 1842.

Embora a trajetória teórica de Marx tenha se iniciado em 1841, ao receber o título de doutor em Filosofia, é entre os anos de 1843 e 1844, "quando se defronta polemicamente com a filosofia de Hegel, sob influência materialista de Feuerbach, que ele começa a revelar o seu perfil de pensador original" (PAULO NETTO, 2011, p.16), os textos intitulados Para a questão judaica; Crítica da filosofia do direito de Hegel e Introdução foram elaborados nessa época.

Marx direciona suas pesquisas para a análise concreta da sociedade moderna - a sociedade burguesa - a partir do estímulo provocado pelas formulações de Engels acerca da economia política, de forma que pode se circunscrever, segundo Paulo Netto (2011), como o "problema central da pesquisa marxiana a gênese, a consolidação, o desenvolvimento e as condições de crise da sociedade burguesa, fundada no modo de produção capitalista" (PAULO NETTO, 2011, p.17), sendo seu objetivo descobrir a estrutura e a dinâmica da sociedade burguesa, saindo do campo da aparência para o campo da essência, considerando todas as contradições que lhe são intrínsecas.

É a partir dessa pesquisa, que resultarão as bases da teoria social de Marx, que o ocupará pelo resto de sua vida, tendo como início com os Manuscritos econômico-filosóficos de 1844 e a sua culminação nos materiais que constituem 0 Capital. Pode se depreender da longa bagagem de vida, atuação política, e do processo intelectual de Marx - que tinha como base a filosofia (sobretudo a alemã), a economia política clássica e o socialismo utópico (sobretudo francês) que ele não fazia tábula rasa do conhecimento existente, mas partiu criticamente 
dele, e o que Marx fez n'O Capital, de acordo com Harvey: "combina tradições intelectuais divergentes para criar uma estrutura completamente nova e revolucionária do conhecimento" (HARVEY, 2012, p.14); friccionando o materialismo, o conhecimento histórico e a dialética, dissecando, descontruindo e construindo novos conhecimentos, método e teoria, considerada por alguns autores como a grande contribuição de Marx.

Árdua é a tarefa de se condensar o grande esquema de pensamento de Marx e sua teoria d'O Capital, sem se cometer uma injustiça com o poder e a consistência de seu raciocínio, entretanto, é importante que haja um esforço para a compreensão de sua teoria - embora seja extensa e complexa -, "ao menos porque se trata da base de uma das mais poderosas ideologias do mundo moderno" (FUSFELD, 2003, p.83).

Para Marx, as relações econômicas são as forças motrizes fundamentais em qualquer sociedade, de qualquer época; para ele:

(...) na produção social que os homens realizam, eles estabelecem relações definidas, que são necessárias e independentes de sua vontade; essas relações de produção correspondem a uma etapa determinada no desenvolvimento das suas forças produtivas materiais. $A$ totalidade dessasrelações de produção forma a estrutura econômica da sociedadea verdadeira base sobre a qual se ergue uma superestrutura jurídica $e$ política, e à qual correspondem formas definidas de consciência social. 0 modo de produção da vida material condiciona o caráter geral do processo social, político e espiritual da vida. (MARX, 2008, p.47. grifo nosso).

Segundo Marx os dois grandes interesses econômicos em uma sociedade capitalista são: os do capitalista e os do trabalhador, classes que se opõem uma á outra, uma vez que o capitalista só poderá prosperar se o trabalhador for explorado, Marx chega a essa conclusão após mergulhar na história das sociedades (desde a dissolução do regime primitivo da propriedade comum da terra) e se deparar com a seguinte realidade:

A história de todas as sociedades existentes até os nossos dias, tem sido a história da luta de classes. Homem livre ou escravo, patrício ou plebeu, mestre de corporação e companheiro, numa palavra, opressores e oprimidos, numa permanente oposição (...). A sociedade burguesa moderna, que emergiu das ruínas da sociedade feudal, não aboliu os antagonismos de classe. Nada fez senão substituir novas classes, novas condições de opressão, novas formas de luta às que existiam no passado. (MARX e ENGELS, 1987, p.27-28). 
Com suas elaborações teóricas ao longo de muitos anos, Marx buscou identificar quais eram as relações de produção fundamentais do sistema capitalista e quais seriam os fatores que atuariam na superação desse regime, uma vez, que em sua visão devido às constantes crises intrínsecas tanto da estrutura, quanto da dinâmica desse sistema, ele um dia viria a sucumbir.

Marx contrapõe se ao pensamento naturalista dos economistas clássicos, uma vez que para ele o surgimento do sistema capitalista ocorre em função de um processo histórico que culminou em relações econômicas propícias a essas relações de produção e troca. O ponto de partida é que a produtividade do trabalho não seria um acaso da natureza, mas consequência da história construída ao longo de milhares de séculos.

As características naturais do capitalismo estão no que concerne à disponibilidade de recursos naturais como: água, minérios, navegabilidade dos rios entre outros; às condições climáticas, e às condições físicas do homem.

Para ele é a necessidade do homem de controlar socialmente uma força natural, podendo então utilizá-la e dominá-la pela realização de obras, que desempenha o papel decisivo na história do surgimento da indústria.

Compreendendo a teoria do valor-trabalho enquanto indispensável para a análise das relações de produção do regime capitalista, Marx reconhece nela embora diferentemente da perspectiva dos economistas de outrora que a elaboraram -, "o fundamento da doutrina da mais-valia, que em última instância, é a anatomia da luta de classes no regime capitalista". (FURTADO, 1986, p.15).

Para Marx a mais-valia consiste na apropriação pelo capitalista de uma determinada quantidade de trabalho não pago, ao trabalhador, ou seja, é aquilo que o trabalhador produz a mais em relação ao que ganhará pela produção, Marx considerava que esta seria a base do lucro no sistema capitalista. "A exploração do trabalhador pode ser intensificada, e a mais-valia apropriada pelo capitalista, aumentada, por meio de esforços do empregador em diminuir os salários, aumentar as jornadas e contratar uma quantidade de mulheres e crianças" (FUSFELD, 2003, p. 84), essa seria a exploração de ordem física e econômica do trabalhador, em que transformava a mais-valia em capital para o capitalista, servindo assim á auto- expansão do sistema.

A produção para Marx é encarada essencialmente como produção de mais- valia. $O$ trabalho produtivo não é apenas uma relação entre a atividade de 
produção e seu efeito útil, entre trabalhador e produto, mas acima de tudo, uma relação social, com origem histórica em que 0 trabalhador torna se 0 instrumento de criação da mais-valia.

A mais-valia absoluta se realiza com o prolongamento da jornada de trabalho além do ponto em que o trabalhador produz apenas um equivalente ao valor de sua força de trabalho e com a apropriação pelo capital desse trabalho excedente. Ela constitui o fundamento do sistema capitalista. (MARX, 2001, p.578).

Em suas investigações Marx também evidenciara a exploração de ordem psicológica, o teórico entendia o trabalho "Como criador de valores de uso, como trabalho útil, (...) por isso, uma condição de existência do homem, (...) eterna necessidade natural de mediação do metabolismo entre homem e natureza”. (MARX, 2001, p.50), logo, a completa realização pessoal pressupunha um desenvolvimento rico e pleno das relações dos indivíduos com os meios de produção e o produto de seu trabalho. Entretanto, no capitalismo o que é evidenciado por Marx, é que o trabalhador é separado tanto de seus meios de produção, como dos produtos de seu trabalho - estes que são pertencentes ao empregador capitalista. A consequência dessa dinâmica é a alienação, que se apodera dos trabalhadores e desumaniza todas as relações pessoais e sociais, culminando em diversas patologias sociais e psicológicas que permeiam a sociedade capitalista.

Exploração e alienação são uma das faces do capitalismo, a outra é a acumulação de capital e o crescimento da riqueza (FUSFELD, 2003, p.84), essas evidencias levaram Marx a identificar claramente a desigualdade social que é gerada pelo crescimento econômico do capitalismo, que posteriormente será tratado principalmente pelos economistas como sinônimo de desenvolvimento.

A concepção de desenvolvimento, como sinônimo de crescimento e progresso, permeou as formulações teóricas e o senso comum por muito tempo. Embora esses termos possuam fortes vínculos, não significa que sejam sinônimos.

$\mathrm{Na}$ perspectiva de Morin (2000) a ideia de desenvolvimento continua ainda tragicamente subdesenvolvida porque presa à racionalidade econômica, para ele: 
O desenvolvimento é a palavra chave, tornada onusiana, em torno do qual se debateram todas as vulgatas ideológicas da segunda metade do nosso século. No fundamento da ideia dominante de desenvolvimento está o paradigma ocidental do progresso. O desenvolvimento deve assegurar o progresso, o qual deve assegurar o desenvolvimento. (MORIN, 2000 p.78. grifo nosso).

O termo progresso de acordo com Sztompka (1998) teria suas origens na Idade Antiga, perdurado e ganho importância ao longo dos tempos por corresponder a uma característica da condição humana de necessidade de preencher um hiato "entre a realidade e as aspirações, a existência e os sonhos". (SZTOMPKA, 1998, p.97).

Desde então a ideia de progresso fora ganhando peso lentamente e se materializando a partir do século $X$ com o processo de mecanização; de acordo com De Masi (1999) "entre os séculos X e XIII chega o progresso tecnológico e com ele a substituição de muitos dos trabalhos do homem pelo trabalho mecânico" (DE MASI, 1999, p.10). Com o aumento da população e inovações técnicas, sobretudo na agricultura, nos transportes e na comunicação, são produzidos cada vez mais excedentes agrícolas, que passam a ser trocados comercialmente, liberando uma parte da população que se desloca para outras atividades econômicas não vinculadas á terra: o artesanato e o comércio, e, que provocaram o êxodo rural da população, o que resultou no (re) surgimento das cidades e do comércio.

Subsequente a esse período, com as ideias renascentistas, sobretudo ás científicas - que permitiram o avanço tecnológico, como a descoberta da bússola, astrolábio, entre outros - foram essenciais para a viabilização das expansões marítimas dos séculos XV e XVII e a formação dos Estados Nacionais, como Portugal e Espanha, a colonização das Américas, Índias e África possibilitaram a "conquista" e a exploração de novas riquezas além de uma grande quantidade de terras a serem cultivadas. Para tal "conquista" as potências europeias valeram se do resgate de uma das formas mais aviltantes de trabalho já adotada pela humanidade: a escravidão, justificada como necessária, sob o manto da filantropia, uma vez que este seria um favor que os civilizados - europeus fariam aos bárbaros - as populações autóctones, de os apresentarem a um mundo evoluído, justificativa essa que inclusive era legitimada e apoiada pela Igreja Católica. 
A escravidão negra e indígena foi fundamental no processo de acumulação de capital, conhecido como capitalismo comercial, possibilitando o lucro, na comercialização da mão de obra e em sua utilização como trabalho produtivo na monocultura que sustentava o pacto colonial, praticado na relação comercial entre metrópoles e colônias. Para Furtado é a "partir dos recursos que foram apropriados por meio da escravidão que constituíram o ponto de partida do processo acumulativo". (FURTADO, 1986, p.146).

No século XIX, o conceito de progresso atingiu seu ápice, assumindo o caráter de necessidade, em que sua realização material seria uma condição necessária para que as pessoas comuns pudessem superar seu destino de danação social. Este século é preeminentemente marcado pela prática do liberalismo, em que o Estado praticamente não intervia na economia, estando a seu cargo a administração da justiça, diplomacia, e, incipientemente a educação.

O conceito de desenvolvimento entendido na acepção de evolução advém da biologia, pelas teorias elaboradas por Charles Darwin, cientista britânico que por volta da segunda metade do século XIX, publica sua obra "A Origem das espécies", e, funda as bases da teoria da evolução, com seu conceito do desenvolvimento de todas as formas de vida por meio de um processo lento denominado de seleção natural ${ }^{3}$.

A teoria da evolução de Darwin teve tamanho impacto e importância que encontrou eco nas diferentes áreas do conhecimento, influenciando as $e$ revolucionando as; com as ciências sociais não foi diferente, no contexto de um paradigma positivista, alguns pensadores sociais decidem aplicar os conceitos e conclusões darwinianas à ordem social, surgindo desse pensamento a corrente denominada de "darwinismo social".

\footnotetext{
${ }^{3}$ Seleção Natural é um termo criado para explicar como as espécies de animais e plantas se modificam e evoluem. Essa teoria define que os seres vivos que existem hoje são descendentes de outros que viveram em um passado muito distante e que teriam evoluído para se adaptar às modificações do ambiente. Como cada animal tem uma ligeira variação em relação aos demais de sua espécie, sobrevive quem tem alguma vantagem sobre a concorrência, na competição pela sobrevivência e reprodução; porém essa vantagem não necessariamente é ser o mais forte, pode ser o mais rápido, mais forte, o maior, mas nem sempre é este o caso. Este é um equívoco cometido por muitos cientistas que deturparam a ideia de Darwin.
} 
A teoria do darwinismo social - que valeu se das teorias de Hebert Spencer ${ }^{4}$ como fundamento - pode ser definida como a transposição da teoria da evolução e seleção natural ás ciências sociais, com o intuito de explicar a sociedade e suas práticas sociais. A tese era de que, igualmente às espécies de seres vivos, também as pessoas e as sociedades seguiriam a mesma lógica: a de que existiriam características biológicas e sociais nos indivíduos, que determinariam as vantagens que possuiriam em relação aos demais, estas, definiriam a "sobrevivência do mais apto". "A vida na sociedade humana é uma luta natural pela vida, portanto, é normal que os mais aptos a vençam, da mesma forma que os menos aptos fracassem" (BOLSANELLO, 1996), consequentemente, os mais aptos teriam a facilidade em se adaptar às dinâmicas sociais e se desenvolver, passando de um estágio inferior de evolução a um estágio superior, portanto, isso explicaria por que algumas sociedades seriam mais "desenvolvidas" do que outras, pois eram dotadas de valores e capacidades que as colocavam em condição superior ás demais.

A ampliação do uso dessa teoria tiveram consequências negativas para a humanidade, pois esta serviu em certa medida de base para as ideologias do racismo e da eugenia, uma dessas consequências foi o genocídio dos judeus na Alemanha.

O termo desenvolvimento passa a ser difundido em escala mundial após a II Guerra Mundial - por volta das décadas de 1950 e 1960 - atrelado ao termo subdesenvolvimento. Dessa forma 0 mundo se polarizava em países "desenvolvidos" - sendo enquadrados nesta categoria os países com uma economia industrial, com maior concentração da população em área urbana, estes localizados na Europa e em alguns territórios asiáticos -, e, países "subdesenvolvidos" - aqueles com economia "primária", baseada na agropecuária e na exportação de matérias primas, localizados geograficamente em sua maioria no polo Sul, nos continentes da África, parte da Ásia, Américas Central e do Sul, e, também no Oriente Médio.

No caminhar da teoria do desenvolvimento, acreditou se que ou o

\footnotetext{
${ }^{4}$ Herbert Spencer foi um filósofo, suas teorias se desenvolveram no campo da engenharia, filosofia e educação. Existem divergências de opiniões entre teóricos acerca de que Herbert Spencer tenha sido de fato o mentor do darwinismo social. "O nome de Herbert Spencer fica na História da Filosofia, ainda que no testemunho de poucos autores, intimamente ligado ao que ficou conhecido como darwinismo social". (BAIARD, 2008).
} 
socialismo ou o capitalismo eram seus verdadeiros agentes, e cada um, para seus adeptos foi dotado de um gênio providencial, cada qual a sua maneira: o capitalismo com uma fórmula de organização econômica, baseada no mercado e na economia privada; e, o socialismo, com uma planificação e economia de Estado, estas duas fórmulas pretenderam garantir o desenvolvimento social e humano.

Entretanto, o que pode se depreender da realidade é que tanto "O socialismo [quanto] o capitalismo foram, em suma, mitos do desenvolvimento". (MORIN, 1995, p.103):

O primeiro, em sua versão soviética, está moribundo, e, em sua
versão social democrata, chegou ao esgotamento. O segundo goza
apenas de uma saúde aparente. Foi apenas por um tempo muito curto
que ele se mostrou como a fórmula mágica para resolver todos os
problemas. As noções de socialismo e de capitalismo não podem ser
concebidas como noções providencialistas, imperialistas e redutoras.
Mas se considerarmos a energia e a invenção econômica do capitalismo
e as qualidades autorreguladoras e auto-organizadoras do mercado, tanto
umas como outras devem ser integradas à civilização planetária e não
esta integrada ao capitalismo ou ao mercado. Tudo o que é somente
econômico, como tudo o que é somente tecnológico, é bárbaro e
civilizador na mesma proporção e deve ser integrado e subordinado a
uma política do homem. (MORIN, 1995, p.103- 104).

Com a falência do socialismo, o modelo ocidental - capitalista - teria experimentado seus anos de glória, com o modelo fordista no mundo ocidental - apesar das intrínsecas crises - e ao final do século XIX e início do século $\mathrm{XX}$, o modo de produção capitalista industrial, transformou novamente as formas de produção e de trabalho, alterando profundamente a configuração e as relações sociais.

De acordo com Harvey (2012), a visão de Ford consistia no reconhecimento explícito de que a produção de massa significava também um consumo de massa, um novo sistema de reprodução do trabalho, um novo tipo de sociedade, esta que poderia ser construída com a aplicação adequada ao poder corporativo de regulamentação da economia.

Para Ford a jornada de trabalho de 8 horas a cinco dólares tinha como propósito, segundo Harvey (2012), não só disciplinar os trabalhadores ao sistema de linha de montagem de alta produtividade, mas também dar aos trabalhadores renda e tempo de lazer suficiente, para que consumissem os produtos produzidos em massa, fabricados em quantidades maiores. 
O sistema de produção fordista era rotinizado, exigindo pouco das habilidades manuais tradicionais, uma vez que era desenvolvido com diferentes tecnologias, que concediam pouco controle por parte do trabalhador sobre a organização do processo produtivo.

Por volta do final dos anos de 1960, o modo de produção industrial nos moldes fordistas passa a enfrentar um enfraquecimento, sobretudo nos países dito desenvolvidos - dado o contexto político-econômico á época - originando um processo de mutação do sistema estabelecido.

É a transição da "condição moderna" para a "condição pós-moderna"; do capitalismo industrial para o capitalismo financeiro.

Essa transição é caracterizada em uma reorientação produtiva á qual David Harvey denomina de "acumulação flexível", pois o caráter "rígido" da produção nos moldes fordistas, passa a ser alterado por uma produção de caráter "flexível", que se apoia na flexibilização dos processos de trabalho, mas também dos mercados de trabalho e dos produtos e padrões de consumo. "A acumulação flexível envolve rápidas mudanças dos padrões do desenvolvimento desigual (...) entre setores, criando, por exemplo, um vasto movimento no emprego no chamado setor de serviços". (HARVEY, 2012, p.140), ou seja, os trabalhadores industriais de outrora, tornaram-se trabalhadores do setor de serviços.

Segundo Harvey, os poderes aumentados de flexibilidade e também de mobilidade do capital, permitem que os empregadores exerçam pressões cada vez mais fortes de controle do trabalho, sobre uma força de trabalho que já enfraquecida - dado o contexto de outra crise do capitalismo iniciada na metade dos anos 1970 em diante - viu o desemprego aumentar nos países capitalistas avançados da Europa e nos Estados Unidos. A acumulação flexível implica não só em níveis altos de desemprego "estrutural", mas em uma "rápida destruição e reconstrução de habilidades, ganhos modestos (quando há) de salários reais [...] e o retrocesso do poder sindical - uma das colunas políticas do regime fordista" (HARVEY, 2012, p.140), e ainda, precarização dos trabalhadores, que é traduzida em terceirização; "desregulamentação dos direitos do trabalho, que são eliminados cotidianamente em quase todas as partes do mundo onde há produção de serviços; aumento da fragmentação no interior da classe trabalhadora". (ANTUNES, 2013, p.53). 
Cabe salientar que existem diferenças nas diversas formas de desenvolvimento que o capitalismo assumiu nos continentes, regiões e países, bem como diferentes períodos na história. Enquanto na Europa o modelo fordista e o capitalismo industrial sofriam mais uma de suas crises ao final dos anos 1960, nos países ditos subdesenvolvidos, como o Brasil, a realidade era um pouco diferente, uma vez que esses países iniciavam seus processos de industrialização.

O modelo desenvolvimentista no Brasil realizou se com os ideais de Juscelino Kubitschek, que ocorreu entre 1956 e 1961, juntamente com a construção estratégica da nova capital federal - Brasília, tendo como propósito desenvolver o interior do país e promover a sua integração. O Plano de Metas de $J K$ definia os principais objetivos a serem atingidos - agrupados em cinco setores: energia, transporte, indústria, educação e alimentação - para o desenvolvimento do país, denotando a intensa intervenção do Estado na economia, a ideologia desenvolvimentista do modelo de Juscelino enfatizava o crescimento econômico do país através da atração de capitais estrangeiros e foi assim que ele viabilizou seu projeto. O modelo de desenvolvimento brasileiro da época guardava algumas particularidades que o distinguiam das demais economias latino americanas, entretanto, permaneceu preso à visão economicista, pois não fazia parte de um projeto de desenvolvimento integrado, que levasse em conta preocupações sociais como, educação, saúde, dentre outras, era um projeto de cunho setorial que encerrava se em torno de si.

No contexto mundial, o termo desenvolvimento esteve atrelado a três características: ao processo de industrialização, ao aumento da renda por habitante e ás taxas de crescimento, dentro dessa perspectiva, os aspectos políticos e sociais foram relegados pelo Estado, como a justa distribuição da renda, entre outros. Até o início dos anos de 1970, a concepção de desenvolvimento enquanto crescimento esteve relacionada ao aumento do Produto Interno Bruto (PIB) ${ }^{5}$, e a, outros índices de natureza econômica, que eram utilizados para identificar o crescimento econômico, como: o crescimento da força de trabalho, o grau de aperfeiçoamento tecnológico, dentre outros.

\footnotetext{
${ }^{5}$ O PIB - Produto Interno Bruto representa a soma - em valores monetários - de todos os bens e serviços finais produzidos numa determinada região, quer sejam países, estados, ou cidades, durante um período determinado.
} 
Embora essa concepção de desenvolvimento estivesse atrelada à industrialização, a Organização das Nações Unidas (ONU), valia se de outros indicadores para classificar os países quanto ao grau de desenvolvimento, e passa a introduzir o componente humano e social em seus levantamentos, entretanto isso ocorre somente a partir dos anos 1990. Não obstante das contribuições de Amartya Sen, entre outros pensadores, a ONU, através do Programa das Nações Unidas para o Desenvolvimento (PNUD) passa a usar uma nova forma de medir o desenvolvimento, através do conceito de Índice de Desenvolvimento Humano (IDH), o qual tem como indicadores, a média expectativa de vida, a taxa de mortalidade infantil, a média de escolaridade, dentre outros indicadores tanto nas áreas da educação, da saúde, etc., ou seja, há um avanço na concepção de desenvolvimento, incluindo indicadores que passaram a contemplar o componente humano, social.

No contexto da América Latina, a criação em 1948 da Comissão Econômica para a América Latina e Caribe (CEPAL) fora um importante passo rumo aos debates e ações sobre a questão do desenvolvimento. A CEPAL é uma comissão regional das Nações Unidas que nasceu com o objetivo de contribuir para o desenvolvimento da região, coordenando as ações encaminhadas à sua promoção, bem como reforçar as relações econômicas entre os países integrantes e entre estes e as demais nações do mundo. Avanços ocorreram desde então, quando em 1984 esta comissão incorpora como um de seus objetivos a promoção do desenvolvimento social.

A CEPAL se desenvolveu como uma escola de pensamento, composta por diversos autores - dentre eles Raul Prebisch e Celso Furtado - que criaram e desenvolveram teorias relevantes a partir do exame das tendências econômicas e sociais da região, para uma melhor compreensão das transformações da realidade latino-americana e caribenha. De acordo com Fusfeld (2003), desde os primeiros anos de sua criação, a CEPAL desenvolveu um método próprio para analisar a realidade, trata se de uma "abordagem histórico-indutiva" combinada com o "estruturalismo", sendo essa concepção "oposta à metodologia econômica tradicional, predominantemente lógico-dedutiva e a-histórica." (FUSFELD, 2003, p.291).

De acordo com Bielschowsky (2000), a evolução das ideias da CEPAL pode ser dividida em cinco períodos, caracterizados em décadas, sendo a primeira 
análise econômica e que inaugura às investigações cepalinas, a de Raul Prebisch que em 1949, elabora um diagnóstico acerca da profunda transição que ocorria nas economias subdesenvolvidas latino americanas do modelo de crescimento primário com as exportações ao modelo urbano-industrial (BIELSCHOWSKY, 2000, p.20).

Para Bielschowsky (2000), os anos 1950 são considerados o período da industrialização, marcado pela deterioração dos termos de troca; desequilíbrio estrutural na balança de pagamentos e integração regional. Quanto às condições estruturais internas, o período focava o processo de industrialização substitutiva e tendências perversas causadas pela especialização e pela heterogeneidade estrutural, tendo como consequências a inflação estrutural e o desemprego.

Os anos 1960 focam a possibilidade de reformas para viabilizar o desenvolvimento, desobstruindo a industrialização, surgindo a teoria da dependência, que trata se da integração regional, política internacional de redução da vulnerabilidade na periferia. Quanto ás condições estruturais, o enfoque dos estudos está na reforma agrária e distribuição de renda como requisitos para tornar a economia dinâmica.

Nos anos 1970, o enfoque dos estudos centra se na reorientação dos modelos de desenvolvimento na direção da homogeneização social, bem como do fortalecimento das exportações industriais. Período que foi marcado pela dependência desses países subdesenvolvidos aos desenvolvidos, causada pelo endividamento e pela insuficiência exportadora. As teorias desse período focam os estilos de crescimento, a estrutura produtiva e distributiva, bem como as estruturas de poder e a industrialização que combina o mercado interno com o esforço exportador.

Os anos 1980 são marcados por uma asfixia financeira dos países latinos americanos e caribenhos - conhecida como a década "perdida" no Brasil - em que estes se encontravam endividados com a urgência de renegociar suas dívidas para a retomada do crescimento econômico. A análise cepalina neste contexto focava o ajuste com crescimento; oposição aos choques do ajuste; necessidade de políticas de renda e eventual conveniência de choques estabilizadores, além de uma preocupação com o custo social desse ajuste.

Entre os anos 1990, até 1998 - data final da análise de Bielschowsky - 
o autor identifica a ineficiência na tentativa de especialização de exportações e a vulnerabilidade aos movimentos de capitais e em termos estruturais identificou se a dificuldade para uma transformação produtiva social eficaz, para tal superação, buscou se executar políticas para fortalecer a transformação produtiva com equidade.

O método estruturalista cepalino permeia as teorias de Celso Furtado, o qual defende a importância de se entender a questão do subdesenvolvimento a partir de um contexto histórico específico. Para ele "a análise dos processos históricos de desenvolvimento constitui ponto de partida para a compreensão das diversas formas que tomou a acumulação de capital". (FURTADO, 1986, p.144).

$O$ autor entende que o principal obstáculo ao desenvolvimento dos países subdesenvolvidos está centrado no controle das estruturas de poder, ou seja, na dominação social, bem como na apropriação e utilização do excedente advindo da acumulação de capital, por "grupos cujas motivações não se relacionam de forma principal com a atividade produtiva (...) cujos objetivos não são compatíveis com os interesses da coletividade". (FURTADO, 1986, p.144).

Recentemente outro conceito surge criando uma nova divisão - que pode ser considerado quase como um meio-termo entre países subdesenvolvidos e países desenvolvidos - a dos "países emergentes", denominados como aqueles que se encontram em fase de desenvolvimento pós-industrial, com maioria da população concentrada nas cidades. O maior exemplo de Países Emergentes está representado pelos $\mathrm{BRICS}^{6}$ (Brasil, Rússia, Índia, China e África do Sul), e outros países como o México, o Chile, dentre outros. Entretanto, pode se depreender da realidade de acordo com Heidemann (2010), que "desenvolver um país significava, e ainda significa basicamente implantar uma economia de mercado que inclua se não a totalidade, pelo menos uma parte de seus cidadãos" (HEIDEMANN, 2010, p.26), e nessa perspectiva cabe ressaltar que nesses países "emergentes", veem ocorrendo o que ocorrera com os países desenvolvidos de outrora: o atendimento à lógica capitalista, incluindo seus cidadãos na ciranda do

\footnotetext{
${ }^{6}$ BRICS é uma sigla que se refere aos países membros: Brasil, Rússia, Índia, China e África do Sul que juntos formam um grupo político de cooperação. Os membros fundadores e a África do Sul estão todos em um estágio similar de mercado emergente devido ao seu crescimento econômico. Apesar do grupo ainda não ser um bloco econômico ou uma associação de comércio formal, como no caso da União Europeia existem fortes indicadores de que os países membros têm procurado formar uma "aliança", e assim converter seu crescente poder econômico em uma maior influência geopolítica.
} 
capital, transformando cidadãos em consumidores.

Há que se ressaltar que embora os países denominados "emergentes" estejam crescendo, progredindo em termos econômicos, a realidade não é a mesma em termos político-sociais e ambientais, já que são cada vez mais evidentes nesses países, as desigualdades sociais, a corrupção, a degradação de seus recursos naturais, a não participação, ou, a participação representativa, estas que são características intrínsecas do capitalismo e do mundo pósmoderno. Neste sentido, nos alerta Boaventura de Souza Santos (2011), que as "nações (ditas democráticas), vivenciam uma "democracia liberal", pois esta vem a ser a democracia do "capital", que caminha para que as "sociedades sejam politicamente democráticas, mas socialmente fascistas".

Fato reconhecível é que ao mesmo tempo em que a tríade ciência/técnica/indústria, propiciou facilidades aos seres humanos, os tornou refém. E á medida em que o crescimento descontrolado ad infinitum, bem como a mercadorização e mercantilização de todos os aspectos da vida se estabelecem e avance, o processo democrático se fragiliza e retrocede, entretanto, é preciso considerar e reconhecer que toda evolução comporta o abandono, toda criação comporta destruição, e como nos alerta Morin (2000, p.86), "não será a qualidade técnica dos planos de desenvolvimento que evitará esta morte".

Ao longo da trajetória evolutiva do conceito de desenvolvimento, pode-se depreender e aprender com a realidade, que o desenvolvimento é um processo dinâmico de melhoria, que implica em evolução, crescimento e avanço. Para tal apreensão, vital foi a percepção da diferenciação entre crescimento e desenvolvimento: o crescimento não conduz necessariamente à igualdade nem à justiça sociais, porque sua preocupação está centrada somente no crescimento material e na geração de renda; está centrado nas questões objetivas, materiais da vida; o desenvolvimento, por sua vez, ocupa-se não só com a geração de renda, mas com a distribuição da mesma, de forma a impulsionar a melhoria da qualidade de vida, propiciando o bem estar físico, moral e espiritual de todos, ou seja, está centrado para além da materialidade, contemplando o imaterial, a subjetividade.

Embora ainda se enalteça na maioria dos estudos, pesquisas e discursos político-ideológicos, o crescimento econômico como sendo o 
fundamental no processo de desenvolvimento, (devido ao paradigma econômico ainda vigente em todas as instâncias da vida), fundamental se faz avançar nessa trajetória evolutiva, não só por uma questão ética e responsável para com a humanidade e a natureza presentes, mas também para com as gerações futuras. Neste sentido, na perspectiva de Celso Furtado (1986):

\begin{tabular}{l} 
Desenvolvimento é, principalmente, um processo de ativação e \\
canalização de forças sociais, de melhoria da capacidade associativa, de \\
exercício da iniciativa e da criatividade. Portanto, trata-se de um \\
\hline processo social e cultural com desdobramentos econômicos. O \\
desenvolvimento ocorre quando, na sociedade, se manifesta uma \\
energia capaz de canalizar, de forma convergente, forças que \\
estavam latentes ou dispersas. Uma verdadeira política de \\
desenvolvimento terá que ser a expressão das preocupações e das \\
aspirações dos grupos sociais que tomam consciência de seus \\
problemas e se empenham em resolvê-los. (FURTADO, 1986, p.36. grifo \\
nosso).
\end{tabular}

Considerando esta perspectiva os elementos intangíveis são de extrema relevância para que o desenvolvimento ocorra; além da necessidade de um novo paradigma para entender e compreender o desenvolvimento. Neste sentido alguns teóricos de diferentes áreas do conhecimento veem propondo enfoques holísticos, sistêmicos, complexos da realidade em todos os aspectos, como Edgar Morin, Fritjot Capra, Ilya Prigogine, Leonardo Boff, Humberto Maturana, entre outros, que estão por trás desse novo paradigma.

Nesta perspectiva, outro desenvolvimento que não atrelado unicamente a ideia de crescimento é possível, e, na esteira dessa busca, é reconhecível que o conceito de desenvolvimento tenha tido evoluções, sobretudo com as diversas abordagens que veem sendo exaustivamente discutidas, elaboradas e implementadas por plurais instituições em diferentes lugares da terra na busca de uma compreensão do fenômeno. As dimensões sociais e ambientais que outrora não faziam parte do debate sobre o desenvolvimento, a partir do final do século XX passam a permeá-lo e terem um peso, principalmente devido ás modificações ocorridas nos processos produtivos, que provocaram enormes desequilíbrios, principalmente sociais e ambientais.

De acordo com Boisier, o desenvolvimento é a utopia social por excelência (BOISIER, 2001, p.5), considerado essa premissa, Boisier aborda que a polissemia que se produziu em torno da concepção de desenvolvimento, talvez 
se deva graças a essa natureza utópica e em parte devido às percepções cartesianas que não abarcavam a totalidade e complexidade da realidade. Logo, acoplam-se adjetivações que criam identidade única em relação ao desenvolvimento: desenvolvimento local, desenvolvimento territorial, desenvolvimento endógeno, desenvolvimento sustentável, desenvolvimento regional, dentre outras, como uma forma de "categorização"; o que essas diferentes propostas guardam em comum é a intenção de superar qualitativamente as formas anteriores de desenvolvimento.

Embora haja essa "categorização" por parte dos teóricos do desenvolvimento, cabe ressaltar que não existem concepções claras, definitivas que delimitem e nem que determinem as fronteiras de distinções significativas entre um conceito e outro. Em diversas situações essas concepções se fundem e se confundem, no entanto, objetivando compor um entendimento sobre cada uma dessas "categorias", uma breve explanação sobre as diversas abordagens será realizada.

\subsubsection{DESENVOLVIMENTO LOCAL}

As primeiras iniciativas de desenvolvimento local de forma mais intensa, em termos práticos, surgem na Europa no início dos anos 80 e nos países da América Latina por volta dos anos 1990, como uma resposta para enfrentar as mudanças geradas pelo fenômeno da globalização, sobretudo na "Europa como uma resposta a crise macroeconômica e ao ajuste, incluindo o ajuste da política supranacional implícita na formação da União Europeia" (BOISIER, 2001, p.8). A solução encontrada pelas economias locais para enfrentar os problemas e desafios dessa dinâmica, segundo Vázquez Barquero (2001), passa pela reestruturação do sistema econômico e pelo ajuste do modelo institucional, cultural e social de cada território.

De acordo com Boisier, há considerável confusão na literatura em relação á ideia de desenvolvimento local, que segundo ele, se deve a duas causas. A primeira é por se tratar de uma "prática sem teoria" nos dizeres de Guimaraes (1997, p.281 apud Boisier); a segunda, devido ser um conceito que reconhece três matrizes de origem: a) o desenvolvimento local como expressão de uma 
lógica de regulação horizontal, refletida na dialética centro/periferia; b) o desenvolvimento local considerado como uma resposta a crises macroeconômicas e de ajuste produtivo (segundo Boisier quase todos os autores europeus tratam o desenvolvimento local a partir desta perspectiva); e, c) o desenvolvimento local estimulado em todo mundo pela globalização e pela dialética global/local a que esta implica.

O que caracteriza o desenvolvimento local, em princípio, é o protagonismo dos agentes/atores locais, na formulação de estratégias, na tomada de decisões econômicas e na sua implementação.

Embora o termo local possa remeter á localidade, ao lugar, essa ideia está incondicionalmente atrelada ao global no atual contexto da globalização, e alguns autores da teoria do desenvolvimento local (AROCENA, 2002; ALBUQUERQUE, 2001) e do desenvolvimento endógeno (BARQUERO, 2001), reconhecem que um conceito remete ao outro e vice versa. Para definir a noção de local não há outro caminho que referi-la a sua noção correlativa de global. "Quando algo se define como local é porque pertence a um global." (AROCENA, 2002, p.6). Assim, não se pode analisar um processo de desenvolvimento local sem referência à sociedade global na qual se está inserido, logo, necessário se faz reconhecer que a análise local não é toda a análise da realidade, ou seja, o local não é "mais real" do que o global.

O território de acordo com essa abordagem - diferentemente da concepção do desenvolvimento regional da década de 1960 - é concebido enquanto um agente de transformação social e não mero espaço funcional. Para essa abordagem o território socialmente organizado com suas características culturais e históricas próprias são aspectos muito importantes, uma vez que a sociedade não se ajusta passivamente aos processos de transformação existentes, mas sim desenvolve iniciativas próprias, locais, considerando as suas particularidades territoriais nos níveis: econômico, social, político e cultural.

$\mathrm{Na}$ concepção de Albuquerque (2001), o desenvolvimento econômico local pode ser entendido como:

Um processo no qual os atores ou as instituições locais mobilizam-se para apoiar as diferentes ações, buscando criar, reforçar e preservar as atividades e empregos, utilizando os meios e recursos do território (...) que conduz a uma melhoria do nível de vida da população local e no qual podem ser distinguidas várias dimensões: econômica (...); 
sociocultural (...); formação de recursos humanos (...); políticoadministrativa (...), e ambiental. (ALBUQUERQUE, 2001, p.77 e 136).

Outra característica do desenvolvimento local é a descentralização político- territorial, com enfoque estratégico no desenvolvimento de "baixo para cima", ou seja, em que as decisões partem da comunidade local, justamente por terem um caráter difuso e serem sustentadas por fatores não apenas econômicos, mas também sociais, culturais, e, territoriais; essas estratégias de desenvolvimento mostram maior interesse e preocupação com a satisfação das necessidades básicas do território, a melhoria do emprego, da renda e da qualidade de vida, assim como a conservação da base de recursos naturais e do meio ambiente. Neste sentido a participação e aliança entre poder público, iniciativa privada, instituições locais e sociedade civil, são fundamentais para a construção de uma política de desenvolvimento local; eficiência produtiva, competitividade, pesquisa e informação, gestão compartilhada e inovação são, dentre outros, elementos considerados importantes para a construção de uma política de desenvolvimento local.

\subsubsection{DESENVOLVIMENTO ENDÓGENO}

A formação do paradigma do desenvolvimento endógeno, segundo Barquero (2001), deu-se como resultado da convergência de duas linhas de pesquisa: uma teórica, que originou se da busca de uma noção de desenvolvimento que levasse em consideração os efeitos da ação pública no progresso de localidades e regiões atrasadas; e, outra empírica, que se originou da interpretação dos processos de desenvolvimento industrial em localidades e regiões do sul da Europa. Para esse autor o desenvolvimento endógeno pode ser visto como:

(...) um processo de crescimento econômico e de mudança estrutural, liderado pela comunidade local ao utilizar seu potencial de desenvolvimento, que leva a melhoria do nível da vida da população (...) propõe-se a atender às necessidades e demandas da população local através da participação ativa da comunidade envolvida. (BARQUERO, 2001, p.39). 
Trata-se de uma interpretação voltada para a ação, em que são identificadas três dimensões, segundo Barquero (2001), que ocorrem nesse processo: a econômica, caracterizada por um sistema específico de produção capaz de assegurar aos empresários locais o uso eficiente dos fatores produtivos e a melhoria dos níveis de produtividade, o que lhes garante a competitividade; sociocultural, em que os atores econômicos e sociais se integram às instituições locais, formando um denso sistema de relações que incorpora os valores da sociedade aos processos de desenvolvimento; e política, que se materializa em iniciativas locais, possibilitando a criação de um entorno capaz de incentivar a produção e que favorece o desenvolvimento sustentável.

Essa teoria também encara o território enquanto um agente transformador ativo, e não como suporte dos recursos e atividades econômicas, ele assume uma atitude ativa nos processos de desenvolvimento, devido à interação entre as empresas e os demais atores locais, que se organizam para desenvolver a economia e a sociedade.

De acordo com Barquero (2001), os sistemas produtivos locais e a política de desenvolvimento local, podem ser vistos como duas dimensões do atual processo de reestruturação ou ajuste produtivo, sendo a primeira dimensão (o sistema produtivo local), uma forma territorial, portanto, flexível de acumulação de capital; a segunda dimensão (política) pode ser interpretada como um dos instrumentos de regulação, cujo êxito se deve à maior capacidade para instrumentalizar a coordenação das ações e da cooperação entre os diferentes atores para o desenvolvimento local.

Competitividade (não espúria) e inovação também são características do desenvolvimento endógeno, bem como a gestão descentralizada do processo de desenvolvimento com proposição de ações vindas de "baixo para cima" no tocante ás políticas de desenvolvimento.

$\mathrm{Na}$ concepção de Haddad (2009), o processo de desenvolvimento é concebido e implementado a partir da capacidade que dispõe determinada comunidade para a mobilização social e política de recursos humanos, materiais e institucionais, em uma determinada localidade ou região.

Para Boisier (2001), o desenvolvimento endógeno, pode ser entendido como: 
um elevado estoque de capitais intangíveis e sinergético (...) em outras palavras, o desenvolvimento endógeno se produz como resultado de um forte processo de articulação de atores locais e de variadas formas de capital intangível, no marco preferente de um projeto político coletivo de desenvolvimento do território em questão. Todo processo de desenvolvimento endógeno se vincula ao desenvolvimento local de uma maneira assimétrica: o desenvolvimento local é sempre um desenvolvimento endógeno, mas este pode encontrar se e, escalas supra locais, como a escala regional por exemplo. (BOISIER, 2001, p.14).

Para esse autor, o processo de desenvolvimento endógeno, engloba não só as dimensões antes destacadas por Barquero (manifestando se nos planos: político; econômico; sociocultural), mas também no plano científico e tecnológico, como a capacidade interna de um sistema - em um território organizado -, para gerar seus próprios impulsos tecnológicos, capazes de provocar mudanças qualitativas nesse mesmo sistema.

$\mathrm{Na}$ concepção dessas duas abordagens (local e endógeno) as pequenas e micro empresas estão fadadas a ocupar um papel de protagonistas nos processos de desenvolvimento, devido à sua flexibilidade e capacidade empresarial e organizacional, sobretudo "por que são estas que geram emprego, renda e difusão territorial mais equilibrada" (ALBUQUERQUE, 2002, p.38). Na América Latina é expressiva a participação das pequenas e micro empresas no processo produtivo; no Brasil, de acordo com dados do $\mathrm{IBGE}^{7}$ referentes a 2012, as micro e pequenas Empresas, representaram 20\% do Produto Interno Bruto (PIB) brasileiro, sendo responsáveis por $60 \%$ dos 94 milhões de empregos no país e constituíram $99 \%$ dos 6 milhões de estabelecimentos formais existentes no país.

A base fundamental que se pode depreender destas duas abordagens é a do protagonismo dos atores locais na proposição, articulação, inovação e reestruturação do sistema produtivo e da sociedade, valendo se dos recursos disponíveis quer sejam eles de ordem natural, humana, tangíveis e intangíveis, como o saber-fazer, dentre outros.

\footnotetext{
${ }^{7}$ Instituto Brasileiro de Geografia e Estatística é uma fundação pública da administração federal brasileira, criada em 1934. O IBGE tem atribuições ligadas às geociências e estatísticas sociais, demográficas e econômicas, o que inclui realizar censos e organizar as informações obtidas nesses censos, para suprir órgãos das esferas governamentais federal, estadual e municipal, e para outras instituições e o público em geral
} 


\subsubsection{DESENVOLVIMENTO REGIONAL}

A abordagem regional tem suas origens de acordo com Cagmani (1997, apud Boisier, 2001, p.39) a partir dos anos 1950. Os conceitos chave das políticas regionais que vigoraram entre as décadas de 1950 até finais de 1970, foram: a infraestrutura como condição do crescimento econômico regional (concentrado); a atração de atividades externas; polos de desenvolvimento e economia de base exportadora. O contexto político econômico o qual se insere essa abordagem (subsequente ao pós II Guerra Mundial) foi marcado por um forte intervencionismo estatal, de caráter centralizador com ações realizadas de "cima para baixo". Acreditava se que a promoção do desenvolvimento nas regiões mais atrasadas pudesse ser efetivada mediante a adoção de medidas de desenvolvimento exógeno, estes que por sua vez, canalizariam uma parte do crescimento global da economia nacional para as regiões periféricas. 0 território neste sentido era visto de forma funcional, encarado apenas como suporte espacial dos investimentos. Essa política vigorou não só na Europa, mas a América Latina também a adotara, perdurando até meados dos anos 1990.

Essa abordagem do desenvolvimento, assim como as demais, não é bem definida por seus autores, uma vez que a fronteira conceitual entre o local e o regional não se faz muito clara. De acordo com Boisier (2001), a diferença entre ambos os conceitos reside em uma dupla questão escalar.

Por um lado, trata se de uma escala territorial, a qual, nos diferentes segmentos dela se encontram tanto o local como o regional. Por outro lado, se trata de uma escala funcional, pouco precisa também, mas dotada de certa sensatez; por exemplo, é evidente que a função de promover o emprego se entende hoje como uma função muito apropriada à escala local, mas é igualmente evidente que uma função como a promoção da investigação científica e tecnológica (parte importante da ideia de desenvolvimento), altamente dependente do funcionamento de um sistema de ciência e tecnologia, não poderia ser considerada função local, mas sim regional, que seria a escala funcionalmente adequada. (BOISIER, 2001, p.11, grifo nosso). 
No entanto, "desenvolvimento regional" para Boisier (2001) pode ser entendido como "um processo de mudança estrutural localizada (num espaço territorial denominado região), que se associa a um permanente processo de progresso da própria região, da comunidade que habita nela e de cada indivíduo, habitante de tal território". (BOISIER, 2001, p.7).

Nesta perspectiva, o desenvolvimento está associado a três dimensões, a relação espacial, referente à própria região; a social, com a comunidade que nela habita; e a individual, a de cada indivíduo membro da comunidade.

Para esse autor, a linha de separação entre o local e o regional será sempre casuística e arbitrária.

\subsubsection{DESENVOLVIMENTO SUSTENTÁVEL}

As diferentes abordagens que foram e estão sendo construídas pela observação, reflexão e experiências do cotidiano de diversas sociedades e localidades do planeta, tem possibilitado o rompimento, em certa medida, com o paradigma do "crescimento econômico". Uma das abordagens que tem propiciado esse rompimento, dentre outras, é a abordagem de desenvolvimento sustentável e includente.

O paradigma da sustentabilidade tem suas raízes em diversos estudos elaborados por teóricos de diferentes áreas do conhecimento desde meados de 1960, como pode se depreender na obra da bióloga Rachel Carson, intitulada de "Primavera Silenciosa", na qual a autora desperta a atenção da comunidade internacional, anunciando a morte de rios, o envenenamento dos solos pelo uso de agrotóxicos, a destruição das florestas, a poluição das grandes cidades e das águas.

A elaboração de um relatório intitulado "The Limits of the Growth", tornou se outra obra de projeção internacional, que tratava de problemas cruciais para o futuro desenvolvimento da humanidade, tais como energia, poluição, saneamento, ambiente, saúde, tecnologia e crescimento populacional, reforçando e evidenciando o impacto do crescimento acelerado da economia no mundo, sob pena da saturação dos recursos naturais, bem como o agravamento da poluição. 
Desde os anos 1970 a atenção dispensada a essas problemáticas ambientais, levou a uma ampla reconceitualização do desenvolvimento, levando a criação da teoria do ecodesenvolvimento ${ }^{8}$.

A partir de 1972, através da Conferência das Nações Unidas sobre o Ambiente Humano, realizada em Estocolmo, Suécia essa a ideia passa a ganhar força de forma institucionalizada. Organizada pela ONU, esta conferência reuniu 113 países e constituiu-se num importante acontecimento histórico na busca de soluções para os problemas ambientais que se apresentavam em todo o mundo, evidenciando as causas desses problemas e seus efeitos negativos não só para o meio natural, como para toda a humanidade, dessa forma a conferência apontava a necessidade de mudanças nos modelos de desenvolvimento econômico, nos hábitos e no comportamento dos indivíduos em relação ao meio ambiente.

O conceito de Desenvolvimento Sustentável formulado pela Comissão Brundtland só foi definido, no entanto, em 1987, com a publicação do documento intitulado "Nosso Futuro Comum", trazendo a definição oficial de desenvolvimento sustentável adotado por muitas instituições, inclusive pela OMT (1980, 1989, 1991, 2001, 2003, 2005):

Desenvolvimento Sustentável é aquele que atende às necessidades do presente sem comprometer a possibilidade de as gerações futuras atenderem a suas próprias necessidades. (COMISSÃO MUNDIAL SOBRE MEIO AMBIENTE E DESENVOLVIMENTO, 1991, p.46).

Durante a Conferência das Nações Unidas sobre Meio Ambiente e Desenvolvimento, conhecida como ECO-92, realizada no Rio de Janeiro em 1992, o conceito foi promovido, reafirmado e utilizado como ferramenta necessária no planejamento estratégico para a solução dos problemas ambientais contemporâneos.

\footnotetext{
${ }^{8}$ O termo ecodesenvolvimento foi cunhado na década de 1970, uma abordagem sobre desenvolvimento que é fundamentada na harmonização de objetivos ambientais e econômicos.
} 
Diversos documentos resultaram da conferência, no entanto, o principal foi a Agenda 219: um plano global de ação a ser implementado por todos os governos. Tem 40 capítulos, cerca de 115 programas e 2.500 ações, preparados para o século $X X I$, para promover o desenvolvimento sustentável em escala global, tentando conciliar o desenvolvimento com a preservação ambiental.

O paradigma da sustentabilidade propiciou uma nova perspectiva sobre a concepção de desenvolvimento. Avanços nas proposições de ações e pactos têm ocorrido desde então, através de diversas conferências sobre a temática (Johanesburgo'2002; RIO+20; etc.), entretanto, depreende se da realidade que esses pactos não têm demonstrado ser a garantia de mudança da realidade, pois continuam insuficientes para resolver a problemática resultante do crescimento econômico desequilibrado talvez devido à ineficiência quanto à colocação em prática (por parte dos governos, instituições privadas e sociedade civil) das ações estabelecidas e pactuadas.

Relevantes avanços epistemológicos na concepção de desenvolvimento ocorreram, de acordo com Sachs (2008), principalmente durante as três décadas que separaram a Conferência de Estocolmo (1972) e a Cúpula sobre Desenvolvimento Sustentável realizada em Johanesburgo em 2002.

As contribuições de Kalecki e Seers de que o desenvolvimento deveria ser analisado não somente em termos de crescimento de PIB, mas em primeiro lugar em termos de emprego; além das contribuições de Amartya Sen, (redefinindo desenvolvimento em termos da universalização e garantia do exercício efetivo de todos os direitos humanos: políticos, civis, cívicos; econômicos, culturais e sociais, ambientais), foram importantes para a evolução do conceito de desenvolvimento sustentável, pois este passou a integrar a dimensão social.

\footnotetext{
${ }^{9}$ A Agenda 21 é um documento que foi elaborado durante a conferência sobre o meio ambiente "Rio92", que apresenta como um dos principais fundamentos da sustentabilidade, o fortalecimento da democracia e da cidadania através da participação dos indivíduos no processo de desenvolvimento, combinando ideais de ética, justiça, participação, democracia e satisfação de necessidades, reforçando que, antes de se reduzir a questão ambiental a argumentos técnicos, deve-se consolidar alianças entre os diversos grupos sociais responsáveis pela consolidação das transformações necessárias. Esse documento é bastante extenso e abrange diversas questões relevantes e proposições para se atingir um desenvolvimento que seja sustentável, como o combate á pobreza, mudança nos padrões de consumo, dentre outros.
} 
O trabalho tem um status especial, devido ao duplo valor, intrínseco e instrumental já que o trabalho decente abre o caminho para o exercício de vários outros direitos, logo da cidadania.

Portanto, para Sachs (2008) o desenvolvimento includente deve ser fundamentado em um trabalho decente ${ }^{10}$ para todos.

O autor define sete critérios ou dimensões da sustentabilidade (SACHS, 2002, p.85): Social, Cultural, Ecológico e Ambiental, Territorial, Econômico e Político.

Propõe que o desenvolvimento sustentável deve ser um processo ambientalmente responsável, socialmente justo e economicamente viável. O modelo de desenvolvimento sustentável requer uma nova relação, uma dimensão que acrescenta a sustentabilidade ambiental e a sustentabilidade social, a partir de um imperativo ético para agir em solidariedade com as gerações atuais e futuras.

O turismo, fenômeno dotado de uma prática social, tem sua participação no desenvolvimento, e, portanto uma responsabilidade não só para com a biosfera, mas também com a construção de sociedades democráticas e mais justas. Nesse sentido, órgãos da ONU como a OMT, a UNEP, a World Travel \& Tourism Council (WTTC) e a Earth Council têm avançado nas discussões sobre a sustentabilidade em publicações relacionando a Agenda 21 ao turismo. Existem diversas entidades ao redor do mundo que trabalham o desenvolvimento do turismo dentro de uma perspectiva sustentável; no Brasil, as principais instituições que defendem a sustentabilidade no turismo são: a Eco Brasil, o Instituto de Hospitalidade, a Associação Brasileira de Ecoturismo e Turismo de Aventura.

\footnotetext{
10 Trabalho Decente é definido como o trabalho adequadamente remunerado, exercido em condições de liberdade, equidade e segurança, capaz de garantir uma vida digna. Para a Organização Internacional do Trabalho (OIT), a noção de trabalho decente se apoia em quatro pilares estratégicos:

a) respeito às normas internacionais do trabalho, em especial aos princípios e direitos fundamentais do trabalho (liberdade sindical e reconhecimento efetivo do direito de negociação coletiva; eliminação de todas as formas de trabalho forçado; abolição efetiva do trabalho infantil; eliminação de todas as formas de discriminação em matéria de emprego e ocupação); b) promoção do emprego de qualidade; c) extensão da proteção social; d) diálogo social.
} 


\subsubsection{DESENVOLVIMENTO TERRITORIAL}

De acordo com Boisier, talvez "desenvolvimento territorial" seja o mais amplo sentido de desenvolvimento. Considerado o conceito de território associado à ideia de recipiente e não à ideia de conteúdo.

Para o autor, o território pode mostrar pelo menos três características de complexidade crescente: "território natural" - concebido como o espaço intocado, sem intervenção humana; o "território equipado" - com algum tipo de intervenção humana, como a infraestrutura de transportes, construção, qualquer atividade extrativa; e, o "território organizado" - denotando a existência de atividades de maior complexidade, de sistemas de assentamentos humanos, redes de transporte, mas, sobretudo, da existência de uma comunidade que se reconhece e que tem como auto referência primária o próprio território, com alguma estrutura de administração, logo, esses territórios passam a serem sujeitos de intervenções que são promotoras do desenvolvimento. Considerando esta perspectiva Boisier (2001, p.7) afirma que: "O desenvolvimento territorial refere-se à escala geográfica de um processo e não a sua substância".

Notável se faz a dificuldade que a maioria dos teóricos tem em relação à delimitação e definição de cada uma dessas abordagens: desenvolvimento local; desenvolvimento endógeno; desenvolvimento regional, dentre outros, que ora se fundem e se confundem, como pôde ser apreendido nessas teorias; dificuldade a qual a esses teóricos reconhecem, dado o caráter complexo do desenvolvimento.

Para Boisier, o que pode ser concluído, é que ao menos durante uma fase inicial de um longo ciclo de expansão territorial dos processos de crescimento e desenvolvimento, o crescimento pode ser induzido desde "cima" e também desde "baixo", todavia, o desenvolvimento se mostrará sempre como um processo local, endógeno, descentralizado, capilar e contínuo ou descontínuo sobre o território. Portanto para ele, os adjetivos de desenvolvimento, "são redundantes e tautológicos, já que só dizem o que o próprio conceito de desenvolvimento diz. São em melhor dos casos, copulativos e não disjuntivos". (BOISIER, 2001, p.19)

Com o intuito de ampliar a reflexão, uma das contribuições que reconhece se aqui como crucial acerca de uma compreensão sobre desenvolvimento, é a de 
Amartya Sen, em que o mesmo encara o desenvolvimento "como um processo de expansão das liberdades reais que as pessoas desfrutam." (SEN, 2010, p.55). Em sua obra, intitulada "Desenvolvimento como Liberdade", Sen, demonstra que esse processo está essencialmente conectado às oportunidades que ele oferece à população de fazer escolhas e exercer sua cidadania, incluindo não somente a garantia dos direitos sociais básicos, como saúde e educação, mas também segurança, liberdade, habitação e cultura.

Vivemos um mundo de opulência sem precedentes (...), mas também de privação e opressão extraordinárias. Ver o desenvolvimento como expansão de liberdades substantivas dirige a atenção para os fins que o tornam importante, em vez de restringi-las a alguns dos meios que, inter alia, desempenham um papel relevante no processo. (SEN, 2010, p.9).

Compreende-se, que uma análise consistente do desenvolvimento se faz a partir de uma visão multi e interdisciplinar, com abordagens que relacionem saberes sociológicos, econômicos, políticos, geográficos, antropológicos, dentre outros, considerando os fatores, as dinâmicas e as inter-relações desse processo. Afirma-se, à luz de toda a reflexão e dos elementos que foram considerados até aqui, que o processo de desenvolvimento está repleto de fatores e de dimensões que são internos e externos ao território ou região em que ocorre. Logo, para uma compreensão que seja substanciosa e ampla, este fenômeno precisa ser apreendido enquanto algo complexo, uma vez que está vinculado aos movimentos da sociedade que o compõe, por sua vez também complexa.

\subsection{A FORMAÇÃO DO TERRITÓRIO E O DESENVOLVIMENTO DAS PRÁTICAS SOCIO ECONÔMICAS EM GOIÁS E PIRENÓPOLIS - BREVE HISTÓRICO}

Para compreender o processo de formação do território goiano e o desenvolvimento das práticas sócio econômicas em Goiás, e, sobretudo Pirenópolis, necessário faz-se retomar o período colonial no Brasil.

No século XV concomitantemente á sua "descoberta", o Brasil, constituiu se em colônia de exploração, cuja organização produtiva voltou se para satisfizer as demandas externas, essencialmente com a adoção do regime de trabalho escravo.

A economia brasileira caracterizou se por ciclos econômicos: sendo o 
primeiro do pau Brasil, com a retirada da árvore de valor econômico pujante devido á qualidade da madeira; seguindo se o ciclo do açúcar, com o cultivo da cana, planta de valor econômico agregado devido ao produto de seu refino, o açúcar, e, posteriormente ao ciclo do ouro, com a extração desse minério valioso no mundo todo. Entretanto esse projeto econômico ocorreu com o único objetivo: explorar os recursos do Brasil para satisfazer o mercado externo europeu, propiciando o processo de acumulação primitiva do capital de Portugal.

A base política fundamentou se na centralização administrativa, primeiro com as Capitanias Hereditárias e posteriormente com a implantação do Governo Geral, consolidando assim o Pacto Colonial.

No decorrer dos séculos XVI e XVII, as regiões interioranas do país permaneceram quase no esquecimento, devido ao fato de o sistema de colonização ter tido como base o latifúndio monocultor açucareiro e escravocrata, que era concentrado na faixa litorânea, uma vez que esta oferecia como vantagem a boa qualidade de solo e clima e principalmente a facilidade de escoamento da produção, fruto da exploração.

O ciclo da cana de açúcar foi bastante rentável, no entanto, por um período curto de tempo, durante a dominação holandesa (1637-1654) que ia do litoral maranhense ao norte da Bahia. Em 1654 ocorreu a insurreição pernambucana, na qual os senhores de engenhos brasileiros expulsaram os holandeses do Brasil. Esse evento inaugurou o declínio do ciclo da cana de açúcar no país. Os holandeses então concentraram todos seus investimentos em suas colônias no Caribe, como tecnologia, e capital. Portugal retomou o controle do nordeste brasileiro, mas não conseguiu competir com o açúcar batavo antilhano, dessa forma a corte lusa ordenou o início do desbravamento do Brasil, adentrando ao interior em busca de metais preciosos e mão de obra indígena escrava, pois o negro tornou se mercadoria cara devido á insurreição pernambucana (1654).

Ainda no século XVII, duas linhas de penetração para o interior do Brasil estabeleceram se: uma devido ao bandeirismo em busca de novas riquezas, oriunda do centro-sul, portanto paulista, e, outra à catequese Jesuíta, oriunda do norte por via fluvial do Tocantins.

As incursões pelos bandeirantes ao território goiano ocorrem com as expedições, principalmente as de Bartholomeu Bueno da Silva, o Anhanguera, 
alcunha que em tupi guarani - linguagem dos índios, primeiros habitantes desse território - significava "diabo velho", este que "por ser homem astuto e bem instruído, catequizava e reduzia os índios à sua sujeição" (FONSECA, apud BERTRAN, 1996, p.46), "astuto" por ter criado no imaginário dos índios, a figura mítica do "diabo", pois colocava fogo em garrafas de cachaça e ameaçava queimar as aldeias indígenas caso os índios não revelassem onde estava o ouro.

No entanto, a conquista do território goiano pelos portugueses, ocorreu com o filho de Anhanguera, que herdara o mesmo nome e figura mítica do pai; Bartholomeu Bueno da Silva em 1725 descobre a primeira lavra aurífera na cabeceira do Rio Vermelho, local em que se fundou o primeiro núcleo de povoamento: o Arraial de San'tana (atual Cidade de Goiás, que fora capital do Estado até 1937), entretanto, essa conquista se deu com percalços, pois embora os índios de certa forma temessem o Anhanguera, e terem sido dóceis ao primeiro contato, eles não se sujeitavam á lógica do explorador, não submetendo se ao trabalho escravo e resistiram á entrada dos exploradores, mesmo sendo massacrados; dessa forma, o "colonizador" precisou ir á África buscar a mão de obra escrava para continuar o projeto de conquista e exploração. A partir das primeiras bandeiras estabeleceu se a luta pela posse de terra entre os colonizadores e indígenas, que culminou no extermínio dos índios e na posse da terra pelos conquistadores, que a transformaram em fonte de poder econômico e político.

O povoamento de Goiás ocorria com o estabelecimento dos "Arraiais", e nessa fase, "caracterizou se pela irregularidade e pela falta total de planejamento" (SOUZA E CARNEIRO, 1996, p.15). Os primeiros arraiais que surgiram em Goiás foram reflexo da busca frenética dos bandeirantes pelo ouro, de modo que formaram se três regiões ou zonas de povoamento, composta pela concentração desses diversos arraiais. Meia Ponte (atual Pirenópolis) fazia parte da região centro-sul juntamente com os Arraiais de Santa Cruz, Santa Luzia (Luziânia), Jaraguá, Vila Boa (Goiás), Cocal e Barra, além dessas regiões (exceto alguns arraiais que surgiram dispersamente), o restante do território caracterizava se por um vazio demográfico. A maior concentração aurífera ocorreu em torno da Serra Dourada, no arraial de Sant'anna (Cidade de Goiás) e da Serra dos Pireneus, no arraial de Meia Ponte (Pirenópolis), já que esses arraiais ofereciam maior quantidade de ouro. A partir da descoberta aurífera, durante a 
primeira metade do século XVIII, a região passou a receber um grande fluxo migratório.

A sociedade em Goiás durante o período colonial estava dividida entre homens livres e escravos, a condição existencial dos escravos nas minas era de intensa exploração: tinham péssima alimentação e graves doenças que eram causadas pelo trabalho contínuo nas águas dos rios; além dos castigos impostos para a sujeição dos mesmos, fatores que determinavam o tempo de vida "útil", que não ultrapassava a 7 anos de trabalho.

A decadência da mineração em Goiás, que se deu em um processo paulatino, concluída por volta de 1800, ocorreu devido a diversos fatores, como: as técnicas rudimentares de extração de ouro (bateia), carência de mão de obra escrava, má administração local, mas, sobretudo ao esgotamento do ouro, que por sua vez direcionou os homens livres a dedicarem se á atividade agrícola, mesmo que esta de nada servisse para remediar a crise, já que a produção era apenas para a subsistência, no entanto, o poder político e econômico era centrado nas mãos de famílias que detinham grande posse de terras. Dentro desse processo econômico, vigente á época, tem destaque as grandes propriedades rurais que se estruturaram lentamente, via "sistema de patrimônio (posse de terra, sem qualquer vínculo jurídico), cujos limites eram definidos pela capacidade financeira daquele que se apossava da terra e a cultivava de modo extensivo" (SOUZA E CARNEIRO, 1996, p.39), essas fazendas produziam para subsistência e o excedente era vendido no mercado interno. Além dos grandes fazendeiros, havia os meeiros, parceiros e agregados, que prestavam serviços aos fazendeiros em troca de pífias porcentagens dos lucros obtidos com o gado e a lavoura.

Se por um lado o desenvolvimento da agropecuária em Goiás no século XIX possibilitou a organização e o crescimento das vilas, por outro, consolidou as bases do coronelismo - em que o fazendeiro era o representante do poder econômico e político local - que marcou, no período, o alicerce da política brasileira.

A partir de 1870, ligeiras mudanças de ordem política e social evidenciam se: como a participação nos movimentos nacionais liberais no Brasil em prol da campanha abolicionista e contra o regime escravista - embora em Goiás já houvesse uma diminuição do emprego de escravos na produção, uma vez que 
após o declínio da mineração os escravos tenham se tornado "mercadoria" cara, sendo então substituídos por meeiros, parceiros. Com a abolição da escravidão, inicia se o modo de produção capitalista, que transforma a propriedade privada e a força de trabalho em mercadoria.

Cabe ressaltar que Goiás participa também do movimento liberal republicano que ocorria em âmbito nacional, entretanto, a República não conseguiu concretizar os anseios de liberdade e justiça social em Goiás, pois "as famílias importantes locais formaram as oligarquias e os coronéis, com seus capangas armados, constituir-se-ão no poder econômico político local e regional" (SOUZA E CARNEIRO, 1996, p.51). O coronel era constituído o chefe político graças ao voto de cabresto, á coerção, á fraude eleitoral; elementos que não propiciavam a participação política de fato das demais classes sociais.

O isolamento a que foi relegado Goiás na segunda metade do século XIX, ocorre devido não só á sua localização, mas descentralização do poder, que levou ao predomínio da prepotência local dos coronéis do interior; a pobreza, a ignorância, levaram ao aprofundamento e enfraquecimento do poder central e fortalecimento do poder local, a expressão dessa situação em Goiás se consolidou posteriormente, já no início do século XX com as oligarquias, sobretudo da família Caiado, período conhecido como "Caiadismo" (1912-1930).

Já nesse momento, a pecuária tornara se a atividade comercial de maior importância na economia de Goiás, e, com a construção da estrada de ferro em 1913 na cidade de Ipameri, o Estado passa a participar do comércio interno de carnes e propicia um maior fluxo migratório. A força de trabalho nesse momento continua a ser sob a forma de agregados, camaradas, ou seja, não completamente monitorizada:

O camarada era um trabalhador que prestava serviços na pecuária, na lavoura e outros setores, além de ser obrigado a comprar os gêneros necessários para sua sustentação no armazém da fazenda, onde prestava serviços. Neste regime de trabalho o ajuste de contas era uma forma de manutenção compulsória do trabalhador na terra" (SOUZA E CARNEIRO, 1996, p. 24).

Em âmbito nacional, o processo de acumulação capitalista no centro-sul do país e a Revolução de 1930, deslocam o polo de desenvolvimento da agricultura para o setor urbano industrial e determina novas funções para as regiões semi- 
isoladas como Goiás, passando a incorporar definitivamente a região centro oeste ao processo produtivo nacional, entretanto, como fornecedora de matéria prima barata, além da função de ser esta região absorvedora de população migrante, como forma de subsidiar o processo de industrialização no Brasil.

A Revolução de 1930 leva ao poder em Goiás Pedro Ludovico Teixeira (este que fazia parte do núcleo de oposição á hegemonia caiadista), que fora responsável por inaugurar uma nova fase de "desenvolvimento" político econômico e social no estado, essa fase é conhecida como a "era Ludovico", por ser este o período em que a família Ludovico deteve o poder político, que perdurou entre os anos de 1930 a 1964.

Pedro Ludovico buscou criar condições para impulsionar a ocupação do estado com vistas á expansão do capitalismo, para implementação de tal empreita, necessário seria a garantia de uma infraestrutura básica que ligasse o centro oeste ao sul do país, e, seguindo a ideologia nacional desenvolvimentista á época, Ludovico cria o Banco do Estado de Goiás; as Centrais Elétricas de Goiás (CELG) e, sobretudo muda a capital de Goiás (então Goiás Velho, localizada na região Noroeste do estado), para a região central do estado, iniciando assim em 1933 a construção do município de Goiânia, capital do estado. A escolha da região para mudança da capital deveu se à topografia plana, ao bom clima, à abundância de água, além da proximidade à estrada de ferro, características bastante distintas da região de antiga capital goiana, que dificultava a estratégia "desenvolvimentista". A construção de Goiânia só foi possível devido ao apoio do governo federal, impulsionando o projeto político econômico nacional conhecido como "Marcha para o Oeste"11.

O fluxo migratório intenso para Goiás resulta em conflitos sociais constantes, e inúmeras lutas pela posse da terra, como as de outrora, no entanto, esta fruto das tensões provocadas pelo avanço do modo de produção capitalista.

Esse novo marco na história e no desenvolvimento do Estado de Goiás, não se resumia somente em aspectos positivos, o Estado possuía uma série de

\footnotetext{
${ }^{11}$ A "Marcha para o Oeste", foi uma política nacional, realizada por Getúlio Vargas, então presidente do Brasil, a partir de 1938, que tinha como objetivo quebrar os desequilíbrios regionais no país, com ocupação dos vazios demográficos e, com a estratégia, sobretudo de diminuir a pressão social no centro sul do país, encaminhando esses excedentes populacionais para áreas que produziam matérias primas e gêneros alimentícios a baixo custo, subsidiando assim a implantação da industrialização no centro-sul do país. Essa estratégia foi viabilizada em um primeiro momento pelos projetos de ocupação nos estados do Mato Grosso, Paraná e Goiás, e passa a ser também uma etapa preliminar de ocupação da Amazônia, região até então inexplorada.
} 
dificuldades, relatadas assim por PALACIN (1994, p.108):

O desenvolvimento do Estado estava longe de ser satisfatório. Para tomar um único índice: o censo de 1940 constatou que, entre 563.262 pessoas de mais de 10 anos, só 148.937 sabiam ler e escrever, $32 \%$ dos homens e $20 \%$ das mulheres, um homem entre três e uma mulheres entre cinco. As comunicações, a saúde, a instrução, a carência, a descapitalização da economia, a estrutura da propriedade, entre outros, eram problemas ainda intactos, trabalho para várias gerações.

Com a inauguração de Goiânia no final dos anos 1930, e a construção de Brasília na década de 1960, a região centro oeste deparou se novamente com o progresso e suas interferências, como a mudança de hábitos da população local que passou a se deparar com os apelos do "mundo moderno", e Pirenópolis não ficou isenta a esse processo.

Após o governo de Pedro Ludovico Teixeira, a "era Ludovico", tem continuidade com os governos de José Ludovico de Almeida e posteriormente com Mauro Borges Teixeira, até o advento do golpe em 1964, que instalou no país um processo ditatorial de intervenção militar.

O período entre os anos de 1954 a 1960 é marcado por uma intensificação na construção de estradas que interligam todo o estado de Goiás; construção do aeroporto internacional de Goiânia (no governo de José Ludovico de Almeida).

A gestão de Mauro Borges Teixeira (filho de Pedro Ludovico) que vai de 1960 a 1964, inspirou se no Plano de Metas do governo de Juscelino Kubistchek, e tinha como objetivos: acelerar o processo de acumulação e criação de novas empresas, com o intuito de elevar o nível de vida da população para reduzir os conflitos sociais da década de 1960. Seu governo buscou apoio e alianças principalmente com as classes subalternas do campo, fundamentando a proposta de reforma agrária, controlada a partir do sistema combinado agro urbano. A proposta de reforma agrária implantou se em certa medida através das experiências de produção cooperativa e coletiva, no entanto essa terra era comprada, o que reafirmou a propriedade privada da terra, o cooperativismo foi uma opção para propiciar econômica e tecnicamente uma produção moderna.

Essa reforma agrária foi uma tentativa de solucionar os antigos e graves problemas sociais, decorrentes do avanço da fronteira econômica uma vez que, apesar da "Marcha para o Oeste", a estrutura agrária continuava intocada 
devido á maioria das terras estar nas mãos de uma minoria.

O governo Mauro Borges foi um marco na história da gestão estadual em Goiás, uma vez que este "foi o primeiro a desenvolver um plano global, que contemplou todas as áreas de desenvolvimento econômico do estado" (SOUZA, 1996 , p. 88); a partir desse governo, nenhuma outra administração que o sucedeu pode desvencilhar se do planejamento. O planejamento abrangeu diversas áreas: agricultura, energia elétrica, pecuária, transporte e comunicações, cultura, educação, saúde, assistência social, levantamento de potencial dos recursos naturais e turismo. Para atender aos anseios do Plano, a reforma administrativa também fora realizada, criando estatais autônomas (as autarquias), e as paraestatais (companhias de economia mista). Esse Plano de governo foi possível de execução em razão de dois fatores: a expansão do capitalismo no país, exigindo assim maior integração de Goiás no processo econômico, o que fortalecia a intervenção estatal, e, o fato de a principal base de apoio desse governo ser a organização dos trabalhadores rurais, o que levou à possibilidade de questionamento da estrutura de poder dos grandes proprietários de terra. $\mathrm{O}$ governo de Mauro Borges fez a tentativa de cumprir com a obrigação de qualquer estado: colocar se a serviço do interesse comum, entretanto, essa premissa conflitava com os interesses das classes dominantes, e, com o agravamento da crise nacional e o golpe militar, impediram Mauro Borges de lograr muitas das metas estabelecidas em seu Plano de governo, sendo ele deposto em 1964, dessa forma a tentativa de reforma agrária e a democracia, foram bandeiras derrotadas.

Houveram mudanças em termos econômicos entre os anos de 1964 a 1984, período de intervenção militar. Os governos que sucederam o de Mauro Borges - Otávio Lage (1966-1970), Leonino Caiado (1971-1975), Irapuan Costa Junior (1975- 1978), Ary Valadão (1978 a 1982) - comprometeram se com o modelo econômico de internacionalização conservadora da agricultura, mas também com a Industrialização já ao final da década de 1970, com a criação do Banco de Desenvolvimento do Estado e o do Distrito Agroindustrial de Anápolis (DAIA), sobretudo com a implantação de diversas indústrias farmacêuticas.

O desenvolvimento da agricultura e da pecuária, embora excluindo a maioria da população rural, provocou grandes transformações na economia e foi fator decisivo para acelerar o êxodo rural no estado. 


\begin{abstract}
A política agrícola do período, que era voltada para a modernização da grande propriedade, denominada de "modernização conservadora", teve efeitos perversos como a aceleração do êxodo rural e a exclusão dos pequenos produtores, que foram marginalizados dos benefícios do crédito rural e dos demais instrumentos de política agrícola que beneficiaram o setor, contribuindo para o aumento da concentração de renda (FERNANDES, 1987, p.50).
\end{abstract}

Se os avanços no campo econômico se fizeram pujantes propiciando o aumento da acumulação capitalista, sobretudo devido à concentração da propriedade de terras nas mãos de poucos, somada à política agrária de incentivo a esses grandes proprietários de terras no período de intervenção militar, o mesmo não ocorreu no campo social, que passa a ganhar atenção somente nos governos de Iris Rezende e Santillo. Ao final do período da ditadura militar e abertura política, alguns movimentos populares organizados fizeram pressão á esses governos, reivindicando que fossem redimensionados os recursos do estado para as áreas de saneamento básico, educação, saúdem habitação popular melhoria da infraestrutura das cidades interioranas, com eletrificação, pavimentação asfáltica, entre outras.

Embora esses governos tenham enfrentado uma conjuntura econômica extremamente difícil que ocorria em nível nacional, ganhando eco nos estados da federação, notável foi a contribuição que tiveram para a redução das carências sociais, com investimentos significativos em políticas sociais: nas áreas de saúde, saneamento básico e eletrificação rural.

Apesar da década de 1980 ter sido marcada por uma conjuntura econômica recessiva, Goiás, conseguiu aumentar a produção agrícola, ampliar empregos no setor industrial e atingir taxas de crescimento econômico acima da média nacional. Contraditoriamente, não logrou atender às crescentes demandas sociais, mesmo com a redução de seu território em 1988, destinada á criação do estado do Tocantins.

$\mathrm{Na}$ última década do século $\mathrm{XX}$ e a primeira do século $\mathrm{XXI}$, os avanços na agricultura, pecuária e indústria se fizeram notáveis, consolidando assim o projeto de acumulação capitalista, posicionando o estado como pujante fornecedor de matérias primas, sobretudo da agroindústria.

Cabe ressaltar que o aumento da produção pecuária e agrícola tem cada vez mais consumido a natureza do bioma cerrado: de acordo com dados da 
organização ambientalista WWF (World Wild Foundation), cerca de $60 \%$ do cerrado goiano já foi degradado, dando lugar a pastagens, $6 \%$ foram destinados à agricultura, 14\% destinados à ocupação urbana e construção de estradas, e, somente $19 \%$ do cerrado ainda se encontram conservados. A água, outro elemento de grande relevância no território goiano (uma vez que o estado é um divisor continental de águas, possuindo abundância de água tanto de superfície quanto subterrânea) tem sido alvo de degradações, quer seja pelo uso insustentável, quer seja devido á poluição.

\subsection{PIRENÓPOLIS: PERCORRENDO A TRILHA DOTURISMO}

Para se compreender o objeto de estudo em questão - $O$ desenvolvimento do turismo em Pirenópolis -, faz se necessário em primeiro momento conhecer as características e o contexto ao qual reside o mesmo.

Dessa forma compreender o espaço, o território, os processos históricos de ocupação, e das práticas sócio econômicas, tornam se procedimentos fundamentais.

\subsubsection{CARACTERIZAÇÃO DO MUNICÍPIO}

O município de Pirenópolis está situado no Estado de Goiás, região Centro- oeste do Brasil e está a uma latitude 15051'09" sul e a uma longitude 48 $57^{\prime} 33^{\prime \prime}$ oeste e altitude de 770 metros. Seu território possui uma área atual de 2.227,793 km². Localizado na Microrregião do Entorno de Brasília e Mesorregião do Leste Goiano, Pirenópolis faz fronteira com os municípios de Abadiânia, Anápolis, Cocalzinho de Goiás, Corumbá de Goiás, Goianésia, Jaraguá, Petrolina de Goiás, São Francisco de Goiás e Vila Propício. Com posição geográfica privilegiada, está distante $120 \mathrm{~km}$ de Goiânia, capital do estado, e $150 \mathrm{~km}$ de Brasília, capital federal do país. O município é composto pela zona urbana e a zona rural, esta que conta com 10 núcleos de povoamento, denominados no linguajar local de "povoados". 
Pirenópolis é cortado de norte a sul por uma formação de cuesta $^{12}$; a região possui uma hidrografia formada por vários cursos d'água, sendo os principais (do ponto de vista urbano): o rio das Almas, o córrego Lava pés e o córrego da Prata, que cortam a cidade, e que até pouco tempo atuavam como limites naturais de seu perímetro urbano. Os demais rios que percorrem 0 município são: Corumbá, Dois Irmãos, Dos Patos, Padre Souza, Das Pedras e Do Peixe, além de dezenas de ribeirões e córregos responsáveis direta e indiretamente pelo abastecimento de água no município, bem como pela formação das dezenas de cachoeiras. De acordo com SIQUEIRA (2001), diversos ecossistemas estão presentes no município, "com predomínio do cerrado e suas diferenciadas fisionomias, além das matas de galeria, dos campos rupestres entre outros". (SIQUEIRA, 2001, p.19).

O Parque Estadual dos Pireneus é a mais importante Unidade de Conservação do município e da região: criado em 1987, com o objetivo de preservar a fauna, a flora e os mananciais ali existentes, protegendo sítios naturais de excepcional beleza e assegurando condições de bem-estar público, abrange áreas de três municípios goianos, Corumbá de Goiás, Cocalzinho de Goiás e Pirenópolis. Com uma área de 2.833,26 hectares, o Parque possui características únicas que o torna de valor singular, dentro da área, está localizado o segundo maciço mais alto do Estado de Goiás, o Pico dos Pireneus com 1.380 metros de altitude e é o divisor continental de águas.

O município conta ainda com boa parte de sua área natural preservada graças à existência de 7 Reservas Particulares do Patrimônio Natural (RPPNs) sendo que uma delas tem atividades parcialmente voltadas á prática do ecoturismo e turismo de aventura - além da APA dos Pireneus e do Monumento Natural Cidade de Pedra, totalizando o município 10 Unidades de Conservação.

A dinâmica populacional do município segue a realidade dos municípios do interior de Goiás, isto é, apresentam um decréscimo populacional. Segundo os dados da SEPLAN-GO, em 1980 Pirenópolis contava com uma população de aproximadamente 29.329 habitantes. Todavia, desde então vem ocorrendo um decréscimo populacional. O censo do ano 2000 já indicava que a população

\footnotetext{
${ }^{12}$ A Cuesta é uma formação de relevo escarpado em um dos lados com um suave declive em outro, constituindo "degrau", que se elevam sobre o solo até mil metros de altura, formando grandes paredões, cujo topo não é pontiagudo como as serras, mas sim uma vasta área plana.
} 
havia se reduzido para 21.245 habitantes, o que representa uma perda de aproximadamente $28 \%$ da população em 20 anos. Contudo, esta situação está mudando nesta última década já que segundo a contagem da SEPLAN em 2010 a população era de 23.006 habitantes demonstrando que há um arrefecimento no êxodo populacional.

Analisando os dados da SEPLAN/GO é possível verificar que a dinâmica populacional em termos de ocupação do território, apresentou transformações significativas: até o censo de 1980 a população rural composta por 22.677 habitantes, era três vezes maior que a população urbana (composta por 6.652 habitantes). A partir da década de 1990, essa dinâmica se modifica, a maioria da população passa a habitar a zona urbana, e, os censos seguintes demonstraram que a zona rural do município apresentou uma evasão da população rural compensada pelo crescimento da população urbana. Atualmente, de acordo com dados da SEPLAN/GO do último censo demográfico de 2010 do total da população (23.006 habitantes) do município, 15.563 habitantes residem em zona urbana e o restante (7.443) em zona rural, o que demonstra que Pirenópolis não está isenta ao processo de globalização do mundo, em que a maioria da população passa a viver em áreas urbanas, é o efeito da dinâmica do global rebatendo na dinâmica local.

Em termos de educação, de acordo com dados dos IBGE de 2012, o município dispõe de 22 escolas de ensino fundamental, sendo 13 destas mantidas com verbas municipais, 4 escolas de ensino médio, todas mantidas pelo estado, 11 escolas de ensino pré-escolar, sendo 1 delas particular e as demais municipais e 1 Universidade Estadual (UEG), que oferece os cursos de tecnologia em Gastronomia e tecnologia em Hotelaria (até 2013 era oferecido o curso de tecnologia em Turismo, no entanto, o curso fechou de acordo com assessor dos cursos de tecnologia da UEG, devido à falta de demanda).

A infraestrutura que presta serviços de saúde oferecida á população, de acordo com dados do IBGE de 2009 é composta por: 1 hospital particular, 1 hospital público estadual, 11 postos de saúde municipais.

O município conta ainda com 1 unidade de suporte básico do $\operatorname{SAMU}^{13}$. $\mathrm{O}$

\footnotetext{
${ }^{13}$ O Serviço de Atendimento Móvel de Urgência (Samu/192) é um programa do governo federal que tem como finalidade prestar o socorro à população em casos de emergência. O serviço é público, portanto gratuito, o atendimento de urgência e emergência é realizado em qualquer lugar.
} 
município dispõe de clínicas odontológicas, de exames laboratoriais, farmácias, dentre outros, todos particulares.

Em termos de infraestrutura de segurança, o município dispõe de 1 delegacia da polícia civil, que não funciona aos finais de semana, 1 delegacia da polícia militar, 1 destacamento do corpo de bombeiros, todos localizados na área urbana.

A rede de comunicação do município é composta por telefonia fixa e móvel, correios e telégrafos, Internet com acesso discado, banda-larga e via rádio e 1 rádio local comunitária. E a rede financeira é composta por diversos bancos, a cidade conta com 1 caixa eletrônico do banco "Caixa Econômica" que fica localizado no Centro de Atendimento ao Turista no centro histórico, no entanto o município ainda não tem um caixa eletrônico do tipo "24 horas", que concentra diversos bancos no mesmo caixa.

O município é abastecido com água de dois sistemas de captação, que é realizado por gravidade. Em relação ao sistema de esgoto, o município ainda não tem em funcionamento uma rede de esgoto (embora tenha uma estação de tratamento construída), sendo assim, as fossas sépticas são a alternativa que todas as residências e empreendimentos dispõem. O lixo gerado no município é depositado em um lixão ${ }^{14}$, inclusive os lixos hospitalares, que de acordo com a ONG WWF (2012) é "todo depositado dentro de uma vala e enterrado", atualmente existem aproximadamente 22 catadores tirando o sustento do lixão. Há um projeto de coleta seletiva e reciclagem desde 2011 denominado: "Água Brasil", uma parceria entre a ONG WWF Brasil, Fundação Banco do Brasil, Ministério do Meio Ambiente, Agência Nacional de águas e a prefeitura de Pirenópolis. O resultado desse projeto, dentre outros, foi a elaboração do Plano de Gestão Integrada de Resíduos Sólidos.

Atualmente a economia da cidade é composta em parte com atividade ligada mineração do quartzito micáceo, com a finalidade de uso em revestimentos e pisos. A agropecuária, assim como na maior parte do estado de Goiás, também é uma importante atividade econômica desenvolvida, de acordo com dados do Instituto Mauro Borges, é a segunda atividade em geração de PIB. E o

\footnotetext{
${ }^{14}$ Lixão - local em que o lixo é depositado sem qualquer tipo de tratamento. Isso significa que nada é planejado para receber os resíduos sem agredir o meio ambiente. O lixão é fonte de poluição: o chorume liberado pelo lixo e outras substâncias podem contaminar o solo e a água. Os resíduos a céu aberto favorecem a proliferação de ratos e insetos no local.
} 
turismo que em sua faceta econômica tem ganho relevância principalmente nos últimos 20 anos, sendo o setor de serviços o primeiro em geração de PIB no município.

\subsubsection{PIRENÓPOLIS E A LONGA CAMINHADA COM VISTAS AO DESENVOLVIMENTO}

O processo de desenvolvimento da cidade inicialmente se funde com a história do próprio processo de colonização do Centro-Oeste, que caracterizou se pela posse da terra pelo colonizador europeu, que a transformou em fonte de poder econômico e político pelo extermínio dos índios. (SOUZA E CARNEIRO, 1996).

O mesmo pode ser de forma sucinta dividido em quatro períodos/ciclos: o ciclo do ouro (1727-1800); da agricultura e comércio (1800 - 1880); do isolamento e das artes $(1890$ - 1930) e por último o atual: mineração de pedra quartzito micáceo e turismo.

Pirenópolis foi fundada em 1727, denominada primeiramente de "Minas de Nossa Senhora do Rosário de Meia Ponte", recebeu esse nome segundo ao costume que os sertanistas tinham em se dar a qualquer "descoberta" o nome de santo que o calendário registrasse no dia em que se realizava o descobrimento, - neste caso, sete de Outubro, dia de Nossa Senhora do Rosário -, vindo posteriormente a ser denominada de "Arraial de Meia Ponte".

A busca por riquezas na época do Brasil-Colônia, fez não só os bandeirantes portugueses como Bartolomeu Bueno da Silva e Manuel Rodrigues Tomar - fundador da então "Minas de Nossa Senhora do Rosário de Meia Ponte" -, adentrarem os sertões de Goiás, como posteriormente inúmeros outros portugueses e aventureiros mineiros ou não provenientes de diversas partes do Brasil, em busca do ouro de aluvião, retirado das margens do Rio das Almas, como nos atesta Jarbas Jayme (1971):

A fama das riquezas de Goiás crescia, dilatava se, arrancando de cada canto do Brasil, um coração a pulsar de alegria e cheio de ambição, que marchava rumo á terra promissora, onde esperava encontrar, com pouco sacrifício, o precioso metal (...) os aventureiros se espalharam (...) e foi assim que o garimpo do Rio das Almas se incrementou e cresceu em população. (JAYME, 1971, p.79). 
Foram esses aventureiros bandeirantes e garimpeiros e seus respectivos escravos negros, os primeiros a povoar esse território - após a expulsão dos índios que habitavam essa região. Alguns desses aventureiros eram "pessoas de maus costumes, e os crimes se praticavam impunemente", segundo Jarbas Jayme (1971):

Até os juízes ordinários não raras vezes, abusando das respectivas investiduras torciam a vara da justiça e se excediam (...). Alguns sacerdotes, pelas injunções mesológicas ou motivos outros, corriam parelha com os maus elementos.(JAYME, 1971, p.84).

Desde a fundação do "Arraial de Meia Ponte", até o auge da mineração, houve um grande fluxo migratório que ocorreu nesta região principalmente devido á facilidade encontrada na exploração deste tipo de jazida aurífera: ouro de aluvião (onde faz se o uso da bateia para a retirada do ouro que se encontra nas margens do rio). Além da extração do ouro, o comércio tropeiro era significativo, uma vez que a localização geográfica do arraial era privilegiada, tornando o um entreposto comercial (o ouro extraído nas minas de Cuiabá e Vila Boa, cujo destino final era o Rio de Janeiro, inevitavelmente passavam por Pirenópolis).

Ao mesmo tempo em que havia vantagem nesse tipo de extração aurífera - uma vez que o trabalho era menos árduo se comparado com a extração do ouro de mina -, as desvantagens também existiam, como a baixa produtividade e o esgotamento rápido das jazidas, de modo que o declínio da mineração fez se de maneira gradativa.

O auge da mineração em Goiás ocorre por volta de 1750, período em que a maioria das edificações religiosas (exceto a igreja Nossa Senhora do Rosário, maior edificação religiosa de Goiás à época) foram construídas. No entanto, quase trinta anos após o auge da mineração, o esgotamento aurífero já se fazia sentir, o que provocou um recrudescimento da economia do "Arraial de Meia Ponte".

Após o declínio total da mineração, por volta de 1800, os habitantes que resolveram permanecer em "Arraial de Meia Ponte", passaram a trabalhar com a agricultura de subsistência e pecuária extensiva. 
É também nesse momento histórico, por volta de 1819 que há a introdução da manifestação cultural da "Festa do Divino Espírito Santo", um patrimônio cultural com fortes influências da cultura portuguesa e que tem relevante importância para a comunidade. Esta manifestação foi reconhecida e registrada pelo IPHAN como patrimônio imaterial em 13/05/2010, devido a sua singularidade e diversos outros elementos que fazem parte da Festa - como as "Cavalhadas ${ }^{15 "}$ e os "Mascarados"16" - que a difere das demais "Festas de Divino Espírito Santo", que ocorrem em diferentes partes do Brasil.

Com o fim do ciclo do ouro, o "Arraial de Meia Ponte" só não esteve em um isolamento e ostracismo econômico total devido ao espírito empreendedor da figura que comandava o arraial e a região: Comendador Joaquim Alves de Oliveira, um brasileiro nascido em Pilar de Goiás, que construiu um dos maiores engenhos de cana de açúcar do Brasil à época: o Engenho da Fazenda São Joaquim (atual Fazenda Babilônia, que fora tombada como patrimônio cultural posteriormente em 1965 pelo IPHAN) tornando se um importante centro fomentador da economia regional, com a produção em larga escala de açúcar, bem como do algodão que era exportado para a Inglaterra no contexto da Revolução Industrial. Além da produção de açúcar e algodão, na fazenda eram plantados milho, feijão dentre outros gêneros agrícolas, havendo também uma pecuária intensiva, que supriam as necessidades da família, bem como dos escravos que trabalhavam e moravam na fazenda.

Segundo alguns viajantes ilustres (como Auguste Saint Hilaire, Luiz d'Alincourt entre outros) que passaram alguns dias nessa fazenda, a mesma era palco de muita prosperidade, e "boa convivência" tanto para o Comendador, sua família e "escravos" como para Meia Ponte; o proprietário era

\footnotetext{
${ }^{15}$ As Cavalhadas é o ponto auge da Festa do Divino Espírito Santo, uma tradição trazida pelos portugueses e que ocorre desde 1960, embora a Festa do Divino data de 1819. As cavalhadas basicamente é a encenação de batalhas medievais entre cavaleiros mouros e cavaleiros cristãos que ocorre no campo das cavalhadas (ou cavalhódromo).

${ }^{16}$ Os Mascarados fazem parte da festa, são cidadãos comuns que usam roupas extravagantes e máscaras confeccionadas artesanalmente com figuras de caras de animais, mais comumente boi e onça, montados a cavalo ou mesmo a pé, os mascarados saem fazendo algazarras pelas ruas da cidade e dançando nas casas em que, para isso são convidados, são brincalhões e alguns dizem que surgiram devido a ser esta a forma que cidadãos encontraram para mostrar indignação perante as autoridades, era uma espécie de protesto político ao que lhes desgostavam em relação ás condições de vida na cidade.
} 


\author{
dotado de "grande amor à justiça e bondade extrema", segundo consta nos \\ escritos de 1819 de Saint Hilaire (1978, p.6):
}

\begin{abstract}
Numa parte de suas terras o comandante de Meia-Ponte tinha deixado de lado o método primitivo adotado geralmente pelos brasileiros em suas lavouras. Passara a usar o arado e adubava a terra com o bagaço da cana (...). O açúcar e a cachaça eram vendidos em Meia-Ponte e Vila Boa, mas o algodão era exportado (...). Joaquim Alves foi o primeiro a demonstrar a vantagem dessas exportações, e seu exemplo foi seguido por vários outros colonos (...) ele tinha intenção de instalar no próprio arraial de Meia-Ponte uma descaroçadora, bem como uma fiação onde pretendia empregar as mulheres e as crianças sem trabalho (...). O lucro obtido com as exportações era tão garantido que Joaquim Alves não vacilara em se oferecer para comprar, à razão de 3.000 réis, o algodão produzido por todos os agricultores das redondezas.
\end{abstract}

Segundo Luiz d'Alincourt (1818):

O gênero mais considerável que se exporta é o algodão; e deve se confessar que (...). Joaquim Alves de Oliveira é o autor do aumento deste lucroso ramo de comércio, pelos desvelos e cuidados que tem posto na cultura da planta, animando, ajudando os cultivadores e reputando bem todo algodão daqueles que não tem meios de exportar por sua conta, o que até pratica com seus próprios escravos (...) se tem dado a esse gênio á agricultura, que não só tem feito à fortuna de sua casa, (...) mas até de Meia Ponte que bastantemente decaía (confissão geral do próprio povo) (...) enfim, Joaquim Alves é um gênio criador e benfazejo, e muitas casas do Arraial the devem a existência. (D'ALINCOURT, 2006, p.64).

Sobre o cotidiano e condições de vida dos escravos, segundo Saint Hilaire (1819):

As regras estabelecidas por Joaquim Alves quanto ao tratamento dado aos escravos consistiam em mantê-los bem alimentados e vestidos decentemente, em cuidar deles adequadamente quando adoeciam (...). Todo ano ele provia o casamento de alguns, e as mães só iam trabalhar nas plantações quando os filhos já podiam dispensar os seus cuidados. As crianças eram então confiadas a uma só mulher, que zelava por todas (...). O domingo pertencia aos escravos. Eles não tinham permissão para ir procurar ouro, mas recebiam um pedaço de terra que podiam cultivar em seu próprio proveito. Joaquim Alves instalara em sua própria casa uma venda onde os negros podiam comprar as coisas que geralmente são do agrado dos africanos. Nas suas transações o algodão fazia o papel do dinheiro. Dessa maneira ele livrava os escravos da tentação do roubo, estimulava-os ao trabalho acenando-Ihes com os lucros de suas lavouras. (SAINT HILAIRE, 1978, p.8).

As contribuições do Comendador á "Meia Ponte", extrapolaram a esfera econômica, sendo ele um fomentador de diversas ações políticas e de benfeitorias culturais e materiais.

Fora ele um dos responsáveis pela elevação da categoria de arraial á vila, tornando se esta em "Vila de Meia Ponte" no ano de 1832, conservando 
até este momento o mesmo nome, mas possuindo desde então uma Câmara Municipal e justiças ordinárias. Instalou e financiou a primeira tipografia de Goiás em sua própria Fazenda, que editou o primeiro jornal do Centro Oeste, a "Matutina Meiapontense"; criou a primeira biblioteca da cidade para usufruto de seus concidadãos; a primeira banda de música, em 1830.

Entretanto, a fazenda teve seu declínio com a morte do seu proprietário em 1851, e, logo após a sua morte, em 1853 a vila é elevada á categoria de cidade.

A partir da segunda metade do século XIX, "Meia Ponte" passa por um processo de estagnação econômica, alavancada por um conjunto de fatores: abolição dos escravos, proclamação da república, mas especialmente pela mudança das rotas comerciais, uma vez que os principais comerciantes resolveram mudar se para o povoado de "Santana das Antas", (atual cidade de Anápolis) - devido ao relevo plano, que facilitava o transporte e o acesso), dessa forma o eixo comercial é deslocado para "Santana das Antas" e a cidade de "Meia Ponte" fica isolada.

No entanto, esse isolamento que do ponto de vista econômico é negativo, torna se um período de efervescência cultural, em que a cidade se (re) inventa, mudando seu nome para Pirenópolis "a cidade dos Pireneus" (em alusão á Serra dos Pireneus, cuja nomenclatura lembrava por alguns os Montes Pireneus da Europa, divisa da França com a Espanha), buscando ser um centro urbano cultural, com festas e apresentação de espetáculos, mantendo suas tradições, atividades culturais e festas populares. Nesse período são construídos alguns dos edifícios funcionais à época - que posteriormente, no século $X X$ foram tombados pelo IPHAN como patrimônio material, como 0 "Theatro de Pirenópolis", a "Casa de Câmara e Cadeia”, dentre outros.

Com a inauguração de Goiânia ao final dos anos 1930, e a construção de Brasília na década de 1960, Pirenópolis não ficou isenta ao processo de modernização e progresso, que se dava em âmbito nacional e estadual, de modo que a interferência e mudança dos hábitos e costumes da população local se fez presente.

Após estar por um longo período isolada economicamente, Pirenópolis tem sua economia reaquecida, mesmo que de forma tímida, a partir da década de 1930, primeiramente com a construção de Goiânia, sendo fornecedora de 
quartzito micáceo.

O quartzito micáceo, minério abundante na região, descoberto e usado ainda no período colonial, em que as pedras eram "utilizadas como chapas portáteis de fogão, bem como para revestir muros, calçar passeios e aposentos" (POHL, 1976, p.117), passa posteriormente a ser incorporado não só na construção civil e no calçamento da cidade de Pirenópolis - já no século $X X$ mas a ser extraído, beneficiado e comercializado de forma mais intensa, a partir da década de 1960, por ocasião da construção de Brasília. Esse minério criou de acordo com Almeida (2006):

(...) um mercado de trabalho intenso, não só na extração como também na comercialização do produto. Este meio de sobrevivência, influenciou na economia e favoreceu o crescimento do bairro do Alto Bonfim (na zona leste da cidade), que situado nas proximidades da pedreira, desenvolveu se com características típicas de um bairro popular, de formação espontânea. (ALMEIDA, 2006, p. 50, grifo nosso).

Com a abertura de estradas como a Belém-Brasília e a Brasília-Cuiabá, que facilitaram a movimentação não só pelo interior do estado e da região, mas também ligando o às regiões norte e sul do país, o município até então com sua economia baseada na agricultura, e, tímida extração mineral, passa a dar início de forma veemente à atividade mineradora, no entanto, não aurífera, como a de outrora.

Juntamente com a atividade de extração e comércio de quartzito micáceo, o turismo passa a figurar como uma nova, porém acanhada, possibilidade de sobrevivência para sua população, a partir dos anos 1970.

Em um primeiro momento, o turismo começa a acontecer de forma espontânea. A visitação ao município era realizada por compradores de pedra de quartzito micáceo provenientes de Brasília, Goiânia e de outras localidades próximas, além de políticos e pessoas encantadas pelo bucólico núcleo urbano composto por um patrimônio histórico e arquitetônico remanescente da exploração aurífera de outrora, e, dos recantos ambientais localizados em sua proximidade; esses visitantes tinham como o objetivo fruição de lazer aos finais de semana e feriados.

Entretanto, nesse momento o município não apresentava uma infraestrutura voltada para a atividade turística, com pousadas e restaurantes; havia como 
locais de hospedagem a Pensão central e o Rex Hotel, no entanto era comum acampamentos à beira do rio das Almas, local que não contava com infraestrutura para tal prática de lazer. Embora os acampantes trouxessem a maioria das coisas de que prescindiam (utensílios para cozinhar, comida, bebidas), eram visíveis os efeitos causados pelo uso indevido da área, uma vez que esta não dispunha de banheiros públicos em quantidade para atender a tal demanda, de forma que a maioria dos visitantes faziam suas necessidades fisiológicas nas matas ciliares e no próprio rio.

A partir da (re) descoberta de Pirenópolis (principalmente pelos brasilienses), os aspectos negativos carregados pela esteira do "progresso" começam a aparecer, como a especulação imobiliária, dentre outros como nos atesta Curado (1978):

Brasília, ao surgir, é para Pirenópolis faca de dois gumes. Se, por um lado, ao descobri lá com sua história, antiguidades, tradições folclore e recantos naturais a faz ressurgir no cenário goiano e principalmente dentro do setor turístico, por outro, tirou-lhe grande parte de seu patrimônio móvel de antiguidades, comprando os a preço de banana (...), das mãos de alguns elementos da própria terra, que se serviam de intermediários. (CURADO, 1978, p.91).

Ao final da década de 1970, um novo grupo social, além da comunidade local (formada basicamente por pirenopolinos ${ }^{17}$ ), passou a habitar o município. Provenientes de diversas partes do Brasil e do mundo, os hippies do movimento contracultura ${ }^{18}$, mudaram se para Pirenópolis, uma parte deles com a intenção de criar e viver em "comunidades alternativas", outros devido ao misticismo do Planalto Central. A primeira comunidade alternativa criada em Pirenópolis foi a "Terra Nostra", sita á área rural do município, no povoado de Bom Jesus. Algumas pessoas dessa comunidade eram artesãs que trabalhavam com o ofício de joias de prata e por terem um discurso e prática socialista, criaram a "Associação Cooperativista Rural Terra Nostra" - atualmente extinta -, implantaram o primeiro Ateliê Escola do Centro Oeste e passaram a ensinar aos

\footnotetext{
${ }^{17}$ Gentílico das pessoas nascidas no território de Pirenópolis; que se refere a Pirenópolis,

${ }^{18}$ Movimento contracultura dos anos 70 no mundo e no Brasil, foi um movimento de pessoas que adotavam um modo de vida comunitário, tendendo a um estilo de vida nômade e à vida em comunhão com a natureza, negavam o nacionalismo e as guerras, abraçavam aspectos de religiões como o budismo e o hinduísmo e estavam em desacordo com as economias capitalistas extremistas e totalitárias.
} 
jovens da cidade o ofício de joias em prata; posteriormente, o "ateliê escola" foi transferido para o centro histórico de Pirenópolis.

Os produtos desses artesãos eram em primeiro momento comercializado tanto em outros lugares do Brasil, como no exterior.

No início as ferramentas usadas para ensinar esses jovens eram particulares dos integrantes da comunidade, posteriormente a própria associação conseguiu adquirir as suas, e, os jovens aprendizes ao se formarem na arte desse ofício, começaram com o auxílio de integrantes da comunidade a montar suas próprias oficinas. Atualmente o município conta com cerca de 100 ateliês e mais de 300 artesãos dedicados ao ofício da prata. Outras comunidades alternativas, com diferentes propostas foram implantadas, no entanto, é evidente o papel importante que a "Terra Nostra" teve para Pirenópolis, tanto para formação de jovens que não tinham nenhuma outra perspectiva de trabalho na cidade á época (exceto o trabalho pesado da extração da pedra de quartzito), quanto para o início do turismo, pois com o apoio da prefeitura local, esses artesãos passaram a comercializar o produto de seus trabalhos também na cidade, o que ajudava além do patrimônio histórico e arquitetônico a atrair turistas.

Atualmente muitos dos proprietários de atividades ligadas ao turismo, como restaurantes, lojas de artesanato, ateliês, dentre outros, são remanescentes desses hippies ou seus descendentes que foram nascidos e/ou criados em Pirenópolis, principalmente dos empreendimentos que se encontram no centro histórico da cidade.

Embora já houvessem ocorrido algumas iniciativas por parte do governo estadual para compreender e ordenar a atividade turística em Pirenópolis, é somente a partir do final da década de 1980 que ocorre a implementação de algumas ações com vistas a um ordenamento da atividade turística como: a realização de treinamentos e qualificação de mão de obra com a participação do SENAC; ações no sentido de conhecer melhor os atrativos e as potencialidades; ações de marketing, uma vez que o objetivo da gestão pública estadual do período era dar visibilidade ao estado de Goiás.

Mas é especialmente a partir da década de 1990 que o turismo em Pirenópolis começa a esboçar os contornos do que viria a ser a atual fase que se encontra. $\mathrm{O}$ crescimento da visitação ao município nesta década, foi favorecido 
devido ao tombamento do patrimônio arquitetônico do centro histórico, realizado pelo IPHAN em 1989, há que se ressaltar que já haviam algumas edificações tombadas no início do século XX.

A implantação de políticas públicas como o $\mathrm{PNMT}^{19}$, e o $\mathrm{PED}^{20}$, orientadas a partir do nível federal (EMBRATUR), e consequentemente estadual (GOIASTUR), em Pirenópolis transformaram se em "tentativas" de organizar e impulsionar a atividade turística, já que não alcançaram o objetivo desejado, conforme será abordado posteriormente de forma mais detalhada no capítulo 1.4.

Como saldo positivo para o município, ficou a implantação de um Centro de Atendimento ao Turista; o diagnóstico do turismo da cidade; consultorias às empresas; planejamento estratégico da "cadeia produtiva" do turismo, dentre outras, que se deram graças á parceria junto ao SEBRAE, além da realização em parceria com o Grupo Nativa, na realização de inventários/ diagnósticos em propriedades rurais com vistas á expansão do turismo rural.

Cabe ressaltar como fato significativo a realização do primeiro curso de qualificação na área de condução de visitantes, este financiado pelo Fundo de Amparo ao Trabalhador (FAT) que faziam parte do Plano Nacional de Qualificação do Trabalhador (PLANFOR ${ }^{21}$ ), tendo tido este curso como desdobramento a organização dos condutores de visitantes e a criação em 1991 da Associação dos Condutores de Visitantes de Pirenópolis (ACVP). Os cursos de qualificação previstos no PED, também foram de importância para a qualificação das pessoas da comunidade local que tinham interesse em trabalhar com as atividades de turismo.

No que tange á política pública municipal, cabe evidenciar a criação da secretaria de cultura e turismo, e a criação do Conselho Municipal de Turismo (COMTUR. lei $n^{\circ}$ 305/97).

Em termos de infraestrutura de turismo essa década é marcada por um

\footnotetext{
${ }^{19}$ Plano Nacional de Municipalização do Turismo. (mais detalhes, ver nota no capítulo 1.4 referente a políticas públicas).

${ }^{20}$ Plano de Execução Descentralizada. (mais detalhes, ver nota no capítulo 1.4 referente a políticas públicas).

${ }^{21}$ O PLANFOR teve como objetivo principal o desenvolvimento de ações de educação profissional, buscando contribuir para a redução do desemprego e subemprego da População Economicamente Ativa (PEA); combater a pobreza e a desigualdade social; assim como elevar a produtividade, a qualidade e a competitividade do setor produtivo.
} 
aumento do número de empreendimentos voltados ás atividades características do turismo.

As primeiras pousadas formalizadas e com estruturas voltadas ao atendimento de turistas são inauguradas nesse período, a maior delas à época e até os dias atuais (Pousada dos Pireneus) construída fora do centro histórico em uma área verde, no bairro do Carmo; as demais em sua maioria passam a funcionar nos centenários casarões (reformados) sitos em sua maioria, no perímetro do centro histórico de Pirenópolis, o mesmo ocorrendo com os restaurantes, lanchonetes, lojas de artesanato e ateliês.

Nesse momento, os empreendimentos são implantados em parte por pirenopolinos, e, em parte por brasilienses, goianienses e os próprios hippies de outrora, que ao adquirirem tais imóveis, ao longo das décadas de 1980 a 1990, optam por viver e trabalhar na cidade. Ao final do século, é iniciado o processo de revitalização do centro histórico com a restauração de igrejas, reconstrução do Cine Pireneus e a reforma do Theatro Pirenópolis, o que tornou a cidade ainda mais atrativa.

$\mathrm{Na}$ entrada do século XXI, o turismo passa a ser consolidado como atividade econômica e social de Pirenópolis. Em termos de infraestrutura turística pública, a cidade recebe a construção de um portal turístico, com implantação de mais um Centro de Atendimento ao Turista (com maior parte da verba proveniente do governo federal); o Cavalhódromo ${ }^{22}$ (com investimentos do governo estadual); o

portal de entrada e sinalização do Parque dos Pireneus (com verba proveniente do governo estadual) a reforma da ponte do rio das almas, um dos "cartões postais" da cidade e que serve de ligação entre o centro histórico e o bairro do Carmo, a readequação da fiação elétrica do perímetro do centro histórico, que passa a ser subterrânea; o projeto Beira Rio: um projeto de revitalização da orla do rio das Almas (uma parceria entre a prefeitura, IPHAN com financiamento do MTUR); restauração do Museu de Arte Sacra (localizado na Igreja do Carmo) e criação do Museu do Divino (sito prédio da Antiga Casa de Câmara e Cadeia), ambos realizados com uma parceria entre a prefeitura, IPHAN, IBRAM com

\footnotetext{
${ }^{22}$ Local construído para a realização das Cavalhadas, uma manifestação que é o auge da Festa do Divino Espírito Santo; o espaço é composto por uma grande arena gramada e arquibancadas de concreto e camarotes. Eventualmente é usado como campo de futebol para a realização de campeonatos do município e já recebeu algumas edições do Festival de música Canto da Primavera.
} 
financiamento do Ministério do Turismo e do Ministério da Cultura.

A construção e implantação do campus da Universidade Estadual de Goiás (UEG) com os cursos de tecnologia em Turismo e tecnologia em Gastronomia; reforma e manutenção dos acessos rodoviários, também recebem atenção por parte do governo estadual nesse período.

É visível por todo o município a criação e melhoria da estrutura turística privada de atividades características do turismo: pousadas, atrativos naturais, restaurantes, lojas de artesanato, joalherias, cafés, bistrôs estão espalhados por todos os bairros da cidade, inclusive nos bairros que tem concentração de pessoas mais carentes, como o Bonfim, que, por exemplo, tem de acordo com o Cadastur $^{23}$ :

10 pousadas e mais 6 hospedagens do tipo cama e café, sem contar os empreendimentos informais. Além de investimentos privados em parte da zona rural e atrativos naturais. Os dados do período fornecidos pela prefeitura atestam o aumento desses empreendimentos.

Em termos de atrativos culturais, diversos festivais foram criados e realizados neste período com vistas a atrair turistas, alguns criados e custeados pelo governo estadual como o Canto da Primavera e Festival Gastronômico, outros por iniciativas de ONGs e empresas culturais, como o Slow Filme e Festival de Inverno, Piri Jazz, Festa Literária de Pirenópolis - FLIPIRI dentre outros, além de festividades criadas atendendo ao calendário nacional, como o Carnaval Cultural e Natal, estes últimos totalmente custeados e realizados pela prefeitura. A cada ano mais e mais festivais e atrações culturais são realizadas em Pirenópolis, algumas tem continuidade periódica, outras acabam por sucumbir.

No entanto, as festividades seculares, que são originárias e realizadas pela atitude cooperativa da população local, como: a Festa do Divino Espírito Santo (embora seja atualmente custeada em grande parte pelo governo estadual); as comemorações da Semana Santa; Festa do Morro; Festa da Lagolândia, dentre outras, que ocorrem por todo o território pirenopolino, em sua maioria ligadas ás raízes católicas (mas com a parte profana), ainda permanecem fortes

\footnotetext{
${ }^{23}$ CADASTUR é o Sistema de Cadastro de pessoas físicas e jurídicas que atuam no setor do turismo. Executado pelo Ministério do Turismo, em parceria com os Órgãos Oficiais de Turismo nos 26 Estados do Brasil e no Distrito Federal, permite o acesso a diferentes dados sobre os Prestadores de Serviços Turísticos cadastrados.
} 
na cultura local e a maioria dos pirenopolinos participa da realização e as frequentam. Essas festividades atraem também visitantes dos municípios vizinhos, que partilham de traços culturais parecidos aos de Pirenópolis, uma vez que a maioria desses municípios teve a mesma formação sociocultural e econômica, tendo seus territórios em sua maioria, inclusive sido parte de Pirenópolis em tempos remotos.

Houve no período um avanço expressivo na implantação de políticas públicas, porém, cabe ressaltar que a maioria delas foram instituídas atendendo a uma demanda e orientação vindas do governo estadual, que por sua vez atende às demandas da Política Nacional de Turismo, conforme será abordado no capítulo 1.4. Entretanto, cabe destacar algumas intervenções, realizadas pela gestão municipal em diversas outras parcerias, como a criação do Fundo Municipal de Turismo - FUMTUR (lei n 435/02); a elaboração do estudo de imagem em mercado realizado pela consultoria Ornellas em 2008 (custeado pelo SEBRAE/GO); a participação de feiras de turismo, como Salão do Turismo, ABAV e feiras correlatas, de artesanato, dentre outras, apoiadas e custeadas em parte pelo COMTUR, Prefeitura e a Goiás Turismo (autarquia responsável pela gestão estadual do turismo) com a intenção de divulgar o "destino turístico"; o monitoramento de informações estatísticas sobre a "demanda turística" (com elaboração do instrumento de pesquisa e tratamento dos dados realizados pelo IPTUR); a atualização do inventário da "oferta turística"; elaboração do Plano Municipal de Turismo em 2012 (realizado e custeado sob a tutela do SEBRAE/GO); oferta de diversos cursos de qualificação na área do turismo (parceria entre a prefeitura, SENAC, governo federal via PRONATEC e GOIÁS TURISMO), dentre outras.

A elaboração e aprovação do Plano Diretor em 2002, fora uma ação relevante para o desenvolvimento do turismo, pois embora este seja um instrumento da política de desenvolvimento do território, está intrinsecamente ligado ao desenvolvimento do turismo enquanto atividade, sendo o grande norteador do uso e ocupação do território um instrumento essencial para a gestão pública ordenar não só o uso do território mas também de seus "recursos", tanto por parte de seus habitantes como por parte dos empreendedores, esses responsáveis pela produção capitalista do espaço.

Atualmente o município faz parte do Programa "65 destinos indutores" do 
Ministério do Turismo, e tem recebido premiações por melhorar a pontuação em alguns indicadores estabelecidos na metodologia do programa, dessa forma se tornando um "destino mais competitivo".

\subsection{O DESENVOLVIMENTO VISTO A PARTIR DA POLÍTICA PÚBLICA DO TURISMO NO BRASIL E NO ESTADO DE GOIÁS}

A história do planejamento e das políticas públicas no Brasil é recente quando comparada aos demais países que passaram a fomentar o turismo com o advento do capitalismo.

Segundo Beni (2006) o planejamento do turismo no Brasil é marcado por descontinuidades de gestão, diretrizes e macro indicações pouco claras, não objetivas e dificilmente reproduzíveis, o que dificulta a participação dos poderes públicos, das comunidades envolvidas e da iniciativa privada, em todos os níveis, municipal, estadual e federal.

As primeiras iniciativas de se planejar o turismo se deram a partir dos anos de 1930. Intervenções governamentais, pontuais foram realizadas principalmente nos anos de 1937 a 1945, como a proteção de bens históricos e artísticos nacionais e a fiscalização de agências e venda de passagens. Desde esta data até o final do período de ditadura militar, verifica-se uma preocupação do turismo enquanto um instrumento para reforçar a imagem do Brasil que as elites queriam mostrar, tanto para os brasileiros quanto para os estrangeiros.

Iniciativas de um planejamento do turismo mais consistente, em nível nacional ocorreram a partir de 1960, no contexto do "Estado Desenvolvimentista", na gestão de Juscelino Kubistchek, com a criação da COMBRATUR (Comissão Brasileira de Turismo). Esta comissão tinha por finalidade a coordenação, planejamento e supervisão da execução da política nacional de turismo, com o objetivo de facilitar o crescente aproveitamento das possibilidades do País, no que concernia ao turismo interno e internacional (Decreto n48.126, 19/04/1960).

Entretanto é a partir da criação da primeira instituição pública oficial de Turismo, a Empresa Brasileira de Turismo (EMBRATUR), juntamente com a criação do Conselho Nacional de Turismo (CNTUR), em 1966, pelo Decreto lei $n^{\circ}$ 55, 18/11/66, que ocorre de fato a definição da Política Nacional de Turismo. Neste momento, a Embratur era vinculada ao Ministério da Indústria e Comércio, e 
atuava sob a forma de empresa, não tinha receita própria e sua ação era basicamente o gerenciamento de recursos e benefícios provenientes de incentivos fiscais e financeiros destinados ao setor turístico.

A Política Nacional de Turismo estabelecia, segundo Beni (2006), de maneira genérica, os objetivos e atribuições dos operadores do setor no país, colocando o como integrante do sistema produtivo brasileiro.

Pode se depreender que no início, o Turismo no Brasil (seguindo a visão de muitos outros países), era encarado enquanto unicamente uma atividade econômica, inclusive estando ligado ao Ministério da Indústria e Comércio. A gestão era centralizada no poder público, perdurando dessa forma até a década de 1990.

A partir da década de 1970, diversos fundos de financiamento foram criados como o FUNGETUR ${ }^{24}$, dentre outros com vistas a desenvolver o setor, sendo que os empreendimentos que pleiteavam tais fundos deveriam pertencer a programas vinculados aos seus municípios ou estados, sob o gerenciamento da Embratur. (BENI, 2006).

De acordo com Beni (2006), essa política de direcionamento desses recursos financeiros que eram feitos pela Embratur, foi equivocada, mesmo tendo sido alertado por pesquisadores da área de turismo antes de sua realização. Primeiro por que esses investimentos eram vultosos, tendo sido "utilizados quase que integralmente em hotéis de luxo, de 250 mil dólares a unidade habitacional, em empreendimentos de valor não inferior a 25 milhões de dólares." (BENI, 2006, p.24), de acordo com o autor, não havendo estudo de viabilidade econômica, localização, formação de recursos humanos ou inclusão social. E segundo, por que esses investimentos eram voltados a atender um turismo internacional, o que na visão do autor deveriam ter como finalidade a consolidação do turismo interno para que posteriormente, fosse pleiteado o turismo internacional. Essa década é marcada pelo decreto lei 71.791 de 1973, que dispõe sobre as zonas prioritárias para o desenvolvimento do turismo, sendo estas delimitadas sob a égide do Conselho Nacional de Turismo (CNTUR), e o decreto lei 6.513 de 1977, que cria áreas e locais de interesse turístico, ficando a cargo da Embratur a implantação e manutenção atualizada o inventário dessas

\footnotetext{
${ }^{24}$ Fundo Geral de Turismo
} 
áreas e locais, bem como dos bens culturais e naturais protegidos por legislação específica, além da interlocução com os demais órgãos federativos envolvidos ${ }^{25}$.

A década de 1980 é marcada por diversas mudanças, sobretudo devido á implantação da nova Constituição, inclusive sendo o turismo citado na mesma, em seu artigo 180, no qual se atribui responsabilidades iguais a todos os níveis governamentais. O principal destaque no planejamento desse período foi à incorporação das questões ambientais na formulação de políticas públicas, lançando assim as "bases efetivas para o cenário de sustentabilidade ambiental e social." (BENI, 2006, p.25). É também nessa década que é estabelecido o Sistema Nacional de Turismo, colegiado responsável pela organização política do turismo no País, e que deveria centralizar o planejamento, coordenar e executar planos, programas e projetos, otimizando recursos, esse Sistema era composto pela Embratur, Ministério da Indústria e Comércio e pelo CNTUR.

Mudanças significativas nas políticas públicas de turismo têm início a partir da década de 1990, sob a gestão em nível federal primeiramente de Fernando Collor de Melo e posteriormente de Fernando Henrique Cardoso, que ampliam o debate entre o governo, a iniciativa privada, a academia e a sociedade. A atividade turística desse período, "passa a ser vista como engendradora de processos de desenvolvimento regional e, consequentemente, minimizadora de históricas desigualdades" (CRUZ, 2001, p.30). Esse enfoque deu-se, principalmente, em função do crescente significado econômico do setor de serviços no período, já que o turismo vinha adquirindo crescente importância econômica em nível mundial, revelada através a ascensão de sua participação no PIB mundial.

O período é marcado por um processo descentralizador na formulação das políticas públicas. Seguindo as recomendações da Organização Mundial do Turismo (OMT), para seus países membros, a Embratur criou o Plano Nacional de Municipalização do Turismo (PNMT), que era uma tentativa de incrementar o produto turístico brasileiro a partir da conscientização dos habitantes e dos governantes dos municípios sobre as benéfices econômicas da atividade

\footnotetext{
${ }^{25}$ IPHAN (Instituto do Patrimônio Histórico e Artístico Nacional); IBDF (Instituto Brasileiro do Desenvolvimento Florestal); SEMA (Secretaria Especial do Meio Ambiente); CNPU (Comissão Nacional de Regiões Metropolitanas e Política Urbana); SUDEPE (Superintendência do Desenvolvimento da Pesca).
} 
turística e tinha também como objetivo a descentralização das atividades de planejamento.

Entretanto, já em sua implementação, Beni (2006), detecta uma falha que viria a comprometer os resultados do Plano. A primeira providência a ser tomada de acordo com o modelo, deveria ser o Relatório do Inventário Turístico Nacional, que estabelecia o conhecimento prévio, por cada país, de seu espaço turístico nacional, essa etapa não fora realizada, devido a isso de acordo com Beni, "muitos municípios apresentaram-se como vocacionados para o turismo". (BENI, 2006, p.26).

Outra crítica que o autor faz ao Plano, é a desconsideração em relação ás inúmeras especificidades geográficas e culturais do País, oferecendo o mesmo modelo de implantação a todos os municípios, de acordo com Beni (2006), se houvesse sido realizada uma inventariação nacional, como proposto no modelo da Organização Mundial do Turismo, propiciaria a identificação de regiões turísticas a partir do agrupamento de atrativos, infraestrutura, equipamentos e parâmetros mercadológicos, caracterizando a divisão em zonas turísticas, ou seja, um diagnóstico bem elaborado teria sido efetivo na proposição do planejamento turístico.

Outras políticas estabelecidas nessa década são também os programas de polos turísticos, criação e Implantação do PRODETUR-NE ${ }^{26}$, turismo interno, formação de recursos humanos, produtividade e qualidade no setor turístico, fomento ao marketing internacional. No início dessa década, o Ministério da Indústria

e Comércio, passa a ter o Turismo figurando em sua nomenclatura e ao final da década, o Turismo é remanejado para outra pasta, passando a configurar o Ministério do Esporte e Turismo.

Esse período é marcado acima de tudo por um maior enfoque às políticas nacionais de preservação ambiental; seguindo as políticas iniciadas no período anterior, a Embratur institui programas focados no desenvolvimento sustentável das regiões do País, com recursos externos, majoritariamente provenientes do Banco Interamericano de Desenvolvimento (BID) e do Banco Mundial. Em parceria com o Instituto Brasileiro do Meio Ambiente (IBAMA), lançou o programa

\footnotetext{
${ }^{26}$ Programa de Ação para o Desenvolvimento do Turismo no Nordeste.
} 
denominado "Parques Naturais", que tinha como objetivo a geração de crescimento econômico e social nas regiões do entorno dos espaços naturais protegidos.

A entrada do século XXI é marcada por mudanças mais profundas, o Turismo ganha uma pasta exclusiva, sob a gestão federal de Luiz Inácio Lula da Silva e posteriormente Dilma Rousseff. Em 2003 é criado o Ministério do Turismo, com estrutura própria, orçamento específico e com possibilidade de centrar as ações especificamente no setor. A Embratur, dentro dessa nova estrutura, passa a assumir majoritariamente a promoção do País no exterior, no entanto, mantém a sua característica de pesquisa fornecendo dados para "orientar os processos de tomada de decisão, avaliar o impacto da atividade turística na economia nacional, e fomentar novos produtos e roteiros turísticos." (BENI, 2006, p.29).

A estrutura do Ministério do Turismo no que tange à criação, implementação e gestão das políticas públicas, nesse momento é composta pela Secretaria Nacional de Políticas de Turismo, responsável pela elaboração e desenvolvimento do instrumento de execução da Política Nacional de Turismo; a Secretaria Nacional de Programas de Desenvolvimento do Turismo, com o papel de subsidiar a formulação dos planos, programas e ações pertinentes à execução da Política Nacional do Turismo, bem como gerenciar o Fundo Geral de Turismo(FUNGETUR).

O Plano Nacional de Turismo (2003-2007) tem uma abordagem regional e descentralizadora, que perdura até os dias atuais (2013), desde então houve avanços e retrocessos na formulação, bem como na implementação e avaliação dessas políticas.

Essa abordagem regional ocorre em princípio por meio do Programa de Regionalização do Turismo, em que os estados brasileiros, recebem orientações do Ministério pelas Diretrizes Políticas e Diretrizes Operacionais do Programa, que devem ser repassadas aos municípios e às regiões participantes.

Como princípios das diretrizes operacionais do programa tem-se a participação, a sustentabilidade, a integração e a descentralização, apoiado pela criação de uma estrutura de coordenação que inclui a criação de instâncias de governança regionais, ou simplesmente entes responsáveis pela gestão do turismo na esfera regional capazes de promover a gestão coordenada do programa e a formação de parcerias para sua implementação. (BENI, 2006, p.30). 
$\mathrm{Na}$ opinião do autor, embora o Ministério apresente uma estrutura institucional apta a planejar o espaço turístico nacional, para ele, apenas as regiões que tiverem clareza do processo poderão obter êxito, pois:

\footnotetext{
Os Estados e os municípios ainda enfrentam enormes dificuldades e obstáculos para entender, aplicar, operacionalizar, e dar continuidade, em seus limites político-territoriais, às diretivas prescritas e aplicáveis em suas respectivas conjunturas. (BENI, 2006, p.31).
}

As principais dificuldades elencadas pelo autor nesse sentido seriam a falta de recursos humanos qualificados para a correta compreensão e aplicação das diretrizes e as deficiências institucionais no setor em várias regiões do país, que acarretam a não compreensão da política de regionalização, para Beni (2006) a consequência disso já é percebida com a criação de roteiros regionais e não de uma regionalização sustentável do turismo. Outra crítica que o autor faz em relação ao Mintur, se refere à promoção da roteirização regional, que de acordo com ele, esta serve de forma momentânea para questões mercadológicas, entretanto não é o instrumento correto com vistas a um desenvolvimento sustentável do turismo.

Para Beni (2006), um planejamento correto do turismo, viria a ser o que levaria ao desenvolvimento sustentável, calcado em planos diretores que definam cenários de articulação inter e intra cadeia produtiva, buscando a integração e identificação dos sujeitos do processo, sejam eles públicos e privados, focando a gestão compartilhada e também o compartilhamento de custos; que levem em conta os impactos do turismo, distribuindo com equidade os benefícios e o ônus, gerando empregos locais diretos e indiretos, visando à inclusão social, redistribuição da renda e redução da pobreza; que estimulem negócios lucrativos; que pensem estratégias para a transferência de renda de regiões mais ricas para regiões mais pobres e que abranjam a coesão política e social, a cooperação e o associativismo.

O segundo Plano Nacional (2007-2010) - Uma Viagem de Inclusão tem como mote principal a inclusão social, por meio do desenvolvimento e da geração de emprego e renda, e, pelo fortalecimento do mercado interno de turismo, tendo como estratégia a promoção do Brasil para os brasileiros. Diversos programas foram implantados com o objetivo de promover o acesso ao turismo por diferentes 
segmentos da sociedade, como o Viaja Mais Melhor ldade $^{27}$, entre outros.

Os objetivos gerais do plano consistiam em: 1) Desenvolver o produto turístico brasileiro com qualidade, contemplando as diversidades regionais, culturais e naturais; 2) Promover o turismo com um fator de inclusão social, por meio da geração de trabalho e renda e pela inclusão da atividade na pauta de consumo de todos os brasileiros; 3) Fomentar a competitividade do produto turístico brasileiro nos mercados nacional e internacional e atrair divisas para o País.

O processo de descentralização da gestão do Turismo permaneceu ainda como uma estratégia forte desse plano, com fortalecimento das instâncias de governança regional, realizada com a assessoria técnica do Instituto de Assessoria para o Desenvolvimento Humano (IADH), que inclusive posteriormente, elaborou uma pesquisa, a pedido do Ministério do Turismo, com o intuito de avaliar o Programa de Regionalização. A pesquisa culminou em um relatório com a avaliação, denominado "Avaliação do Programa de Regionalização - Roteiros do Brasil" compreendeu o período entre os anos de 2004 a 2010, e depreendeu-se da realidade que:

A avaliação sinaliza a urgência de uma maior sinergia entre as áreas do MTur, e deste com os Estados, municípios, instâncias de governança $\underline{\text { e }}$ atores locais, além da necessidade de maior descentralização de recursos. Nesse sentido, o Programa deve ter o seu foco na dimensão territorial do turismo, evitando-se sobreposição de atribuições entre áreas do MTur. Vale ressaltar que a gestão compartilhada e descentralizada está em construção no País. Avanços importantes foram feitos, mas há espaço para avançar ainda mais. Seis anos de implementação do Programa de Regionalização do Turismo - Roteiros do Brasil são pouco tempo para promover uma mudança de cultura política e administrativa que influencie todo o território nacional e que seja capaz de transformar paradigmas que alicercaram o desenvolvimento do turismo durante muito tempo. Entre eles, o de que o desenvolvimento da atividade turística é uma responsabilidade única do setor público. Ainda há muito para avançar na consolidação da cooperação entre instituições públicas e privadas, como aponta a avaliação. Também é importante destacar que num País de dimensões continentais, como o Brasil, será sempre um desafio buscar o desenvolvimento equitativo de todas as regiões turísticas. (AVALIAÇÃO PROGRAMA DE REGIONALIZAÇÃO, 2010, p.59. grifo nosso).

\footnotetext{
${ }^{27}$ O Viaja Mais Melhor Idade é um programa do Mintur, que visa promover a inclusão social de pessoas a partir de 60 anos, de aposentados e pensionistas, proporcionando-lhes oportunidade de viajar e usufruir os benefícios da atividade turística, para tal, empresas interessadas são cadastradas no programa, e oferecem pacotes de viagens e hospedagem com valores acessíveis a esse segmento da sociedade.
} 
Cabe salientar que nesse período houve a implantação de um Programa de destaque e que se dá em relação a alguns municípios turísticos, é o denominado "Estudo de Competitividade dos 65 Destinos Indutores do Desenvolvimento Turístico Regional", esse programa consistiu em princípio na identificação de destinos turísticos com capacidade de induzir o desenvolvimento regional.

Dentre 87 roteiros já identificados e elencados em 2006, durante o III Salão de Turismo - Roteiros do Brasil ${ }^{28}$, foram escolhidos 65 municípios turísticos - a partir de critérios estabelecidos - que fazem parte de 59 regiões turísticas em todos os Estados. Esses destinos foram priorizados para receber investimentos técnicos e financeiros do Ministério do Turismo, e tem a responsabilidade de propagar o desenvolvimento nos roteiros dos quais fazem parte e consequentemente, nas regiões turísticas que perpassam.

Em princípio, o objetivo era trabalhar esses destinos até 2010 com vistas a obter-se um padrão de qualidade internacional dos mesmos e consequentemente aumentando o nível de competitividade. Para tal intento, houve uma parceria com a Fundação Getúlio Vargas no sentido de se elaborar uma metodologia para diagnosticar e monitorar o nível de competitividade desses destinos, considerando 11 dimensões que englobam aspectos sociais, econômicos, de infraestrutura, capacidade empresarial, dentre outros.

Essa política foi efetivada em 2008, com a divulgação de relatórios anuais, os denominados "Índices de Competitividade dos 65 Destinos Indutores", e, desde então encontra se em vigor, entretanto, foram diagnosticados no relatório de Avaliação do Programa de Regionalização, alguns desafios, tais como: a desarticulação desses destinos com as regiões turísticas e instâncias de governança regionais, bem como a não compreensão por parte desses destinos quanto ao seu papel de indutor do desenvolvimento turístico regional, dentre outros, o que revela que o objetivo principal desse Programa - a indução do

\footnotetext{
${ }^{28}$ O Salão do Turismo é uma estratégia de mobilização, promoção e comercialização dos roteiros turísticos desenvolvidos a partir das diretrizes do Programa de Regionalização do Turismo - Roteiros do Brasil. Promovido pelo Governo Federal por meio do Ministério do Turismo, o evento apresenta o turismo brasileiro para o público em geral, que podem conhecer os roteiros turísticos das 27 unidades da Federação e adquirir pacotes e produtos/serviços turísticos. Conhecer e comprar o artesanato, os produtos da agricultura familiar e a gastronomia típica, além de assistir a manifestações artísticas de diversas regiões do País. A primeira versão do evento ocorreu em 2005 e o último foi realizado em 2011.
} 
desenvolvimento dos demais municípios da região -, não estava sendo atingido até aquela avaliação.

O Plano Nacional do Turismo atual (2013 - 2016) continua a ter como estratégia de implementação a gestão descentralizada, e tem como conjunto de diretrizes: 1) Geração de oportunidades de emprego e empreendedorismo; 2) Participação e diálogo com a sociedade; 3) Incentivo à inovação e ao conhecimento 4) Regionalização como abordagem territorial e institucional para o planejamento, e, como visão de futuro, o Plano tem uma meta ambiciosa, posicionar o Brasil como uma das três maiores economias turísticas do mundo até o ano de 2022. Considerando essa perspectiva, quatro grandes objetivos são delineados: 1) preparar o turismo brasileiro para os megaeventos (Copa do Mundo de Futebol 2014 e Olimpíadas 2016); 2) incrementar a geração de divisas e a chegada de turistas estrangeiros; 3) incentivar o brasileiro a viajar pelo Brasil; 4) melhorar a qualidade e aumentar a competitividade do turismo brasileiro; para alcançar tais objetivos, diversas ações são propostas no Plano.

Considerando o desenvolvimento das políticas públicas do turismo no Estado de Goiás, para se compreender o estágio atual a que se encontra, faz-se necessário retomar a década de 1970, pois, segundo Almeida (2002), é a partir desse período que a Embratur e o Plano Nacional de Turismo tiveram repercussões animadoras. No entanto é apenas entre os anos de 1970-1976, sob a gestão do governo de Leonino Di Ramos Caiado (no período da ditadura militar), que foram adotadas medidas para tomar o turismo como instrumento de desenvolvimento social e econômico.

Nesse período foi criado o Departamento de Turismo (DETUR), e um grupo de trabalho $\left(\mathrm{GTT}^{29}\right)$, foram identificadas as principais regiões com potencialidade turística para uma posterior implantação de um Sistema Estadual de Turismo. As regiões eleitas por este grupo foram: o Vale do Araguaia, Caldas Novas e as cidades históricas de Goiás e Pirenópolis, que já possuíam um princípio de práticas turísticas. De acordo com o Relatório da Secretaria Estadual de Indústria e Comércio de Goiás (1971), citado por Almeida (2002), o Estado não possuía experiência técnica nem estrutura político e jurídicofuncional no turismo, passando a espelhar- se nos demais Estados da federação

\footnotetext{
${ }^{29}$ O GTT foi criado pelo Decreto 188 de 19/07/71.
} 
no intuito de adquirir subsídios para a implantação de sua política de desenvolvimento do turismo.

De acordo com Almeida (2002):

A preocupação maior do GTT era fornecer os elementos para a criação do referido Sistema Estadual de Turismo, e suas análises e recomendações possibilitaram organizar uma estrutura de apoio ao desenvolvimento do turismo estadual e criar secretarias de departamentos direta e indiretamente ligados ao setor. (ALMEIDA, 2002, p.201).

Em 1972, o DETUR transforma-se em Empresa Goiana de Turismo Goiastur, que fora criada pela Lei n 7540 de 12/09/72, essa empresa existiu até 1999. A Goiastur - seguindo á lógica federal inicial das décadas de 1950-1960 - era uma diretoria subordinada à Secretaria Estadual de Indústria e Comércio, com uma superintendência de promoção de eventos e outra de operações com suas atribuições inerentes, ademais contava com um órgão consultivo, o Conselho Estadual de Turismo, e administrativo o Centro de Convenções, recebendo recursos que eram provenientes da locação de seu espaço físico ${ }^{30}$.

Em 1975, sob essa mesma gestão, através da Lei no 7.988/75, é definida a política estadual de Turismo, que conforme o artigo $1^{\circ}$ caracteriza-a como:

Art. 1․ - A Política Estadual de Turismo compreende o conjunto de diretrizes e normas ligadas ao planejamento e execução das iniciativas, públicas ou particulares, concernentes ao turismo e do interesse do desenvolvimento econômico, social ou cultural do Estado de Goiás.

Os planos de governo das gestões posteriores priorizaram os setores da agropecuária, da indústria, da infraestrutura e organização administrativa do Estado de Goiás. Na gestão de Irapuan Costa Junior (1975-1979), foi elaborado o plano de "Diretrizes Gerais e Setoriais da Ação de Governo", seguindo às ações do II Plano Nacional de Desenvolvimento, tendo como ênfase o desenvolvimento urbano e regional e o desenvolvimento de pesquisas, através da criação do Sistema Estadual de Planejamento, a Secretaria Estadual do Meio Ambiente (SEMA), o Instituto de Pesquisa Econômica e Social (IPES), Fundação Cultural

\footnotetext{
${ }^{30}$ Durante os anos em que a gestão pública do turismo esteve vinculada à Secretaria Estadual da Indústria e Comércio (1972 a 1999), os recursos para a Diretoria de Turismo eram oriundos de dotação orçamentária dessa Secretaria, o que deixava o turismo do ponto de vista político, a mercê dos interesses da Indústria e do Comércio de Goiás.
} 
de Goiás, dentre outros organismos de administração direta e indireta foram criados durante esta gestão.

Nos anos 1980, o Sistema Estadual de Planejamento foi desativado, na gestão de Ary Valadão (1979-1982), essa gestão é marcada por uma ênfase em projetos de caráter cooperativista no setor agropecuário, que contava com assistência técnica e apoio governamental, mas sem a interferência direta do estado. Na área do turismo, foram oferecidos diversos estímulos à iniciativa privada, e o governo assumia junto aos empresários o compromisso de intensificar a divulgação das cidades de Corumbá de Goiás, Formosa, Caldas Novas, Vale do Araguaia e Cidade de Goiás, tanto no Brasil como no exterior, com o objetivo principal de atrair divisas ao estado.

O período seguinte é marcado por um processo de redemocratização, sob a gestão de Íris Rezende (1983-1987), que estabelece um plano de governo que enfatizava como sendo "fundamental importância a participação do povo na elaboração das prioridades do governo". (SILVA, 2003, p.50). É nesse período que a Goiastur assina um protocolo de intenções junto à Embratur, para tentar aumentar o fluxo turístico no estado, esse protocolo denotou uma aproximação do estado junto ao governo federal. De acordo com Almeida (2002), a prioridade desse governo estava na implementação de uma infraestrutura turística, com postos de atendimento, projetos de terminais turísticos e de parques hoteleiros, publicação de jornais, com vistas a dar visibilidade ao estado, e, "treinamentos e qualificação de mão-de-obra com a participação do SENAC”. (ALMEIDA, 2002, p.201).

A gestão seguinte, de Henrique Santillo (1987-1990), no que tange ao turismo, o foco de trabalho da Goiastur esteve direcionado ao fomento e á fiscalização de iniciativas, planos, programas e projetos de turismo. Esse período caracterizou-se pela promoção de eventos, feiras e participação em feiras do segmento turístico, que divulgavam o estado, sobretudo com o lançamento da campanha "Goiás é bom demais", em 1988. Cabe destaque outras atividades que eram desenvolvidas pela Empresa: Levantamento das cavernas de São Domingos, no extremo norte do estado ${ }^{31}$; levantamento para diagnóstico no Programa Integrado de Três Ranchos, no extremo sudeste do estado e o

\footnotetext{
${ }^{31}$ É sob essa gestão que o estado de Goiás foi dividido, sendo assim criado o estado do Tocantins.
} 
lançamento da proposta para implantação do polo de desenvolvimento Turístico da Região Leste Goiana, a qual inclui como destaque as cidades de Cristalina, Corumbá de Goiás, Formosa, Luziânia e Pirenópolis.

No segundo mandato do governo de Íris Rezende e Agenor Resende (1991- 1994), foi construído o Centro de Cultura e Convenções de Goiânia, como estratégia para abafar a grande repercussão do acidente radiológico com Césio $137^{32}$, em uma tentativa de reverter a imagem negativa do estado.

Ainda nessa gestão, no ano de 1993, o turismo foi fortalecido na política estadual, com a vinculação de propagandas oficiais de turismo "como indústria do sorriso e da boa hospitalidade" (ALMEIDA, 2002, p.202), sendo estabelecidas parcerias entre a Goiastur e diversas instituições representativas do turismo: Associação Brasileira de Agentes de Viagens (ABAV), Sindicato dos Empregados de Turismo (SINDETUR), Sindicato dos Gerentes Empresariais de Turismo (SINGTUR), e Sindicato de Hotéis, Bares, Restaurantes e Similares (SINDHORBS). Na gestão seguinte, de Maguito Vilela e Naphitali Alves (19951998), houve uma maior atenção e apoio às áreas de esporte e lazer, e a inovação da malha rodoviária.

No percurso da década de 1990, o estado ganhou destaque em relação ao turismo ecológico, com a criação do Projeto de Execução Descentralizada $(P E D)^{33}$, que estabeleceu polos de ecoturismo em Goiás.

O PED elegeu quatro localidades para execução de suas propostas de ecoturismo: Alto Paraíso de Goiás, Pirenópolis, São Domingos e Três Ranchos. Essas localidades segundo Almeida (2002) eram estratégicas por já contarem com uma demanda turística real e estarem próximos aos dois maiores centros urbanos do estado: Goiânia e Brasília.

Apesar desta "vocação turística", de acordo com a autora, estas

\footnotetext{
${ }^{32} \mathrm{O}$ acidente com o Césio 137 ocorreu em 13/09/1987 na cidade de Goiânia, e é considerado o maior acidente radioativo do Brasil e o maior do mundo ocorrido fora das usinas nucleares. $\mathrm{O}$ desastre fez centenas de vítimas, contaminadas devido às radiações emitidas por uma única cápsula que continha a substância.

${ }^{33}$ Entre 1994 e 1998, o Ministério do Meio Ambiente em sua política nacional, implementou o PED em diversas cidades do país. As cidades eleitas em Goiás foram Pirenópolis, Cidade de Goiás, Três Ranchos e São Domingos, o que segundo Almeida (2010), acabou por consolidar uma situação já existente, evidenciando as desigualdades entre os municípios em que o turismo merecia ser investido, daqueles municípios desprovidos de atrativos potencialmente turísticos e/ou, onde a administração municipal não investia suficientemente nesta atividade.
} 
localidades careciam de "uma ampliação da infraestrutura turística receptiva e da captação de recursos humanos". Todavia, com o fim dos recursos do PED "encerrou-se definitivamente o projeto" (ALMEIDA, 2002, p.209). Outro problema enfrentado pelo programa foi, conforme a autora, a mudança nas administrações públicas nestes locais, já que os novos prefeitos não cumpriram com os compromissos assumidos pelos seus antecessores. Para Almeida (2002) essa realidade foi mais grave no município de Pirenópolis.

Entretanto, O PED deixou para trás como saldo positivo, entre outros, Centros de Atendimento ao Turista (CAT's); 1.153 pessoas qualificadas em diversas áreas estratégicas para o desenvolvimento do turismo; implantação de programas de educação ambiental; inventários de oferta turística, entre outros.

No entanto, de forma geral os objetivos do programa não foram alcançados, de acordo com Almeida (2002) devido à "falta de responsabilidade compartilhada por todos os agentes sociais, governamentais e não governamentais". (ALMEIDA, 2002, p.211). Embora em nível municipal tenha ocorrido o esfriamento das ações em prol do turismo, como explicitou Almeida (2002), no que se refere às políticas estaduais estas persistiram por mais tempo. Essa permanência só foi possível graças às parcerias, principalmente com o SEBRAE. Entre outros objetivos figurava o diagnóstico de potenciais turísticos no estado, além de consultoria, treinamento e reciclagens.

Segundo a autora, o SEBRAE teve papel fundamental no desenvolvimento turístico do estado. Em Pirenópolis, o SEBRAE em parceria com a Agetur promoveram o Planejamento Estratégico da "Cadeia Produtiva" de Turismo, selecionando como "principais desafios a serem superados - os relativos à infraestrutura, à educação, ao marketing, à política de turismo e aos destinos turísticos" (Almeida, 2002, p.213).

Outra ação de destaque da década foi a realização do Programa Nacional de Municipalização do Turismo (PNMT), bem como a atuação do Serviço Brasileiro de Apoio às Micro e Pequenas Empresas (SEBRAE) ${ }^{34}$, na promoção de

\footnotetext{
${ }^{34}$ Em Goiás, devido a convênios celebrados entre a EMBRATUR e o SEBRAE, as principais atividades da instituição foram: diagnóstico do turismo em Goiás, treinamento e reciclagem, consultorias às empresas, lançamento do Anuário turístico de Goiás (1997), realização em parceria com o Grupo Nativa, na realização de mais de sessenta inventários/ diagnósticos em propriedades rurais para expansão do turismo rural; planejamento estratégico da cadeia produtiva do turismo em Pirenópolis, entre outras ações.
} 
diversas atividades correlatas ao turismo. O Programa Nacional de Municipalização do Turismo, no estado de Goiás, incorporou 78 municípios, entretanto, de acordo com Almeida (2002) o programa não conseguiu atingir seus objetivos em Goiás, devido a diversos fatores: falta de atuação do Conselho Estadual de Municipalização do Turismo; à metodologia de implantação que esbarrou nas limitações financeiras dos municípios, e, à política partidária, que muitas vezes é contrária aos interesses da coletividade, situação que não era muito diferente dos municípios dos demais estados da federação, conforme pode ser averiguado em Beni (2006). Em 1999, passaram a serem elaborados os Planos Plurianuais (PPAs), respondendo às exigências constitucionais; 0 primeiro PPA foi criado na gestão de Marconi Perillo, denominado de "Plano Estratégico Goiás Século XXI", o plano tinha como propósito tornar Goiás "competitivo" e transformar o estado em um polo econômico regional. Nesse PPA, ao turismo foram destinados $0,75 \%$ do orçamento estadual, esse percentual serviu para desenvolver a infraestrutura básica nas regiões de polo turístico, com a construção de aeroportos e pavimentação de rodovias, ou seja, o orçamento destinado ao turismo foi direcionado para obras públicas, o que poderia ser feito com o orçamento da Secretaria Estadual de Obras.

Diversas reformas administrativas foram realizadas em 1999, e no que se refere ao turismo, houve a extinção da Goiastur e a criação da Agência Goiana de Turismo, atual Goiás Turismo, uma autarquia criada pela lei 13.550 de 11/11/99. No inicio era denominada AGETUR, (o que foi alterado em 2008 devido às reformas administrativas), essa autarquia possui autonomia administrativa, financeira e patrimonial e está jurisdicionada à Secretaria da Indústria e Comércio e em princípio tinha como missão "fortalecer o turismo, intensificar sua contribuição para a geração de divisas e ampliar o mercado de trabalho, assim como propiciar a elevação do padrão de bem-estar social, a integração nacional e a valorização do patrimônio natural e cultural" (ALMEIDA, 2002, p. 218).

Ocorreram importantes progressos no turismo em Goiás nesse período, dentre4 eles merecem destaque: o reconhecimento da Cidade de Goiás como Patrimônio da Humanidade, chancelada pela UNESCO; consolidação do Festival Internacional de Cinema e Vídeo Ambiental (FICA); Festival de Cinema 
de Porangatu; as largadas do Rally dos Sertões em Goiânia (2002 a 2012); a construção do Cavalhódromo em Pirenópolis; consolidação do Festival Canto da Primavera (um festival de música que tem foco na promoção de músicos goianos, bem como oficinas de instrumentos musicais e palestras).

Uma conquista a ser ressaltada dessa década, foi criação da primeira versão para a regionalização do turismo no estado (uma parceria entre o SEBRAE-GO e a AGETUR em 2001), instituindo quatro regiões para trabalhar a atração de investimentos e turistas, intitulados de "Caminhos de Goiás ${ }^{35}$ ", dividiam o estado em quatro polos: Caminho do Sol, Caminho das águas, Caminho do Ouro e Caminho da Biosfera, Pirenópolis era integrante do Caminho do Ouro, junto a mais outros quatro

municípios.

É também na primeira metade da década de 2000, que o governo estadual implantou um novo programa de desenvolvimento do estado, denominado de "Goiás, Século XXI", no que tange ao turismo, tinha por objetivo efetivar ações públicas em prol do desenvolvimento turístico, principalmente no que diz respeito à implantação de infraestrutura básica e turística. Esse programa fazia parte de uma política pública maior quem em nível federal era chamado de "Brasil em ação". (Almeida, 2002). Coincidência, ou não, nesse período o município de Pirenópolis experimentou o "boom turístico", momento em que passou a haver a implantação de mais empreendimentos para atender á crescente demanda de turistas.

Em 2006, outra política pública implementada no estado em prol do "desenvolvimento turístico", também proveniente de uma política federal, foi o projeto "Brasil, Meu Negócio é Turismo", foi uma realização do Ministério do Trabalho com parceria com outras instituições: Fundação Unitrabalho e Fundação Roberto Marinho e Ministério do Turismo. O projeto tinha por objetivo selecionar e formar instrutores na área de qualidade em atendimento à clientela turística. Posteriormente esses instrutores deveriam atuar como difusores desse conhecimento adquirido junto à população de seus municípios. A justificativa

\footnotetext{
${ }^{35}$ Caminhos de Goiás" foi uma estratégia criada pela AGETUR - em consonância com o PPA (20042007) - que tinha como objetivo promover o estado em âmbito regional, nacional e internacional, e, implementou as seguintes ações: promoção e divulgação do Estado; Programa de informação e inteligência turística; Programa de infraestrutura turística; Planejamento Integrado da Pesquisa Turística, dentre outras.
} 
apresentada para a realização deste projeto era pautada na concepção de que a atividade turística destaca-se pelo grande desempenho na criação de postos de trabalho e renda. A principal exigência para a realização do curso era "conhecimento da realidade local e das possibilidades de desenvolvimento do turismo na sua cidade de origem". No estado de Goiás o projeto foi aplicado nos municípios de Alto Paraíso, Pirenópolis e Caldas Novas. Vale ressaltar que em nível municipal, as políticas públicas de incentivo ao turismo em Pirenópolis têm oscilado bastante de acordo com a troca de mãos do governo municipal.

Alcides Rodrigues foi o governador de Goiás entre os anos de 2007 a 2010, e implementou em sua gestão o PPA (2008-2011), e no tocante ao turismo, o objetivo era o aumento das receitas de serviços, sobretudo dos serviços atrelados ao turismo. Diversos programas foram executados, como o Programa de Identificação e Desenvolvimento Turístico, que tinha como objetivo identificar as potencialidades e as necessidades dos municípios e da atividade turística, a fim de subsidiar as ações específicas de desenvolvimento dos destinos turísticos; Fomento à Qualificação e Capacitação em Turismo; Programa Mostra Goiás, em que o objetivo era a promoção do estado em nível regional, nacional e internacional; Programa de Desenvolvimento Sustentável do Nordeste Goiano Nordeste Novo, o objetivo desse programa era corrigir as distorções e os desequilíbrios da região nordeste goiano, integrando-a as demais regiões do estado, impulsionando o setor produtivo através das potencialidades existentes visando à geração de emprego e renda e melhoria da qualidade de vida da população, e uma das potencialidades dessa região é o turismo, sobretudo devido ao Parque Nacional da Chapada dos Veadeiros e seu entorno, com grande biodiversidade.

A política pública do turismo em Goiás tem um marco nesse período com o lançamento do primeiro - e único até o presente momento - Plano Estadual de Turismo de Goiás - "Goiás no Caminho da Inclusão" (2008-2011). Concebido no ano de 2007, esse plano foi elaborado aos moldes do Programa Nacional de Regionalização, o planejamento foi desenvolvido sob a ótica regionalizada, com vistas à integração das cidades de uma mesma Região Turística, que possuam atrativos turísticos similares com potencial para a criação de novos destinos e a composição de roteiros turísticos regionais. Logo, a política instituída anteriormente, denominada que "Caminhos de Goiás", que estabelecia quatro 
caminhos para o desenvolvimento do turismo, fora substituída por Nove Regiões Turísticas, perfazendo um total de 46 municípios, denominadas: Região Agroecológica, Região das Águas, Região Vale do Araguaia, Região do Vale da Serra da Mesa, Região dos Engenhos, Região das Nascentes, Região dos Negócios, Região da Reserva da Biosfera de Goyaz e Região do Ouro.

FIGURA 1: Programa de Regionalização do Turismo Mapa das Regiões Turísticas de Goiás

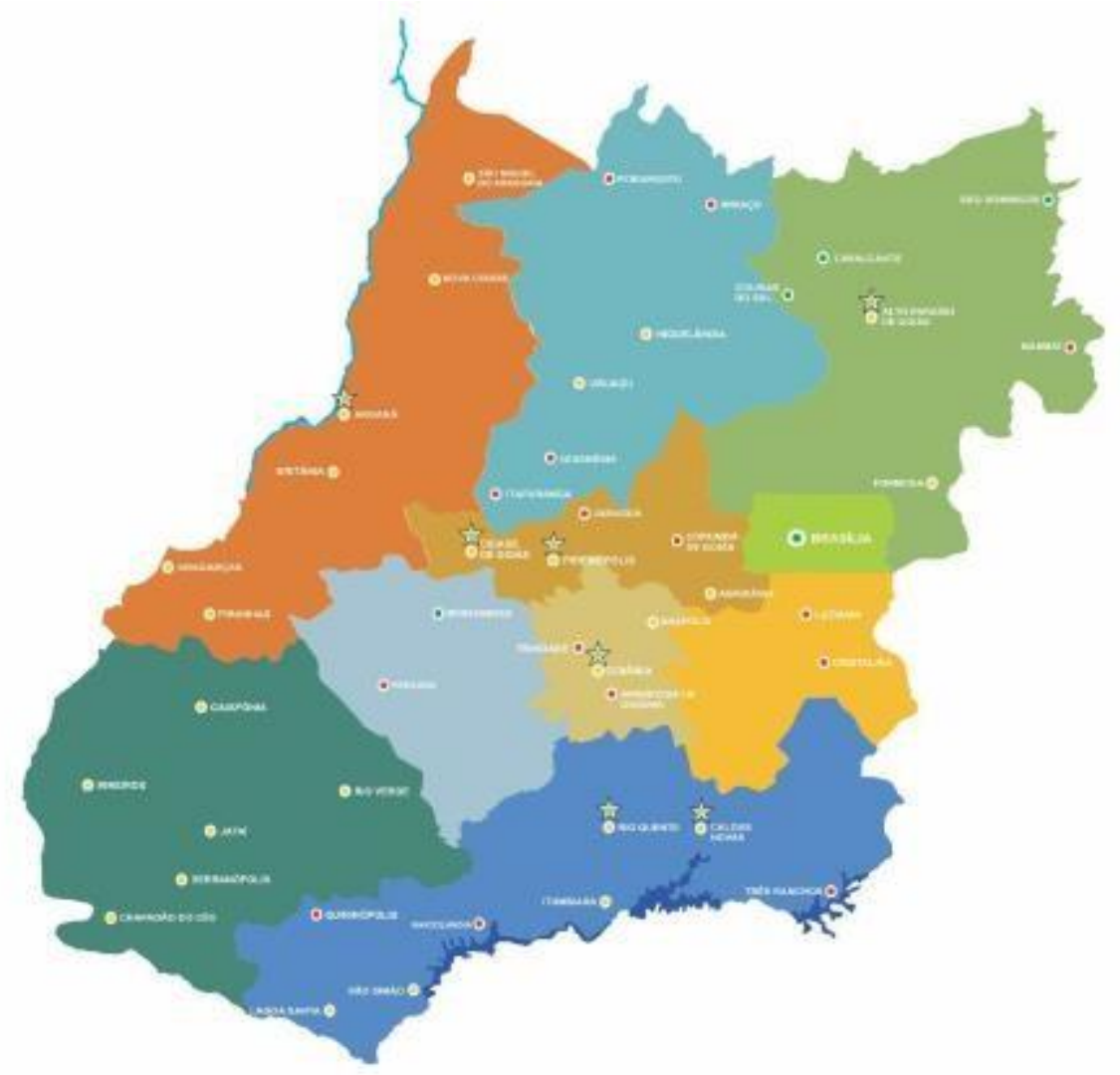

\section{LEGENDA}

\begin{tabular}{|l|l|}
\hline Região Agroecológica & Região dos Engenhos \\
Região do Vale do Araguaia & Região das Águas \\
\hline Região do Vale da Serra da Mesa & Região Nascentes \\
\hline Região da Biosfera de Goyaz & Região do Ouro \\
\hline Região dos Negócios & \\
\hline
\end{tabular}

Fonte: Plano Estadual de Turismo, 2008. 
A lógica dessa nova divisão ou regionalização seguiu a mesma que a anterior, no entanto, nesse momento ela fora formulada pela Goiás Turismo com parceria do Ministério do Turismo, SEBRAE e o Serviço Nacional de Aprendizagem Social (SENAC). O Programa de Regionalização do Turismo promoveu a delimitação geográfica em regiões turísticas para fins de planejamento e a definição de estratégias e gestão, com a finalidade de gerar a integração e a articulação Inter setorial e a cooperação entre os participantes da "cadeia produtiva" regional, o estado seguiu as diretrizes desse programa para a elaboração de seu Plano.

Seguindo o modelo do Plano Nacional e diretrizes do Programa de Regionalização, a partir de 2004, cada sub-região goiana passou a ter uma instância de governança regional própria, denominada de "Fórum Regional de Turismo".

Com o objetivo de criar uma capilaridade e maior aproximação do estado junto aos municípios turísticos, a Goiás Turismo implementou em 2007 uma estratégia para tal intento, e seguindo a mesma do Ministério do Turismo junto aos Estados, delegou um interlocutor em cada uma das nove regiões turísticas. $O$ interlocutor ${ }^{36}$ era uma pessoa residente na região em que atuava e tinha como função principal, realizar a interlocução entre os municípios da região e a Goiás Turismo, o objetivo da interlocução era de "aproximar, de apoiar, colaborar e fortalecer o desenvolvimento turístico local/regional"; diversas ações eram realizadas nesse sentido, como: levar as demandas desses municípios à Instituição, e vice-versa; promover a articulação entre os municípios integrantes da região, bem como dos atores envolvidos no processo; participar e apoiar a instância de governança regional, dentre outras ações; essa estratégia permaneceu vigente até 2010.

Dentre as nove regiões turísticas de Goiás, quatro municípios foram elencados para fazer parte do Programa Federal denominado "65 Destinos Indutores". O município de Pirenópolis, que faz parte da Região do Ouro, integra esse quadro de destinos indutores do estado de Goiás, e desde 2008, tem recebido o estudo de competitividade.

A figura 2 ilustra o mapa da região do Ouro e os municípios integrantes.

\footnotetext{
${ }^{36}$ A autora da dissertação fora interlocutora da Região do Ouro entre os anos de 2007 a 2009.
} 
FIGURA 2: Região do Ouro - Pirenópolis

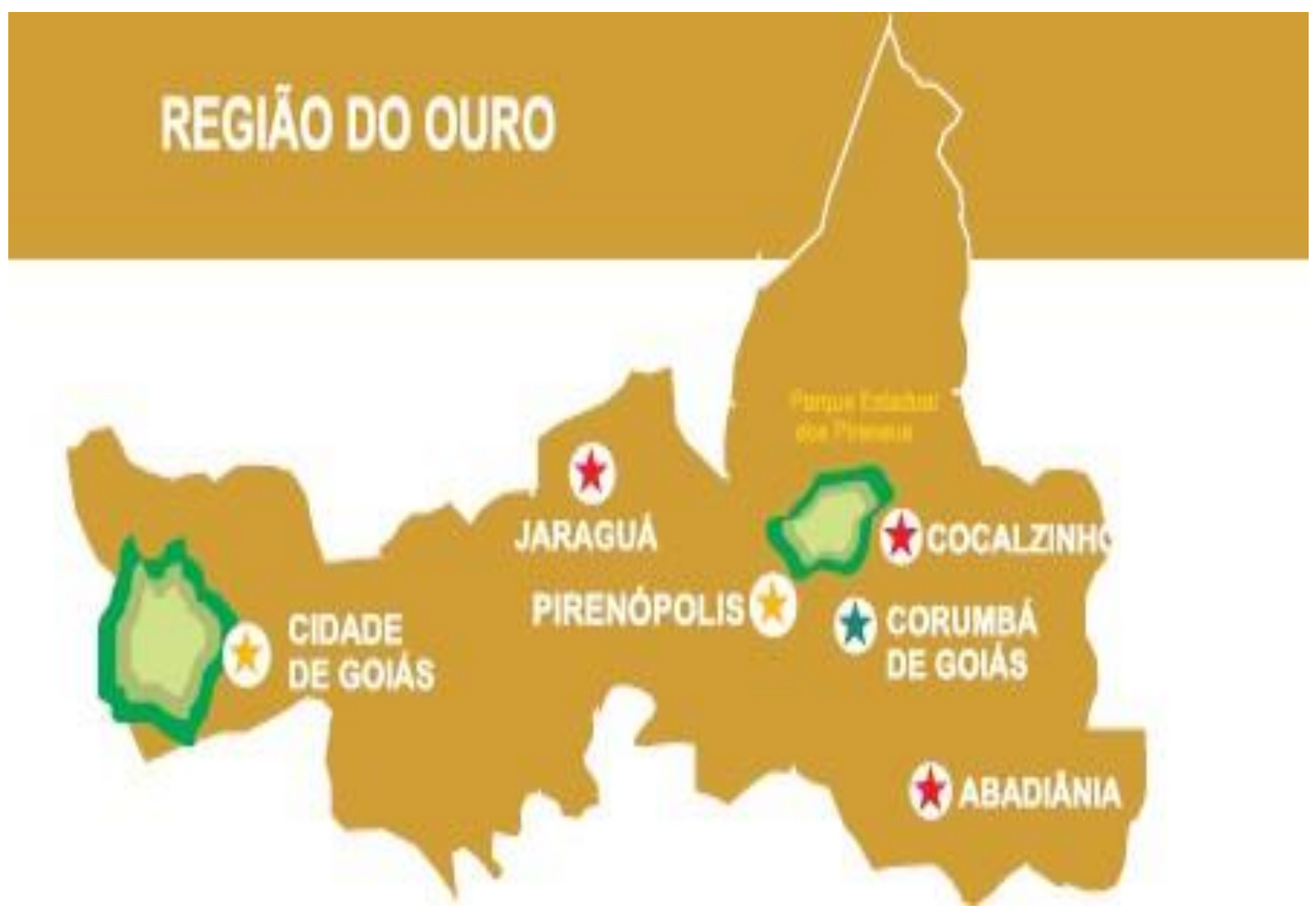

Fonte: Plano Estadual de Turismo, 2008.

Além desses municípios destacados no mapa acima, integra essa região atualmente, o município de Alexânia, que tem diversos hotéis na área rural e é conhecido pelo artesanato de móveis em madeira e pela "feira do troca", uma feira de trocas que acontece anualmente, que atrai pessoas de diferentes lugares de Goiás e de Brasília.

A partir de Novembro de 2013, o mapa da regionalização de Goiás foi alterado, ganhando uma nova região, perfazendo um total de 10 regiões e 51 municípios, algumas regiões foram também renomeadas, e atualmente é formado pela seguinte configuração: Região Agroecológica, Região das Águas, Região Vale do Araguaia, Região do Vale da Serra da Mesa, Região do Ouro, Região dos Lagos e Cristais (antiga Região do Engenho), Região dos Lagos (antiga Região das Nascentes), Região dos Negócios e Tradições (antiga Região dos Negócios), Região da Chapada dos Veadeiros (antiga Região da Reserva da Biosfera de Goyaz), e a nova região, denominada de Região das Grutas e 
Cavernas, que fazia parte da antiga Região da Biosfera de Goyaz.

FIGURA 3: Mapa da Regionalização de Goiás - 2013.
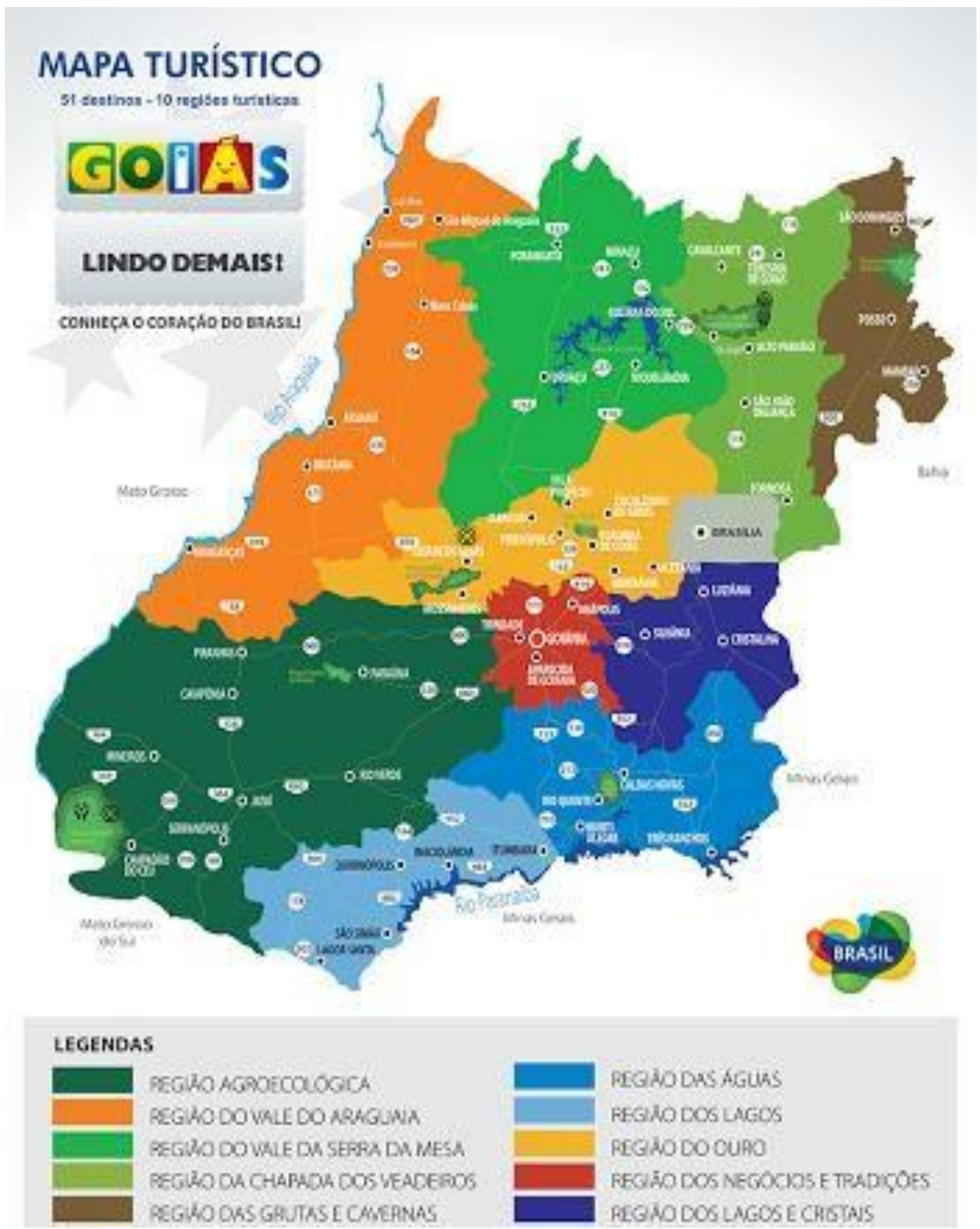

PIGHODAS AGURS

FEGLWO DOS LAGCS

REGAO DO CUAO

FECI FO DOS NECOCIOS E TPADYOOES

RLGIO DOS LAGOS E CHETAIS

Fonte: Goiás Turismo, 2014. 
O Plano Estadual de Turismo traz a indicação de seu Sistema Estadual de Turismo, conforme a figura 4:

FIGURA 4: Sistema Estadual de Turismo

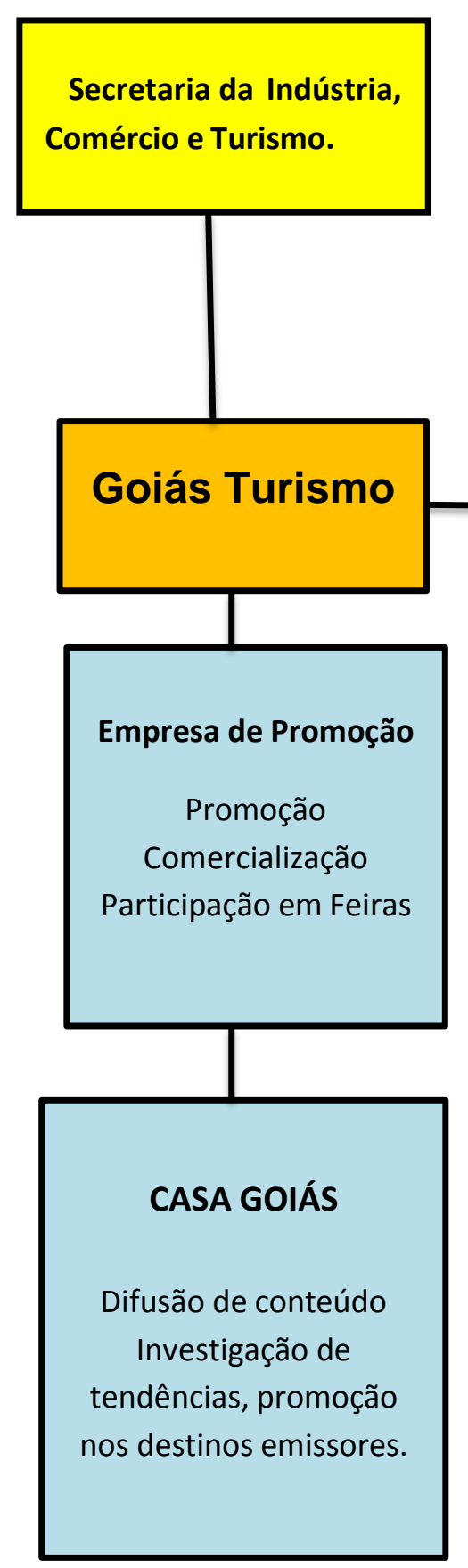

Instituto de

Estatística e

Pesquisa Turística

de Goiás

09 Coordenações

Regionais

\section{Comissão de Promoção do}

Turismo de Goiás

Comissão Estadual de

Turismo

Goiás Turismo

Planejamento

CELG

Fazenda

Fórum Estadual de

Turismo

09 Fóruns Regionais

Espaço de colaboração entre as administrações públicas e os atores do setor privado para a definição de políticas públicas e definição de prioridades e acompanhamento do Plano de Desenvolvimento Turístico.

Fonte: Plano Estadual de Turismo, 2008. 
Cabe destacar que a criação do Instituto de Pesquisas Turísticas (IPTUR ${ }^{37}$ ) e o Observatório do Turismo ${ }^{38}$, ocorrem nesse período. O Instituto é uma diretoria ligada a Goiás Turismo, e tem como objetivo implantar um sistema de informação turística baseado na organização e geração de dados, análises e estudos estratégicos de forma continuada, abarcando diversas áreas de atuação no que tange a informações turísticas.

Outro destaque que cabe ao Plano Estadual de Turismo (PET) é uma estratégia que foi elaborada e realizada com vistas a estimular a integração de destinos e regiões turísticas, ampliando a competitividade turística do Estado.

Trata-se de um "modelo que se utiliza de um sistema de classificação dos municípios turísticos, que tem por finalidade, identificar o nível de desenvolvimento e direcionar apoio técnico e financeiro". (PET, 2008, p.6). Para tal classificação foram estabelecidos os seguintes critérios, baseado na Política Nacional de Turismo: 1) Existência de Conselho Municipal de Turismo; 2) Existência de Fundo Municipal de Turismo; 3) Realização do Inventário da Oferta Turística; 4) Elaboração do Plano Municipal de Turismo; 5) Número de leitos disponíveis; 6) Centro de Atendimento ao Turista em operação; 7) Número de cadastros de prestadores de serviços turísticos e 8) Número de meios de hospedagem que enviam Boletins de Ocupação Hoteleira. Alguns ajustes houveram após a implantação desse modelo, e foram ainda adicionados como critérios (que não constam no PET): a adesão ao Instituto de Pesquisas Turísticas (IPTUR) e participação no Fórum Regional, além de práticas sustentáveis adotadas pelo município.

Dentre cada um desses critérios, pontos foram atribuídos e, então, aqueles municípios que apresentaram mais de 20 pontos em sua somatória geral, foram certificados pela Goiás Turismo como município Cristal (contemplado com apoio

\footnotetext{
${ }^{37}$ O Instituto de Pesquisas Turísticas de Goiás - IPTUR, criado em 2009, é constituído através da parceria entre a Goiás Turismo e os principais destinos turísticos do estado, com o apoio do Serviço Brasileiro de Apoio às Micro e Pequenas Empresas de Goiás (SEBRAE/GO), a Associação Goiana de Municípios (AGM) e Instituições do Ensino Superior do Estado de Goiás.

${ }^{38}$ O Observatório do Turismo de Goiás, desenvolvido pela Faculdade de Tecnologia SENAC Goiás em parceria com a Goiás Turismo, á um espaço virtual direcionado a gestores, profissionais e acadêmicos do setor turístico e tem como o objetivo reunir e disseminar dados, estudos e informações relevantes sobre o turismo no Estado de Goiás. Com este objetivo pretende preencher a lacuna existente na organização e disponibilização de dados e informações turísticas existentes, facilitando o seu acesso e uso pelo público interessado.
} 
na sensibilização, mobilização da comunidade no incentivo à criação do Conselho Municipal de Turismo e realização da Pesquisa de Inventário da Oferta Turística); com total acima de 40 pontos, município Esmeralda (contemplado com ações de qualificação do destino, ações de estruturação e organização de produtos e roteiros turísticos e a transformação de recursos potenciais em atrativos turísticos) e, por fim, acima de 60 pontos, como município Diamante (contemplado com ações de promoção, divulgação e apoio em eventos). Posteriormente foi instituído mais um nível de classificação, o Destino Mais, para que o município atinja essa classificação, deve ter acima de 100 pontos, tem que apresentar práticas de sustentabilidade ${ }^{39}$, de acordo com os critérios estabelecidos no documento Qualifica Goiás (sendo contemplado com estudo de marketing, prioridade na promoção nacional e internacional, folhetaria bilíngue, priorização de investimentos em infraestrutura e monitoramento dos impactos da atividade turística). O município de Pirenópolis é classificado como Diamante atualmente.

Embora esse sistema de classificação seja interessante, no sentido de que estimula os municípios a se estruturar e se organizar, para que recebam apoio de acordo com o seu estágio de maturação, há que se relativizarem as benéfices. Pois, esse mesmo sistema pode criar uma corrida frenética por parte desses municípios para serem mais bem posicionados no "discurso", (melhorando assim a sua competitividade no cenário regional e estadual), que pode como consequência provocar um atropelamento de etapas em um processo de desenvolvimento que seja realizado de forma participativa, descentralizada.

A construção democrática social dá-se com avanços e retrocessos, uma vez que deve atender a diferentes demandas e interesses que nem sempre ocorrem no tempo que a competitividade e o capitalismo requerem, ademais, depende da maturidade da comunidade, da capacidade de articulação, de sinergia, da vivacidade ou apatia da comunidade, dentre outros fatores.

\footnotetext{
${ }^{39}$ O documento Qualifica Goiás define como práticas de sustentabilidade a ser implantadas: a apresentação de aterro sanitário nas cidades, rede pública de coleta de lixo, estação de tratamento de esgoto, política educacional municipal que contemple aspectos pedagógicos correlacionados ao turismo, meio ambiente e ao patrimônio cultural, política municipal de prevenção e enfrentamento a exploração sexual infanto-juvenil, implantação de Unidade de Conservação, meios de hospedagem com sistema de gestão socioambiental e, por fim, produção cultural associada ao turismo, como: manifestações culturais, festivais gastronômicos e artesanato que retrate e valorize a identidade cultural.
} 
No entanto a política pública e o planejamento, quando realizados de forma participativa e descentralizada de fato, são instrumentos importantes para um desenvolvimento do turismo que promova equidade, justiça social, respeitando a natureza, a cultura e garantindo os direitos civis, sociais humanos e cívicos, respeitando as diferenças, tanto dos turistas, como dos indivíduos e da comunidade receptora.

\section{CAPÍTULO II . CONSIDERAÇÕES TEÓRICO-METODOLÓGICAS}

Considerando o cenário de questões, tanto objetivas quanto subjetivas que envolvem o objeto de estudo, para nortear a investigação elege se a aplicação do método dialético histórico estruturalista, este, que significa esforço para apreensão do singular em seus limites/ possibilidades e contradições/ mediações articulados à totalidade mais ampla.

De acordo com Demo (2000), esta abordagem interpretativa busca a mediação entre o objetivo e o subjetivo da realidade social, onde o ponto próprio da dialética é o horizonte da historicidade, por isso o autor classifica que só é tratável dialeticamente, o fenômeno tipicamente histórico. O que justifica a escolha do método para análise do objeto alvo desta investigação: os limites $e$ possibilidades de desenvolvimento pelo turismo e a transformação das práticas socioeconômicas de Pirenópolis/GO, uma vez que esta análise busca em suas raízes históricas o entendimento para os processos da realidade instaurada, pois o intuito é ir para além da aparência fenomênica, apreendendo sua essência, ou seja, a estrutura e dinâmica do objeto.

As principais dimensões reveladas nas categorias a priori são: totalidade/fragmentação, teoria/prática, autonomia/dependência, criticidade/alienação, subjetividade/objetividade e contradição/mediação. Já as categorias a posteriori são: Turismo, Políticas Públicas; Cidadania; Desenvolvimento Sustentável; Território; práticas sociais, e, Relações de Capital/Trabalho.

Essa pesquisa foi desenvolvida numa perspectiva dialética de autores, revendo a pertinência das categorias propostas, do método e das teorias, tendo como intuito investigar novas faces do fenômeno turismo, através de uma 
concepção interdisciplinar de conhecimento, no entanto, reconhecendo que todo conhecimento é parcial e limitado.

A escolha em se pesquisar o processo de expansão e de desenvolvimento do Turismo que ocorre no município de Pirenópolis, é justificada pelo considerável crescimento do fenômeno enquanto "atividade econômica", que denotou a necessidade em se estudar as possíveis transformações como uma prática social e seus efeitos na comunidade receptora com o intuito de que o conhecimento gerado a partir da interpretação da realidade possa se tornar um efetivo valor para a sociedade.

\subsection{CAMINHOS METODOLÓGICOS}

Esta investigação tem como lócus de pesquisa o município de Pirenópolis, situado no estado do Goiás; o recorte temporal da investigação proposta foi determinado entre os anos de 2003 a 2013, a escolha se deveu por ser o período em que se notou de forma mais acentuada um aumento do fluxo de turistas na cidade e investimentos privados, ademais deste englobar o estabelecimento de políticas públicas de forma mais efetiva, e, ser a época em que a pesquisadora esteve imersa na realidade do município, enquanto moradora, gestora pública e empreendedora.

Entretanto, cabe salientar que a análise valeu-se da compreensão histórica dos processos de usos e práticas do território em questão, uma vez que estes são essenciais para a compreensão da realidade contemporânea, sobretudo instaurada pelo turismo em uma concepção dialética materialista histórica.

A pesquisa é de tipo qualitativo, pois o intuito é de analisar a complexidade da realidade - que é dinâmica - como requer as ciências sociais, conforme constatado com Pedro Demo (2000):

A pesquisa qualitativa quer fazer jus á complexidade da realidade, curvando se diante dela, não o contrário como ocorre com a ditadura do método ou a demissão teórica que imagina dados evidentes. Fenômenos há que primam pela qualidade no contexto social, como (...) cidadania, felicidade, compromisso ético, e assim por diante, cuja captação exige mais que mensuração de dados. (DEMO, 2000, p.152).

Este tipo de pesquisa tem a preocupação com o processo e não simplesmente com os resultados, que são o produto desses processos. Ao ser 
escolhido o tipo de pesquisa qualitativa, a abordagem interpretativa adotada é a dialética materialista histórica, uma vez que o intuito da pesquisadora é ir para além da aparência fenomênica, apreendendo a essência, ou seja, a estrutura e dinâmica do objeto. No entanto a análise qualitativa da dialética histórico-estruturalista não nega a pesquisa quantitativa, mas vale se desses dados como aporte da análise da realidade, entretanto de forma alguma como principal ou único método, dessa forma a integração das dimensões qualitativa e quantitativa é um esforço metodológico em compreender a realidade.

A pesquisa é classificada como de nível exploratório, pois esta tem como principal finalidade desenvolver, esclarecer e modificar conceitos e ideias, tendo em vista a formulação de problemas mais precisos.

Sendo o intuito desta investigação, ir para além de se ter uma "visão geral do fenômeno", a necessidade de ser uma pesquisa também de nível explicativo faz se notória, pois esta tem como preocupação identificar e compreender os elementos que explicam a ocorrência e a forma do fenômeno, aprofundando o conhecimento da realidade.

O estudo de caso é adotado como forma de se observar os dados e fatos pertinentes ao tema dessa investigação, pois o objetivo da pesquisadora é a apreensão da totalidade da realidade, buscando renovar perspectivas existentes da mesma.

Este modo de investigação demonstra ser profícuo, pois o enfoque da pesquisa está sobre um fenômeno contemporâneo no contexto da vida real.

Segundo Bruyne et al (1977, p.224-225) o estudo de caso "reúne informações tão numerosas e tão detalhadas quanto possível com vistas a apreender a totalidade de uma situação". O estudo de caso nesta pesquisa possibilitou apreender o todo na parte, mas também o movimento inverso, ou seja, as partes do todo.

Em relação aos procedimentos, essa pesquisa tem seu foco nas análises bibliográfica e documental, bem como na pesquisa de campo com a condução de entrevistas semiestruturadas com pessoas fonte, como empreendedores, trabalhadores do turismo e gestores públicos.

O problema orientador dessa investigação é entender como o Turismo pode vir a ser um novo instrumento de transformação das práticas socioeconômicas no município de Pirenópolis rompendo ao continuísmo das 
tradicionais formas capitalistas de exploração do território.

Para responder ao problema de pesquisa proposto, tem-se como objetivo geral: analisar as relações de capital / trabalho no município de Pirenópolis e sua influência na caracterização do processo de desenvolvimento do Turismo local, desvelando os limites $e$ as possibilidades de um desenvolvimento sustentável e includente pelo turismo. Os objetivos específicos são:

a) Analisar se a políticas públicas do turismo implementadas no município contribuíram para um desenvolvimento sustentável e includente;

b) Identificar e analisar que tipo de desenvolvimento o turismo está propiciando em Pirenópolis;

c) Analisar se existe um continuísmo das tradicionais formas capitalistas de exploração do território em suas práticas de reprodução capital/trabalho pelo turismo no município.

O caminho metodológico foi construído a partir da triangulação de dados. A primeira etapa da triangulação consistiu-se na análise de conteúdo de diferentes documentos: elementos produzidos pelo meio, em que foram analisados documentos referentes ao planejamento do turismo como o Plano Nacional de Turismo nas versões (2003-2007); (2007-2010), e, (2010-2013), principalmente no que tange ao Programa de Regionalização do Turismo (PRT), e, o Plano Estadual de Turismo (2008); Plano Diretor do município vigente (2002), Plano Municipal de Turismo (2012), além da análise dos Índices de Competitividade (2008 a 2013).

A análise dos dados obtidos pela RAIS do Ministério do Trabalho e Emprego sobre os trabalhadores das Atividades Características do Turismo (de 2003 a 2013), bem como a análise dos dados fornecidos pela Prefeitura de Pirenópolis sobre os empreendimentos característicos da atividade turística embora não tenham sido analisados do ponto de vista de conteúdo, foram relevantes para a pesquisa dentro de uma perspectiva quali-quantitativa da realidade dos empreendimentos e trabalhadores do turismo.

$\mathrm{Na}$ segunda etapa foram analisados pela pesquisadora os processos e produtos, averiguando as percepções do sujeito (formas verbais), através de entrevistas com pessoas fontes do processo de desenvolvimento do turismo no município. Os critérios para a escolha dos entrevistados foram a participação nos processos de discussão e implementação do planejamento do turismo, englobando tanto gestores públicos quanto pessoas da sociedade civil, além dos 
sujeitos ativos que desenvolvem as atividades características do turismo: seus empreendedores e trabalhadores. Foram entrevistados: o gestor público á frente da Secretaria de Turismo, Planejamento Urbano e Desenvolvimento Econômico Sustentável; membros/empresários de associações representativas do turismo e empresários não

membros; e, trabalhadores do turismo, considerando as diferentes atividades do setor de serviços correlacionadas ao turismo. Após a realização das entrevistas, houve a análise de conteúdo das mesmas.

Como instrumento de interpretação da investigação, a análise de conteúdo foi escolhida por ser a mais adequada "para o desvendar das ideologias que podem existir nos dispositivos legais [...] que, à simples vista, não se apresentam com a devida clareza" (TRIVIÑOS, 1987, p.160-161). Trata-se de um conjunto de técnicas, que permite estudar as comunicações entre os sujeitos, colocando ênfase no conteúdo das mensagens, possibilitando inferência de conhecimentos relativos à mensagem analisada, seu conteúdo, seu contexto e seu sujeito produtor. A análise de conteúdo procura conhecer aquilo que está por trás das palavras sobre as quais se debruça; consiste na busca de outras realidades através das mensagens, trazendo á tona seus significados.

Nesse processo, foi possível evidenciar os itens básicos do roteiro de análise dos documentos/entrevistas, conforme esquema da figura abaixo:

FIGURA 5: Esquema do roteiro de análise dos documentos e entrevistas

\section{Contextualização da temática}

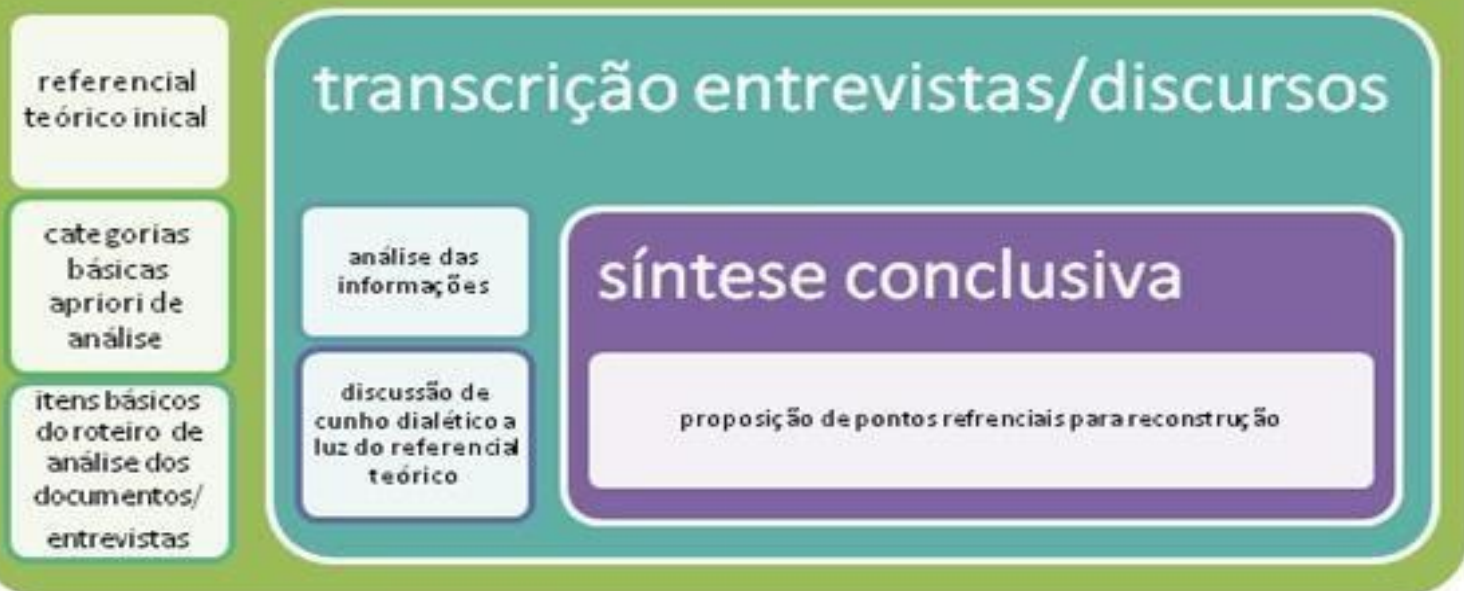

Fonte: Adaptado de Moesch (sala de aula 2013). 
A interpretação e a discussão por meio da análise de conteúdo dialético compreenderam os seguintes movimentos: a) leitura global exploratória com o objetivo de apreensão do todo nos documentos/entrevistas; b) leituras sucessivas para apreensão do todo em cada documento/entrevista; c) identificação dos temas, classificando-os em rubricas ${ }^{40}$ impregnadas de aspectos estruturais na busca de compreensão e interpretação; d) identificação dos indicadores potenciais dos temas para melhor sistematização das ideias; e) Análise dos trechos do discurso dos documentos/entrevistas; f) compreensão e estruturação dos discursos dos sujeitos sobre cada rubrica, expondo as ideiaschaves de forma sintética sem omitir aspectos reveladores; g) classificação dos discursos dos sujeitos em cada sub-rubrica - que são as categorias á priori - por meio da análise intradiscurso ${ }^{41}$.

E finalmente valendo-se da análise de conteúdo e por meio da contextualização temática a partir do referencial teórico, foi possível realizar a interpretação dos trechos do discurso dos documentos/entrevistas presentes nos quadros interpretativos. Esses apresentam os temas, as rubricas e seus indicadores de análise dos processos os quais são submetidos às categorias a posteriori da dialética, intituladas sub-rubricas, conforme modelo do Quadro 1.

\footnotetext{
${ }^{40}$ As rubricas são a identificação das unidades intencionais de discurso centradas nos temas.

${ }^{41} \mathrm{O}$ intradiscurso e o interdiscurso são conceitos desenvolvidos pelo teórico Michel Pêchaux sobre a dinâmica do discurso na construção dos valores e das relações culturais, sociais e políticas. Pêcheux elabora uma teoria do discurso que pressupõe a existência de transversalidades e conflitos culturais no interior e no exterior dos discursos, que afetam os sujeitos desses discursos e o próprio sentido das palavras. Os conflitos subjetivos que nascem dessas diferenças discursivas são sempre o resultado de conflitos sociais coletivos determinados pela hegemonia política ou pelo poder capitalista enraizado na sociedade. A distinção mais imediata dos dois conceitos propostos por Pêcheux seria: o interdiscurso como o "discurso de um sujeito" e do intradiscurso como a matéria linguística, ideológica, literária, simbólica, pré-existente, uma espécie de imagem já conhecida de uma realização linguística que qualquer sujeito pode reconhecer (PÊCHEUX, 1986).
} 
QUADRO 1: Modelo utilizado para interpretação de trechos do discurso dos Documentos e das Entrevistas

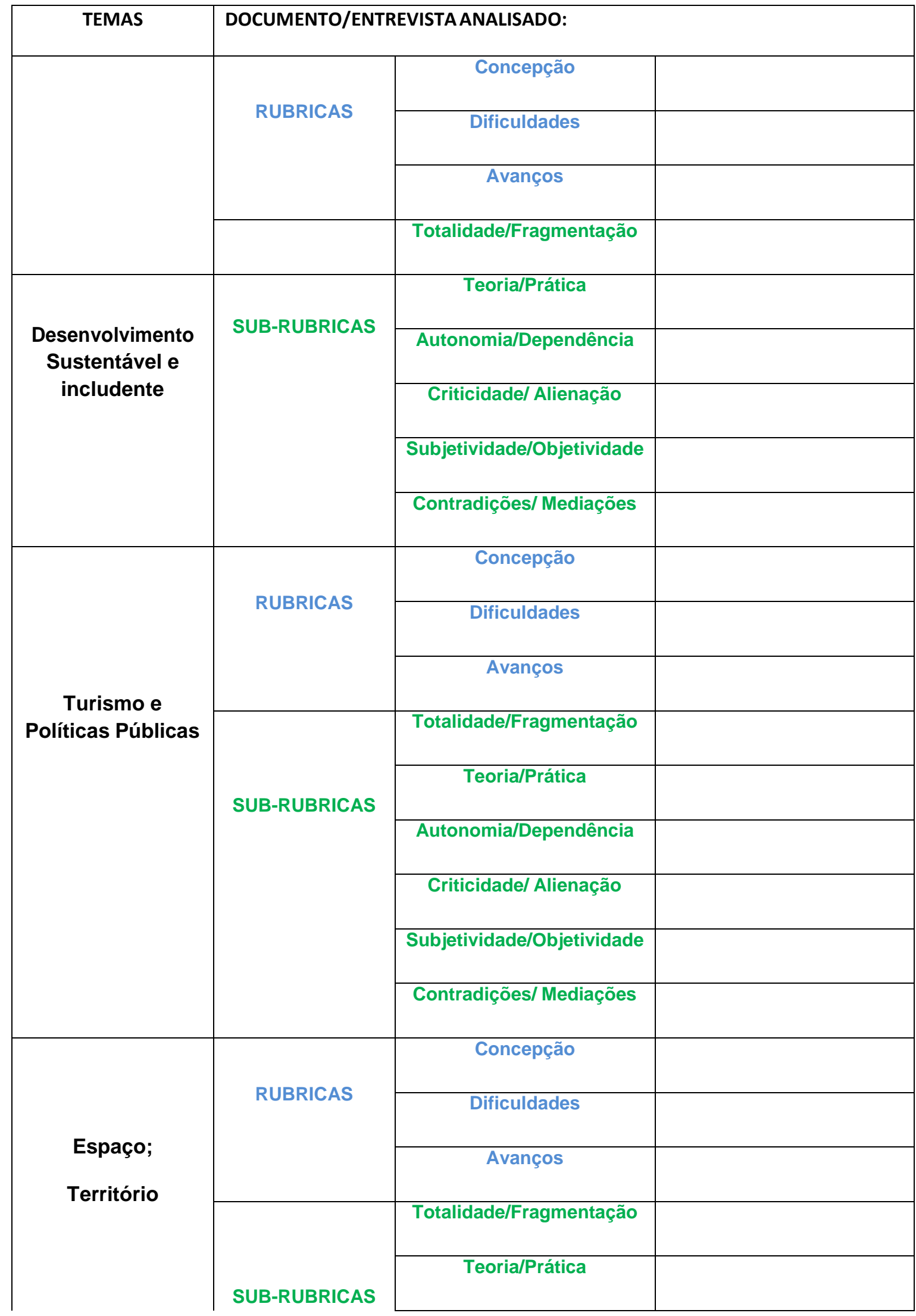




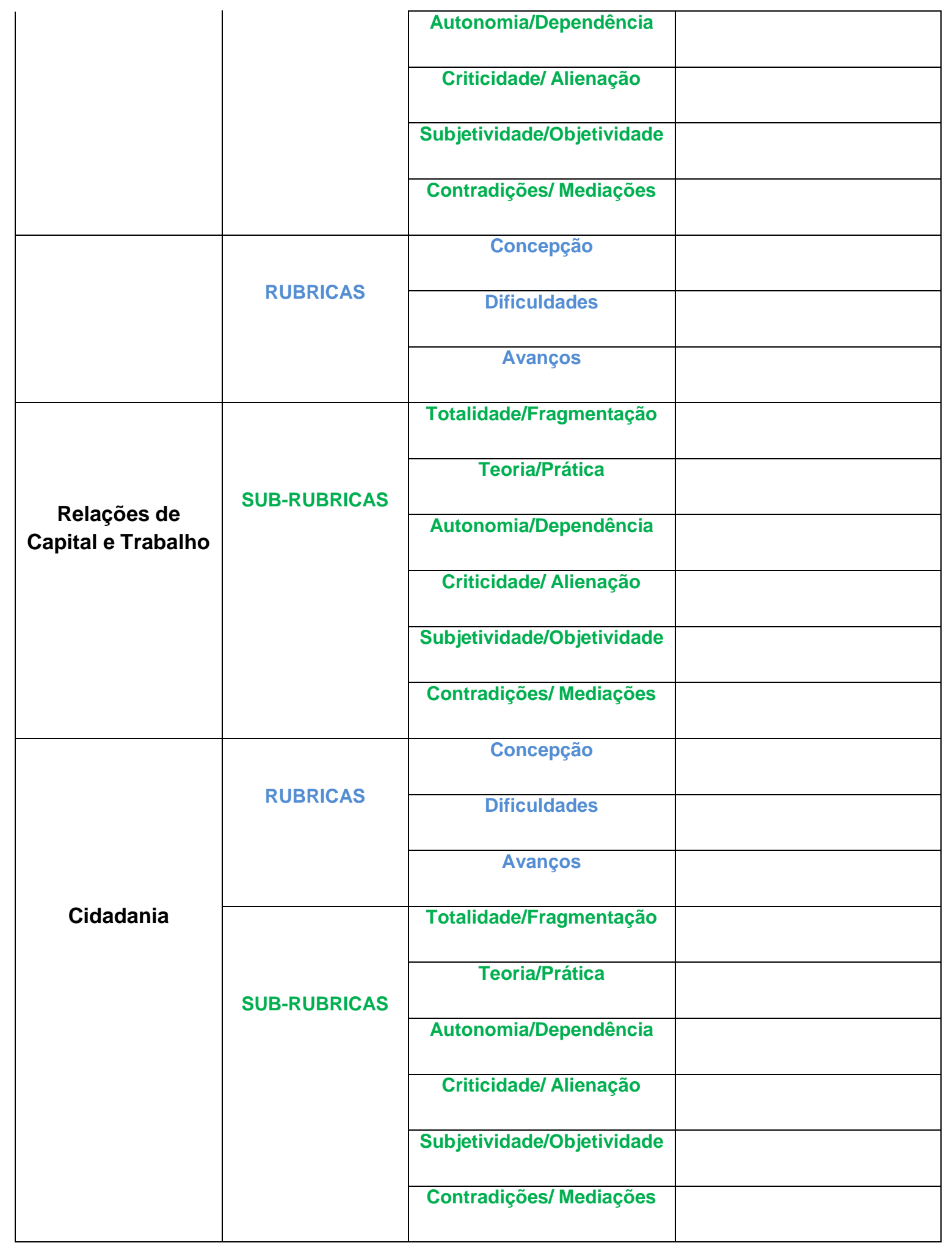

Fonte: Elaborado pela autora, 2014.

\section{Tema 1}

Desenvolvimento Sustentável e Includente 


\section{Rubricas}

Concepção de Desenvolvimento

Sustentável Responsabilidade com as

gerações futuras

Gerenciamento dos efeitos/impactos: cultural, ambiental, social e econômico.

\section{Sub-rubricas}

Indicador 1 - Existência de estrutura, legislação e fiscalização municipal de meio ambiente.

Indicador 2 - Compromisso com a melhoria da qualidade ambiental Indicador 3 -

Educação e conscientização ambiental e patrimonial

Indicador 4 - Gerenciamento dos efeitos sobre o meio ambiente e o patrimônio material cultural

Indicador 5 - Qualidade de vida da comunidade

Indicador 6 - Solidez e continuidade das parcerias e dos compromissos

estabelecidos entre os diversos agentes

Indicador 7 - Diversidade Cultural

Indicador 8 - Sustentabilidade Econômica

\section{Tema 2}

Espaço; Território

\section{Rubricas}

Concepção de espaço Concepção de território Uso dos espaços

\section{Sub-rubricas}

Indicador 1 - Práticas socioeconômicas desenvolvidas e as priorizadas Indicador 2 Delimitação (ou não) do uso dos espaços para a prática do turismo Indicador 3 Mecanismos de fiscalização do uso do espaço

\section{Tema 3}


Cidadania

\section{Rubricas}

Concepção de Cidadania

\section{Sub-rubricas}

Indicador 1 - Respeito aos direitos civis, políticos, cívicos, humanos.

Indicador 2 - Inclusão social

\section{Tema 4}

Relações Capital/Trabalho

\section{Rubricas}

Atividades Econômicas

Emprego e renda

\section{Sub-rubricas}

Indicador 1 - Incentivos (fiscais) ao empreendimento de atividades econômicas características do turismo

Indicador 2 - Geração de Emprego e Renda

Indicador 3 - Gerenciamento sobre o ciclo de vida de produtos e serviços

Indicador 4 - Investimentos na qualificação de trabalhadores do turismo

Indicador 5 - Garantia dos direitos trabalhistas

Indicador 6 - Fiscalização das normas dos direitos trabalhistas

\section{Tema 5}

Turismo e Políticas Públicas

\section{Rubricas}

Concepção de Turismo Concepção de Política Pública

\section{Sub-rubricas}


Indicador 1 - Planos

Indicador 2 - Programas

Indicador 3 - Projetos

Indicador 4 - Financiamento

Indicador 5 - Participação da comunidade na definição de ações e uso de financiamentos

Indicador 6 - Formalidade para gastos do dinheiro público

Indicador 7 - Relações com parceiros

Indicador 8 - Estímulo à participação e Inclusão de atores Indicador 9 Compromisso com o futuro do município Indicador 10 - Governança local (COMTUR)

Esta investigação acerca do processo de desenvolvimento do turismo no município de Pirenópolis buscou em sua tese, identificar as concepções de desenvolvimento ao longo dos tempos, para relacionar suas acepções ás práticas adotadas pelos sujeitos que atuam no turismo. Fez se uma análise acerca dos principais fatos e transformações que se deram no território ao longo do tempo, as ações públicas e civis no que concerne ás práticas turísticas no município para a posterior verificação empírica.

$\mathrm{Na}$ antítese, buscou-se identificar as situações que levaram o processo de desenvolvimento do turismo no município investigado ao seu modelo atual, ou seja, é a negação da tese, que se dá sobretudo pela reflexão a partir das situações teóricas e práticas presentes na tese.

Na síntese, propõe-se como nova tese a ser contestada, novas formas de percepção de desenvolvimento do turismo, as quais acarretam indicações de práticas que sejam capazes de reverter a situação vigente.

Para alcançar os objetivos propostos na pesquisa, este processo investigativo contou como metodologia para evidenciação empírica com a técnica da triangulação de dados. Para Triviños (1987), esta técnica tem por objetivo básico abranger a máxima amplitude na descrição, explicação e compreensão do foco em estudo, partindo de princípios que sustentam que é impossível conceber a existência isolada de um fenômeno social sem raízes históricas, sem significados culturais e sem vinculações estreitas e essenciais com uma macro realidade social.

Valer se da técnica de triangulação significa, nessa pesquisa, em primeiro lugar dirigir a atenção aos produtores do processo de desenvolvimento do 
turismo (o próprio modelo de desenvolvimento capitalista vigente), em seguida aos reprodutores (instituições), responsáveis por reproduzir por meio da política pública esses processos, ampliando-os de forma a torná-los verdades/modelos de desenvolvimento pelo turismo, e por último aos sujeitos que consomem esses processos como "verdades" (neste caso aos empreendedores e trabalhadores do turismo), dessa forma analisando os processos e produtos que são originados pela e na estrutura social, na qual ocorre o fenômeno turístico. Conforme ilustrado na figura que se segue:

FIGURA 6: Esquema da Triangulação

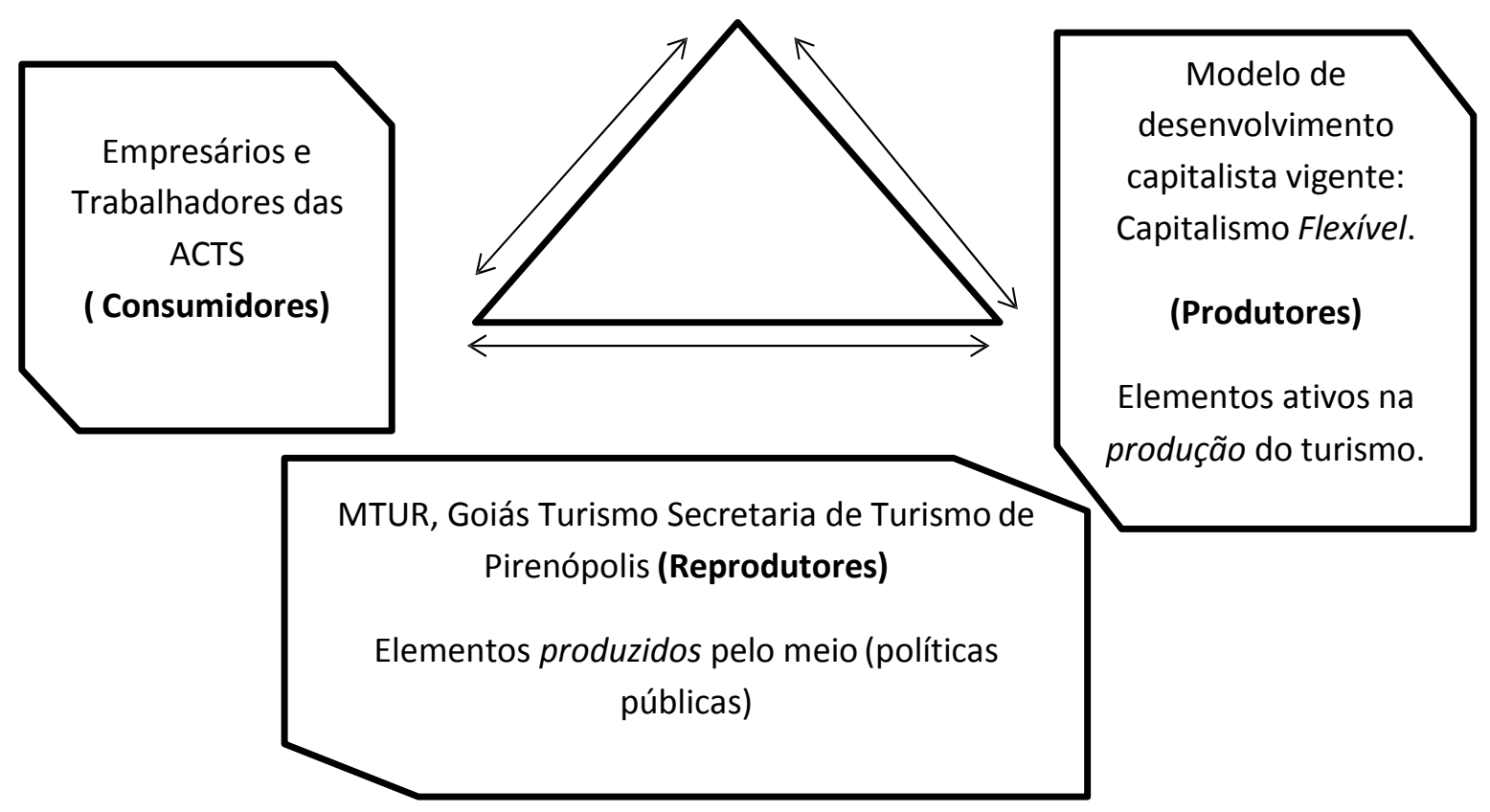

Fonte: Elaborado pela autora, 2015.

\subsection{A DIALÉTICA HISTÓRICO ESTRUTURAL (DHE) PARA A COMPREENSÃO DO PROBLEMA DE PESQUISA - CATEGORIAS ANALÍTICAS}

A dialética tem sua origem nos tempos áureos do pensamento filosófico com Platão (428 - 347 a.C) e Aristóteles (384 - 322 a.C). Em sua origem era entendida como a arte de discussão a partir de perguntas e respostas. Além desses pensadores, diversos outros influenciaram e contribuíram com a 
formação do pensamento dialético atual, dentre eles cabe destacar especialmente Hegel (1770-1831), a quem se deve a concepção moderna da dialética, que segundo Cheptulin (2004), sua genial contribuição para a dialética (dentre outras) foi a ideia de contradição que a realidade possui: de acordo com Hegel, tudo o que existe encerra em si uma contradição e essa contradição é a origem do movimento, o impulso da vida, no entanto, essa contradição não é eterna, e a um determinado estágio de desenvolvimento ela se resolve e se transforma.

Os pensadores Karl Marx (1818 - 1883) e Friedrich Engels (1820-1895), através de suas formulações teórico-metodológicas (materialismo histórico) também deram sua contribuição à dialética, entretanto, embora esses pensadores tenham sido expressivos para a construção do pensamento dialético, cabe ressaltar que não foram os únicos.

Considerando o pensamento dialético materialista, a realidade históricosocial diferentemente do pensamento positivista, é entendida como uma totalidade, na qual as partes (o econômico, o social, o político, o cultural, o ambiental, o coletivo, o individual, o local, o global, o objetivo, o subjetivo, etc.) só podem ser entendidas em uma relação com o conjunto, como articulação interna de todas as múltiplas relações; todos os fenômenos da realidade se encontram em um estado de correlação e interdependência universais.

Inspirada na dialética Hegeliana, a dialética pode ser descrita de forma sucinta, de acordo com o seguinte movimento: tese (primeiro momento) se afirma o que se vê, o que se sente e o que se percebe, o que está aparente. $\mathrm{Na}$ antítese (segundo momento) se nega o momento, através da análise das múltiplas determinações essenciais que se escondem sob a aparência das coisas e dos fenômenos. E, por fim, na síntese (terceiro momento) do processo dialético se chega à totalidade concreta, superando os momentos anteriores a partir da resolução dos opostos. A síntese é a construção da possibilidade do "novo".

De acordo com Demo (2000) o movimento dialético seria o seguinte:

Chamamos de tese a toda a formação vigente, que, sendo unidade de contrários, gera seus contrários, ou seja, antíteses. Estas, tornando-se prevalecentes, acarretam nova síntese. Por sua vez, toda síntese é apenas a próxima tese, que, de novo, vai gerar seus contrários. (DEMO, 2000, p.109). 
Compreendendo esse movimento, necessário faz se esclarecer que quando a antítese é mais profunda, ela coloca em contestação o todo, que resulta em "revolução" da realidade, ou seja, síntese na qual predomina o novo, em que há a quebra de paradigmas. Quando a antítese é menos profunda, ela coloca em contestação apenas parte do todo, o que resulta em uma "reforma", na qual se mantém o todo, porém em outra fase reformada. No entanto cabe ressaltar que esse processo de mudanças não se dá de forma linear, havendo avanços e retrocessos ao longo do mesmo.

A dialética possui algumas características próprias: considera a realidade como uma totalidade, como jogo de contrários, como um processo de mediação gradual da negação da negação. A dialética se opõe à ordem quantitativa estabelecida como norma, a forma de pensar não ocorre somente em cima da quantidade, mas passando gradualmente de um estado quantitativo para qualitativo. Cabe salientar que a dialética dialoga com a análise sistêmica; a principal convergência está na busca da apreensão da totalidade da realidade, pois diferentemente do postulado positivista, que determina que é a partir do estudo das partes se compreende o todo, na dialética há a investigação das partes e do todo, mas dentro de uma perspectiva sistêmica e complexa, de que o todo não é simplesmente formado pela soma de suas partes.

A dialética histórico-estrutural (DHE) como o termo já assinala, combina história e estrutura. Ela considera a história movida por formas - necessárias e independentes da vontade humana -, mas formas que fundam as transformações, o que permite dizer que o histórico é estrutural; ela capta as dissonâncias no esforço de compreender uma realidade complexa, de forma flexível, na expectativa de que o ordenamento menos rígido seja mais justo com a realidade.

Segundo Demo (2000, p.105), embora as mudanças possam ocorrer nas estruturas, a DHE, "aposta mais nas transformações históricas do que nas estruturais, ainda que os termos possam ser ambíguos". Por vezes, são chamadas de mudanças estruturais aquelas que são profundas, que vão até as raízes do fenômeno, mas, mesmo assim, trata-se do âmbito histórico, sendo impossibilitado de ser concebido sem sujeito. clarividente, porque em grande parte faz história de modo inconsciente, 
levado por razões que a razão desconhece, realizando o contrário do que planejara fazer, acertando sem querer e, por vezes, conquistando também o que bem queria que ocorresse. Sendo aberta, não concebe fim da história. Nisso, ao mesmo tempo em que preserva sua dinâmica, também a formaliza relativamente, porque tudo passa, mas a dialética como método, não. Para ser consentânea com realidade extremamente dinâmica, precisa dinamizar-se, flexibilizar-se, mas, no fundo, é rede formal para captar a realidade. (DEMO, 2000, p.106).

Considerando que toda formação histórica está em transição, e que toda realidade social é dinâmica, essa premissa atesta a existência de conflito social. Essa visão permite por um lado apresentar as diferenças nas organizações sociais, e, por outro identifica as contradições existentes que permitirão que dentro de um momento histórico-social, sejam formadas as condições do surgimento de uma nova fase, como por exemplo, a fase do mercantilismo e a fase do capitalismo.

Dessa forma, a DHE busca captar a dimensão intrinsecamente dinâmica da realidade objetiva e subjetiva, as posicionando em um mesmo patamar de importância. As condições objetivas da realidade seriam aquelas que são dadas externamente ao homem. Paulo Netto (2011), explica que as forças produtivas são o resultado da energia prática dos homens, mas essa mesma energia é circunscrita pelas condições em que os homens se encontram colocados, pelas forças produtivas já adquiridas pela forma social anterior, que não foi criada por eles, mas sim é produto da geração precedente.

Já as condições subjetivas seriam aquelas dependentes da capacidade dos homens de construírem a história em parte no contexto das condições objetivas, ou seja, mesmo dentro da circunstância material histórica que o homem nasce, ele pode interferir em seu destino e alterá-lo, através do uso que ele faz do conhecimento.

O tempo e o espaço, presentes na dialética, ocorrem na materialidade, sem que haja consciência de sua existência. O espaço, o tempo e a matéria em movimento estariam interligados. Seria a forma como o homem se relaciona com o mundo, designando a realidade objetiva pela reflexão de suas sensações, mas tal realidade objetiva existe independente dessas sensações. A matéria seria então a realidade objetiva, materializada nos sistemas sociais organizados na relação entre o homem, a sociedade e o meio.

A dialética também entende que a mente humana, complexa por natureza - uma vez que é razão e emoção - não consegue superar a realidade em sua 
totalidade, porque também sequer consegue superar a si própria. Por isso, a dialética histórico estruturalista (DHE) aposta na questionabilidade, inclusive como corretivo permanente de seus desacertos nas aproximações sucessivas; acredita na convivência de contrários, tanto na realidade quanto da mente humana.

\subsubsection{LEIS E CATEGORIAS ESSENCIAIS DA DIALÉTICA HISTÓRICO ESTUTURAL (DHE)}

As leis ou princípios mais relevantes do materialismo histórico dialético são: a lei da passagem da quantidade à qualidade, esta lei estabelece em primeiro lugar quais os mecanismos que atuam no processo de desenvolvimento das formações materiais; os objetos, os fenômenos se distinguem entre si devido á sua qualidade, ás suas propriedades. Já a quantidade é o grau de desenvolvimento ou de identidade das propriedades. De acordo com Triviños (1987):

(...) a passagem das mudanças quantitativas às qualitativas é uma lei geral do desenvolvimento do mundo material, (...) estas mudanças se realizam quando se rompem os limites da medida. (...) as mudanças quantitativas e qualitativas estão ligadas entre si e são interdependentes". (TRIVIÑOS, 1987, p.67-68).

Outra lei é a da unidade e da luta dos contrários, ou lei da contradição, de acordo com Triviños (1987), o desenvolvimento das formações materiais ocorre a partir dos chamados opostos e contrários, que estão em seu interior, entretanto sem desconsiderar a possibilidade de as forças externas também interferirem nos objetos.

Os contrários existem no desenvolvimento, enquanto os opostos se formam, a partir dos contrários, no processo de transformação, sendo que um não pode existir sem o outro, estando em permanente interação. Essa interação dos opostos é a contradição. A unidade dos contrários está no fato de a existência de um ser condição para a existência do outro.

A unidade de contrários é fonte motriz para a mudança, porque justamente é a possibilidade para que esta ocorra, é a partir de um movimento contrário que dá se início à superação de uma determinada situação. O poder é a mais típica unidade de contrário; historicamente é exercido por poucos, ou seja, a minoria e impacta a vida da maioria; os contrários excluem se e necessitam se, por 
exemplo, a classe burguesa detendo os meios de produção e explorando o proletariado, ao mesmo tempo depende deste para o seguimento de sua condição de classe burguesa.

Os contrários possuem ainda identidades semelhantes, mas também diferenças. As contradições podem ser internas ou externas, quando ocorrem em um mesmo fenômeno ou entre fenômenos, respectivamente, e básicas ou secundárias, que dependem da essencialidade do objeto.

O materialismo dialético "não somente reconhece a existência das contradições, mas acredita que a contradição é uma condição universal da existência da matéria" (CHEPTULIN, 2004, p.300). Por exemplo, para toda sociedade, a contradição entre produção e consumo é um fato.

Lei da negação da negação, essa lei da dialética é resultado da luta dos contrários, é objetiva e significa a passagem de um estágio superior a um inferior e vice- versa. No entanto, nem toda negação dialética significa a passagem de um fenômeno negado em seu contrário, "pode ocorrer no curso da negação dialética, de o fenômeno transformar se ou não em seu contrário, ou em qualquer outra coisa, superior em relação ao estado qualitativo anterior." (CHEPTULIN, 2004, p.315), por exemplo, a propriedade escravagista dos meios de produção, que é de natureza privada, segue com a mesma característica na propriedade feudal, ou seja, embora tenha mudado o tipo de sociedade, o caráter privado dos meios de produção, seguiu existindo, tanto na sociedade feudal como na sociedade capitalista, embora com outras características.

Em linhas gerais, a negação dialética é o resultado da evolução e da resolução das contradições próprias à formação material negada. A repetição sobre uma nova base, superior do que já foi transposto no curso da negação dialética, de acordo com Cheptulin (2004), constitui a essência da lei da negação da negação, o autor ressalta que esse processo de repetição sobre uma nova base pode ser feito não somente apenas por meio de duas negações como muitos autores defendem, mas sim que 0 número de negações é extremamente variável, podendo ocorrer diversas negações.

Cada negação é ao mesmo tempo destruição e criação, pois não há negação que destrua sem criar e vice-versa, a negação pode ser entendida como um processo evolutivo, para o marxismo, de acordo com Triviños (1987), essa evolução/desenvolvimento é encarado não como um processo retilíneo ou circular, 
mas sim como um processo que se dê em uma forma análoga a um espiral, em que cada volta dê a impressão de repetir a precedente, porém sobre uma nova base, mais elevada.

De acordo com Cheptulin (2004), o surgimento das categorias faz parte da história do conhecimento, o autor identifica algumas tendências na concepção de categoria: a primeira seria a realista; em que os filósofos considerariam que as categorias existem independentes da consciência humana, como essências ideais particulares; a segunda seria a tendência nominalista, em que seus pensadores concebem as categorias como ficção, ou seja, palavras que não designam a nada; a terceira seria a tendência kantiana, que seria o oposto da tendência realista, em que as categorias seriam formas próprias á consciência do homem.

$\mathrm{Na}$ concepção de Hegel, as categorias apareciam em decorrência do desenvolvimento da ideia, que existe anterior e independentemente da existência do mundo material, das coisas sensíveis. Para ele as categorias seriam as formas da atividade criadora da ideia, determinando a essência das coisas materiais. Hegel interpretava a natureza das categorias no plano do idealismo objetivo, revelando assim a sua tendência idealista de visão de mundo.

Essa concepção idealista da natureza das categorias foi criticada por Marx e Engels - embora sem deixar de reconhecer o mérito de Hegel na elaboração da dialética - Marx e Engels colocaram a dialética "com os pés no chão", como diria Demo (2000), uma vez que apresentaram na em bases materialistas, ressaltando a hegemonia da matéria (práticas sociais) sobre as ideias. Para o marxismo, as categorias formulam imagens que seriam resultantes "da atividade criadora do sujeito no decorrer da qual este último distingue o geral do singular" (CHEPTULIN, 2004, p.18) e ainda:

\footnotetext{
Esse geral exprime as propriedades $e$ as correlações internas necessárias. É por isso que a imagem ideal que representa o conteúdo dessa ou daquela categoria, sendo a unidade do subjetivo e do objetivo, não coincide imediatamente com os fenômenos, com os quais se encontra na superfície das coisas. Pelo contrário, ela se distingue sensivelmente dos fenômenos e chega mesmo a contradize lós, já que eles não coincidem com a sua essência. $O$ conteúdo das categorias deve coincidir e coincide até certo ponto, não com o fenômeno, mas om sua essência, com esse ou aquele de seus aspectos. (CHEPTULIN, 2004, p. 18, grifo nosso).
} 
Segundo Paulo Netto (2011), as categorias exprimem formas e modos de ser, determinações de existência e, frequentemente, aspectos isolados de uma determinada sociedade. Mediante procedimentos intelectuais (basicamente a abstração), o pesquisador as reproduz teoricamente (e, assim também, pertencem à ordem do pensamento), o que as torna, também, categorias reflexivas. As categorias são históricas e transitórias e o seu estudo deve conjugar a análise diacrônica (da gênese e do desenvolvimento) com a análise sincrônica (sua estrutura e função na organização atual).

No materialismo dialético, as categorias e as leis apresentam um valor essencial, pois "tanto as categorias como as leis refletem as leis universais do ser, as ligações e os aspectos universais da realidade objetiva" (TRIVIÑOS, p. 54, 1987). Para a DHE, as categorias se formam no desenvolvimento histórico do conhecimento e na prática social. Assim, as principais dimensões reveladas nas categorias a priori desta pesquisa são: totalidade/fragmentação; teoria/prática; criticidade/alienação; objetividade/subjetividade; mediações/contradições e autonomia/dependência.

Totalidade/Fragmentação: a totalidade, em uma concepção DHE, é entendida enquanto uma totalidade incompleta, aproximada e imprecisa, formando um todo porque existe uma dinâmica comum. É uma totalidade que mostra rachaduras, por onde sempre pode entrar a antidinamica da mudança.

\footnotetext{
A totalidade não possui apenas a dinâmica circular, que é sempre a mesma e the permitiria recuperar-se eternamente. Ao contrário, a dinâmica é feita de dinâmicas contrárias, feita de convergências e divergências. Sobrepondo-se as convergências, a totalidade continua; do contrário, teremos outra totalidade (DEMO, 2000, p. 109).
}

Teoria/Prática: Teoria e prática são categorias que designam os aspectos espirituais e materiais da atividade objetiva sócio histórica dos homens, muitas vezes, reduz-se o conceito de prática às ações que as pessoas realizam. Mas, quando entendida no seu sentido profundo, não composto simplesmente de atividades frias, mensuráveis e quantificáveis, a prática é uma maneira de viver na história. A prática pode ser entendida como um processo objetivo da produção material, que constitui a base da vida humana, e também como atividade transformadora revolucionária das classes e como outras formas de atividade social prática que conduzem à mudança de mundo. Já a teoria é 
resultado da produção subjetiva, espiritual que existe como noções em desenvolvimento sobre os objetos da atividade humana. Dessa forma teoria necessita da prática e vice-versa, estão interligadas e a todo momento uma renova a outra, trazendo novas perspectivas.

Criticidade/alienação: não podemos imaginar o sujeito totalmente consciente, racional e clarividente, até porque em grande parte ele faz história de modo inconsciente, levado por razões que a razão desconhece, realizando o contrário do que planeja fazer, acertando sem querer, e por vezes, conquistando também o que bem queria que ocorresse (DEMO, 2000). Mesmo assim, a coerência da crítica está na autocrítica, pois não é possível, por lógica e por justiça, criticar sem apresentar-se como criticável. Depois, a crítica se completa na contraproposta, de cunho prático também. "Não é sustentável a mera crítica, destrutiva, virulenta, sem compromisso com alguma construção concreta, que, por sinal, será também criticável” (DEMO, 1995, p.127).

Objetividade/subjetividade: Como exposto anteriormente, consideram-se condições objetivas aquelas dadas externamente ao homem, ou dadas sem sua opção própria e condições subjetivas aquelas dependentes da opção humana, a capacidade de construir a história em parte, no contexto das condições objetivas. Para Demo (2000), não é possível separar a subjetividade da objetividade, pois o componente subjetivo está presente na vivência da prática histórica, no esforço por sua compreensão teórica e na disposição transformadora e criadora. Nesse contexto, a subjetividade se converte em um dado objetivo da realidade histórico- social, e constitui um fator ativo, transformador (e recriador) das situações objetivas. Assim, a subjetividade humana, como fator vivo da transformação histórica, não significa somente o espaço para a negociação de interpretações e sentidos que sustentam a realidade, mas para permitir que os homens transformem a realidade existente criando novas realidades.

Mediação/contradição: a contradição, como dito anteriormente é a categoria essencial para a DHE tendo em vista que para haver diálogo é fundamental que haja a polarização de interesses contrários. A contradição se apresenta na realidade objetiva como uma interação entre aspectos opostos interiores/exteriores, essenciais/não essenciais, etc. 
É fundamental entender que a qualidade política somente é realizável na unidade de contrários. Muitas vezes fazemos de processos participativos a ideia apressada de consensos fáceis e duradouros. Muito pelo contrário, toda comunidade histórica, desde que viva, produtiva, aproxima-se mais da imagem de um caldeirão, onde as coisas fervem. Há choques de interesse, há desgaste no tempo, há luta e labuta. (DEMO, 1995, p. 99).

Autonomia/dependência: A DHE tenta apanhar a dimensão intrinsecamente dinâmica da realidade objetiva e subjetiva visualizando o ser humano limitado (dependente), mas capaz de reagir. Por ser limitado, o sujeito não tem poder de inventar toda e qualquer reação, mas sim as reações limitadas; entretanto, o sujeito sabe e é capaz de fazer dos limites, desafios, bem como perceber que os desafios não desfazem limites.

\subsection{QUADRO TEÓRICO PARA A SUPERAÇÃo DA REALIDADE - RECONSTRUÇÃO DAS CATEGORIAS OPERATÓRIAS}

Para tornar a análise mais objetiva, foram elencadas categorias á posteriori. Os temas abordados e analisados foram: Desenvolvimento Sustentável e includente; Espaço; Território; Turismo e Políticas Públicas; Cidadania, e, Relações de Capital/Trabalho. Essas teorias possibilitaram a visão analítica dos documentos e dados empíricos desta dissertação.

Essa ação tem como intuito construir novos conhecimentos sobre diferentes formas e dimensões do processo de desenvolvimento e seus efeitos nas comunidades.

\subsubsection{DESENVOLVIMENTO SUSTENTÁVEL E INCLUDENTE}

Foi apresentada no capítulo 1 desta dissertação, a evolução da concepção de desenvolvimento que se deu ao longo do tempo e dos contextos sociais. Com essa trajetória, foi possível compreender que o desenvolvimento é um conceito fugidio e em construção, que reconhecidamente tem evoluído, uma vez que tem sido refletido dentro de uma perspectiva holística, sistêmica e complexa, como requer o próprio movimento da realidade social. Entretanto na vida prática das sociedades, ainda na maior parte do planeta, continua preso e submisso á 
racionalidade econômica, já que vem atender à lógica da acumulação capitalista.

Embora as leituras realizadas sobre o conceito de desenvolvimento elaborado por outros autores tenham contribuído, em alguns aspectos, com a concepção de desenvolvimento adotado nesta investigação, este foi abordado a partir da perspectiva de Ignacy Sachs (1993, 2000, 2008) - que embora seja passível de críticas como qualquer outra teoria - se apresenta como uma concepção que busca abranger a totalidade e a complexidade do fenômeno. As contribuições teóricas de Mario Beni $(2003,2006)$ acerca da sustentabilidade no turismo, também foram essenciais para a compreensão de um desenvolvimento sustentável e includente pelo turismo.

As elaborações de Sachs sobre desenvolvimento vêm sendo construídas desde os anos 1960. O autor apresenta uma concepção de desenvolvimento para além das questões objetivas, materiais a que o fenômeno está envolto, incluindo uma perspectiva subjetiva; para ele:

O desenvolvimento pretende habilitar cada ser humano a manifestar potencialidades, talentos e imaginação, na procura da auto realização e da felicidade, mediante empreendimentos individuais e coletivos, numa combinação de trabalho autônomo e heterônomo e de tempo dedicado á atividades não produtivas. A boa sociedade é aquela que maximiza essas oportunidades, enquanto cria simultaneamente um ambiente de convivência (...) e condições para a produção de meios de existência viáveis, suprindo as necessidades materiais básicas da vida comida, abrigo, roupas - numa variedade de formas e cenários família, parentela, redes, comunidades. (SACHS, 2008, p.35, grifo nosso).

$\mathrm{Na}$ concepção de Sachs, para que se atinja uma "boa sociedade", a produção de meios de subsistência depende da combinação de diversos elementos: o acesso a ativos requeridos para a produção de bens e serviços para o autoconsumo, no âmbito da economia doméstica; o acesso a formação profissional, técnicas e ativos necessários para a produção de bens e serviços orientados para o mercado mediante auto emprego; a disponibilidade de trabalho decente, de tempo integral ou parcial, para os membros da família que o desejam; acesso universal aos serviços públicos; acesso à habitação auto construída, alugada ou adquirida mediante esquemas subsidiados de moradia popular, e, a disponibilidade de tempo livre para atividades como o lazer, turismo, artes, etc.

O desenvolvimento sustentável, segundo Sachs, deve obedecer ao duplo 
imperativo ético da solidariedade com as gerações presentes e vindouras, e demanda a explicitação de critérios de sustentabilidade não só em termos ambientais, mas sociais, territoriais e de viabilidade econômica. Para ele, somente as soluções que considerem estes elementos - isto é que promovam o crescimento econômico com impactos positivos em termos sociais, ambientais e territoriais - merecem a denominação de desenvolvimento, posto isso, igualdade, equidade e solidariedade estariam por assim dizer, embutidas no conceito de desenvolvimento.

Sachs denomina dessa forma que os pilares, ou dimensões do desenvolvimento sustentável são: Ambiental - com a dimensão sistemática de sustentação de diferentes vidas no planeta, desempenhando a função de provedores de recursos e como receptores para a disposição de resíduos gerados; o uso dos recursos naturais deve minimizar danos aos sistemas de sustentação da vida: redução dos resíduos tóxicos e da poluição, reciclagem de materiais e energia, conservação, tecnologias limpas e de maior eficiência e regras para uma adequada proteção ambiental; Econômico - compreendendo que a viabilidade é a condição indispensável para que as coisas aconteçam, porém considerando que para tal empreita, há a necessidade de serem atendidos alguns critérios: investimentos públicos e privados e regularização do fluxo destes; compatibilidade entre padrões de produção e consumo; o desenvolvimento econômico intersetorial e equilibrado; razoável nível de autonomia na pesquisa científica e tecnológica; Político - considerando a governança democrática como um valor fundador e instrumento necessário para fazer as coisas acontecerem; no caso do Brasil, é necessária a evolução da democracia representativa para sistemas descentralizados e participativos, construção de espaços públicos comunitários, maior autonomia dos governos locais e descentralização da gestão de recursos; Cultural - respeitando as pluralidades e diversidade de cada cultura, de cada local; Social - fundamental devido ao valor intrínseco e instrumental, por causa da perspectiva de ruptura social que revoa sobre diversos lugares do planeta que tem sérias problemáticas, para tal os critérios a serem atendidos são: melhoria da qualidade de vida da população, equidade na distribuição de renda e de diminuição das diferenças sociais, com participação e organização popular; e, Territorial - que está relacionado á distribuição espacial dos recursos, populações e das atividades, portanto, o equilíbrio entre o rural e o 
urbano; equilíbrio. de migrações; desconcentração das metrópoles; adoção de práticas agrícolas mais inteligentes e não agressivas à saúde e ao ambiente, manejo sustentado das florestas e industrialização descentralizada são condições sine qua non para que se atinja a sustentabilidade territorial. Soma-se à perspectiva de Beni (2006) acerca da sustentabilidade nas dimensões-instrumento que podem ser consideradas como a finalidade dos esforços de desenvolvimento, definidas como: espacial, financeira, mercadológica, política, administrativa, organizacional e jurídica.

O fenômeno turístico fazendo uso do espaço para se produzir e reproduzir, "depende do ordenamento do espaço, da garantia da manutenção dos atrativos, da disponibilidade de serviços e da manutenção da qualidade de paisagem" (BENI, 2006, p.108) e para que se desenvolva de forma sustentável, algumas das premissas propostas por Sachs (1993) são imprescindíveis.

Analisando o turismo, como propiciador da sustentabilidade econômica, foco da análise feita no município de Pirenópolis, esta diz respeito à equidade na distribuição dos benefícios advindos do desenvolvimento das atividades econômicas ligadas ao fenômeno, devendo ser capaz, principalmente, de valorizar as iniciativas locais para construir articulações produtivas de bens e serviços, de forma a privilegiar e ampliar não só as capacidades empresariais locais, mas também aos produtores a se organizarem de plurais formas, por exemplo, com a criação de cooperativas, formas mais solidárias de economia como o consumo de insumos em conjunto, a comercialização de produtos locais, além de propiciar a criação de empregos e geração de renda para a população local.

Beni (2006) define como diretrizes da sustentabilidade econômica no turismo: a geração e distribuição de renda; a expansão da formação de capital; a melhoria do balanço de destino das receitas; e a geração de postos de trabalho.

O autor defende, como Sachs, o enfoque a um desenvolvimento endógeno, em que o crescimento seja baseado na mobilização de recursos internos, colocando as pessoas para trabalharem em atividades com baixo conteúdo de importações, o que permite a aprender a viver com as capacidades locais, com o que o território possui, esta perspectiva de desenvolvimento, visa atender às necessidades e demandas da população local, por meio da participação ativa da comunidade envolvida, buscando o bem estar econômico, social, ambiental e cultural desta. 
Embora seja inegável que o turismo esteja ligado a um crescimento econômico e a uma mudança no cenário sociocultural nas localidades em que ocorre, os efeitos positivos e negativos devem ser avaliados com muita prudência para a proposição de mudanças caso sejam necessárias a fim não de evitar totalmente que os efeitos negativos (já que nem sempre é possível), mas a sim de mitigá-los.

Alguns efeitos em termos econômicos no turismo são passíveis de quantificação (embora esta seja uma tarefa complexa, mas possível), por exemplo, pode se conhecer a sua contribuição no PIB e sua influência na expansão do mercado de trabalho, dentre outros, estes efeitos "positivos", são comumente utilizados como a grande justificativa, tanto do poder público como da iniciativa privada, para fomentar o turismo, denotando a visão economicista do fenômeno. No entanto, em se tratando de efeitos socioculturais, a mensuração é muito complexa, uma vez que os resultados são muito mais de ordem qualitativa, subjetiva.

Beni (2006) defende como Sachs (2008), a criação de Arranjos Produtivos Locais (APL's) para um desenvolvimento sustentável e sustentado; no caso do turismo, para ele, o planejamento e criação de APL's do setor primário, assegurariam a sobrevivência e a manutenção da atividade produtiva da população autóctone, fazendo com que o turismo venha a oferecer um cenário mais ampliado e renovado da produção, quer seja em sua atividade primária básica, quer seja nas atividades prestadoras de serviço, ou ainda, na complementariedade de ofícios e habilidades artesanais.

Relevante é destacar que a depender do posicionamento político-ideológico daqueles que elaboram e participam dos Arranjos Produtivos Locais, estes podem se tornar apenas uma estratégia para a "competitividade" que atende à logica global do capital.

Embora a perspectiva endógena, possa ser interessante para o desenvolvimento de um turismo sustentável, ela não deve cair na ingenuidade do "localismo", portanto a visão multiescalar, o movimento global/local; microeconomia/macroeconomia; deve ser considerada, sobretudo em um mundo cada vez mais globalizado. Além disso, as contradições que são próprias da sociedade: as contradições entre as classes sociais, os oligopólios econômicos, as hegemonias politicas, devem ser também consideradas, sendo assim, o desafio é 
assumir uma visão dialética da realidade e da sociedade, tal qual elas o são.

Embora seja reconhecível a evolução ao longo dos tempos, do conceito de desenvolvimento, que comporta tanto a sua complexificação quanto as novas e diferentes problemáticas, Sachs (2008, p.37) admite que, "carecemos de um paradigma convincente capaz de lidar com dois problemas (...), desemprego maciço/subemprego e desigualdade crescente".

O desenvolvimento includente para Sachs (2008) deve ser fundamentado em um trabalho decente para todos.

A sustentabilidade social para Sachs (1993) tem como objetivo:

(...) a construção de uma civilização do "ser", na qual haja maior equidade na distribuição do "ter" e da renda, para a melhoria dos direitos e das condições de vida da população, de forma também a abranger as necessidades materiais e não materiais das pessoas (SACHS, 1993, p.21).

A distribuição desequilibrada da riqueza; a fragmentação do mundo; a competitividade espúria e autodestrutiva, com base na depreciação dos trabalhadores e dos recursos naturais; as economias caracterizadas por um alto grau de desperdício, sobretudo, a forma de desperdício que destrói vidas humanas via déficit de oportunidades de trabalho decente, são aspectos relevantes da exclusão social que cada vez mais assola o mundo e seus viventes, em todos os sentidos.

$\mathrm{Na}$ visão de Sachs, a inclusão justa, seria o aspecto mais essencial do paradigma do desenvolvimento; ele define desenvolvimento includente em oposição ao padrão "excludente" (do mercado de consumo) e "concentrador" (de renda e riqueza); outros aspectos do crescimento "excludente" seriam: a) os mercados de trabalho fortemente segmentados, que mantém a maioria dos trabalhadores confinados em atividades informais, ou condenados a obter a sua "subsistência" precariamente pela agricultura familiar de pequena escala e sem quase nenhum acesso à proteção social; b) a fraca participação na vida política, ou completa exclusão dela, devido a maior parcela da população ser pouco instruída (graças à precária qualidade na educação ou mesmo inexistência desta), suborganizada e estar absorvida na luta cotidiana pela "sobrevivência", em que as mulheres, são as mais atingidas.

Para Sachs (2008), o desenvolvimento includente exige acima de tudo a 
garantia do exercício dos direitos civis, políticos e cívicos, sendo a democracia direta $^{42}$ um valor fundamental, que garante também a transparência e a responsabilização, elementos essenciais para o funcionamento do processo de desenvolvimento. $O$ acesso de todos os cidadãos em igualdade a programas de assistência, contemplando as diferentes desigualdades naturais ou físicas (idosos, deficientes, etc.); a igualdade na oportunidade de acesso a serviços públicos: educação, saúde, moradia, são vitais para o desenvolvimento incluente.

A educação é um elemento essencial, com valor imprescindível, pois contribui para o "despertar cultural", a conscientização, compreensão dos direitos humanos, a autonomia, autoconfiança e autoestima do indivíduo e da sociedade, mas possui ao mesmo tempo um valor instrumental em relação á empregabilidade, entretanto, ela não é a garantia de acesso a um trabalho decente, pois junto a isso deve vir um pacote de políticas públicas com vistas a um desenvolvimento integral.

O acesso á serviços de saúde, são importantes também, no entanto eles devem fazer parte de um objetivo mais amplo, com vistas a melhorar a saúde da população, portanto, uma alimentação adequada (segurança alimentar); acesso á água limpa, melhoria das condições de moradia e trabalho, educação com qualidade e medidas preventivas como vacinação, vigilância sanitária, são aspectos importantes para que ocorra de fato a melhoria da saúde dapopulação.

Um enorme desafio para que se efetive um desenvolvimento includente, é a provisão de moradia decente para todos; esta que é uma necessidade básica para os seres humanos, portanto, a importância de políticas públicas de moradias populares; esquemas baseados na autoconstrução assistida, dentre outros, são caminhos para vencer esse desafio.

Embora esses serviços públicos - programas de assistência, saúde, educação e moradia - sejam relevantes, eles necessitam de financiamento público, por meio da redistribuição de uma parcela do PIB. As políticas compensatórias (que redistribuem a renda mediante sistema fiscal) são tão necessárias quanto às políticas de emprego (que mudam a distribuição da

\footnotetext{
${ }^{42} \mathrm{O}$ autor reconhece que existe uma grande distância entre a democracia representativa e a democracia direta, e esta última para ele, é a que cria melhore condições para o debate dos assuntos de interesse público.
} 
renda primária), porém cabe ressaltar que:

(...) a política de geração de emprego deve ser preferida em detrimento das políticas compensatórias, se não por outra razão, porque as segundas nunca proporcionam a dignidade que provém do emprego (SACHS, 2008, p.41, grifos nossos).

Por isso, Sachs (2008), defende o crescimento puxado pelo emprego ${ }^{43}$, a geração de oportunidades do que ele denomina trabalho decente e/ou auto emprego, ou seja, razoável em termos de remuneração dentro das condições de seu país - e no Brasil pode se dizer até das regiões e/ou localidades, dado as dimensões continentais e aspectos culturais -, de condições de trabalho e de relações de trabalho. Para ele, a questão dos empregos importa muito para a formulação de estratégias de desenvolvimento includente; e sua maximização deve ser objeto de estudos e de negociações entre os poderes públicos, empresários e trabalhadores, com vistas à construção do que ele convencionou chamar de sinergias positivas.

No turismo, Beni (2006), traz uma perspectiva bastante parecida com a de Sachs. A contribuição do turismo, de acordo com o autor, para a sustentabilidade social pode ser assumida com a implementação de ações que promovam a satisfação contínua das necessidades básicas humanas, como: alimento, água, saúde, segurança, liberdade, emprego e recreação, fundamentada na melhoria da qualidade de vida das pessoas, principalmente das mais pobres. As principais diretrizes da sustentabilidade social, para Beni (2006), são: influência na dinâmica da população; dinâmica do mercado de trabalho (compromisso com o trabalho e a ocupação nas atividades relacionadas ao turismo, resultando em um modelo includente e estável); capacitação para o turismo; educação; saúde; ordenamento territorial; e habitação.

Dentre essas diretrizes elencadas por Beni (2006), a contribuição do turismo com a sustentabilidade social pode se dar também á medida que, ao mesmo tempo em que se melhora a oferta de equipamentos e produtos

\footnotetext{
${ }^{43} \mathrm{O}$ crescimento puxado pelo emprego para Sachs ocorre somente mediante algumas condições: a) capacidade local de planejamento, entendido como capacidade de identificação de gargalos e de recursos ociosos capazes de superá-los; b) estímulo á capacidade de mobilizar recursos iniciativas locais c) reabilitação do sistema financeiro nacional, para dotá-lo de um mínimo de capacidade de atender às necessidades das empresas e do financiamento de obras públicas, sem excluir o recursos á quase moeda e à promoção do escambo; d) uma reforma fiscal que criasse um imposto de Valor Adicionado progressivo sobre o consumo: haveria isenção para os bens essenciais, mas ele teria forte incidência sobre artigos de luxo, os salários baixos seriam subsidiados com este imposto.
} 
turísticos, e mesmo os espaços de lazer, ampliam-se as oportunidades de expressão de cidadania com a melhoria da qualidade de vida da comunidade autóctone.

Logo, o esporte, o lazer, a cultura e o turismo devem ser tratados como direitos fundamentais (inclusive garantidos pela constituição brasileira), entendendo que o prazer, a satisfação, a felicidade, devem ser colocados no mesmo patamar das outras necessidades essenciais como a educação, moradia, saúde.

O desenvolvimento de um turismo que contemple a sustentabilidade se traduz em conseguir simultaneamente que ele seja sustentado, do ponto de vista econômico e político-institucional, portanto viável e realizado com base ética; includente do ponto de vista social; e sustentável do ponto de vista ambiental e cultural; e embora seja um grande desafio, esse vem a ser uma utopia ${ }^{44}$ (encarada como uma visão antecipada da sociedade; como uma possibilidade) necessária.

\subsubsection{ESPAÇO; TERRITÓRIO}

Falar de turismo enquanto fenômeno e prática social requer a compreensão inevitável de três elementos: o sujeito, o tempo e o espaço, visto que o mesmo não ocorre sem esses. Fundamental se faz o conhecimento das categorias espaço e território, as quais a Geografia utiliza para a compreensão de uma realidade.

Espaço e território, não são categorias idênticas para Raffestin (1993); o espaço antecede ao território, e, este último é fruto de uma ação programada de sujeitos que se apropriam concreta e/ou simbolicamente do espaço.

O território é formado em sua multidimensionalidade pelos sujeitos que o redefinem cotidianamente, em um "campo de forças", de relações de poder das mais variadas intensidades e ritmos. O território é também resultado das diversas territorializações que operam sobre ele; das forças que cruzam e se entrecruzam e

\footnotetext{
${ }^{44}$ Utopia aqui é entendida nos termos que Harvey (2000), propõe: "um utopismo espaço-temporalum utopismo dialético - que tenha raízes fincadas em nossas possibilidades presentes ao mesmo tempo em que aponta trajetórias diferentes para os desenvolvimentos geográficos desiguais humanos". (HARVEY, 2000, p.258).
} 
que definem os seus contornos.

Território é um conceito que pode ser compreendido e tratado de acordo com seus diferentes aspectos que lhe são intrínsecos, logo, não existe uma única concepção de território aplicável a todas as diversas esferas das Ciências Sociais, neste sentido, Haesbaert (2006) mostra que existem diferentes perspectivas:

(...) enquanto o Geógrafo tende a enfatizar a materialidade do território, (...), a Ciência Política enfatiza sua construção a partir de relações de poder (...); a Economia, que prefere a noção de espaço à de território, percebe-o muitas vezes como um fator locacional ou como uma das bases da produção (...); a Antropologia destaca a sua dimensão simbólica (...); a Sociologia o enfoca (...) nas relações sociais, em sentido amplo, e a Psicologia, finalmente, incorpora-o no debate sobre a construção da (...) identidade pessoal (...). (HAESBAERT, 2006, p. 37).

No entanto em se tratando do fenômeno do turismo, o território pode ser tratado a partir de todas essas diferentes perspectivas e dimensões, devido ao seu caráter interdisciplinar, sistêmico e complexo, por isso, torna-se ainda mais difícil a legitimação de apenas uma concepção. A depender do objeto de investigação, o enfoque dar-se-á em determinadas vertentes, ora política-jurídica, ora natural, econômica, etc.

Por questões metodológicas, nesta dissertação, a compreensão sobre território está focada em sua dimensão material-concreta (política, econômica), mas sem negar a dimensão subjetiva e simbólica (cultural).

Claude Raffestin (1993) entende que ao se apropriar de um espaço, concreta ou abstratamente, o sujeito, territorializa o espaço. Neste sentido, entende o território como sendo:

(...) um espaço onde se projetou um trabalho, seja energia e informação, e que, por consequência, revela relações marcadas pelo poder. (...) o território se apoia no espaço, mas não é o espaço. É uma produção a partir do espaço. Ora, a produção, por causa de todas as relações que envolve, se inscreve num campo de poder (...) (RAFFESTIN, 1993, p.144).

Para RAFFESTIN (1993), a construção do território revela relações marcadas pelo poder, e o poder está intrínseco em todas as relações sociais, portanto, o turismo não escapa a esta lógica.

É através das práticas sociais e do desenvolvimento das técnicas, ou seja, 
da ação antrópica, que o espaço natural se transforma e é dominado. E ao ser dominado - sobretudo pelas relações de poder, político e/ou econômico - com o objetivo de que sirva ás necessidades de um grupo, este se apropria do espaço, logo, o território é formado pelas relações de domínio e apropriação, no, com e pelo do espaço.

Santos (1996), reconhece que encontrar uma definição única tanto para espaço, quanto para território é uma tarefa árdua, uma vez que cada categoria tem diversas acepções e recebe diferentes elementos, de forma que toda e qualquer definição não é uma definição imutável, portanto, os conceitos têm diferentes significados, que vão sendo historicamente construídos e definidos.

No entanto, Santos (1985), compreende que a formação do território é algo externo ao território; a periodização da história é que define como este será organizado; o que será o território e como serão as suas configurações econômicas, políticas e sociais.

O autor evidencia o espaço como variável a partir de seus elementos quantitativos e qualitativos, partindo de uma análise histórica:

O que nos interessa é o fato de que cada momento histórico, cada elemento muda seu papel e a sua posição no sistema temporal e no sistema espacial e, a cada momento, o valor de cada qual deve ser tomado da sua relação com os demais elementos e com o todo. (SANTOS, 1985, p. 09. grifo nosso).

Espaço e território para Santos (1996), não podem ser confundidos, o autor nomeia o território como configuração territorial, como uma fração do espaço:

A configuração territorial é dada pelo conjunto formado pelos sistemas naturais existentes em um dado país ou numa dada área e pelos acréscimos que os homens superpuseram a esses sistemas naturais. A configuração territorial não é o espaço, já que sua realidade vem de sua materialidade, enquanto o espaço reúne a materialidade e a vida que a anima. (SANTOS, 1996, p.51).

Espaço é concebido como totalidade. O território está contido no espaço, e o espaço, no território em um movimento dialético.

Para ele, território corresponde aos complexos naturais e às intervenções, construções feitas pelo homem: plantações, indústrias, aeroportos, estradas, casas, cidades, etc. O território é construído historicamente, cada vez mais, como negação da natureza natural. Para SANTOS (2002), o território configura-se 
pelas técnicas, pelos meios de produção, pelos objetos e coisas; é entendido enquanto território usado.

Segundo Santos (2006), toda e qualquer forma de repartição do espaço é dependente da maneira como os instrumentos de trabalho e os fatores de produção se distribuem, por conseguinte, economia e política, são fatores importantes na compreensão do espaço; da construção de territórios; das mudanças que ocorrem neste.

No atual contexto da globalização e da acumulação capitalista, o espaço torna se um campo de forças multicomplexo, em virtude da individualização e "especialização" minuciosa dos elementos do espaço: homens, empresas, instituições, meio ambiente construído; ao mesmo tempo em que se aprofunda a relação de cada qual com o sistema mundo" Santos (2002, p.314), ou seja, experimenta-se uma relação dialética entre o mundo e os lugares, o local e o global; embora os lugares passem a conter características mundiais, há ao mesmo tempo um movimento de resistência que resguarda suas características específicas, que os diferem dos demais lugares.

O espaço como produção no capitalismo “(...) expande se territorial e socialmente incorporando as atividades do homem, redefinindo se sob a lógica do processo de valorização do capital" (Carlos, 2011, p. 64), este processo de valorização, em que o espaço é encarado enquanto "espaço-mercadoria", provoca múltiplas contradições e conflitos na sociedade (urbana e rural, uma vez que o fenômeno da globalização penetra em todos os lugares do planeta), esses conflitos, por sua vez:

explicitam as estratégias que criam novos setores da atividade como extensão das atividades produtivas, pois a reprodução do ciclo do capital exige, em cada momento histórico, determinadas condições especiais para sua realização.(CARLOS, 2011, p. 64, grifos nossos).

Neste sentido, o turismo, como considerado pelo sistema capitalista de forma reducionista enquanto mercadoria, produz "simulacros" espaciais, como as denominadas "cidades-patrimônio", que se tornam espaços a serem consumidos tanto pelos sujeitos/agentes que investem seus capitais, quanto por aqueles turistas - que usufruem da natureza e dos bens culturais e materiais da cidade, na relação capitalista de oferta-demanda

O poder sobre o espaço que é exercido pela posse do capital, é 
manifestado no espaço físico apropriado, "sob a forma de uma certa relação entre a estrutura espacial da distribuição dos agentes e a estrutura espacial da distribuição dos bens ou dos serviços, privados ou públicos" (BOURDIEU, 1999, p.160), mas essa apropriação se dá também de forma simbólica.

Transpondo essa reflexão para o turismo, pode-se depreender da realidade das "cidades-patrimônio", que há uma migração dos moradores das áreas centrais, que passam a ser apropriadas quase que totalmente pelo poder do capital. As pessoas que ali habitam vendem seus imóveis ou os alugam e passam a viver em bairros mais afastados, propiciando uma nova lógica do espaço social.

A estrutura do espaço social se revela enquanto oposições espaciais, em que o espaço habitado (ou apropriado) funciona como uma espécie de simbolização espontânea do espaço social, de modo que encontrando se o espaço social inscrito tanto nas estruturas espaciais, quanto nas estruturas mentais, 0 mesmo vem a se tornar um dos lugares onde o poder se afirma e se exerce, de uma forma muito sutil. As lutas que ocorrem pela apropriação desses espaços sociais objetivados, se dão devido aos ganhos que os mesmos proporcionam, ganhos estes que Bordieu (1999) denomina de ganhos de localização, ou seja, quando a localização é interessante, por estarem próximas a equipamentos de saúde, educacionais, entre outros; ganhos de posição, de "status" na sociedade, ou ganhos de ocupação (ou acumulação), em que o "ganho" se dá pela posse de um vasto espaço físico, podendo propiciar um distanciamento de tudo que é indesejável, a exemplo dos condomínios horizontais de luxo que são construídos nas áreas verdes periféricas das cidades, criando "novas cidades" dentro da cidades, inclusive nas cidades ditas turísticas que participam também dessa lógica, a exemplo dos condomínios de segunda residência (casa de campo ou de praia); os resorts construídos em oásis naturais, etc.

Lefebvre (2008), aponta uma reflexão relevante acerca do espaço, que elucida a questão da problemática dos espaços sociais ou espaços vividos que perpassam pela apropriação do capital.

O autor entende o espaço não só enquanto um instrumento político de poder intencionalmente manipulado, (representado por um grupo ou pessoas que tanto podem representar uma sociedade global como atender a seus próprios interesses), mas como um lugar para a reprodução das relações de produção. 
Logo, para ele os lugares de lazeres, (que podem ser denominados também como lugares do turismo), embora "aparentem" ser separados da produção, visto que não produzem algo tangível, como uma mercadoria, estão estritamente ligados ao trabalho produtivo, pois são lugares que incluem a reprodução da força de trabalho.

\subsubsection{TURISMO E POLÍTICAS PÚBLICAS}

O Turismo é um fenômeno contemporâneo, que tem seu início marcado concomitante ao início e desenvolvimento do capitalismo, todavia sua expansão como atividade de lazer ocorre a partir de 1960, momento este marcado por grandes fluxos de milhares de pessoas pelo mundo, tornando-se então uma atividade econômica de expressão.

Avanços no pensamento sobre o fenômeno ocorreram, porém incipientes no campo epistemológico, o que dificulta ainda mais uma concepção liberta dessa ótica restritamente econômica. A própria Organização Mundial do Turismo (OMT) que a priori, deveria ter uma concepção que abarcasse a complexidade do turismo, contrariamente o concebe de forma bastante simplificada, enfatizando a aparência do fenômeno, ou seja, o movimento dos fluxos turísticos e seus impactos nas economias mundiais e não a sua essência.

Para Moesch (2004):

O Turismo é uma combinação complexa de inter-relacionamentos entre produção e serviços. Em razão de não ser uma atividade produtiva agrícola ou industrial, normalmente é classificada no setor terciário ou de serviços. É muito mais que uma indústria de serviços, pois o fenômeno turístico é a composição de uma prática social com base cultural, com herança histórica, meio-ambiente diverso, cartografia natural, relações sociais de hospitalidade, troca de informações interculturais. O somatório desta dinâmica sociocultural parte de um fenômeno recheado de objetividade/subjetividade (...) (MOESCH, 2004, p.15).

A dificuldade em se compreender seu caráter multi setorial, pode isolar as atividades a ele associadas pertencentes a outros setores produtivos e sociais, ocasionando uma descrença ao seu desenvolvimento.

Concebido como um sistema aberto, de conteúdo interdisciplinar, o turismo é um processo humano que ultrapassa o entendimento enquanto função de um 
sistema econômico, no entanto o fenômeno não dispensa o planejamento para se desenvolver.

Dessa forma sem a presença ou a iniciativa do Estado regulando politicamente a economia, até por volta do início do século $X X$, não havia a política pública, as ações econômicas dependiam exclusivamente de um mercado que se auto regulava. Para Meksenas (2002), "O conceito de políticas públicas aparece vinculado ao desenvolvimento do Estado capitalista e esse, às relações de classe." (MEKSENAS, 2002, p.77).

Esse momento é que marca o surgimento das políticas públicas. Embora existam diferentes conceitos; por políticas públicas pode se entender, segundo Heidemann (2010) como:

(...) o conhecimento dos fenômenos ligados á regulamentação e ao controle da vida humana em sociedade, como também à organização, ao ordenamento e à administração das jurisdições político-administrativas (nações, estados, municípios ou distritos).(HEIDEMANN, 2010, p.29).

Segundo o autor, a definição de política pública deve ainda incluir dois elementos-chave: ação e intenção; não haverá de forma alguma política se não houver ações que materializem uma intenção eventualmente enunciada. Sua formalização propicia a comunicação e entendimento entre o governo e cidadãos, servindo como base de referência.

Vale ressaltar que a perspectiva de política pública vai para além da perspectiva de políticas governamentais (entendidas estas como geridas pela estrutura administrativa do Estado), na medida em que o governo não é a única instituição a servir a comunidade, a promover políticas públicas.

Para Gastal e Moesch (2007), políticas públicas seriam:

(...) as intervenções realizadas pelo Poder Público, instituições civis, entidades privadas e grupos comunitários, com o objetivo de atender à população nas suas necessidades materiais e simbólicas, garantindoIhes acesso às mesmas, para que seja alcançada maior e melhor qualidade de vida não só para os grupos hegemônicos, mas também e em especial - para os excluídos por razões econômicas, sociais e culturais, etárias ou de gênero, dentro do respeito do direito à diferença.(...) políticas públicas se caracterizariam pela democratização do usufruto dos bens - democratização de acesso - e pela organização da sociedade para a determinação e distribuição desses bens democratização da gestão. (GASTAL; MOESCH, 2007, p.40-41, grifo nosso).

Em linhas gerais, as políticas públicas para o turismo no Brasil, são 
formadas por um conjunto de objetivos, diretrizes, regulamentações e estratégias que são estabelecidas e/ou deliberadas, sobretudo no campo do poder público, que tem como objetivo o desenvolvimento do turismo de uma localidade.

Diversas concepções sobre planejamento e políticas públicas do turismo tem sido construídas ao longo do tempo. Para Beni (2003), política pública de turismo pode ser entendida como:

[...] o conjunto de fatores condicionantes e de diretrizes básicas que expressam os caminhos para atingir os objetivos globais para o Turismo do país; determinam as prioridades da ação executiva, supletiva ou assistencial do Estado; facilitam o planejamento das empresas do setor quanto aos empreendimentos e às atividades mais suscetíveis de receber apoio estatal. (BENI, 2003, p.101).

Para Cruz (2001), política pública de turismo se configura como:

[...] um conjunto de intenções, diretrizes e estratégias estabelecidas e/ou deliberadas, no âmbito do poder público, em virtude do objetivo geral de alcançar e/ou dar continuidade ao pleno desenvolvimento da atividade turística num dado território. (CRUZ, 2001, p. 40).

Segundo Molina e Rodríguez (2001), o turismo foi concebido pela superestrutura latino-americana como um fator de desenvolvimento, em virtude de seus "possíveis efeitos econômicos". Além disso, também Ihe foi atribuída uma relevante tarefa no esforço de integração nacional.

O sucesso da inserção do modelo de indústria turística ${ }^{45}$ nas economias latino americanas pode se explicar pelo caráter das relações de dependência estabelecidas entre o centro e a periferia e pela necessidade de reverter 0 empobrecimento constante dos países latino-americanos.

O turismo, ao converter-se num setor exportador, adequou-se às necessidades de consumo de países desenvolvidos, especialmente dos Estados Unidos da América. De acordo com os autores, as políticas de desenvolvimento turístico latino-americanas também são orientadas conforme os

\footnotetext{
${ }^{45}$ A concepção de turismo enquanto indústria não reconhece o processo sistêmico e integrador dos setores sociais, culturais e ambientais abarcados por ele, mas sim a ideia de negócio. A indústria do turismo se alicerça no desenvolvimento econômico, no lucro, nas técnicas e nas tecnologias para a exploração dos lugares, adequando-se às necessidades de consumo dos países desenvolvidos, especialmente os EUA. Infelizmente, em função do momento político e econômico em que se encontrava a América Latina ao longo do século XX, a concepção de turismo assimilada pelos países da região foi, justamente, essa ideia de turismo enquanto indústria. MOLINA; RODRíGUEZ, 2001).
} 
interesses e as necessidades dos países centrais.

\begin{abstract}
Na América Latina não existe, em nível nacional, um país que se encontre estruturalmente comprometido em um esforço por desenvolver o turismo, no sentido e significado rigoroso que se tem dado ao conceito de desenvolvimento. $O$ feito de fomentar modelos urbanos e arquitetônicos dos países do centro em seus espaços turísticos, subordinar suas próprias capacidades a dos interesses dos grandes consórcios turísticos transnacionais, de contaminar de modo quase irreversível ecossistemas de apoio ao turismo são indícios determinantes desse processo.(MOLINA, 2000, p.52).
\end{abstract}

Portanto, para Molina (2000), na América Latina, o turismo constitui apenas uma atividade complementar da economia dos países desenvolvidos, com a qual se reforça a relação dominação-dependência, tendo em vista que a política turística vigente nos países da região tem buscado exclusivamente facilitar à população dos países industrializados o desfruto de seu tempo livre.

[...] o turismo (em nossas comunidades) é planejado sempre baseado na obtenção de divisas, na geração de empregos e na redistribuição dos investimentos internos nunca como resposta à necessidade de distribuição de um povo. (FUENTES, 1979 apud MOLINA; RODRÍGUEZ, 2001, p.55).

Por ser o Turismo, um fenômeno complexo e dinâmico, é perpassado e interligado por uma diversidade de políticas públicas que interagem com o mesmo, como exemplo as políticas de infraestrutura; de comunicações; ambientais; culturais; de transporte; trabalhistas, dentre outras, que se orientam a objetivos gerais diferentes e que são aplicadas em diversas realidades do cotidiano da sociedade.

No entanto essas mesmas políticas podem propiciar direta ou indiretamente impactos positivos ou negativos ao turismo.

De acordo com Villar (2009), a diversidade de políticas que auxiliam o turismo, revelam também a vulnerabilidade que o turismo tem frente a determinadas ações humanas, entre as quais se destacam a elaboração e a implementação de políticas públicas.

Segundo a OMT (1999), as políticas de turismo devem ser desenvolvidas pautadas no respeito pelo patrimônio artístico e natural das comunidades, permitindo a sobrevivência das tradições e o desenvolvimento sustentável, evitando a padronização e o empobrecimento do local. Sendo assim, cabe à política de turismo o estabelecimento de metas e diretrizes que orientem o 
desenvolvimento socioespacial da atividade, tanto no que tange à esfera pública quanto no que se refere à esfera privada, pois, na ausência da orientação política, o turismo se desenvolveria ao sabor de iniciativas ou interesses particulares, embora pode-se depreender da realidade que muitas políticas públicas de turismo de diferentes escalas (federal, estadual e municipal) se rendem ao interesse do capital em detrimento do cidadão.

Portanto, a política de turismo deve funcionar tanto no estímulo quanto no controle direto do desenvolvimento do turismo, bem como deve preocupar-se com a proteção dos interesses da sociedade como um todo e não exclusivamente a serviço do capital.

Para Gastal e Moesch (2007), as políticas públicas do turismo acima de tudo devem ter primeiramente "clareza sobre a concepção de Turismo que defende, sobre qual a visão de desenvolvimento buscar e quais são os seus compromissos" (GASTAL; MOESCH, 2007, p.42).

Moesch (2012) faz referência às mudanças sociais ocasionadas pelas políticas públicas do turismo:

\begin{abstract}
A dimensão social das políticas públicas de turismo, assim como as políticas sociais, são incentivadoras de cidadania por serem redistributivas em termos de renda e poder; e possibilitadora do manejo de bens simbólicos. Podem ser equalizadoras de oportunidades no sentido de instrumentar desiguais para que tenham chances históricas emancipatórias, não no sentido de doar a emancipação ao outro, mas de que possam se emancipar (MOESCH, 2012, p. 203).
\end{abstract}

Segundo Gastal e Moesch (2007), a busca pela consolidação da democratização das políticas públicas de Turismo devem: a) ter normatizações jurídicas; b) realizar intervenções diretas como: linhas de financiamento, implantação de infra estrutura, gerenciamento de informações, treinamento e qualificação de recursos humanos, com a lógica da proteção a grupos e comunidades frágeis, por razões econômicas e/ou culturais; c) consolidar diretrizes políticas que não incentivem apenas 0 turismo nos seus desdobramentos econômicos, mas também nas suas implicações socioculturais centradas no turista.

As políticas públicas do turismo devem promover a elaboração do planejamento e a gestão de forma participativa e compartilhada, devem ainda articular questões estratégicas enredadas junto aos empresários do turismo e 
à comunidade local, aprofundando a participação democrática.

Relevante é entender e reconhecer que todo planejamento, toda política pública não é neutra, há sempre uma ideologia por trás que a sustenta. Portanto, conflitos de interesses são inerentes a ela, e embora seja difícil administrá-los, salutar é que eles existam, pois é graças a esses processos que as novas formas de desenvolvimento podem ser construídas; o grande desafio é que elas atendam aos anseios da coletividade como um todo.

\subsubsection{CIDADANIA}

A ideia de cidadania como o resultado da ação na esfera pública emerge na Grécia Clássica, momento em que os gregos atenienses se agregavam em praças públicas, denominadas de ágoras com o objetivo de discutir as questões e o futuro da pólis ${ }^{46}$. A ágora, portanto, era o espaço em que seriam tomadas todas as decisões políticas, um espaço em que imperava a democracia, em que "todos" seriam iguais. "Todos" em tese, uma vez que somente aqueles que eram considerados cidadãos tinham o direito de participar.

Pode-se observar pela história, que a questão da cidadania esteve sempre relacionada à conquista de direitos, e todo este movimento histórico proporcionou, no aspecto legal, uma evolução destes. Nesse sentido, de acordo com Meksenas (2002), pensadores contemporâneos como Thomas H. MARSHAL e Norberto BOBBIO revelam que na evolução dos direitos, encontra se três grupos distintos:

a) Direitos civis: correspondentes ao conjunto das liberdades individuais estabelecidas por meio da igualdade jurídica; Compreendese 0 direito de liberdade, como o direito que tende a limitar 0 poder do Estado e a reservar para o indivíduo, ou para os grupos particulares uma esfera de liberdade em relação ao Estado;

b) Direitos políticos: referentes ao exercício do poder, e são estabelecidos por mecanismos de participação social e política; Os direitos políticos, segundo BOBBIO, são aqueles os quais tiveram como

\footnotetext{
${ }^{46}$ Pólis é uma palavra grega, que significa cidade.
} 
consequência a participação cada vez mais ampla, generalizada e frequente dos membros de uma comunidade no poder político;

c) Direitos sociais: que se apresentam como o conjunto das garantias mínimas do bem-estar econômico, de acordo com os padrões culturais aceitos por uma sociedade. São regidos pelo signo da igualdade e visam ao bem estar social.

A Declaração dos Direitos do Homem e do Cidadão elaborada pelos franceses em 1789 no contexto da Revolução Francesa é um marco na história, e ganhou relevância, pois os direitos civis foram garantidos aos homens por "lei". Essa Declaração teve um caráter universalista, não se restringindo apenas a cidadãos franceses.

É reconhecível a relevância das diversas inovações que ocorreram advindas dessas revoluções, no entanto, de acordo com Marx e Engels apud Meksenas (1976), tais inovações contiveram as contradições da sociedade de classes, visto que:

(...) ao mesmo tempo que eram produto de uma particularidade - a práxis burguesa -, a sua expressão ideológica as apresentou como um fato universal. A tensão particularidade-universalidade da política se constituiu como uma aparência social necessária. Ou seja, a burguesia realizou seus interesses de classe na medida em que anunciou como propósitos da humanidade. Com isso, criou as condições da distensão dos espaços jurídico-formais no momento em que as classes trabalhadoras começavam a impor suas bandeiras de luta. Os direitos, como aparência social necessária, produziram uma fenda entre a promessa burguesa e o exercício da política pelos trabalhadores. (MEKSENAS, 2002, p.33-34).

Marx faz uma crítica em relação a Declaração dos Direitos do Homem e do Cidadão, uma das ordenações jurídico-formais, que se estabelecem enquanto "inovações" no processo de construção da cidadania.

Para ele, há uma distinção entre os direitos civis ou do cidadão e os direitos humanos enquanto direitos naturais do homem abstrato. Como o último é a personificação histórica da práxis burguesa, o autor conclui que os direitos humanos ou naturais são, na verdade, burgueses. Os ideais decorrentes da Revolução Francesa (a liberdade, a propriedade, a igualdade e a segurança) para Marx são direitos que se negam mutuamente. 
Meksenas (2002) entende a cidadania como possibilidade de exercício do poder na sociedade que é por sua vez dividida pelas classes sociais, portanto, é sempre uma cidadania de classe. Cidadania é para ele, uma categoria crítica de análise, acima de tudo, das contradições históricas, que envolvem a participação política das classes trabalhadoras nas suas lutas por direitos. Para o autor cidadania é concebida enquanto um conceito-rede, que articula outros: direitos, participação, políticas públicas, sociedade civil e Estado. Conceito-rede, pois "o seu significado emerge ao permitir a relação e a justaposição de vários outros conceitos das ciências sociais". (MEKSENAS, 2002, p.17).

O exercício da cidadania para Meksenas (2002), só é possível, no momento em que a participação política por direitos é capaz de se sobrepor àquelas políticas públicas que realizam os interesses do mercado, e essa participação se dá pelas lutas sociais cotidianas.

Pedro Demo (1995), tem uma concepção de cidadania centrada na capacidade humana, que sobretudo é impulsionada pela educação, esta que por sua vez, pode propiciar a emancipação social, para ele, cidadania é:

(...) competência humana de fazer-se sujeito, para fazer história própria e coletivamente organizada. Para 0 processo de formação dessa competência alguns componentes são cruciais, como educação, organização política, identidade cultural, informação e comunicação, destacando-se acima de tudo o processo emancipatório. Este funda-se, de partida, na capacidade crítica para, com base nesta, intervir na realidade de modo alternativo. O desafio maior da cidadania é a eliminação da pobreza política. (...) Cidadania é, assim, a raíz dos direitos humanos, pois estes somente medram onde a sociedade se faz sujeito histórico capaz de discernir e efetivar seu projeto de desenvolvimento. (DEMO, 1995b, p.1-3).

A questão da cidadania do povo brasileiro, é marcada pela exclusão de parcela da comunidade (mulheres, escravos, negros, crianças e adolescentes, portadores de deficiência) de seus direitos fundamentais.

Embora atualmente a afirmação dos direitos civis, políticos e sociais esteja caracterizada na Constituição Federal de 1988, estes se consolidam de forma fragmentada, em que são dissociados uns dos outros; como realidade autônoma. Ainda hoje o poder político patrimonial se afirma continuamente, produzindo a cultura do privado que se apropria do público. A postura da população frente ao poder público se reveste de atitudes permeadas pela 
submissão, de quem se vê recebendo um favor, portanto, "a sociabilidade que se estabelece nesse contexto não tem por base a racionalidade do contrato social, que permeia a noção de direitos, como no modelo clássico". (MEKSENAS, 2001, p.60). Ao contrário disto o que prevalece são as mediações entre $o$ atendido e 0 atendente do poder público, onde a prestação de favores, pagamento de recompensas e o uso da influência

pessoal derivada muitas vezes do status social passa a tomar o lugar dos direitos.

Segundo MANZINI-COVRE (1991, p. 10):

só existe cidadania se houver a prática da reivindicação, da apropriação de espaços, da pugna para fazer valer os direitos do cidadão. Nesse sentido, a prática da cidadania pode ser a estratégia, por excelência para a construção de uma sociedade melhor. Mas, o primeiro pressuposto dessa prática é que esteja assegurado o direito de reivindicar os direitos, e que o conhecimento deste se estenda cada vez mais a toda a população. (MANZINI-COVRE 1991, p. 10).

As práticas sociais de lazer, turismo, esporte e cultura - que são direitos fundamentais estabelecidos na Constituição brasileira - de acordo com Moesch (2012):

(...) não buscam o consumo passivo, substituto analgésico de outras carências. Ao contrário, resgatam o valor da urbanidade, da tradição, da vida pública de troca, do respeito e do conhecimento do outro a partir de políticas direcionadas ao cidadão, sujeito mais amplo que o pretendido pela terminologia mercadológica que o reduza. (MOESCH, 2012, p.205).

O componente cidadania, neste sentido, vem a ser uma avanço proposto pelas autoras na concepção de turismo e na construção de políticas públicas que devem ser de fato comprometidas com o seu âmago, sua essência, que é propiciar o bem-estar comum a todos, indistintamente.

Portanto, a "cidadania turística, é uma maneira de repensar comportamentos e consumos de viagem". (GASTAL e MOESCH, 2007). Ela também permite rebater os discursos simplistas que reduzem o turismo como apenas atividade econômica. Uma nova perspectiva pode e vem sendo construída em cidades turísticas e esta ocorre mediante conhecimento das comunidades receptivas em relação a seus deveres e direitos no Turismo além da reivindicação destes.

A cidadania pode ser entendida como um conceito aberto, um conceito-rede, e que não termina com mais uma conquista. Não há como dizer que se é um cidadão completo, pois enquanto seres inacabados os homens estarão sempre 
buscando, descobrindo, criando e, por consequência dessa procura, ampliando seus direitos.

Cidadania resulta na efetivação dos direitos e na luta incessante para alcançá-los, independente da condição pessoal ou social do individuo e do corpo coletivo, implicando também o cumprimento de deveres.

\subsubsection{RELAÇÕES CAPITAL E TRABALHO}

A Revolução Industrial, caracterizada pela evolução tecnológica aplicada na produção, transforma o modus operandi do mundo do trabalho e das relações sociais. Isso não se dá apenas na forma de se produzir, mas também na forma da apropriação do trabalho pelo capital, que promoveu a separação do trabalhador de seus meios de produção.

As relações entre o capital e o trabalho já são há muito tempo uma preocupação da maioria dos economistas, mas também dos sociólogos, psicólogos, dentre outros teóricos de diversos campos do conhecimento.

Adam Smith foi o primeiro autor a perceber que uma nova situação se estabelecia, no seu livro "A Riqueza das Nações" de 1776, ele analisa pela primeira vez as relações entre capital e trabalho. $O$ autor parte de uma situação hoje raramente encontrada em que o mercado tem livre concorrência, com produtos homogêneos, com pleno conhecimento dos produtos e serviços tanto pelos produtores como pelos consumidores, e onde a regulação dos preços se faz de modo automático pela "mão invisível do mercado".

Para os economistas clássicos, a riqueza não era a prata ou o ouro entesourada como entendiam os mercantilistas, nem era apenas a agricultura a fonte de todas as riquezas como os fisiocratas afirmavam, mas a prosperidade de uma nação, era proveniente do trabalho humano.

O trabalho é a moeda que homologa todos os bens, que permite as transações, sendo fonte de renda e riqueza. Para eles a condição de ser rico ou pobre depende da vontade do indivíduo, depende da quantidade de trabalho que se pode oferecer ou comprar, por esse motivo defendiam a ausência de interferência governamental de qualquer forma na economia e chegavam mesmo 
a utilizar argumentos religiosos para defender suas ideias.

Portanto, o capital e o trabalho foram tratados por eles como mercadorias e assim sujeitos à lei de "livre concorrência", sem nada que limitasse o valor do trabalho, sendo a taxa salarial um arranjo social resultante da capacidade de negociação entre os capitalistas e os trabalhadores.

No entanto, esse era um processo contínuo de negociação desequilibrada, já que existiam mais trabalhadores - especialmente por terem migrado em grande número dos campos para as cidades - do que proprietários dos meios de produção. Enquanto as leis proibiam os trabalhadores de se organizarem para solicitar melhores salários e condições de trabalho, ao contrário nada impedia os capitalistas de desvalorizarem o trabalho.

Enquanto os capitalistas detém a propriedade privada dos meios de produção, resta apenas aos trabalhadores a sua força de trabalho ${ }^{47}$, sendo expropriados do valor total do produto de seus trabalhos, já que diferentemente de outrora, o que lhes cabia era apenas o salário pago pelo capitalista.

A divisão do trabalho, a mecanização eram os principais fatores que aumentavam a produção.

Na percepção de Smith e Ricardo, o motor do sistema capitalista está na acumulação e na inversão dos excedentes por parte dos capitalistas, o que legitimaria essa desigualdade produtiva. Embora condenassem a pobreza e a desigualdade extremas - apesar de reconhecerem que o capitalismo produz tais desigualdades - acreditavam no crescimento como redutor da pobreza extrema, mas não da desigualdade, da ordem social ou dos direitos de propriedade. Confiavam na benevolência das pessoas para diminuir tal desigualdade.

As longas jornadas diárias de trabalho, os baixíssimos salários recebidos, a exploração do trabalho feminino e infantil, caracterizaram a condição existencial dos trabalhadores.

É neste contexto da Revolução Industrial, em que o capitalismo já se encontrava bem estabelecido nos países mais industrializados da Europa, que

\footnotetext{
${ }^{47}$ Para Marx, a força de trabalho corresponde à capacidade de trabalho, referindo- se a um conjunto das faculdades físicas e mentais de que os indivíduos dispõem e podem mobilizar, colocar em ação, para produzir objetos de qualquer espécie que se constituem em valor de uso. No processo de produção, a força de trabalho entra na relação de consumo e adquire um valor que é determinado pelo tempo de trabalho necessário à sua produção, e por consequência, à sua reprodução.
} 
partindo de uma posição filosófica e crítica em face da história, Karl Marx (sem desconsiderar as contribuições de Engels), elaborou a teoria social sobre 0 capitalismo. No cerne de suas preocupações estava o problema das relações de produção.

Compreendendo a teoria do valor-trabalho enquanto indispensável para a análise das relações de produção do regime capitalista, Marx reconhece nela embora diferentemente da perspectiva dos economistas clássicos, que aceitavam a exploração da força de trabalho -, "o fundamento da doutrina da mais-valia ${ }^{48}$, que em última instância, é a anatomia da luta de classes no regime capitalista". (Furtado, 1986, p.15).

Para Marx, o produto que o capitalista compra e que o trabalhador vende não é o trabalho, mas sim a capacidade de trabalho, a força de trabalho.

A força de trabalho para Marx distingue-se das mercadorias porque a sua produção não ocorre dentro das condições mercantis, de modo que não é produzida "no" nem "para" o mercado, e, distintamente das mercadorias, que transferem apenas o seu próprio valor, o consumo da força de trabalho gera um valor excedente (o qual é apropriado pelo capitalista). Ademais, diferentemente tal qual ocorre com as mercadorias, o valor de uso da força de trabalho não se transfere às mãos do comprador (capitalista) imediatamente após o contrato de compra e venda.

A transformação da força de trabalho em mercadoria resultou de um longo processo histórico que originou o trabalhador "livre": Livre em dois sentidos, pois é proprietário da sua capacidade de trabalho, (não é escravo), e, por ser destituído das condições necessárias ao uso dessa capacidade, isto é, dos meios de produção, neste sentido, é "livre" então para o capital.

Dois fenômenos peculiares ocorrem no processo de trabalho, em seu percurso enquanto processo de consumo da força de trabalho pelo capitalista, conforme colocado por Marx e Engels (2013):

[Primeiro:] O trabalhador trabalha sob o controle do capitalista a quem pertence seu trabalho. $O$ capitalista cuida para que o trabalho se realize em ordem e os meios de produção sejam empregados conforme seus

\footnotetext{
${ }^{48}$ Para Marx a mais-valia consiste na apropriação pelo capitalista de uma determinada quantidade de trabalho não pago, ao trabalhador. Marx considerava que esta seria a base do lucro no sistema capitalista.
} 
fins,portanto, que não seja desperdiçada matéria-prima e que o instrumento de trabalho seja preservado, isto é, só seja destruído na medida em que seu uso no trabalho o exija. Segundo: o produto porém é propriedade do capitalista, e não do produtor direto, do trabalhador. A sua utilização, como a de qualquer outra mercadoria (...) pertence-lhe (...) A partir do momento em que ele [trabalhador] entrou na oficina do capitalista, o valor de uso da sua força de trabalho, portanto sua utilização, o trabalho pertence ao capitalista. (MARX e ENGELS, 2001, p.304).

Para Marx e Engels, o tipo de troca que ocorre entre o capital e o trabalho é que produz a mais-valia, servindo de base não só à produção e acumulação capitalista, mas ao mesmo tempo ao "sistema de trabalho assalariado" 49 ", que tem de conduzir, sem parar, "à constante reprodução do operário como operário e do capitalista como capitalista" (MARX e ENGELS apud ANTUNES, 2013, p.75).

Cabe ressaltar, que neste contexto de exploração dos trabalhadores, surgiram movimentos reivindicatórios que se organizaram politicamente em sindicatos, por melhores condições de trabalho, que resultaram na "conquista de benefícios que aliviaram, no transcorrer dos séculos XIX e XX, a exploração do trabalho pelo capital (...) tais como: assistência médico hospitalar, jurídica e previdenciária, extensão do direito universal do voto (...)" (Oliveira, 2006.p.84), dentre outras.

Para Marx a justiça na redistribuição de renda e a melhoria das condições de vida dos trabalhadores só seria possível pela luta de classes.

Ao final do século XIX e início do século XX, com o advento do fordismo e do taylorismo, o modo de produção capitalista industrial, transformou novamente as formas de produção e de trabalho, alterando profundamente a configuração das relações de capital e trabalho.

As mudanças deste período foram tão intensas, que pode se afirmar que os trabalhadores sofreram transformações não só em termos materiais mas também ocorreram profundas repercussões na subjetividade, afetando a forma de ser destes. Esse período é caracterizado pelo avanço tecnológico como a

\footnotetext{
${ }^{49}$ Marx critica o intervencionismo estatal. Para ele as leis, regulamentos e políticas, viabilizaram além da destruição das condições de acesso aos trabalhadores aos meios de produção, ajudou a impor o trabalho assalariado, sancionando a completa subordinação do trabalho ao capital no âmbito da produção. Milton Santos também faz uma crítica à instituição do "salário mínimo" no Brasil, para ele, a atribuição de uma "quantidade mínima de dinheiro capaz de assegurar uma vida decente para cada qual e sua família, não pode ser estabelecida em função dos simples mandamentos da "economia", mas da cultura".(SANTOS, 2012, p.17). Para ele, o FGTS no Brasil, é uma outra falácia institucionalizada do não-trabalho, uma vez que "encoraja a rotatividade e consagra a nãoassistência" (SANTOS, 2012, p.32)
} 
automação, a robótica, a microeletrônica que passam a dominar o espaço fabril, inserindo-se e desenvolvendo-se nas relações de trabalho e de produção do capital.

Aliado a tecnologia, a racionalização das atividades industriais traduzida no modelo "eficiente da linha de produção" desenvolvido por Henry Ford, garantiu a ampliação dos lucros.

A concepção de produção desenvolvida por Taylor, conhecida como taylorismo é baseada em um método científico de organização do trabalho. Tal modelo caracterizou- se pela ênfase nas tarefas, de forma a fragmentar o trabalho, visto que cada trabalhador passa a exercer uma atividade específica na produção industrial. A organização foi hierarquizada, sistematizada e o tempo de produção passou a ser cronometrado o que propiciava por sua vez um aumento da eficiência ao nível operacional, traduzida em maior produtividade e consequentemente em maior acumulação de capital.

Por outro lado, esse padrão produtivo taylorista e fordista intensificava as formas de exploração do trabalhador uma vez que reduzia a ação do operário a um conjunto repetitivo de atividades, Ihes tirando autonomia do trabalho paralelamente à perda da destreza do trabalhador.

Esse processo de:

(...) desantropomorfização do trabalho e sua conversão em apêndice da máquina-ferramenta dotavam o capital de maior intensidade na extração do sobretrabalho (...) A subsunção real do trabalho ao capital, própria da fase da maquinaria, estava consolidada. (ANTUNES, 2000, p.37)

Cabe ressaltar que o taylorismo e o fordismo além de terem transformado a produção industrial capitalista, expandiram-se em princípio para toda a indústria automobilística dos Estados Unidos e depois para praticamente todo o processo industrial nos principais países capitalistas - ocorrendo a sua expansão inclusive para grande parte do setor de serviços. Tais processos foram também embriões de outros processos produtivos, tais como neofordismo, neotaylorismo, dentre outros.

No entanto, por volta do final dos anos de 1960, o modo de produção industrial nestes moldes passa a dar sinais de esgotamento, já que encontravase estruturalmente comprometido dado o contexto político-econômico á época, originando um processo de mutação do sistema estabelecido. Para Antunes (2000), a crise do taylorismo e do fordismo, se deu como expressão 
fenomênica da crise estrutural do capitalismo.

Cabe salientar que esse momento é marcado pela eclosão de diversas revoltas dos trabalhadores, dada as condições de trabalho advindas dos métodos taylorista e fordista além do:

(...) descontentamento em relação ao caminho social democrata do movimento operário predominante nos organismos de representação do (ou sobre o) mundo do trabalho (...) o que estava no centro da ação operária [era] a possibilidade efetiva do controle social dos trabalhadores dos meios materiais do processo produtivo. (ANTUNES, 2000, p.40-42)

A transição que se deu a partir de então é caracterizada em uma reorientação produtiva á qual David Harvey denomina de "acumulação flexível", pois o caráter "rígido" da produção nos moldes fordistas, passa a ser alterado por uma produção de caráter "flexível", que se apoia na flexibilização dos processos de trabalho (especialmente o modelo toyotista, já consolidado no Japão e que espalha-se pelo mundo a partir de então), mas também dos mercados de trabalho e dos produtos e padrões de consumo.

O cronômetro, a produção em série e de massa, que outrora foram alavancadores do crescimento e da acumulação de capital são agora substituídos pela "flexibilização", logo essa nova dinâmica que se dá na produção, gera desdobramentos em relação aos direitos trabalhistas, uma vez que a mobilidade do capital aumenta, permitindo que os empregadores exerçam pressões cada vez mais fortes de controle do trabalho, sobre uma força de trabalho já enfraquecida.

Outros fenômenos marcam o mundo do trabalho no último século: os níveis altos de desemprego estrutural; a ocorrência de uma rápida destruição e reconstrução das habilidades, permeada por ganhos modestos de salários reais; aumento da fragmentação no interior da classe trabalhadora; retrocesso do poder sindical. "A acumulação flexível envolve rápidas mudanças dos padrões do desenvolvimento desigual (...) entre setores, criando, por exemplo, um vasto movimento no emprego no chamado setor de serviços". (HARVEY, 2012, p.140), ou seja, parte dos trabalhadores industriais de outrora, tornaram-se trabalhadores do setor de serviços.

O processo de transição da condição moderna fordista para a pós moderna flexível - usando os termos de Harvey - tem em seu âmago contradições, e , no que tange ao modo de produção e ao trabalho elas podem ser elencadas 
corroborando com as reflexões de Harvey (2012, p.304), ilustrada no quadro abaixo:

QUADRO 2 - Características do modo de produção capitalista "Fordista" e do modo de produção capitalista "Flexível".

\begin{tabular}{|l|l|}
\hline \multicolumn{1}{|c|}{ Fondição Moderna } & $\begin{array}{c}\text { Condição Pós moderna } \\
\text { Acumulação Flexível }\end{array}$ \\
\hline Economia de escala & Economia de escopo \\
\hline Universalismo & Localismo \\
\hline Capital produtivo & Capital fictício - financeiro \\
\hline Materialidade & Imaterialidade \\
\hline Poder do Estado & Poder Financeiro \\
\hline Produção em massa & $\begin{array}{l}\text { Produção em pequenos lotes - } \\
\text { exclusivismo }\end{array}$ \\
\hline Regulação & Desregulação \\
\hline Indústria & Serviços \\
\hline Divisão detalhada do trabalho & Divisão social do trabalho \\
\hline Operário & Administrador - colaborador \\
\hline Tarefa única & Tarefas múltiplas \\
\hline Trabalho especializado & Trabalho flexível \\
\hline Ética protestante do trabalho & Contrato temporário \\
\hline Sindicatos & Individualismo \\
\hline Paranóia & Esquizofrenia \\
\hline Alienação & Descentração \\
\hline & \\
\hline
\end{tabular}

Fonte: Elaborado pela autora, adaptado de Harvey (2012). 


\section{CAPÍTULO III. PIRENÓPOLIS: LIMITES E POSSIBILIDADES DE TRANSFORMAÇÃO DAS PRÁTICAS SOCIOECONÔMICAS PELO TURISMO - DESAFIOS PARA UM DESENVOLVIMENTO SUSTENTÁVEL E INCLUDENTE}

Levando em consideração a teoria apresentada anteriormente no cenário histórico-estrutural sobre desenvolvimento, turismo, políticas públicas e as relações de capital e trabalho, neste capítulo, empenhamo-nos em responder de forma mais específica o problema de pesquisa norteador desta dissertação, que é entender se o Turismo pode vir a ser um novo instrumento de transformação das práticas socioeconômicas na cidade de Pirenópolis rompendo ao continuísmo das tradicionais formas capitalistas de exploração do território, desvelando os limites e possibilidades de um desenvolvimento sustentável includente.

Em um primeiro momento, faremos alusão aos sujeitos reprodutores do turismo - neste caso, o Ministério do Turismo, Agência Estadual de Turismo, e a Secretaria de turismo, planejamento urbano e desenvolvimento econômico sustentável de Pirenópolis, buscando analisar e esclarecer as intencionalidades contidas nos documentos oficiais e referenciadas nas entrevistas. Em seguida, analisaremos os processos e produtos que são originados pela e na estrutura social presentes nas ações e nos discursos dos sujeitos consumidores, representados pelos empreendedores e trabalhadores do turismo de Pirenópolis.

\subsection{OS SUJEITOS REPRODUTORES DO TURISMO - Ministério do Turismo e Secretaria de Turismo de Pirenópolis.}

Embora o recorte temporal desta investigação esteja centrado entre os anos de 2003 a 2013, é necessário entender a implementação das políticas públicas estabelecidas tanto pela gestão pública federal como estadual e municipal anteriores a esse período elencado.

As políticas públicas de turismo da esfera estadual passam a ser implementadas em Pirenópolis somente no final da década de 1980. Ações como qualificação, levantamento de informações sobre atrativos e potencialidades turísticas, além de ações de marketing - já que o objetivo da gestão estatal era de dar visibilidade ao estado de Goiás - foram as que ocorreram no município. O turismo fora desde o princípio encarado pela gestão pública estadual como somente 
uma atividade econômica, tanto que vinculada desde à Secretaria de Comércio e Indústria.

A partir da década de 1990, é que de forma mais incisiva as políticas públicas em nível federal passam a ser executadas no município, sobretudo após o tombamento do patrimônio arquitetônico do centro histórico realizado pelo IPHAN em 1989, que abriu passagem para o aumento de demanda turística. A implementação do PED no município nesta década, embora tenha deixado um legado como a criação do Centro de Atendimento ao Turista, a qualificação, dentre outras, como podemos observar com Almeida (2002), não foram efetivas, pois os objetivos do programa não foram alcançados, devido à "falta de responsabilidade compartilhada por todos os agentes sociais, governamentais e não governamentais". (ALMEIDA, 2002, p.211).

O PNMT no município também não conseguiu atingir seus objetivos devido a diversos fatores, como a limitação financeira do município, a política partidária contrária aos interesses da coletividade e até a falta de pessoas especialistas em Turismo á frente da gestão municipal.

A política pública estadual estabelecia e ainda estabelece uma forte parceria com o SEBRAE - conforme depreendido dos documentos, literatura, e inclusive das entrevistas realizadas - que no município teve papel preponderante promovendo o planejamento estratégico da "cadeia produtiva" de Turismo, ou seja, o enfoque das ações era dado á iniciativa privada.

No âmbito da política municipal, foram criados a Secretaria de Cultura e Turismo além do Conselho Municipal de Turismo, no entanto a Secretaria dispunha de um orçamento pífio, o município não dispunha nem de um Fundo de Turismo, as ações da secretaria eram centradas mais no apoio á realização das festas populares tradicionais.

O Conselho que era composto em sua maioria por representantes de órgãos públicos municipais, existia somente no papel, na lei, uma vez que não havia reuniões e nem proposição de ações e pactuação com os entes envolvidos, estando em estagnação até a década seguinte. Este fato revela que a criação dessas instâncias de governança foram efetivadas para somente atender a demanda de descentralização e democratização expressa na política federal (especialmente do PNMT), não havendo o envolvimento de fato da comunidade. 
Portanto, essas políticas em nível federal e estadual não lograram muitos avanços, sequer conseguiram colocar em prática todas as ações intencionadas, sobretudo por que não haviam informações e um programa contínuo de sensibilização junto á comunidade para a compreensão em relação á complexidade do turismo além de um incentivo ao engajamento desta, uma vez que as ações foram especialmente voltadas ao atendimento das demandas da iniciativa privada e da relação oferta-demanda, como marketing, consultoria ás empresas, qualificação de empreendedores, inventariação turística.

É a partir do início da década de 2000 que passa a ocorrer em Pirenópolis uma intensificação não só de investimentos privados mas também de investimentos pela gestão pública estadual em marketing, participação do estado e seus municípios em feiras e congressos de turismo e diversos eventos culturais, que perduram até os dias atuais. Festivais realizados em Pirenópolis como o "Canto da Primavera" e o "Festival Gastronômico", são dentre os diversos festivais criados e financiados pelo estado - além da tradicional Festa do Divino e Cavalhadas - que promovem mídia direta para o turismo de Goiás, pois sua divulgação é ampliada para a escala regional. Há ainda festivais promovidas pela iniciativa privada e ONGS com o apoio da gestão pública estadual e municipal que a cada ano surgem, a exemplo do Piri Bier e Slow Film.

A criação do Ministério do Turismo em 2003 e a implementação do primeiro Plano Nacional do Turismo (2003-2007) representam um avanço em termos de política pública do turismo com a proposição da "gestão descentralizada e participativa, redução das desigualdades regionais e sociais, a geração e distribuição de renda, a geração de emprego e ocupação, e o equilíbrio do balanço de pagamentos", entendendo o turismo "como elemento propulsor do desenvolvimento socioeconômico do país".

No entanto, a análise do plano revela que o turismo é concebido de fato, na perspectiva economicista, como uma atividade interessante para aquecer a economia. Como se o crescimento econômico fosse necessariamente propiciador de "desenvolvimento econômico e social”, numa relação linear de causa-efeito.

O plano se traduz na integração do turismo à macro estratégia do país, se comprometendo a cumprir um papel funcional e fundamental no crescimento econômico e na "redução das desigualdades sociais" (via geração de emprego e renda e via abordagem territorial da regionalização, como se esses dois fatores 
fossem os únicos responsáveis por cumprir esse papel) - mas não no desenvolvimento integral e integrador.

Conforme constatado no plano há um quadro de dependência em relação ao fluxo turístico especialmente internacional para alavancar a economia do turismo, inclusive com o estabelecimento de metas quantitativas em relação á geração de emprego, aumento de divisas, e ampliação da oferta turística, apresenta dessa forma dependência total da dinâmica do mercado global, portanto, a iniciativa privada é vista como o fundamental parceiro para o "desenvolvimento" do turismo, pois este é um "negócio" que deve gerar dividendos para a balança comercial nacional. Essa crença, que continua até hoje, na concepção dos gestores da política do turismo nacional, reflete-se nos objetivos dos Planos Nacionais de Turismo, e seus programas, o que a partir da teoria social capital/trabalho, ideologicamente imprime uma legitimidade as relações exploratória do capital tanto em nível do território, como das relações de produção e sociais estabelecidas nas localidades entendidas como turísticas, a exemplo de Pirenópolis.

Já os trabalhadores das Atividades Características do Turismo (ACT's) são concebidos enquanto peças de engrenagem para a operacionalização do "sistema turismo", de forma que o investimento na qualificação proposto pelo plano serve de suporte para que o "setor turístico" se beneficie, e para que se atinja a "qualidade do produto turístico", com vistas ao aumento da competitividade do país no cenário turístico internacional e ao aumento de divisas.

No âmbito estadual, no ano de 2003 a AGETUR, autarquia estatal responsável pelo turismo (atual Goiás Turismo) em parceria com o SEBRAE formulou um programa denominado "Caminhos de Goiás" que destacava as regiões turísticas do estado, tendo como objetivo trabalhar essas regiões para atração de investimentos e visitantes. Pirenópolis fazia parte do "caminho do ouro" - atualmente denominada região do ouro, da qual ainda é integrante - e como parte deste programa foram desenvolvidas no município pesquisas de oferta e demanda, oficina de sensibilização e articulação junto aos órgãos competentes para a implementação da infraestrutura de apoio turístico.

Na prática esse programa de "regionalização" se traduzia e ainda se traduz em roteirização, com o estabelecimento de "roteiros temáticos" e foi base do Plano Estadual de Turismo (2003-2006). As diretrizes e estratégias operacionalizadas nas 
regiões turísticas ocorreram através de 4 programas voltados à divulgação e marketing, informação, infraestrutura e produtos turísticos.

A política pública estadual estabelece uma forte parceria com o SEBRAE conforme depreendido dos documentos e da literatura - e tem papel preponderante promovendo o planejamento estratégico da "cadeia produtiva" de Turismo, portanto, o enfoque das ações é dado á iniciativa privada.

A "roteirização" perdurou como base no Plano Estadual de Turismo - PET vigente (2008-2011), que possui como foco a estratégia da competitividade, operacionalizada pelos programas de: 1) planejamento e gestão (que tem como proposta a descentralização, mas não a democratização, já que considera somente as entidades públicas e privadas como os únicos entes do turismo, e tem como objetivo "disseminar" as políticas públicas nas regiões e nos municípios; 2) Informações e Estudos Turísticos (monitoramento de competitividade e ofertademanda); 4) Infraestrutura Pública; 5) Qualificação do Produto; 6) Promoção e Apoio a Comercialização.

Os programas para o "desenvolvimento do turismo" revelam a visão mercadológica do turismo, assim como o Programa Nacional de Regionalização que limita-se a uma "roteirização" que de forma alguma propicia um desenvolvimento sustentável da localidade/regiões pelo turismo como podemos constatar com Beni (2006):

\begin{abstract}
O que temos visto com muita frequência são cenários de roteirização regionalizada em vez de regionalização sustentável do turismo (...) O próprio SEBRAE, que poderia ser o grande parceiro e coadjuvante do MinTur no Programa de Regionalização do Turismo por sua inegável experiência em lidar com o desenvolvimento local e regional sustentável, mudou seu foco e trabalha outras frentes e prioridades no Sistema de Turismo (...) A roteirização regionalizada pode servir momentaneamente para o marketing de destinos e para ampliar o fluxo turístico para algumas regiões a curto prazo, mas de maneira alguma é o caminho para estabelecer e consolidar o turismo como instrumento de desenvolvimento sustentável. (BENI, 2006, p.32).
\end{abstract}

E o Plano Estadual de Turismo PET (2008-2011), revela essa concepção mercadológica que o estado tem sobre turismo, perpetuando e disseminando tal lógica aos municípios.

O turismo é uma atividade econômica muito sofisticada e suscetível a interferências por fatores exógenos, portanto precisa de acompanhamento em tempo real. Mais do que receitas prontas, as estratégias para o turismo no Estado, demandam a gestão de informações voltadas ao interesse 
econômico. (...) Goiás pode também oferecer destinos turísticos muito exclusivos, focados em segmentos específicos, de menor volume e maior rentabilidade.(...) Não se trata de uma receita acabada, mas de um conjunto de estratégias que devem ser dinâmicas na busca interminável de se adequar às demandas sempre surpreendentes e inovadoras do mercado turístico regional, nacional e mundial. (PET, 2008, p.13).

Os autores do PET-GO (2008) atribuem desmedidamente à iniciativa privada a responsabilidade sobre o desenvolvimento do turismo em Goiás, chegando a expressar que os "empresários da capital" - Goiânia - devem expandir sua influência no interior, ampliar os debates e serem reconhecidos pelos poderes políticos e demais setores econômicos.

Essa perspectiva revela que o modelo de planejamento e governança local implantado em Goiás, atua como instrumento de influência e força política sobre os destinos, beneficiando, prioritariamente, as lideranças tradicionais e seus interesses econômicos. Demonstrando que as práticas "coronelistas" de outrora ainda se fazem presentes, inclusive no turismo. Logo, a sociedade civil sequer é contemplada como partícipe do processo de planejamento e gestão do turismo.

Em âmbito nacional, o Plano Nacional de Turismo (2007-2010), traz algumas alterações e atualizações em seus objetivos e programas como a Sustentabilidade, Competitividade, inclusão social, planejamento e gestão participativa e descentralizada, foco no turismo interno demarcando uma intenção de aprofundar o processo de desenvolvimento local.

A proposta de planejamento e gestão descentralizada e participativa passa a ganhar força, especialmente sendo uma das ações estruturantes do Programa de Regionalização do Turismo - PRT - existente desde 2004 - um dos carros-chefes desse novo plano. Este programa propõe a "estruturação, o ordenamento e a diversificação da oferta turística e se constitui no referencial da base territorial do plano" (BRASIL, 2007, p.67), a proposta é balizada pela segmentação tanto da demanda quanto da oferta.

O fomento a produção artesanal, um dos objetivos contidos no PRT tem o intuito de alavancar a oferta turística, agregar valor ao produto turístico potencializando a competitividade dos "produtos turísticos", ou seja, a produção artesanal é tratada de forma funcionalista, numa espécie de subserviência ao turismo. Este fomento se traduz em ações de divulgação, comercialização em feiras e cursos de qualificação, essas ações propostas são apenas pontuais que surtem 
efeitos efêmeros e que não se desdobram em um desenvolvimento sustentável e includente.

Pensar o território junto à comunidade e ajudar a fomentar as diversas atividades por meio de uma relação mútua e equilibrada entre estas, seria uma possibilidade de promover a inclusão e o desenvolvimento sustentável, afinal conforme destacado no capítulo II a sustentabilidade econômica e social deve ocorrer dentre outras premissas por meio de um desenvolvimento econômico intersetorial e equilibrado, com a participação e organização popular e equidade na distribuição de renda e de diminuição das diferenças sociais (SACHS, 2008).

A inclusão social é uma nova perspectiva que o plano traz, inclusive sendo seu mote principal. De acordo com o plano a inclusão social "pode ser alcançada por duas vias: a da produção por meio da criação de novos postos de trabalho ocupação e renda e a do consumo com a absorção de novos turistas no mercado interno" (BRASIL,2007, p.11), ou seja, a ideia da "produção" e "consumo" já evidencia o forte apelo econômico do turismo que ainda perdura neste plano.

A geração de emprego e renda não pode ser a garantia de uma inclusão social caso esta não se traduzir em condições dignas de trabalho. O desenvolvimento includente deve ser fundamentado em um trabalho decente para todos (SACHS, 2008), portanto a proteção social, as condições de trabalho materiais e não materiais, a obtenção de uma renda justa compatível com as necessidades do trabalhador são essenciais neste sentido.

O consumo por si só não é sinônimo de inclusão social e de cidadania, esse posicionamento dos entes produtores da política pública não emitindo outras alternativas para o acesso ao turismo, lazer, cultura que não unicamente no campo do mercado, corroborando com Santos (2012), continua a reproduzir a formação em lugar do cidadão de um consumidor.

Embora sejam estabelecidos programas com vistas à "inclusão" pelo acesso das camadas mais pobres e as minorias da sociedade ao turismo, a exemplo do Viaja Mais Melhor Idade, tais programas não devem ser estabelecidos como estratégia de solução para o problema da sazonalidade que ocorre no turismo (haja visto que a oferta de "produtos turísticos" para essas camadas com preços acessíveis, se da nos períodos considerados de baixa temporada). Ora se o objetivo é a democratização do "consumo", então os preços deveriam ser acessíveis a essas minorias da sociedade em qualquer época do ano. 
Agora se o intuito for a inclusão de fato pelo turismo, a perspectiva deve ser outra. Neste sentido, é possível pensar a cidadania associada ao turismo? O turismo pode contribuir para a construção da cidadania e vice-versa?

Ao compartilhar com o posicionamento de Gastal e Moesch (2007) que entendem ser possível aplicar questões de cidadania ao turismo, especialmente, por serem os fluxos e os fixos imprescindíveis ao fenômeno, e logo, igualmente os sujeitos que o realizam: os turistas, afirma-se o turismo como prática social. Para tal tarefa, as autoras, propõem a utilização da cidadania como metodologia; análoga a proposta de Meksenas (2001), que concebe cidadania como um conceito rede.

"Deslocar-se significa sair das rotinas espaciais e temporais, e viver o estranhamento causado pela nova situação". (GASTAL e MOESCH, 2007, p. 38).

Neste sentido, para as autoras, o papel desenvolvido pela comunicação deve estar centrado na contribuição para uma aproximação fraterna e solidária com o outro, aquele com quem o turista se depara quando sai de sua casa: a comunidade receptiva; o diferente.

Portanto, para as autoras, as políticas de comunicação deveriam avançar nesse sentido indo para além da intermediação da experiência turística, via fornecimento de conteúdos informativos - até mesmo por que em tempos de globalização e tecnologia, o turista procura por si só informações sobre o destino antes de viajar - mas concebendo o turismo como a possibilidade de mediação, como colaborador para a construção da cidadania.

A associação entre cidadania e turismo, prescinde também de políticas públicas do turismo, que podem contribuir em diversos aspectos para a construção da cidadania. De acordo com Gastal e Moesch (2007), as políticas públicas devem ter como objetivos: a contribuição com a melhoria da qualidade de vida da comunidade local e consequentemente dos turistas; que elas impulsionem o surgimento de novos atores locais e, consequentemente, de novos valores, crenças e desejos, de modo a que eles constituam em fortalezas para turismo local; que sejam instrumentos de desenvolvimento econômico e social, não tendo um fim em si mesmo; que o selo de identidade local, agregado ao destino, seja garantido não por certificações exógenas, e sim pela qualidade cultural local, visto que cada cultura faz melhor do que as demais aquilo que lhe é de autoria. 
Além disso a política pública do turismo deve ter como objetivo a democratização do Turismo, possibilitando que a hospitalidade e o lazer sejam acessíveis de fato a todos, tanto aos visitantes quanto aos cidadãos.

Neste sentido, a associação entre cidadania e Turismo, se daria em duas propostas: centrada na figura do cidadão turista, aquele morador que através do deslocamento, do movimento apropriar-se-ia dos espaços, dos fixos de sua cidade, proporcionando assim que este construa uma relação de pertencimento e identificação com a cidade; e posteriormente avançando na proposta, para o turista cidadão, que trata se do:

(...) habitante que desenvolve um relacionamento diferenciado com o local onde mora no seu tempo de lazer, quebrando o modelo existencial da sociedade industrial criticado por Jost Krippendorf (trabalho-moradia-lazerviagem), de acordo com o qual o lazer - as práticas sociais capazes de restabelecer o equilíbrio físico e emocional do sujeito contemporâneo - só seria possível em lugares distantes da própria residência. (...) falar em turista cidadão seria avançar no conceito, e supor o sujeito formado e politicamente atuante nessas práticas. O sujeito que entendeu os fixos precisa apropriar-se dos fluxos ${ }^{50}$, neles compreendida a sua própria situação de um sujeito em trânsito, para nela colocar a subjetividade, aprendendo a expressá-la no mundo. (...) Turista cidadão é aquele que resgata a cultura da sua cidade, fazendo uso do estranhamento da mesma. Este estranhamento inicia no momento em que o indivíduo descobre, no espaço cotidiano, outras culturas, outras formas étnicas e outras oportunidades de lazer e entretenimento.(...) este sujeito aprende a utilizar os espaços ambientais, culturais, históricos, comerciais e de entretenimento com uma percepção diferenciada do seu cotidiano (GASTAL e MOESCH, 2007, p.60; 65).

No que tange à concepção de desenvolvimento sustentável, o PNT (20072010), apresenta alguns avanços quando comparado ao PNT (2003-2007) , como a ação de proteção á crianças e adolescentes, no que tange a erradicação da exploração sexual infantil pelo turismo, no entanto, ainda não contempla a totalidade do que seria um desenvolvimento sustentável e includente.

Embora haja o reconhecimento pelo PNT (2007-2010) de que os impactos econômicos, sociais, ambientais, políticos e culturais gerados pelo turismo exigem um monitoramento e avaliação, contraditoriamente o plano traz somente em um de seus programas a ação de avaliação dos impactos gerados na economia, o que revela que a preocupação e atenção com a sustentabilidade se dá somente considerando a dimensão econômica desta, pois a maioria dos objetivos propostos

\footnotetext{
${ }^{50}$ Fluxos entendidos não somente do ponto de vista da mobilidade física no território, mas de adesão aos fluxos de ideias e de outras expressões culturais, sejam elas globais ou locais (MOESH; GASTAL, 2007, p.65).
} 
estão voltados para atender aos interesses do mercado e para a reprodução do capital.

A competitividade é expressa de forma pujante, sobretudo nos PNT's (20072010) e (2013-2016). Uma das metas do PNT (2007-2010) é estruturar 65 destinos indutores com padrão de qualidade internacional.

A estratégia competitiva do Governo do Estado de Goiás, seguindo as diretrizes nacionais, optou em priorizar investimentos e ações nas cidades que já tinham a atividade turística de forma mais consolidada, como uma estratégia de indução ao desenvolvimento dos outros destinos menos atrativos, para dessa forma ocorrer a consolidação de Goiás como destino turístico nacional e internacional.

Pirenópolis tem se beneficiado dessa lógica, com recursos oriundos do estado especialmente para a realização de eventos culturais como o Festival Gastronômico e apoio na realização de pesquisas de demanda.

O programa nacional de competitividade do turismo "65 destinos indutores" foi implementado em 2008 em Pirenópolis, pois o município foi um dos selecionados pelo MTUR para fazer parte deste grupo seleto, e este é um dos programas que tem repercutido de forma mais influente no município de Pirenópolis como podemos depreender da entrevista com a gestão municipal:

Quanto a atuação de Pirenópolis como destino indutor, na minha visão, tem sido bastante efetiva, participando de todas ações voltadas aos 65 destinos indutores. A gente usa os indicadores das 13 dimensões do índice de competitividade para planejar as nossas ações, inclusive o destino já foi premiado algumas vezes pelo Ministério. (relato do entrevistado gestor municipal, 2015).

Pirenópolis foi premiada por três vezes pelo MTUR. Em 2011 foi à premiação de "melhores práticas dos 65 destinos indutores" que lhe rendeu o prêmio por evoluir na dimensão "aspectos culturais ${ }^{51 " . ~ E m ~} 2013$ por ter apresentado um bom desempenho na dimensão "marketing e promoção do destino ${ }^{52 " ~ e ~ e m ~} 2014$ na dimensão "monitoramento 53".

\footnotetext{
${ }^{51}$ Nesta dimensão são consideradas as variáveis (i) produção cultural associada ao turismo; (ii) patrimônio histórico e cultural; e (iii) estrutura municipal para apoio à cultura.

${ }^{52}$ Nesta dimensão são consideradas as seguintes variáveis: (i) plano de marketing; (ii) participação em feiras e eventos; (iii) promoção do destino; e (iv) estratégias de promoção digital.

${ }^{53}$ Esta dimensão considera os seguintes quesitos: (i) pesquisa de demanda; (ii) pesquisa de oferta; (iii) sistema de estatísticas do turismo; (iv) medição dos impactos da atividade turística; e (v) setor específico de estudos e pesquisas.
} 
As premiações nestas dimensões e a análise do relatório dos índices de competitividade $^{54}$ evidenciam que as ações - empreendidas tanto no âmbito municipal como no estadual - estão centradas na promoção do destino, na divulgação, na criação de uma imagem, no monitoramento de oferta e demanda, tendo um fim em si mesmo.

Esse posicionamento beneficia diretamente 0 mercado e não necessariamente o município e seus cidadãos, já que um aumento no fluxo turístico resultante de tais ações, não necessariamente propicia um aumento na geração de empregos formais e não precarizados, e nem a distribuição de renda.

Na prática esse programa em Pirenópolis tem sido um fim em si mesmo, pela visibilidade que acaba proporcionando ao "destino", já que não há evidências pujantes de indução dos demais destinos da região, apenas ações isoladas como a existência de uma página promocional na internet agregando informações dos municípios integrantes da região, além da disponibilidade nos Centros de Atendimento ao Turista de material promocional da região turística à qual está inserido. Conforme revelado nos estudos de competitividade. "O destino não compartilhou projetos de cooperação regional com outros destinos da mesma região" (BRASIL, 2012, p.28).

O Plano Municipal de Turismo (2012) fora elaborado sob orientação do SEBRAE. O plano é desconexo e apresenta ações desarticuladas umas das outras, além de diversas contradições no próprio discurso.

O plano mais se assemelha a um inventário ou diagnóstico de turismo do município, com a enumeração de algumas ações. Sendo o turismo concebido enquanto "importante instrumento transformador da economia local" (PMT, 2012, p.13), logo a parceria entre poder público e entidades privadas é encarada como relevante tendo como intuito "organizar a atividade turística e promover a sustentabilidade" (PMT, 2012, p.9). Sustentabilidade esta entendida de forma fragmentada, pois as poucas ações que tratam de sustentabilidade, aparecem sob a perspectiva cultural e ambiental, não condizendo desta forma com um planejamento integral do turismo.

\footnotetext{
${ }^{54}$ Os relatórios de índices de competitividade específicos de Pirenópolis analisados foram os de 2011 e de 2014, pois foram os únicos disponibilizados gentilmente pela gestão municipal, o próprio gestor municipal informou que não tinha em poder os relatórios dos demais anos e que inclusive já havia solicitado ao MTUR diversas vezes mas que ainda não tinha sido atendido em sua solicitação.
} 
Apesar da relevância dada ao programa "destino indutor" pela gestão pública municipal, a grande maioria dos empresários entrevistados desconhecem tanto a política de destino indutor como a política municipal, e quando já "ouviram falar" denotam que não a compreenderam (apenas um empresário soube explicitar o que é a política nacional, e a de destino indutor), conforme evidenciado nas entrevistas:

destino indutor acho que ouvi falar desse "trem" mas não tô lembrando mais nada, mas acho que a gente escutou num curso da Abrasel que teve uns 8 anos atrás, daí eles deram uma palestra e falaram desse negócio de destino indutor lá. (...) conhecimento tenho de que existe um plano municipal de turismo mas eu nunca participei, eu nem sei o que é porque eles reúne entre eles lá não avisa ninguém e pronto né, é uma reunião assim "vapt vupt" eu mesmo não recebi nenhum convite para participar (relato do entrevistado empresário de alimentação, 2015).

Não conheço esse destino indutor mas o plano municipal já tenho conhecimento. No meu ponto de vista a preocupação [do plano municipal] tem sido mais em exposição da cidade. (relato do entrevista empresária de meio de hospedagem, 2015).

As entrevistas revelam ainda que há certa centralização de poder por parte da gestão pública.

\begin{abstract}
O Secretário aglutina tudo pra si mas pelo menos ele faz e quer fazer, então ele é testa de ferro, ele é "fazedor", mas acabou ficando sozinho porque expulsou todo mundo também... como os condutores... mas ele pelo menos faz lá a tarefa, as principais linhas para manter o turismo sob controle de qualidade, isso ele faz (...) a política de destino indutor eu conheço um pouco né porque o secretário já faz todo o dever de casa. (relato do entrevistado empresário de meio de hospedagem, 2015).
\end{abstract}

Grande sorte nossa que temos um belo secretário de turismo que consegue ter carta na manga com Ministério do Turismo e com o governo porque Pirenópolis se desenvolveu, cresceu e vem melhorando e o secretário de turismo é o cara que "tá" conseguindo fazer tudo (relato do entrevistado empresário de atrativo turístico e alimentação, 2015).

Uma política pública de turismo será eficiente e democratizante quando implantada por uma administração que seja capaz de ouvir e incorporar a participação do trade turístico e da comunidade local (GASTAL e MOESCH, 2007).

Entretanto é relevante reconhecer que há uma apatia por parte da comunidade pirenopolina em participar dos processos de planejamento e gestão do turismo. O plano municipal de turismo contou com a participação de apenas 20 participantes sendo 6 representantes da gestão pública e os demais em sua maioria 
foram representantes do trade, conforme depreendido do próprio Plano Municipal de Turismo.

Apesar da participação ter sido aberta a todos a presença nos encontros se manteve praticamente a mesma houve um grupo interessado durante todo o processo no entanto alguns estiveram somente em momentos pontuais. (Plano Municipal de Turismo, 2012, p.14).

Esse posicionamento da sociedade civil em não participar do processo de planejamento e gestão do turismo, em certa medida, advém muitas vezes do descrédito em relação às instituições que orientam o processo de planejamento, mas também da burocracia, morosidade e frustração da comunidade em ver que seus anseios embora tenham sido contemplados no papel, raras vezes são concretizados, como evidenciado nas entrevistas.

A gente antes procurava sempre participar das reuniões de Comtur, Sebrae e tudo o mais, mas daí acontece um negócio chato que a reunião vira "ruinião", porque toda vez você vai sempre para discutir as mesmas coisas, aí você começa a não mais participar, você começa a não querer mais se envolver, aí a gente acaba se isolando porque se você for se envolver nesse "mundo" você não faz mais nada... Porque é a reunião de não sei o quê, amanhã é reunião de não sei o quê lá... e isso porque eu não vejo resultado... Se fosse objetivo conseguiria... uma vez só resolvia o assunto... agora vai passando de pauta em pauta e a coisa vai aumentando. (relato entrevistado empresário de atrativo turístico e alimentação, 2015).

O SEBRAE convidou pra participar de um plano que fazia uma rota de cidades turísticas... que vai juntando com um tal de "quintais de Goiás", num sei o quê... porque cada hora é um "babado", conforme vem um palestrante lá, ele vem mais "iluminado" e a coisa vai lá.... mas a coisa [rota de cidades turísticas] era legal, tipo pra todo os empresários se unir, mas é que os ânimos realmente são muito diferentes e na hora que o pessoal teve que participar financeiramente...porque todo mundo tava achando que era investimento do governo, todo mundo saiu fora, aí todo mundo achou que "tavam" querendo tirar proveito, que todo mundo tava sendo enganado, que ninguém sabia que ia ter que investir, tava todo mundo achando que ia só receber, né daí não ficou quase ninguém, tanto que eles [SEBRAE], vieram se despedir da gente aqui. (relato entrevistado empresária de meio de hospedagem, 2015).

Há ainda uma frustração (devido a mobilização e a expectativa que são gerados) em relação aos projetos de plurais instituições que chegam a Pirenópolis e que não são posteriormente concretizados como: Museu da Mineração, Projeto Estrada Colonial do Planalto Central, Caminhos de Cora Coralina, Projeto Expositores do Artesanato. E quando o são, ocorrem de forma incompleta a exemplo do Projeto Beira Rio. 
No que tange ao ordenamento físico territorial, o plano diretor do município passa atualmente por um processo de alteração. O plano vigente fora elaborado em 2002, e embora traga a proposição e comprometimento em realizar diversos projetos e ações, na prática, passados mais de 10 anos a maioria dessas proposições não passaram do papel e as que se concretizaram não o foram em sua totalidade. $O$ saneamento básico por exemplo de fundamental importância, sobretudo para o perímetro urbano não se concretizou.

Um plano diretor deve ser um instrumento de ordenação do município como um todo, entretanto, o plano vigente não traz a proposição de ações a nenhum dos povoados que compõem o município, como Lagolândia, Caxambu, dentre outros. E esta lógica perdura também nas políticas públicas do turismo, conforme revelado em entrevista com a gestão municipal.

Embora a atividade agropecuária seja a segunda em geração de PIB do município desde $1999^{55}$, esta não é contemplada pela gestão pública. As atividades de mineração de quartzito, artesanato e turismo são priorizadas, fazendo parte do programa de geração de emprego e renda proposto pelo plano.

A maioria das orientações e proposições do plano está voltada ao desenvolvimento da atividade turística. O ecoturismo e o turismo histórico cultural, segmentos priorizados pelo plano para o desenvolvimento do turismo, não dispõe de projetos ou ações voltadas à educação patrimonial, e, ambiental e nem de monitoramento e avaliação de impactos ambientais e culturais advindos do turismo.

Há três projetos de parques lineares propostos no plano, no entanto na prática o único projeto que foi implantado denominado "Beira Rio", não foi realizado em sua totalidade e abarcou somente 0 trecho em que 0 rio passa pelo centro histórico, parte da cidade em que há mais evidência das atividades características do turismo e de fluxo turístico. Ademais os equipamentos de lazer (à exceção de melhoria do campo de futebol que já existia para a prática de esportes), iluminação especial e praças urbanizadas previstas no projeto sequer foram concretizados.

O plano traz a dimensão de sustentabilidade do município a partir da perspectiva de uma "cidade justa, ecológica e atrativa", há evidências no plano de que a intenção de ser uma cidade atrativa significa atrair turistas, para tanto a

\footnotetext{
${ }^{55}$ conforme constatado pelos dados IMB/SEPLAN (análise período 2003 a 2012)
} 
"preservação do patrimônio histórico arquitetônico, urbanístico e paisagístico da cidade e de seu entorno", se faz necessária.

A "valorização" de determinados "espaços públicos" com o intuito de "dinamizar a atividade turística", denota um posicionamento empreendedor por parte da gestão pública do município.

(...) a abordagem "administrativa", tão característica da década de 1960, deu lugar a formas de ação iniciadoras e "empreendedoras", nas décadas de 1970 e 1980. Nos anos recentes parece haver um consenso geral emergindo em todo o mundo capitalista avançado: os benefícios positivos são obtidos pelas cidades que adotam uma postura empreendedora em relação ao desenvolvimento econômico. (HARVEY, 2005, p.165).

Há que se considerar que esse consenso difundido de forma global de que esses benefícios positivos estão atrelados a posicionamentos empreendedores, perpassa também nos partidos políticos e nas ideologias, sendo mote utilizado tanto nos discursos políticos, como nas concepções das políticas públicas e planejamentos urbanos em todos os níveis.

Como as reverberações da globalização rebatem no local, as cidades pequenas não estão imunes á lógica capitalista de "empreendedorismo urbano", sobretudo as pequenas cidades-patrimônio, a exemplo de Pirenópolis, que, apropriadas pelo turismo atendem á lógica da dialética da construção destrutiva ${ }^{56}$, que de acordo com Costa (2012), esta:

diz respeito a contradição imperante entre a "preservação" e a mercantilização, a busca da democratização e da "elitização" do patrimônio urbano, de forma ampla, e das destinações turísticas, particularmente. A partir desta noção, podemos afirmar que o conflito entre "preservação" e mercantilização - princípio interno do ordenamento territorial dos lugares patrimonializados - só se mantém com a permanente vitória da mercantilização, mas sem a banalização total da "preservação", ou dos objetos, pois depende destes para se efetivar. Esse processo contraditório catalisa-se na corrida de encontro da cultura com a mercadoria, é um processo de construção-desconstrução que se operacionaliza simultaneamente - circunscrito por um movimento ininterrupto só entendido na relação entre particularidade e universalidade das destinações turísticas - na consagração dos bens culturais e naturais do mundo. (COSTA, 2014, p.12).

O processo de desenvolvimento do turismo em Pirenópolis não adotou princípios de sustentabilidade e não aparenta atualmente se preocupar com 0

\footnotetext{
${ }^{56}$ Conceito elaborado pelo autor, Prof. Dr. Everaldo Batista da Costa em sua tese de mestrado em Geografia.
} 
desenvolvimento sustentável e includente em suas dimensões ambiental, social, cultural, econômica e política.

Nas esferas cultural e ambiental tanto o patrimônio natural, as cachoeiras, as unidades de conservação e a paisagem, quanto o patrimônio cultural material e imaterial, o saber-fazer da comunidade local, são entendidos em uma perspectiva mercadológica passando a servir de base para a reprodução do capital.

$\mathrm{Na}$ esfera política somente os entes públicos e o trade turístico são considerados como partícipes do processo de desenvolvimento do turismo. O território é tratado de forma fragmentada, em que o rural e a sua produção artesanal aparecem como recurso potencial de atrativo turístico, mas pouco é assistido em suas necessidades de ordenação e produção qualificada pela gestão pública.

A "melhoria da qualidade de vida" da população, a "geração de emprego e renda" defendida nos discursos dos diferentes planos se transfiguram em empregos precarizados, rendas pífias e informalidade.

$\mathrm{Na}$ esfera econômica, mesmo com a insuficiência de dados econômicos precisos, dado que o PIB de serviços não traduz a economia do turismo, os aumentos do fluxo turístico e de empreendimentos privados passam a ser a expressão do crescimento econômico, do desenvolvimento em si.

\subsection{OS SUJEITOS CONSUMIDORES DO TURISMO - Empresários e Trabalhadores do Turismo.}

Em um esforço por analisar as relações de capital e trabalho para compreender quais as influências destas na caracterização do processo de desenvolvimento do turismo de Pirenópolis, foi realizada uma análise dos documentos e programas oficiais de turismo, análise de dados disponibilizados pela gestão municipal acerca dos empreendimentos turísticos, e os dados oficiais sobre emprego e renda do Ministério do Trabalho Emprego e Renda.

As entrevistas realizadas com diversos empreendedores e trabalhadores do turismo as quais balizadoras para a compreensão destas relações e o desvelamento se há ou não continuísmo das tradicionais formas capitalistas de exploração do território em suas práticas de reprodução capital/trabalho pelo turismo no município, 
A Política Nacional de Turismo ao reproduzir a concepção global de turismo de caráter majoritariamente econômico (turismo como instrumento propiciador de desenvolvimento, este entendido na perspectiva de crescimento) difunde esta ideologia para as esferas estaduais e municipais do planejamento e gestão do turismo.

Diante deste cenário, a iniciativa privada é o grande parceiro da gestão pública na proposição e execução de ações que visam "reduzir as desigualdades sociais", uma vez que estes são vistos como os únicos que tem capacidade de "gerar renda".

Nesta lógica capitalista, os trabalhadores do turismo são concebidos em duplo sentido: como força de trabalho para produção e reprodução de capital, portanto uma peça de uma engrenagem maior, e como consumidores potenciais.

Daí a ideia simplista de "inclusão social" defendida pelas políticas públicas de turismo, "inclusão" pelo emprego, sem cogitar as condições de emprego e de renda, e "inclusão" pelo consumo.

Contraditoriamente ao mesmo tempo em que o MTUR assinala nos três últimos planos elaborados que o turismo é uma "atividade econômica" geradora de emprego e renda, revela não ter dados quantitativos confiáveis que confirmem tal afirmativa. Embora houvesse, desde 2006, uma metodologia desenvolvida pelo IPEA, junto ao MTUR na tentativa de entender os empregos gerados pelo turismo, os estudos e pesquisas foram realizados de forma esporádica, não se traduzindo em um processo contínuo o que possibilitaria um panorama histórico para melhor orientar as políticas locais no que tange ao emprego e renda.

No entanto, é reconhecível que avanços têm ocorrido a partir de 2012, quando a metodologia passou a produzir dados melhor sistematizados e de forma periódica, retratando o panorama das atividades características do turismo do Brasil e das unidades federativas.

Não obstante existam programas de Sistemas de Informações do Turismo em nível estadual, e ações em nível municipal, expressos nas respectivas políticas públicas estes estão centrados na aferição de dados relativos a oferta e demanda.

O sistema de informações do turismo do estado de Goiás, tem por objetivo desenvolver um sistema permanente para coleta, organização, análise e disseminação de dados turísticos, com prioridade para pesquisas de mercado e perfil de demanda (segmentos prioritários). (PET, 2007, 15). 
Não há uma preocupação do estado de Goiás em saber se há de fato geração de emprego e renda pelo turismo, sequer quais são as condições de trabalho desses trabalhadores e o respeito a seus direitos, no entanto há uma preocupação com a arrecadação de impostos com a implantação da nota fiscal eletrônica. A questão de dúvida recai sobre como a arrecadação é revertida para contemplar as demandas sociais da comunidade de Pirenópolis, por exemplo?

A tabela abaixo, elaborada com dados oficiais retrata os aspectos socioeconômicos do município de Pirenópolis.

TABELA 1: Indicadores socioeconômicos e PIB (2012) - Pirenópolis

\begin{tabular}{|c|c|c|c|c|c|c|c|}
\hline \multicolumn{4}{|c|}{ Participação no PIB Local (2012) } & \multirow{3}{*}{$\begin{array}{c}\text { PIB 2012 } \\
\text { (R\$ mil) }\end{array}$} & \multirow{3}{*}{$\begin{array}{l}\text { População } \\
\text { (2010) }\end{array}$} & \multirow{3}{*}{$\begin{array}{l}\text { IDHM } \\
\text { (2010) }\end{array}$} & \multirow{3}{*}{$\begin{array}{c}\text { Incidên } \\
\text { cia da } \\
\text { pobreza }\end{array}$} \\
\hline \multirow[b]{2}{*}{$\begin{array}{l}\text { Agro } \\
\text { pecuária }\end{array}$} & \multirow[b]{2}{*}{$\begin{array}{c}\text { Indús } \\
\text { tria }\end{array}$} & \multicolumn{2}{|c|}{ Serviços } & & & & \\
\hline & & $\begin{array}{c}\text { Comercio/ } \\
\text { outros }\end{array}$ & $\begin{array}{c}\text { Adm. } \\
\text { Pública }\end{array}$ & & & & \\
\hline $25,8 \%$ & $18,9 \%$ & $33,30 \%$ & $22,05 \%$ & 248.650 & 23.006 & 0,693 & $33,20 \%$ \\
\hline
\end{tabular}

Fonte: IBGE/IPEA/IMB, 2014. Elaborado pela autora.

Podemos depreender desse panorama que embora o setor terciário seja 0 maior representante da economia do município, as demais atividades são ainda relevantes na composição da economia local. Há que se considerar ainda que nem todas as atividades de serviço necessariamente são a expressão da economia do turismo.

Com o intuito de garantir maior rigor fiscal, a gestão municipal implantou em 2013 um sistema que dispõe de um módulo de "nota fiscal eletrônica" com um sistema "on line" para os empreendedores emitirem suas notas fiscais. A própria gestora da secretaria de finanças reconhece que após a implantação do sistema houve um aumento na arrecadação de impostos, contudo reconhece que alguns prestadores de serviços ainda resistem a adesão.

Temos tido alguma dificuldade, principalmente, com o setor hoteleiro. Algumas pousadas ainda resistem à emissão de nota fiscal ou tentam "burlar" o sistema. Por isso, estamos planejando ações para conscientizar os donos de pousadas sobre a importância da nota.(relato verbal da gestora municipal de finanças, 2015). 
Segundo ela, o sistema é de fácil utilização e são oferecidos ainda treinamentos aos empreendedores sobre a sua correta utilização.

No entanto, os dados disponibilizados pela gestão municipal no que tange as empresas turísticas revela que há discrepâncias de informações entre as secretarias de turismo e de finanças, curiosamente a secretaria de turismo dispõe de dados mais próximos da realidade do que a secretaria de finanças.

$\mathrm{Na}$ ocasião da abordagem a gestora municipal de finanças reconheceu que o sistema implantado apresenta falhas, o que inclusive impossibilitou a disponibilização de todos os dados solicitados dos anos do recorte temporal desta investigação.

Contudo, para a análise recorremos aos dados fornecidos pela secretaria de turismo, que segundo o gestor municipal de turismo se apresentam atualizados. Oportuno ressaltar o reconhecimento da gestora de finanças de que há um movimento flutuante nos números de empresas, pois a cada dia abrem mais empresas no município ligadas ao turismo.

TABELA 2 : Quantidade de empreendimentos das Atividades Características do Turismo (ACT) - 2013.

\begin{tabular}{|l|c|}
\hline \multicolumn{1}{|c|}{$\begin{array}{c}\text { Atividades Características } \\
\text { Turismo (ACTS) }\end{array}$} & 2013 \\
\hline Alojamento & 202 \\
\hline Agência de Viagem & 11 \\
\hline Transporte & 11 \\
\hline Alimentação & 79 \\
\hline Cultura e Lazer & 27 \\
\hline TOTAL DAS ACTS & 330 \\
\hline
\end{tabular}

Fonte: Secretaria de Turismo, Planejamento Urbano e Desenvolvimento Econômico Sustentável, 2013. Elaborado pela autora. 
Analisando os dados referentes a $2013^{57}$, do total da ACT Alojamento, 168 empreendimentos estão na categoria pousadas, 16 campings e 18 suítes, dentre o total desta ACT, 113 empreendimentos estão cadastrados no MTUR e 14 fazem parte da Associação Brasileira da Indústria de Hotéis de Goiás - (ABIH-GO).

Já a ACT Alimentação tem um total de 79 empreendimentos, sendo que 7 estão cadastrados no MTUR e de acordo com as informações da secretaria municipal, 11 são integrantes da Associação Brasileira de Bares e Restaurantes de Goiás - (ABRASEL-GO). No entanto, no site da ABRASEL-GO nenhuma empresa de Pirenópolis aparece como associada à entidade.

Na ACT Cultura e Lazer são 27 atrativos cadastrados, sendo 11 atrativos naturais (1 cadastrado no MTUR) e 16 atrativos culturais. Já a ACT Transportes somam 11 empresas sendo 4 cadastradas no MTUR.

A ACT agência apresenta 11 agencias de turismo receptivo, todas cadastradas no MTUR, contudo somente 5 destas agências tem pontos físicos abertos para atendimento ao público.

Podemos depreender dos dados que há um número expressivo de empreendimentos turísticos no município especialmente de meios de hospedagem.

A Secretaria de turismo criou uma lei em 2011 estabelecendo para as empresas a obrigatoriedade de Cadastro Nacional de Pessoas Jurídicas para a emissão de alvará de licença do município, o próprio gestor municipal de turismo informou que desde 2012 não é permitida a disposição de materiais de divulgação nos Centros de Atendimento ao Turista de empreendimentos informais, e nem de participação em feiras de turismo em que a gestão municipal participe. Segundo ele a secretaria tem feito um esforço por cadastrar os empreendimentos no MTUR (em atendimento à demanda da gestão estadual e do MTUR), e tem conseguido nos últimos anos adesão de muitos empresários neste sentido.

Apesar de todas essas ações o gestor municipal reconhece que há ainda uma imaturidade dos empresários do setor de serviços e comércio ligados ao turismo.

\footnotetext{
${ }^{57}$ Foram analisados somente os dados de 2013,pois a gestão municipal não dispõe de dados anteriores a esse período.
} 
Em Pirenópolis, sentimos que uma das maiores dificuldades para o desenvolvimento turístico é a falta de capacidade empresarial ${ }^{58}$, a qual desde 2008vem recebendo a menor nota de todos os itens avaliados pela FGV. (...) sentimos que os empresários, ainda, precisam de maior maturidade do setor. (relato da entrevista com gestor municipal de turismo, 2015).

A partir dos dados analisados, sobretudo das entrevistas referentes aos empreendimentos turísticos, a afirmativa de imaturidade do empresariado pôde ser evidenciada, especialmente daqueles que estão há menos tempo no "negócio do turismo". Esse posicionamento em certa medida deva-se ao perfil das pessoas que empreendem no município, que geralmente se mudam para Pirenópolis buscando melhor qualidade de vida e acabam por se aventurar e empreender no turismo, como complementação de renda ou hobby, uma vez que em sua maioria não dependem dos lucros do "negócio" do turismo.

agora parece que tá um "boom", como vai abrindo loteamento ninguém tá nem aí... e o pessoal, goianienses e brasiliense, os aposentados, tá todo mundo vindo pra cá abrir um "negocinho", né. (relato da entrevista com empresária de meio de hospedagem, 2015).

Contudo a exemplo de outros municípios turísticos do Brasil, com o aumento do fluxo de investimentos locais em infraestrutura devem ocorrer ampliando a visibilidade do "destino", a tendência é a chegada de empreendedores melhor capacitados, de acordo com Beni (2006) essa é a terceira fase de desenvolvimento pela qual os destinos turísticos geralmente passam, quando começa o ingresso massivo de capitais nacionais e até internacionais.

A maioria dos empreendedores entrevistados tem uma concepção de turismo mais ligada à ideia de "deslocamento", "lazer" e "experiência", do que propriamente uma "atividade econômica", mas reconhecem o turismo como a "atividade" mais relevante para a economia do município. Tal percepção acerca do turismo depreendida pelos empreendedores, poderia ser uma entrada para uma proposta mais sistêmica e humanizada a do turismo local.

Desenvolvimento é entendido na perspectiva de "crescimento econômico", acumulação de capital, conforme evidenciado nas entrevistas à exceção de alguns.

\footnotetext{
${ }^{58} \mathrm{O}$ Estudo de Competitividade considera os seguintes quesitos de avaliação referentes à Capacidade empresarial: (i) capacidade de qualificação e aproveitamento do pessoal local; (ii) presença de grupos nacionais e internacionais do setor de turismo; (iii) concorrência e barreiras de entrada; e (iv) geração de negócios e empreendedorismo
} 
Contraditoriamente sustentabilidade é entendida pelo menos no discurso, por parte dos empreendedores locais, considerando as perspectivas social, econômica, ambiental e a maioria dos entrevistados, participam de alguma ação de responsabilidade social, os que não desenvolvem ações em suas empresas, apoiam ou participam de ONGS. Contudo são pequenas ações, ligadas especialmente às questões ambientais como a coleta seletiva de lixo, apenas um empresário diz participar de ações sociais em uma comunidade educacional que é um "ponto de cultura, e, um outro que diz ter parceria com a Universidade local recebendo um aluno de gastronomia para fazer estágio.

A maioria dos empresários entrevistados revelaram comprar em torno de $75 \%$ seus insumos na cidade mesmo, apenas dois entrevistados revelaram que compram $50 \%$ dos insumos utilizados em Pirenópolis e a outra metade na cidade de Anápolis, contudo apenas um entrevistado diz fazer suas compras no município pelo motivo de que desta forma "fomenta a economia local".

Apesar da existência de associações representativas de setores empresariais, como a ABRASEL e ABIH, não há uma adesão significativa de empresários a estas associações. As ações destas entidades são esporádicas, geralmente ocorrem em atendimento às demandas das entidades do nível estadual.

As entrevistas ainda revelaram que embora tenha ocorrido no passado em certa medida processos colaborativos entre empresários, atualmente não há mais a cooperação e união, nem entre os empresários que não participam de tais associações, e quando há alguma ação em comum é somente para atender à questões emergenciais.

\begin{abstract}
A gente vai participar da $\mathrm{ABIH}$, porque meu esposo conheceu o presidente local da ABIH e simpatizou com ele, e a gente também achou legal porque é um valor tão pequeno de mensalidade, e realmente precisa ter alguma coisa que todo mundo, todos os empresários vá junto, quando acontece alguma coisa como essa do ECAD, do PROCON... e eles também são mais políticos, então é interessante.(relato da entrevista com empresária de meio de hospedagem, 2015).

O pessoal da $\mathrm{ABIH}$ tem se reunido agora lá por causa do negócio do "Time Share" ${ }^{\text {, }}$, por que "parece" que tem dois projetos que já foram aprovados de 200 ou 300 apartamentos sem aprovação do novo plano diretor...e eu não
\end{abstract}

\footnotetext{
${ }^{59}$ Time share, ou tempo compartilhado, é uma modalidade de "negócio" turístico que permite ao consumidor adquirir o direito de usufruto num determinado meio de hospedagem, por um período de tempo mediante a aquisição de um título de afiliação e o pagamento de uma taxa de manutenção periódica.
} 
faço parte da $\mathrm{ABIH}$, mas nós os empresários estamos querendo se reunir na quarta feira e fazer uma maneira agora de barrar isso. (relato da entrevista com empresário de meio de hospedagem).

Quando perguntados sobre qual seria o maior desafio de seu negócio, apenas um empresário mencionou a sazonalidade, pois a demanda maior ocorre aos finais de semana. No entanto todos os demais se queixaram da falta de qualificação da "mão de obra", e da falta de "compromisso" da mesma para com o trabalho.

Os problemas aos quais a entrevistada se refere ao ECAD e PROCON, ela esclarece que foram ações jurídicas movidas por tais instituições aos empreendimentos ligados ao turismo, especialmente aos meios de hospedagem.

No caso do ECAD era para imputar cobrança por direitos autorais aos estabelecimentos que dispõe de aparelhos como televisão e rádio e fazem uso destes como forma de entretenimento para a prestação do serviço de hospedagem e de alimentação. E no caso do PROCON foi uma ação movida inibindo a "venda casada", pois em Pirenópolis a grande maioria dos meios de hospedagem de certa maneira forçam o cliente adquirir mais de uma diária nos finais de semana, justamente devido ao problema da sazonalidade. O outro problema relatado em relação ao PROCON, foi devido a não devolução ou devolução parcial ao cliente do depósito (pagamento) antecipado das diárias por parte dos meios de hospedagem, uma vez que o PROCON entendeu como uma infração ao direito do consumidor.

Tais situações denotam em outro aspecto a exploração do turista.

As entrevistas revelaram ainda que há um conflito cultural que permeia as relações entre empresário e trabalhador em dois sentidos:

a) primeiro no sentido de choque cultural no caso daqueles empresários oriundos de grandes centros urbanos como Brasília, São Paulo e Goiânia que não entendem a visão de mundo e até de nível de compreensão de seus trabalhadores devido ao baixo nível de escolaridade e formação profissional. Como a cosmovisão destes trabalhadores locais ao não entender a importância das festividades tradicionais na vida das pessoas da comunidade autóctone.

tem a questão cultural ne, de você formar a equipe, o valor que se dá pra o trabalho, por isso que pra formar uma equipe agora, nós temos os padrões as pessoas tem que ter uns requisitos, nós não empregamos mais pessoas jovens, "jovenzinhas", por que elas não se comprometem, por causa das festas e tal. E tem a questão da comunicação, por exemplo, quando a gente quer deixar um recado geral a gente coloca em um caderninho que a gente usa pra se comunicar, mas daí também o que se observa, é que as pessoas assinam sem ler, se o recado for muito grande, tipo se tiver 3 parágrafos, 
não lê... você tem que usar recursos tipo palavras em letras grandes, botar cores, sabe...eu já cheguei a falar "mas sua assinatura está aqui". (...) a gente fala também com eles da questão comportamental, de todo esse comportamento, né que "você não tá na porta da sua casa, nem o seu jeito de se vestir", aqui a gente tem até dificuldade no calçado, é a "cultura do chinelo", quando a pousada era bem "simplesinha", quando a gente comprou, até combinava a "cultura do chinelo", mas pra mudar isso foi a maior dificuldade, graças a deus eu consegui mudar a equipe, porque eu troquei, e quando as pessoas chegavam eu perguntava "você tem problema de usar tênis?, porque não pode você vai atender as pessoas mais finas, elas estão te olhando dos pés a cabeça". (relato da entrevista com empresário de meio de hospedagem, 2015).

Aqui é diferente, é uma cidade que ela vive de festa que as pessoas vivem momentos... Então é assim "trabalhei gastei tudo, trabalhei gastei" então é uma questão cultural mesmo, "eu" [trabalhador] largo do meu serviço para ir ver a chegada da "folia" agora a "minha" estabilidade financeira que fique para trás, vai ser depois da folia, e depois já vem a festa da capela então quer dizer, é aquela coisa e depois vem a festa do morro e as pessoas já falam assim "eu só volto a minha vida ao normal depois da festa da capela", então quer dizer... ela vai se capacitar? ela vai ser alguém pra entrar numa empresa e que a empresa vai virar pra ela e falar assim "meu amigo férias quem dá sou eu, não é no momento em que você quer"?... "então não vou poder ir para capela? não vou poder de ir para festa do morro?".

Então aqui não é igual em uma empresa que você tem que ter um currículo para entrar que no mínimo você tem que ter o segundo grau completo para entrar e ser alguma coisa lá...aqui não tem disso. "O que é currículo? pra quê currículo?" então é a criação, a forma que a pessoa foi criada. Então isso atrapalha muito o crescimento intelectual da pessoa "quem eu vou ser? o que eu vou ser?... "eu" vou ser mascarado, cavaleiro, ou folião $o^{60}$. (relato da entrevista com empresário de alimentação, 2015).

o pessoal empresário de fora ele vem, aí ele abre uma pousada legal, só que a forma que ele trata as pessoas só porque ele acha que tem pousada aqui, que mora aqui, ele acha que pode tratar as pessoas de qualquer forma, paga super mal e fica por isso mesmo. As pessoas que vão trabalhar, geralmente uma pessoa que não tem conhecimento, uma pessoa que não seja estudada, capacitada, eles até humilham, é bem constrangedor, porque a pessoa precisa do emprego então eu vejo muito isso, que eu escuto também sempre de outras pessoas daqui que "trabalha" pra essas pessoas que vêm de fora... tem restaurante aqui na cidade que dá o que sobra pro funcionário comer. (relato da entrevista com trabalhadora de meio de hospedagem, 2015).

b) segundo no sentido de o trabalho no turismo ser somente uma alternativa de trabalho preferida à extração e beneficiamento da pedra de quartzito, por que há menos esforço físico e menos insalubridade, além de ser uma atividade que se apresentou como alternativa para as mulheres e jovens trabalharem.

Por que essas pessoas não tem ganância, a ganância é ter de moto, som, casa ...o resto que é viajar, crescer, ensinar o filho, qualquer outra coisa assim, não tem. Então assim, tem as pessoas que para não trabalhar na pedreira elas acharam a "brecha" de trabalhar no turismo porque não tem

\footnotetext{
${ }^{60}$ Aqui o entrevistado faz referência às personagens que as pessoas assumem nos dias da festividade das Cavalhadas.
} 
opção de trabalho.(relato da entrevista com empresário de atrativo turístico e alimentação, 2015).

conforme o turismo foi "vindo" o trabalho começou a ficar escasso na pedreira, porque aumentou restaurante, aumentou pousada, e o pessoal da pedreira passou a trabalhar em restaurante e pousada e o que fez 0 pessoal da pedreira sair de lá foi porque a forma de trabalho é pesada, e nem os jovens querem trabalhar lá, é tanto que é só os mais "velho que trabalha" lá. (relato da entrevista com trabalhador da área de alimentação, 2015).

Apesar de a maioria dos empresários reconhecerem a importância da qualificação para o desenvolvimento de suas empresas e discursarem que incentivam seus trabalhadores a se qualificar, na prática seus discursos não se materializam. As entrevistas evidenciaram que apenas dois empresários propiciam condições materiais para que seus trabalhadores se qualifiquem: um pelo rearranjo no horário de trabalho e gratificações monetárias e o outro com auxílio no pagamento de cursos que não sejam gratuitos. $O$ incentivo fica mais no campo subjetivo e não material. Tal proposição foi confirmada quando confrontamos estes discursos com as entrevistas dos trabalhadores.

Incentivo para estudar tem por parte da proprietária, ela fala, mas assim nada mais (relato da entrevista com trabalhadora da área de meio de hospedagem, 2015).

Se eu tivesse a oportunidade de fazer cursos de qualificação, seria bem melhor... eu faria, porque daí a gente ia também saber né... o dono sempre fala assim que tem curso de computação, então quando tiver vaga e vocês quiserem fazer, mas é isso.(relato da entrevista com trabalhadora da área de meio de hospedagem, 2015).

Entretanto, é importante ressaltar que há também um desinteresse dos trabalhadores em se qualificar, as entrevistas revelaram que embora a grande maioria acredite ser importante a qualificação à exceção de um, poucos foram os que demonstraram interesse em fazer cursos.

Importante a qualificação é, mas às vezes conta mais o que a gente aprende no dia a dia do que aprender na escola, porque aqui em Pirenópolis o que mais vale é a experiência das pessoas, os donos não veem muito a qualificação, veem mais mesmo é a qualidade do serviço da pessoa, eu já ouvi dizer que a cidade tem alguns cursos de qualificação, mas eu não sei muito bem, aqui mesmo o dono fala pra gente quando tem curso na cidade. (relato da entrevista com trabalhadora da área de atrativo turístico e alimentação, 2015).

Eu não tenho curso de qualificação na área do turismo, mas eu não tenho dificuldade no que eu faço, se tivesse algum curso alguma coisa que aparecesse eu faria pra melhorar no caso né, mas não faz falta não. Aqui em Pirenópolis eu não vejo cursos, não sei se eles que não divulgam... eu 
não tenho acesso a informação, só na faculdade mesmo né, a UEG que sei que tem curso, eu trabalho na reserva com computador, mas nunca vi convite por email para cursos na área do turismo de qualificação não.(relato da entrevista com trabalhadora da área de meio de hospedagem, 2015).

Segundo o secretário de turismo apesar de a gestão municipal se esforçar na divulgação para as empresas e para a sociedade civil como um todo, os cursos de diferentes entidades como o SENAC,e os cursos do PRONATEC que são oferecidos no município, ele encontra sempre dificuldade para que as vagas sejam preenchidas, mesmo adequando os horários para atendimento das diversas ocupações no turismo.

\begin{abstract}
A gente procura adequar os horários para atender a todos né, então por exemplo, o curso de garçom a gente procura fazer a tarde porque a pessoa trabalhou a noite toda, como o pessoal que trabalha na "rua do lazer", então a pessoa precisa descansar de manhã, então a gente coloca o curso para 0 período da tarde. (relato da entrevista com gestor municipal de turismo, 2015).
\end{abstract}

agora sempre tem cursos profissionalizantes, mas eu por exemplo fico sabendo dos cursos "boca a boca" eu não vejo a prefeitura divulgando, não recebo e-mail e nem vejo carro de som na rua, agora o pessoal do SEBRAE eles passam e-mail, agora o pessoal da prefeitura não, eu fico sabendo de "boca a boca "mesmo, quando tem algum que chega e fala.(relato da entrevista com trabalhadora de meio de hospedagem, 2015).

Alguns fatos podem explicar em certa medida a razão dessa situação estabelecida no município: a) fica claro que existem problemas de comunicação entre a gestão municipal e a comunidade no tocante a divulgação dos cursos de qualificação, possa ser que os meios de comunicação usados não sejam muito eficientes, não atingindo parcela expressiva da comunidade; b) há uma relação antagônica entre os empreendedores e os trabalhadores, pois os primeiros reclamam que incentivam seus trabalhadores a se qualificar, mas que eles não demonstram interesse, já os segundos queixam-se porque recebem somente incentivos morais, mas que não se qualificam também por não lhes ser exigido tal qualificação.

Essa situação leva a uma espécie de círculo vicioso em que o empreendedor não exige qualificação pela característica da atividade desenvolvida, e muitas vezes porque não há muitos trabalhadores disponíveis no mercado de trabalho (conforme relatado por eles nas entrevistas) ,e na contramão, o trabalhador não se capacita porque a qualificação não lhe é exigida e há abundância de locais para trabalhar. 
Pirenópolis recebeu uma variedade de cursos de qualificação ao longo do tempo por diversas instituições. Os cursos de qualificação do programa Qualifica Goiás da Goiás Turismo ofertou a partir de 2009 os cursos de: qualificação dos serviços ao turista, qualificação dos atrativos turísticos, gestão de hotéis e pousadas, qualificação de cerimonial de eventos, qualificação de guia de turismo regional, sistema de gestão e segurança do turismo de aventura, gestão empresarial com foco no turismo de aventura, competências mínimas do condutor, foram doze turmas qualificadas, entretanto nem a Goiás Turismo, e nem a Secretaria de Turismo municipal, souberam informar exatamente quantas pessoas foram formadas em cada curso, somente que foram formadas doze turmas, entre dez a vinte pessoas, mas não souberam informar a quantidade exata de pessoas por cada turma e cada curso e se estas estão empregadas no setor de serviços e turismo.

Foram ainda ofertados cursos de qualificação pelos programas, Programa Senac de Gratuidade (PSG), Pronatec na Empresa, Pronatec Copa e Pronatec Turismo: inglês básico, inglês intermediário, inglês avançado, espanhol básico, espanhol intermediário, informática, organizador de eventos, auxiliar de cozinha, auxiliar de recursos humanos, guia regional de turismo, recepcionista, qualidade no atendimento, libras, camareira e garçom, foram 34 turmas, mas novamente nenhum órgão responsável pela realização e apoio aos cursos soube informar a quantidade exata de pessoas que foram qualificadas, embora tenha sido feito contato até com o Ministério do Turismo, no caso do Pronatec, para conseguir tal informação.

O que pôde ser depreendido das entrevistas é que as empresas em certa medida "treinam" seus trabalhadores, mas de forma esporádica e não efetiva. Dentre todos os entrevistados apenas um empresário reconheceu a sua responsabilidade em não capacitar e treinar seus trabalhadores.

A gente tem um déficit bem grande em termos de qualificação ${ }^{61}$. A gente
acredita que uma reunião coletiva fluiria mais, você separa os temas,
organiza né, lembra...então assim eu já dei passos muito grandes, tipo fazer
pasta pra os funcionários lerem as informações, pra relembrarem, então eu
pego e releio, porque isso é importante, é uma espécie de qualificação,
abordando desde como deve ser o tom de voz ao atender ao telefone, como
atender os turistas, e tudo isso... mas a gente percebe que se fosse mais
organizado, de forma mais frequente, e se a gente levasse a sério isso
mesmo, a importância que isso tem, seria menos desgastante e a própria

\footnotetext{
${ }^{61}$ Há uma confusão na compreensão do que vem a ser qualificação, a empresária confunde qualificação com treinamento e com capacitação.
} 
equipe mesmo, eles levariam o trabalho mais a sério.(relato da entrevista com empresária de meio de hospedagem, 2015).

Diante de tal quadro, em que não há um monitoramento efetivo das diferentes informações no que tange a qualificação, não há como estabelecer eficazes políticas públicas de qualificação na área do turismo, e nem tem como avaliar o mercado de trabalho no turismo. Quantos estão qualificados? Quais áreas há maior oferta de trabalhadores? O trabalho no turismo é formal ou informal? Quantas pessoas estão empregadas nos empreendimentos turísticos?

Analisando os dados da RAIS/MTE, considerando as ACTs, e o recorte temporal desta investigação, entre os anos de 2003 a 2013, foi possível traçar um panorama aproximado da realidade do emprego no município ${ }^{62}$.

Os dados analisados ao longo do período elencado evidenciaram que houve um aumento no número de empregos formais gerados.

Considerando todas as atividades características do turismo, em 2003 haviam 232 trabalhadores formalizados, já em 2013 foram 618 pessoas.

GRÁFICO 1 - Empregos formais considerando todas as Atividades Características do Turismo (2003 a 2013).

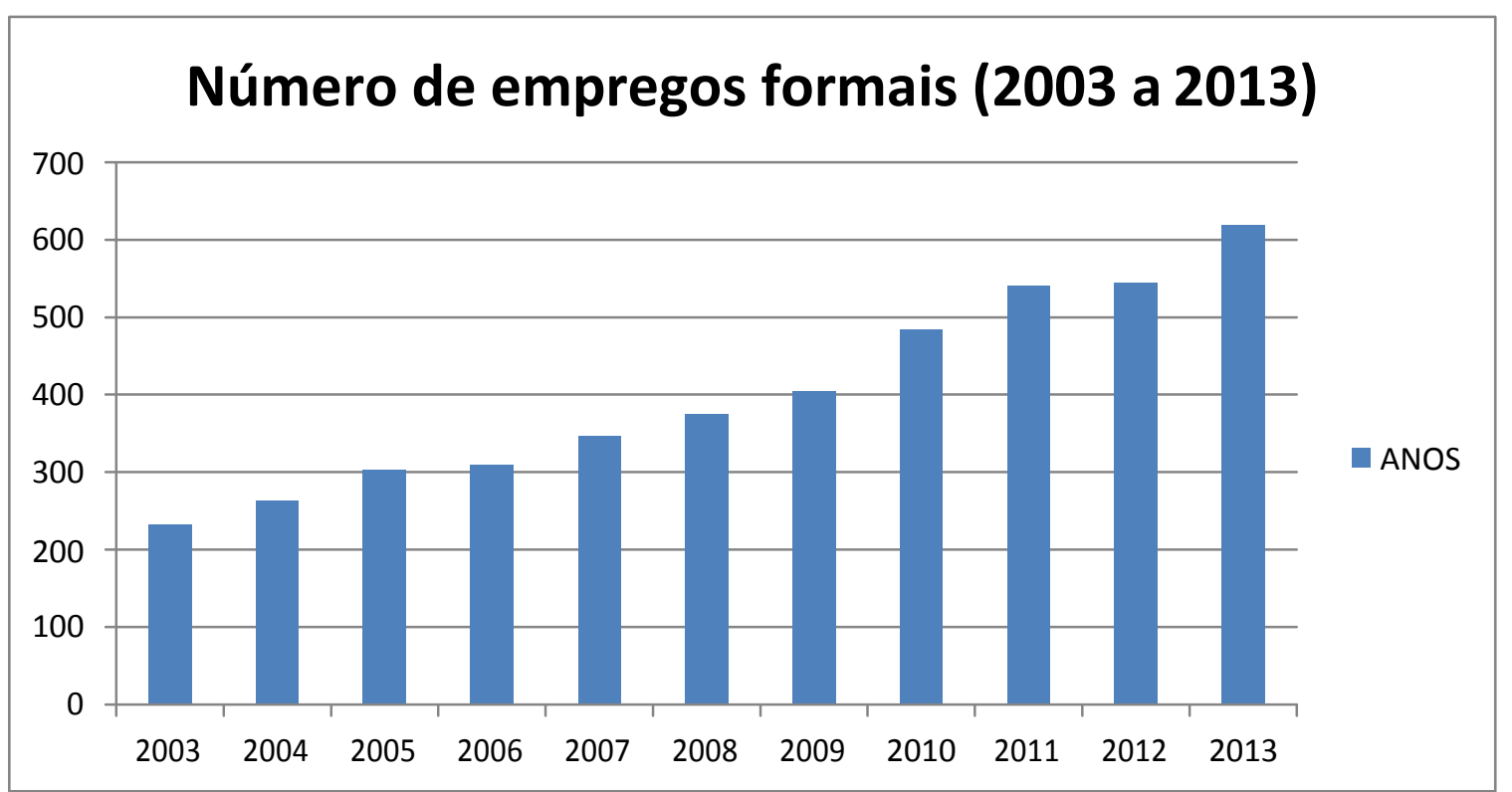

Fonte: RAIS/TEM. Elaborado pela autora.

\footnotetext{
${ }^{62}$ Para uma apreciação mais detalhada dos dados analisados, consultar os anexos desta dissertação.
} 
Esse aumento demonstra que os empresários têm ao longo do tempo registrado seus trabalhadores dessa forma garantindo os direitos trabalhistas e proteção social.

Contudo, cruzando os dados dos empregos formais no turismo com as empresas formalizadas do turismo que somam 330 , e considerando que a média de trabalhadores (conforme depreendido nas entrevistas) é de sete trabalhadores por empreendimento, foi possível revelar que a informalidade é expressiva no município, os empregos informais podem superar em até quase quatro vezes mais os empregos formais.

Em relação ás Atividades Características do Turismo (ACTs), o panorama do período analisado apresentou que a maioria dos trabalhadores estiveram alocados na ACT Alojamento. Entretanto, quando comparadas ACT Alojamento e ACT Alimentação, ao longo dos anos, o número de trabalhadores alocados na ACT Alimentação, apresentou aumento significativo, enquanto que os trabalhadores da ACT Alojamento diminuiu.

Embora essas duas ACTs (Alojamento e Alimentação) sejam responsáveis pela maioria dos empregos gerados em todos os anos, cabe ressaltar que as ACTs de "Cultura e Lazer", "Transportes", "Agência de Viagens" e "Auxiliares do Transporte", veem ao longo dos anos, sobretudo a partir de 2008, participando timidamente - da economia do turismo.

Se por um aspecto esse fenômeno propicia diversidade na oferta de ocupações no mercado de trabalho no turismo, por outro aspecto essa diversidade não é sinônimo de aumento do número de empregos, pois essas atividades não tem capacidade de gerar muitos empregos, quando considerada a realidade do turismo de Pirenópolis, em que a demanda de turistas é majoritariamente regional e não nacional ou internacional, sendo os acessos aos atrativos relativamente fáceis pela sinalização e infraestrutura acessível, o que torna esses serviços (como guia, agenciamento, transporte, entre outros) não necessariamente indispensáveis como ocorre em outras destinações turísticas. 
GRÁFICO 2 - Faixa salarial dos empregos formais considerando todas as Atividades Características do Turismo (2003 a 2013).

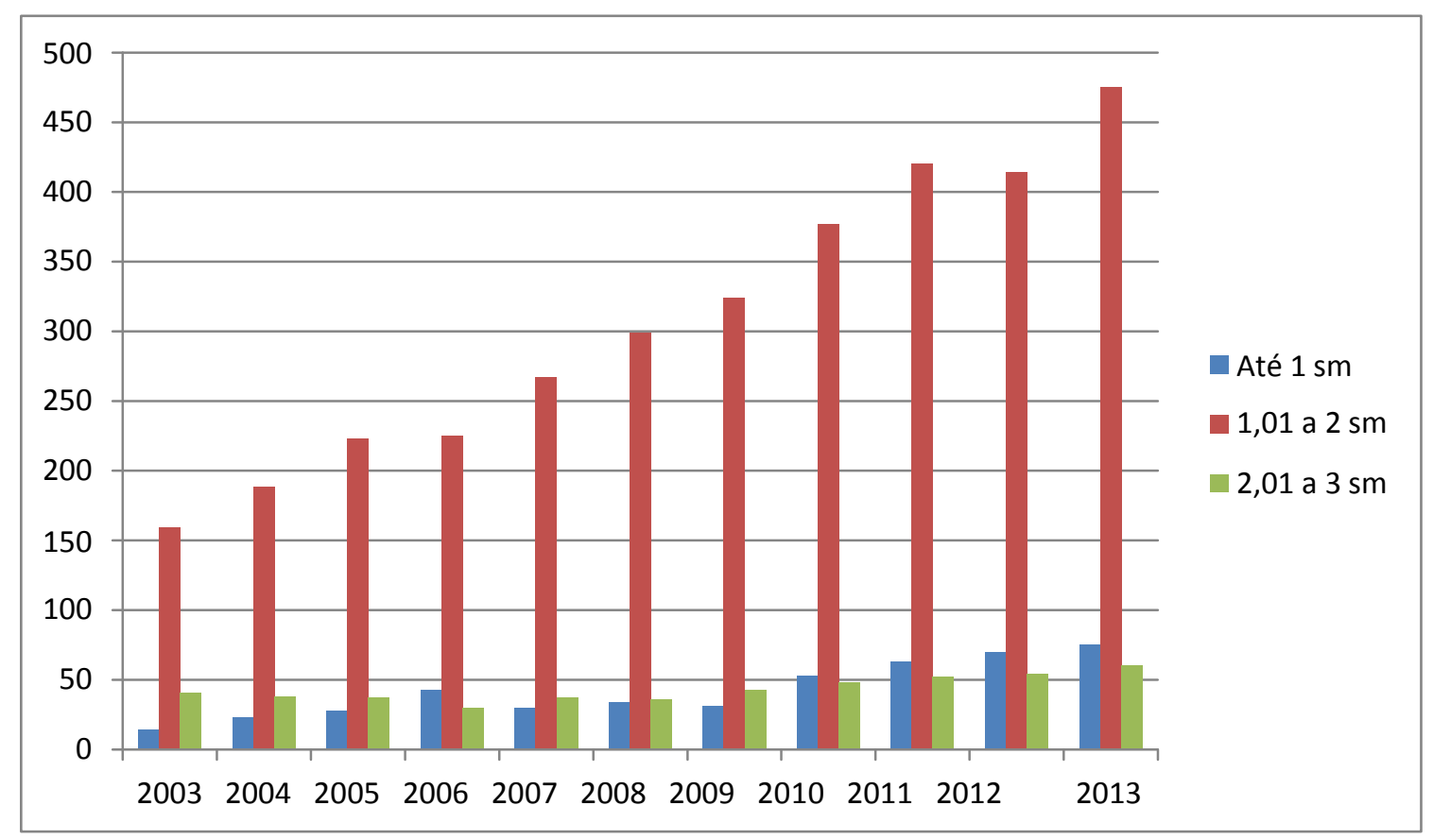

Fonte: RAIS/MTE. Elaborado pela autora.

Analisando os dados sobre a faixa salarial dos trabalhadores das ACTs ao longo do período, pôde se verificar que a maioria dos trabalhadores tem renda entre 1,01 e 2 salários mínimos, contudo cabe ressaltar que houve um aumento no número de trabalhadores que fizeram parte da faixa salarial de ganhos até 1 salário mínimo, 12\% dos trabalhadores compunham essa faixa de ganhos em 2013.

As entrevistas vieram a confirmar essa realidade, dentre todos os trabalhadores entrevistados considerando as ocupações de camareira, recepcionista, cozinheiro e auxiliar de serviços gerais, nem os formados em turismo e os que têm cursos de qualificação revelaram ter ganhos acima de 2 salários mínimos, mesmo quando consideradas as comissões e gratificações.

Um dado relevante em termos salariais ao longo do decênio, que cabe ser considerado, é que somente a partir de 2007 que os trabalhadores das ACTs Cultura e Lazer, e, Alimentação passaram a ter ganhos acima de 2 salários mínimos mensais, (embora tenham sido somente 2 trabalhadores), pois até então somente trabalhadores da ACT Alojamento, obtinham ganhos acima de 2 salários mínimos mensais. 
Com os dados pôde ser verificado que a classe trabalhadora do Turismo de Pirenópolis é composta por majoritariamente mulheres com ganhos de até 2 salários mínimos mensais, vale ressaltar que ocorreu no período um aumento gradativo de mulheres que se encontraram nesta faixa, e analisando o comportamento dos dados a tendência é de que esse panorama continue.

Somente os homens (que são a minoria dos trabalhadores totais), tiveram ganhos acima de 3 salários mínimos mensais, o que evidencia a exemplo da dinâmica global do mercado de trabalho, que as mulheres recebem menos do que os homens, entretanto, pôde se verificar que ao longo dos anos houve um decréscimo nas faixas salariais com ganhos acima de 3 salários mínimos.

Os dados levantados sobre a faixa etária dos trabalhadores evidencia um perfil majoritariamente formado por adultos na faixa de 30 a 39 anos, em sua maioria mulheres.

Cabe ressaltar que no período houve um decréscimo de trabalhadores jovens, em contrapartida, um aumento de adultos, principalmente dos que se encontram na faixa de 40 a 49 anos.

As entrevistas realizadas com os empresários evidenciaram que há em certa medida um desinteresse dos jovens em trabalhar com o turismo.

\footnotetext{
Hoje pra mim no restaurante o que é mais difícil é a mão de obra porque assim pessoal não quer um compromisso são poucos que "quer" só quem é pai de família mesmo porque a maioria dos jovens.... chega final de semana que é a época que a gente mais precisa no restaurante eles querem tá de folga "que curti" por isso que a gente trabalha mais com pessoal da família.(relato da entrevista com empresário da alimentação, 2015).

Por exemplo tem um menino que trabalha aqui com a gente filho de uma funcionária está terminando o segundo grau pergunta se ele pensa em continuar a estudar pergunta se ele tem anseio de algo mais? e o menino adora gastronomia $O$ menino cozinha que é uma maravilha porque não vai fazer gastronomia que a faculdade é aqui do lado? "não... não vou, quero fazer psicologia". (relato da entrevista com empresário de atrativo turístico e alimentação, 2015).
}

No caso de Pirenópolis em certa medida esse desinteresse dos jovens pode ser explicado em partes pela questão cultural, mas há também uma parcela da juventude que por não querer trabalhar no turismo em que as atividades profissionais e as possibilidades de carreira e ganho são restritas acabam por sair da cidade, afinal "não é do gosto de todos trabalhar a serviço dos outros e passar por seres de segunda classe" (KRIPPENDORF, 2009). 
Dos profissionais formados na primeira turma ${ }^{63}$ do curso de tecnologia em turismo da universidade local, apenas três permaneceram trabalhando com turismo, os demais alguns inclusive já realizaram uma segunda faculdade e atuam em outras áreas distintas do turismo, alegando que os ganhos são baixos e queixaram-se das jornadas de trabalho. Muitos desses jovens não se sentem atendidos em seus anseios profissionais ${ }^{64}$, pois além da renda deles não ter sido alterada após 0 término do curso, se sentem desvalorizados frente aos demais trabalhadores que não tem qualificação, já que a remuneração deles é a mesma.

acredito que precisa acontecer de fato nesta cidade é os proprietários dos meios de hospedagem, do setor de alimentação começarem a contratar mão de obra especializada e valorizar essa mão de obra porque tem uma "galerona" formada em turismo, tem uma "galera" formada em gastronomia e que não está se sentindo valorizada. Porque aqui é assim, a pessoa entra pra trabalhar mas vai ganhar a mesma coisa que a outra pessoa sem qualificação, e isso desestimula a pessoa, porque se eu estudei eu tenho mais a acrescentar do que quem não estudou, o meu atendimento será melhor do que o de quem não estudou, então o que eu acho é isso falta de valorização por parte dos empreendedores.(relato da entrevista com trabalhadora de meio de hospedagem e tecnóloga em turismo, 2015).

Quanto ao tempo que esses trabalhadores permanecem em seus empregos, pode se depreender que embora os trabalhadores que ficaram em seus empregos de 1 a 2 anos tenham sido a maioria dentre o total de trabalhadores, um dado relevante foi o crescimento significativo dos trabalhadores que ficaram em seus empregos até 3 meses. Conforme verificado nas entrevistas, alguns empresários queixaram-se da rotatividade dos trabalhadores nos empregos.

assim a rotatividade de serviços em Pirenópolis tem muito.... oportunidade tem, de garçom, de cozinheira, mas ninguém se capacita então quer dizer a oportunidade de trabalho existe para todos, a coisa vem crescendo, quem quer está trabalhando, mas isto não quer dizer que o cara vai se capacitar para trabalhar; ele vai apenas ir trabalhar o que ocorre muitas vezes é que ele vem , se capacita e "dali" 3 meses ele vai para outro lugar... e vai girar então há uma rotatividade... aqui a gente não tem, mas isto é geral é visível em Pirenópolis, eu tenho amigos que tem restaurante na "rua do lazer" que reclamam. (relato da entrevista com empresária de atrativo turístico e alimentação, 2015).

\footnotetext{
${ }^{63}$ A autora da dissertação foi professora da primeira turma de alunos do curso de tecnologia em gestão do turismo da universidade local e realizou uma pesquisa com os ex-alunos que revelaram tais informações.

${ }^{64}$ Conforme depreendido da análise da monografia de conclusão do curso de tecnologia em gestão do turismo da aluna Alessandra dos Santo Dias intitulada "O mercado turístico em Pirenópolis e o curso de tecnologia em gestão de turismo", UEG, 2014.
} 
Um dos problemas da rotatividade aqui também é porque as pessoas tratam mal os trabalhadores, você pode ver que a maioria que tem problema com rotatividade de trabalhador é por conta tratamento.(relato da entrevista com trabalhadora de meio de hospedagem, 2015).

Os dados revelaram que houve um aumento no grau de escolaridade dos trabalhadores empregados nas ACTs, essa dinâmica deveu se, sobretudo a um aumento no Ensino Médio completo, composto por $58 \%$ de mulheres. Contudo houve um aumento de $3 \%$ no Ensino Superior completo, mas não há como ter conhecimento se a formação desses trabalhadores é na área do turismo e/ou áreas correlatas.

Em relação ás condições de trabalho e o respeito aos direitos trabalhistas nas atividades relacionadas ao turismo, às entrevistas revelaram que os empreendedores em certa medida os respeitam, a maioria dos empresários relataram ter quase todos os seus funcionários registrados na carteira de trabalho, portanto assalariados, informação que foi confirmada junto aos trabalhadores. Os trabalhadores recebem entre 1 e 2 salários mínimos, e alguns recebem gratificações como comissão sobre vendas, mas o percentual é variável, alguns recebem $4 \%$, outros apenas $1 \%$. No entanto, conforme depreendido dos dados do MTE a formalidade não é expressiva.

Os trabalhadores relataram ainda que seus "patrões" quase não Ihes solicitam horas extras e quando as solicitam é pago em dinheiro junto com o salário, pagam salário família para aquelas mulheres que tem crianças pequenas. As folgas são respeitadas sendo uma por semana, e um domingo no mês, os relatos evidenciaram que o período de férias também no geral é respeitado. Na maioria dos casos relataram que os empreendedores fornecem alimentação, almoço no caso dos que trabalham oito horas e lanche nos demais casos, mas a maioria não paga vale transporte e nenhum oferece assistência médica a seus trabalhadores.

A fala dos trabalhadores denota que eles não possuem conhecimento sobre quais são seus direitos. Nenhuns daqueles que não recebem o valor do transporte demonstraram saber que lhes é de direito.

Assistência médica a gente tem por exemplo se a gente passar mal, sempre tem um que corre pra levar pra um hospital se precisar, agora transporte não, a cidade é tão pequena que nem tem transporte daí uso a minha bicicleta mesmo. (relato da entrevista com trabalhador da alimentação, 2015).

$\mathrm{Na}$ verdade o que a gente recebe de benefício é a alimentação, mas não recebo nenhum valor referente a vale transporte não, mas assim o fato de 
se morar em uma cidade pequena eu acho que transporte não é necessário porque eu moro aqui no bairro mesmo.(relato da entrevista com trabalhadora de meio de hospedagem, 2015).

Não recebemos nem alimentação, nem assistência médica e nem vale transporte não, acho que aqui na cidade poucas empresas "dão" tais benefícios por ser uma cidade bem pequena e não ter transporte coletivo, e termos horário de almoço.(relato da entrevista com trabalhadora de agência de viagem, 2015).

Como benefício por eu ter uma criança, eu recebo uma "bolsa família "que vem no meu pagamento, no meu salário...não sei muito bem, mas que acho que é o governo que dá.(relato da entrevista com trabalhadora de meio de hospedagem, 2015).

Essa questão sobre os trabalhadores não conhecerem bem seus direitos pôde ser confirmada pela fala de uma empresária.

o que a gente percebe é assim, que a gente recebe muitos funcionários que nunca tiveram seus direitos trabalhistas respeitados e parece que "ali" onde eles estavam, eles tinham mais respeito pelo trabalho... temor... algum compromisso, as vezes as pessoas ficaram anos sem nunca assinar a carteira, e daí quando a pessoa chega num lugar aonde ela é respeitada, nem ela sabe se comportar...assim em relação a isso, a sentir se é respeitado ou se não, as vezes você tem que dar mesmo uma "aula" de direito trabalhista para que a pessoa compreenda né, o direito que ela tem , pra mostrar que ela é respeitada, que aqui é um local diferente né, para mostrar que o que eu tô fazendo é respeitar o direito dela né. (relato da entrevista com empresária de meio de hospedagem, 2015).

Um dado relevante foi que a maioria dos trabalhadores (á exceção de um) de meios de hospedagem faz hora ininterrupta, trabalhando seis horas direto e os empresários pagam a entre jornada, que é o valor da hora de almoço, prática permitida por lei, os trabalhadores que fazem essa jornada diferenciada relataram que as empresas oferecem lanche. Ao indagarmos o porquê dessa prática os trabalhadores informaram que optaram por tal forma por "terem mais tempo" para realizar as tarefas domésticas no caso das mulheres e por que se forem para casa o tempo que gastariam para "ir e voltar" não compensaria. Como a cidade não tem transporte coletivo público, talvez essa opção deva-se a este fato.

No entanto, não há funções muito definidas, os trabalhadores relataram que fazem de "tudo um pouco", especialmente os que trabalham em empreendimentos de pequeno porte.

Eu trabalhei em uma pousada durante um tempo, e eu fui "indo" e não aguentei porque eu fazia serviços desde recepção até o serviço de quarto, eu estendia a cama, ajudava a limpar os quartos, a manutenção na área da piscina, limpeza, reservas, ajudava no café da manhã...também não tinha treinamento, então eu acho que é muito explorador . (relato da entrevista com trabalhadora de meio de hospedagem, 2015). 
Contudo essas condições foram evidenciadas com a maioria dos trabalhadores de meios de hospedagem, o que não ocorreu com trabalhadores da alimentação.

No geral esses trabalhadores em sua maioria trabalham em regime de diarista, sem registro em carteira, portanto sem proteção social. Alguns alegaram que recebem gratificações quando o "movimento é bom", mas que são estabelecidas a gosto do patrão.

se eu vejo que o meu final de semana foi bom e os funcionários trabalharam muito, eu dou uma bonificação se a coisa foi boa e merecida, aí eu distribuo por igual, eu dou a mesma quantia de bonificação para todo mundo.(relato da entrevista com empresário da alimentação, 2015).

assim quando é bom pra eles, têm que ser bom pra gente também então quando o movimento é bom a gente sempre ganha uma quantia a mais vamos dizer assim a minha diária é setenta reais eles me pagam cem reais no dia que foi bom o movimento.(relato da entrevista com trabalhadora da alimentação, 2015).

Então essa falta de interesse é geral só alguns que são diferentes, daí você não consegue assinar a carteira, você não consegue dar continuidade, você não consegue ajudar, porque a pessoa não tem vontade... igual, cursos 0 que mais tem é curso... Falta de interesse mesmo, de vontade... porque tem curso que até paga hoje pra você fazer o curso ...hoje tem, todo mundo sabe que tem, a gente chega direto falando de curso...aí vai indo você para de falar lógico, você sabe que a pessoa não vai fazer. Daí você viu a menina falar tem 10 anos que ela trabalha aqui de diarista, mas não quer fazer curso, não quer capacitar.(relato da entrevista com empresário de atrativo turístico e alimentação, 2015).

As jornadas são longas e muitas vezes não pagas, as pessoas trabalham

geralmente aos finais de semana, período em que a cidade apresenta um fluxo

turístico mais evidente e muitos fazem dupla jornada, trabalham durante a semana

em outra atividade e aos finais de semana com turismo.

Eu trabalho faz pouco tempo agora na pousada mas minha mãe trabalha de cozinheira então no período diurno ela trabalha na casa de família e a noite ela trabalha no restaurante de cozinheira e ela trabalha sem carteira assinada de domingo a domingo, é "diretão". Pessoas que têm carteira assinada lá onde a minha mãe trabalha no restaurante é alguma pessoa que fica na área da frente do restaurante, porque os garçons não tem carteira assinada por que tem rotatividade e os donos também nunca incentivam em falar "o fulano eu vou assinar sua carteira", lá o diarista recebe quando o dono quer pagar que é uma coisa horrível, só para minha mãe eles estão devendo quase 4 mil reais de coisas atrasadas, esses tempos atrás eles estavam tirando a porcentagem dos garçons escondido, tirando por fora comissão do pessoal da cozinha...eu já trabalhei lá na "rua do lazer" inclusive neste restaurante também, e é muito complicado, você pode perceber que o mesmo garçom que trabalha na "rua do lazer" pela manhã ele trabalha até de madrugada, eu sei por que eu já 
entrei lá 8 horas da manhã e sai as 3 horas da manhã do outro dia então é difícil.(relato da entrevista com trabalhadora de meio de hospedagem, 2015).

Eu trabalho só sábados e domingos e os feriados já nas férias é direto, folga só uma vez na semana nas férias... tem problema só em relação a horário de almoço por causa da correria. Durante a semana eu tenho outro trabalho, eu passo roupa, faço faxina, e venho pra cá no final de semana também que eu venho para cá trabalhar de diarista na cozinha.(relato da entrevista com trabalhadora de alimentação, 2015).

Por exemplo quando o feriado foi bom a gente dá um uma gorjeta "pro" pessoal, "pra" equipe inteira ou um dia de folga pra ele descansar... Tipo quando é uma férias que fica 30 dias sem folga então a gente fecha um dia a gente paga a hora que passou a mais. (relato da entrevista com empresário da alimentação, 2015).

Esse panorama denota que existe uma precarização do trabalho nas ACTs, cabe considerar que essa é uma tendência mundial, especialmente no setor de serviços (HARVEY,2012; STANDING, 2013).

Quando indagados sobre qual seria a importância do turismo para Pirenópolis, todos revelaram ser a "oportunidade de trabalho", ou por ser "a principal renda" no município, para a "economia da cidade".

Alguns que são autóctones chegaram a atribuir a responsabilidade ao turismo pelo "desenvolvimento da cidade", há ainda uma mistura de sentimentos em relação ao turismo, embora reconheçam que tem oportunidade de trabalho, mas também que há mazelas, muitos ainda assim acreditam ser melhor do que as condições anteriores. Há um sentimento de "orgulho" em relação à cidade.

O turismo contribuiu para a cidade inteirinha, "se" pode dizer que a maioria agora vive do turismo...o povo faz tapete, joia, até artesanato mesmo de pedra o povo tá fazendo. De certa forma antes Pirenópolis era procurada por que era calma, hoje em dia você pode ver que tem muita gente reclamando porque tá muito movimentado sabe, mas a qualidade de vida é muito boa, porque você pode ver que é mais final de semana e feriado, durante a semana é pacato, na minha opinião não afeta muito... muito pelo contrário porque ao mesmo tempo que você tá tranquilo no final de semana você tá agitado você tem as duas coisas a calmaria e depois a agitação então vejo com bons olhos espero que cresça mais porque Pirenópolis acho que é assim mundialmente conhecido sabe tanto é que direto tá cheio de gringo aqui porque a região aqui nossa maravilhosa antes do restaurante a gente fazia muito passeio a cavalo em noite de lua cheia, a gente saia pra passear. (relato da entrevista com trabalhador da alimentação, 2015).

O turismo é fundamental, uma cidade como a nossa que tem quase 288 anos e que até então não desenvolveu economicamente, não oferecia oportunidade de trabalho para a população e que a sua principal fonte de renda era a destruição do meio ambiente através da extração de pedras, o turismo veio como uma oportunidade de crescimento sustentável, onde as pessoas começaram a ter consciência que a preservação do meio ambiente, do patrimônio histórico e das tradições culturais eram 
fundamentais para que esta atividade crescesse e trouxesse renda para a cidade, e nós nativos de Pirenópolis não mais precisávamos sair da cidade em busca de trabalho e de lazer, que era o que acontecia até então. Hoje em dia muitos cidadãos locais tem oportunidade de trabalho, montam seu próprio negócio, estudam na universidade local. Apesar de haver muita desvalorização da mão de obra por parte de empresários do setor turístico e principalmente pelo custo alto de vida devido a valorização da cidade por conta do turismo, e vários outros pontos negativos que a atividade trouxe para a cidade. Mas ainda assim, o turismo foi a melhor alternativa de desenvolvimento econômico para o nosso município, muito melhor que qualquer outra atividade que cidades pequenas tem pelo país. Eu como filha de Pirenópolis tenho o maior orgulho de trabalhar com turismo, e passar todo meu amor pela minha terra para quem vem visitá-la, e conscientizar a todos sobre a importância da valorização da nossa cidade. (relato da entrevista com trabalhadora de agência, 2015).

Esta autoestima elevada das pessoas da comunidade, com o reconhecimento de sua singularidade, o valor de sua cultura, de seus recursos naturais e de suas tradições, é um dos primeiros sentimentos que ocorrem no início do desenvolvimento turístico nas localidades, é o sentimento do "deslumbre", onde tudo parece ser "cor-de-rosa" como nos dizia Krippendorf (2009). Não há nesse momento muito a contestação por parte dos autóctones sobre os custos sociais e ambientais sobre a forma como o turismo é desenvolvido.

Quando indagados sobre a alteração em suas vidas a partir do momento em que passaram a trabalhar com o turismo as respostas enfatizaram a possibilidade de "contato com outras pessoas" alguns ainda revelaram a renda, outros a "complementação de renda" e a alternativa de trabalho, contudo á exceção de um trabalhador, os demais relataram de forma velada e outros de forma declarada a mudança no que tange ao comprometimento de seu tempo livre para a prática de lazer.

Alguns trabalhadores e empresários autóctones quando entrevistados revelaram as alterações que houve na cidade após a instauração do turismo no que tange ao mundo do trabalho e as relações capital/trabalho.

eu vejo que não mudou muito a condição de trabalho das pessoas que trabalhavam na pedreira e que agora trabalham no turismo... Eu acho que ficou a mesma coisa por que como sempre foi ruim...porque na pedreira a pessoa trabalha longe tem que ficar o dia inteiro embaixo do sol, não tem quase material de segurança, nada disso, mas assim para as pessoas que têm estudo, tem um certo conhecimento, eu diria que o turismo as condições de trabalho "melhorou" em relação à pedreira, mais para algumas pessoas que trabalham em um lugar "legal", que tem uma função, um cargo bom, daí eu creio que melhorou sim, agora "pra" pessoa que não tem um certo estudo, não entende muito bem, ou que trabalha nessa área mas em uma área mais "braçal" eu diria que não. Então quem tem estudo se dá bem, ganha um pouco melhor, agora quem não tem se lasca. (relato da entrevista com trabalhadora de meio de hospedagem, 2015). 
Com o turismo teve mudança, antigamente a gente antes era tipo um "coronel e o empregado", porque você não tinha leis trabalhistas, você não tinha apoio, você não tinha nada. Com o turismo é que foi vindo, porque a pessoa teve acesso as leis de trabalho, teve acesso a um melhor salário, porque o trabalho na pedreira é tipo um trabalho escravo, você ganha pouco, tem que produzir muito e quem na verdade ganha é o dono da pedreira, porque o trabalhador mesmo não ganha.

Mas por exemplo hoje quem trabalha na pedreira mudou, conforme o turismo foi "vindo" e o trabalho começou a ficar escasso na pedreira, porque aumentou restaurante, aumentou pousada e o pessoal da pedreira migrou para o restaurante e pousada, e daí o que ele [dono da pedreira] tem que fazer? melhorar lá na pedreira "pra" poder manter os funcionários aí ele teve que adequar à lei, hora de trabalho, equipamento de segurança, então o turismo fez foi melhorar. (relato da entrevista com empresário de alimentação, 2015).

Diante do panorama exposto sobre as relações de capital e trabalho e sua influência na caracterização do processo de desenvolvimento do turismo de Pirenópolis, foi averiguado que houve uma mudança mediante as relações estabelecidas diante da atividade econômica de maior pujança antes da instauração do turismo, que é a extração e beneficiamento de pedra quartzito. O turismo em certa medida serviu para estabelecer alguns parâmetros um pouco mais profissionais, de certa maneira propiciou a prática do respeito aos direitos trabalhistas. Ampliou o mercado de trabalho e oportunizou de certa forma o empreendedorismo familiar.

Contudo, os direitos trabalhistas não são respeitados em sua totalidade, a informalidade é expressiva, portanto não há proteção social para a maioria dos trabalhadores do turismo e não deu conta de resolver os antagonismos de classe.

A relação "coronelista" de outrora estabelecida entre o coronel possuidor de seus escravos, portanto podendo fazer o que quisesse destes, fora apenas substituída e amenizada pela relação de patronato, empresários do turismo e trabalhadores dos serviços, em que em nome do respeito a alguns direitos trabalhistas pode se tratar seus trabalhadores do modo que bem lhes convier.

O desenvolvimento do turismo de Pirenópolis não passou de crescimento, portando não está sendo um novo instrumento de transformação das práticas socioeconômicas propiciador de um desenvolvimento sustentável e includente, com promoção da cidadania, de redução das desigualdades sociais, do trabalho digno e decente.

Da forma como vem sendo conduzido tanto pela gestão pública quanto pela iniciativa privada e até em certa medida pela comunidade local, a exemplo da 
especulação imobiliária, está servindo meramente para a reprodução de capital e não desenvolvimento em si.

\section{CONSIDERAÇÕES FINAIS}

As frequentes crises do modelo que a humanidade optou por seguir tem se mostrado incompatível com os anseios por construir sociedades mais justas e solidárias. A sociedade moderna fruto do processo de industrialização padronizou não apenas os seus produtos mas também suas relações pessoais, seu habitat e as diversas práticas socioculturais.

De acordo com a lógica do capitalismo, o turismo foi concebido como a "indústria sem chaminés" e passa a ser encarado como propiciador do desenvolvimento, via geração de emprego e renda e inclusão social. Diante de tal concepção, tinha-se no turismo a possibilidade de desenvolver economicamente um país, região ou cidade à luz do capitalismo industrial, sem os impactos ao meio ambiente natural. $\mathrm{Na}$ esteira desta concepção o processo de ressignificação e requalificação das cidades se faz presente, as denominadas "cidades-patrimônio", estimulam ainda mais o movimento de segregação espacial/material e social.

A dinâmica que se estabelece nas cidades-patrimônio assim como em Pirenópolis, permeadas por posicionamentos "empreendedores", são atreladas a planejamentos estratégicos, fragmentados e fragmentários da totalidade em diferentes escalas., desconsiderando o território com todas as suas tessituras, relações e processos contraditórios, forças e resistências. Denominados estratégicos, como a própria nomenclatura evidencia, atendem a interesses de certos grupos da sociedade políticos e/ou econômicos. Raramente esses planejamentos são elaborados em conjunto com aqueles que são destinatários de suas ações: os cidadãos.

O desenvolvimento do Turismo enquanto meramente "atividade econômica", em Pirenópolis, ocorreu especialmente devido a investimentos de capital, em princípio por empreendedores locais e oriundos especialmente de Brasília e Goiânia, sobretudo com o auxílio do Estado, na construção e melhoria de infraestrutura e estabelecimento de políticas públicas com interesses difusos.

Essa dinâmica instituiu uma ampliação das perspectivas de emprego, em especial para aqueles os quais o mercado de trabalho não "exige" qualificação 
técnica mais apurada, como as atividades de limpeza e serviços gerais, de portaria, dentre outras.

Cabe salientar que em razão de não ser uma atividade produtiva ${ }^{65}$ como a indústria ou a agricultura, geralmente o turismo é classificado - sob o paradigma funcionalista - no setor de serviços como nos atenta Moesch (2000b).

Essas novas relações sociais de produção geralmente exercem mudanças significativas nas localidades, seguindo a lógica e a dinâmica do sistema mundo de "acumulação flexível".

A sazonalidade do turismo, que se reflete no número de postos de trabalho gerados, traz implicações no que diz respeito "à regularidade dos ganhos, tendo esta, maior impacto justamente sobre os cargos mais modestos".(Beni, 2006, p.52), o que em outro movimento, por vezes, provoca também um desestímulo do trabalhador em empenhar-se e comprometer-se com a atividade que exerce, uma vez que ele não tem garantias nem em termos de ganhos, de direitos trabalhistas e nem de incentivo ao estudo formal ou à qualificação por parte dos empregadores.

A qualificação que é exigida pelos empreendedores turísticos em Pirenópolis não é compatível com a qualificação das pessoas da comunidade, o que implica na migração de pessoas de outros lugares para atender a essa demanda do mercado, principalmente nos cargos de gerência que exigem uma maior qualificação, restando aos trabalhadores locais, as atividades mais simples, como limpeza e arrumação (camareiras), serviços gerais, dentre outras.

Em Pirenópolis, o aumento da participação das mulheres no mercado de trabalho no turismo tornou-se expressivo. Além de terem condições desiguais frente á força de trabalho masculina - recebendo salários inferiores, por vezes trabalhando em jornadas mais prolongadas, realizando multitarefas.

Cabe salientar que as mulheres fazem parte não só do processo de produção mas também de reprodução do capital, uma vez que elas desempenham duplo

\footnotetext{
${ }^{65}$ Embora não se reconheça o turismo como uma atividade produtiva, conforme demostrado ao longo da dissertação, entende-se que o trabalho nas atividades turísticas é produtivo pois de acordo com Marx (2000) "é produtivo o trabalhador que produz mais-valia para o capitalista, servindo assim à auto expansão do capital [...]: um mestre-escola é um trabalhador produtivo quando trabalha não só para desenvolver a mente das crianças, mas também para enriquecer o dono da escola. Que este invista seu capital numa fábrica de ensinar, em vez de numa de fazer salsicha, em nada modifica a situação. O conceito de trabalho produtivo não compreende apenas uma relação entre atividade e efeito útil, entre trabalhador e produto do trabalho, mas também uma relação de produção especificamente social, de origem histórica [capitalista], que faz do trabalhador o instrumento direto de criar mais-valia" (MARX, 2000, p.578).
} 
papel no sistema capitalista: enquanto produtora (trabalhando por horas de forma assalariada ou não) e enquanto reprodutora (executando os trabalhos domésticos em sua vida privada), "em que se criam as condições indispensáveis para a reprodução da força de trabalho de seus maridos, filhos (as) e de si própria". (ANTUNES, 2000, p.108).

O processo contraditório da relação capital e trabalho, ajuda a explicar em partes, a razão de diversos municípios que experimentaram taxas consideráveis de crescimento econômico com a instauração do turismo, não necessariamente tiveram desenvolvimento.

Ao mesmo tempo em que geraram mais empregos, as condições existenciais da comunidade receptora, considerando os aspectos, sociais, ambientais, culturais, político-institucionais e econômicos, por vezes se encontra até mais degradada do que antes.

Neste sentido Beni (1999) faz um alerta para que "o compromisso com o trabalho e a ocupação nas atividades relacionadas ao turismo deve resultar em um modelo includente e estável' (BENI, 1999, p.105).

Crucial se faz a investigação sobre as condições existenciais daqueles que são produtores e reprodutores do turismo - seus trabalhadores, homens e mulheres, sobretudo para além das condições materiais, mas também subjetivas.

O estranhamento é um aspecto do trabalho no turismo que merece ser investigado, já que esses trabalhadores (produtores) laboram no tempo de lazer dos turistas (consumidores). Mesmo sendo partícipes da reprodução do capital, os trabalhadores não tem condições de usufruir desta, não só pelo fato de não se apropriarem do produto de seu trabalho em sua totalidade - já que ficam somente com a parte monetária que lhes cabe, na forma de diárias, gorjetas, comissões, salários - mas também pelo fato de não terem tempo disponível para usufruir seu lazer, já que se veem expropriados dele, trabalhando em jornadas prolongadas, especialmente em feriados, férias, finais de semana, a exemplo do que depreendemos da realidade em Pirenópolis. Cabe ressaltar, que o turismo se converteu em um direito, de todos os cidadãos, de acordo com a carta magna de 1988, não importando a classe social ou sociedade a que faça parte.

Esse compromisso poderá ser possibilitador de um desenvolvimento pelo Turismo, somente se houver um pacto entre os partícipes: poder público e suas políticas públicas, empreendedores, e trabalhadores/cidadãos. 
Não se trata de negar a importância do aspecto econômico que tem 0 Turismo, mas sim de relativizar esse aspecto em face aos demais aspectos concernentes a ele. Da mesma forma que não se trata de negar as contribuições das concepções de cunho econômico, mas sim, de não absolutizá-las, uma vez que o próprio processo de construção do conhecimento é dinâmico e complexo.

As políticas públicas de turismo seguem a mesma lógica mercadológica, embora em tese, proponham o processo de elaboração e gestão participativa, trazendo a perspectiva da inclusão social, na prática revelam ser construídas e direcionadas para atender os anseios sobretudo do mercado e do equilíbrio no balanço de pagamentos da "conta turismo".

No entanto, a questão não é simplesmente negar o planejamento, mas sim concebê-lo enquanto um instrumento a ser construído de forma democrática e participativa para orientar a ordenação da ocupação do espaço, considerando a sua totalidade, de forma que possibilite a equidade social, que propicie 0 desenvolvimento humano e criativo da comunidade, garantindo ao mesmo tempo a preservação da cultura e do ambiente natural e construído. Portanto, o sujeito deve ser o centro do planejamento, e não os setores econômicos.

A construção de um turismo em bases sustentáveis, implica na participação de fato, não só representativa, daqueles que o desenvolvem, não só "produtores", mas destinatários desta "produção" (trabalhadores, empresas, ONGs, a comunidade como um todo das localidades), nas discussões e na edificação do desenvolvimento do turismo. Os sujeitos partícipes deste processo, especialmente os trabalhadores devem ser encarados como ativos e não só lembrados como mão de obra barata e desqualificada.

A participação nesses processos pode não ser a garantia do atendimento de todos os anseios, no entanto, o exercício democrático pode ser o embrião de uma organização da comunidade, para que esta pleiteie seus direitos de cidadania.

Tão relevante quanto a participação se faz a fiscalização e a cobrança por parte dos cidadãos à todos os envolvidos (inclusive eles próprios), no cumprimento dos projetos e as ações que forem pactuadas.

Embora, deva se levar em consideração que a gestão do território de forma participativa ainda encontra dificuldades - uma vez que o processo democrático no país é recente, e a cultura da participação ainda esteja por se consolidar - este não deve ser um entrave, deve ser encarado como um desafio a ser superado e a gestão 
pública, sobretudo a municipal, tem um relevante papel a desempenhar neste sentido.

A adoção do turismo como elemento constituinte de uma sociedade deve iniciar pelo reconhecimento dos benefícios e dos riscos que podem ocorrer. Um desses riscos é a exploração que a mídia faz do turismo, retratando quase que exclusivamente as situações de viagens, de festividades e grandes eventos, como depreendido da realidade em Pirenópolis. Desse modo a tomada de consciência do turismo pelo senso comum sofre considerável influência dos meios de comunicação de massa.

As práticas turísticas baseiam-se em um "fazer" e não no "saber-fazer". Os sujeitos reproduzem as práticas, mas diante de poucos conhecimentos e informações sobre o fenômeno turístico, não compreendendo o significado de seus fazeres.

Os riscos mais reconhecidos advindos do turismo são as degradações ambientais e culturais, que podem ser minimizadas a partir da inclusão dos sujeitos locais, considerando seus valores locais, suas experiências, seus interesses e expectativas, criando áreas de interesse, áreas de preservação, limites e possibilidades para o turismo.

Pensar o turismo enquanto fenômeno dotado de uma prática social, para além da perspectiva mercadológica que se impõe em nossos tempos, significa esforço por refletir em novas possibilidades de desenvolvimento. Neste sentido, a tese da humanização do turismo proposta por Krippendorf com vistas ao desenvolvimento de um turismo mais "leve" propiciaria uma prática turística mais harmoniosa entre as pessoas. Mais adequado para quem recebe e, consequentemente para aquele que está em condição de visitante. Outro efeito de ressonância do turismo dentro desta perspectiva, seria o de humanização das cidades.

Almeja-se o desenvolvimento do turismo para a formação de sociedades mais justas e solidárias, conscientes da condição de igualdade entre os seres humanos e natureza, considerando, acima de tudo, a qualidade de vida e a felicidade dos sujeitos, que deve ser o verdadeiro fim de todas as ações humanas no planeta Terra. 


\section{REFERÊNCIAS}

ALBUQUERQUE, Francisco Llorens. Desenvolvimento Econômico Local Caminhos e Desafios para a Construção de uma Nova Agenda Política. 1.ed. Rio de Janeiro: BNDES, 2001.

ALINCOURT, Luis d'. Memória sobre a viagem do porto de Santos à cidade de Cuiabá. Brasília: Senado Federal, Conselho Editorial, 2006.

ALMEIDA, Maria Geralda. "Políticas Públicas e delineamento do espaço turístico goiano". IN: ALMEIDA, Maria Geralda (org.). Abordagens geográficas de Goiás: o natural e o social na contemporaneidade. Goiânia: IESA, 2002. P.197-221.

ANTUNES, Ricardo. Os sentidos do Trabalho: ensaio sobre a afirmação e a negação do trabalho. 3.ed. São Paulo: Boitempo, 2000.

A Dialética do Trabalho - Escritos de Marx e Engels. 2.ed.São Paulo: Expressão Popular, 2013.

AROCENA, Jose. El desarrollo local: um desafio contemporâneo. Uruguai: Taurus, Universid Católica, 2002.

BAIARD, Daniel Cerqueira. Conhecimento, evolução e complexidade na filosofia sintética de Herbert Spencer. Dissertação de Mestrado em Filosofia. Faculdade de Filosofia, Letras e Ciência Humanas. Universidade de São Paulo. São Paulo, 2008. Disponível em: http://www.teses.usp.br/teses/disponiveis/8/8133/tde-10022009125210/pt-br.php. Acesso em: 25 abr.2014.

BARQUERO, Antônio Vázquéz. Desenvolvimento Endógeno em Tempos de Globalização.1.ed.Porto Alegre: Universidade Federal do Rio Grande do Sul Fundação de Economia e Estatística, 2001.

BENI, Mário. Análise estrutural do turismo. 9ª ed. São Paulo: Editora Senac, 2003.

Política e Planejamento de Turismo no Brasil. São Paulo: Aleph, 2006.

BERTRAN, Paulo (org e ed.). Notícia Geral da Capitania de Goiás. Brasília: Solo Editores, 1996.

BIELCHOWSKY, Ricardo (Org.).Cinquenta anos de pensamento na CEPAL. Rio de Janeiro: Record, 2000. 
BOISIER, Sérgio. Desarrollo (Local): ¿ De qué estamos hablando? Artículo publicado en Madoery, Oscar y Vázquez Barquero, Antonio (eds.), Transformaciones globales, Instituciones y Políticas de desarrollo local. Editorial Homo Sapiens, Rosario, 2001. Disponível em http://tecrenat.fcien.edu.uy/Economia/clases/boisier.pdf. Acesso em: 14 Jul.2014.

. Em busca do esquivo Desenvolvimento Regional: Entre a Caixa-preta e - Projeto Político, 1996. Disponível em http://www.ipea.gov.br/ppp/index.php/PPP/article/view/135. Acesso em: 14 Jul.2014.

Sociedad del Conocimiento, Conocimiento Social y Gestión Territorial. IN: Becker (Org.). Desenvolvimento Local-Regional - Respostas Regionais aos Desafios da Globalização.Vol.2.Santa Cruz do Sul: EDUNISC, 2002.

BOLSANELLO, Maria Augusta. Darwinismo social, eugenia e racismo "científico": sua repercussão na sociedade e na educação brasileiras. Artigo científico. Revista Educar, n. 12, p.154-155. 1996. Universidade Federal do Paraná. Curitiba: Editora UFPR, 1996. Disponível em: http://www.educaremrevista.ufpr.br. Acesso em: 25 abr.2014.

BOURDIEU, Pierre. Efeitos de Lugar. In: A miséria do mundo. Petrópolis: Vozes, 1999.

BRASIL. Plano nacional de turismo: diretrizes, metas e programas (20032007).Brasília: Ministério do Turismo, 2003. Disponível em: http://www.turismo.gov.br/. Acesso em: 15 mar.2014.

Plano nacional de turismo: Uma viagem de inclusão (2007-2010). Brasília: Ministério do Turismo, 2007. Disponível em: http://www.turismo.gov.br/. Acesso em: 15 mar.2014.

Plano nacional de turismo: O Turismo fazendo muito mais pelo Brasil (2013-2016).Brasília: Ministério do Turismo, 2003. Disponível em: http://www.turismo.gov.br/. Acesso em: 24 abr.2014.

Estudo de competitividade dos 65 destinos indutores do desenvolvimento turístico regional - relatório Brasil. Organização de Luiz Gustavo Medeiros Barbosa. 2.ed. Brasília: Ministério do Turismo, 2008. Disponível em: http://www.turismo.gov.br/. Acesso em: 25 mar.2014.

Índice de Competitividade do Turismo nacional. Destinos Indutores do desenvolvimento turístico regional - Pirenópolis, 2011. Brasília: Ministério do Turismo, 2012. 
Índice de Competitividade do Turismo nacional. Destinos Indutores do desenvolvimento turístico regional - Pirenópolis, 2014. Brasília: Ministério do Turismo, 2015.

Avaliação do programa de regionalização do turismo - roteiros do Brasil: resumo executivo. Coordenação Técnica do Projeto de Ricardo Ramos de Cerqueira. Brasília: Ministério do Turismo, 2010. Disponível em: http://www.turismo.gov.br/. Acesso em: 28 jul. 2014.

BRUYNE, Paul, et al. Dinâmica da pesquisa nas ciências sociais: os polos das práticas metodológicas. Rio de Janeiro: Francisco Alves, 1977.

CARLOS, Ana F. Da Organização à produção do espaço. In: ( ) A condição espacial. São Paulo: Contexto, 2011. pp. 63-88.

CARVALHO, Adelmo. Pirenópolis Coletânea: 1727-2000. Goiânia: Kelps, 2001.

CHEPTULIN, Alexandre. A dialética materialista: categorias e leis da dialética. São Paulo, Alfa-Omega, 2004.

COMISSÃO MUNDIAL SOBRE MEIO AMBIENTE E DESENVOLVIMENTO. Nosso Futuro Comum. Rio de Janeiro, Editora da Fundação Getúlio Vargas, 1991.

COSTA, Everaldo B. Intervenções em centros urbanos no período da globalização. Revista Cidades. Unesp, Presidente Prudente, V.9 N. 16, 2013.

.Fundamentos de uma emergente patrimonialização global. Revista Geografia. Unesp, Rio Claro,V.39.N.2, 2014.

CURADO, Gloria Grace. Pirenópolis: Uma cidade para o turismo. Goiânia: Oriente, 1978.

CRUZ, Rita de Cássia Arizada. Política de turismo e território. 2.ed.São Paulo: Contexto, 2001.

DARWIN, Charles. Origem das Espécies. 2.ed.São Paulo: Escala, 2008.

DEMO, Pedro. A metodologia do conhecimento científico. São Paulo: Atlas, 2000 Metodologia Científica em Ciências Sociais. São Paulo: Atlas, 1995. 
.Cidadania tutelada e cidadania assistida. Campinas: Autores Associados, 1995b.

DE MASI, Domenico. Desenvolvimento Sem Trabalho. São Paulo: Esfera, 1999.

DIAS, Alessandra S. Mercado Turístico e o curso de Tecnologia em Gestão do Turismo. Pirenópolis: Universidade Estadual de Goiás, 2014.

FALEIRO, Flávio Fernandes; LOPES, Luciana Maria. Aspectos da Mineração e Impactos da Exploração de Quartzito em Pirenópolis-Go. Ateliê Geográfico, Goiânia: v.4,n.3, p.148-162, ago. 2010. Disponível em: http://www.revistas.ufg.br/index.php/atelie/article/view/16655/10101. Acesso em: 24 jun.2014.

FERNANDES, Florestan. A revolução burguesa no Brasil: ensaio de interpretação sociológica. 3. ed. Rio de Janeiro: Guanabara, 1987.

FURTADO, Celso. Teoria e Política do Desenvolvimento Econômico. 9.ed.São Paulo: Nacional, 1986.

FUSFELD, Daniel R. A Era do Economista. São Paulo: Saraiva, 2003.

GASTAL, Susana; MOESCH, Marutschka. Turismo, políticas públicas e cidadania. São Paulo: Aleph, 2007.

GOIÁS. Plano Plurianual - 2000-2003. Goiás. Goiânia: SEPLAN, 2000.

. Plano Plurianual - 2004-2007. Goiás. Goiânia: SEPLAN, 2004.

. Plano Plurianual - 2008-2011. Goiás. Goiânia: SEPLAN, 2008.

. Plano Plurianual - 2012-2015. Goiás. Goiânia, SEPLAN, 2012.

Plano Estadual do Turismo de Goiás (PET-GO): diretrizes, estratégias e programas. Goiânia: Goiás Turismo, 2008.

Qualifica Goiás - Programa de Qualificação. Goiânia: Goiás Turismo, 2010. 
. Plano Municipal de Turismo de Pirenópolis. Pirenópolis: SEBRAE, 2012.

. Reformas administrativas - 4 Décadas de transformação no Poder Executivo. Goiás. Goiânia: SEPLAN, 2005 Disponível em: http://www.sgc.goias.gov.br/upload/arquivos/2011-07/quatro-decadas.pdf . Acesso em: 31 jan.2013.

. Lei Estadual 7988, de 11 de Novembro de 1975. Disponível em: http://www.gabinetecivil.go.gov.br/pagina_leis.php?id=8761. Acesso em: 31 jan.2013. GOLDENBERG, Mirian. A arte de pesquisar - Como fazer pesquisa qualitativa em Ciências Sociais. Rio de janeiro: Record, 1999.

HADDAD, Paulo. Revista de Economia v. 35, n. 3 (ano 33), p.119-146, Curitiba: Editora UFPR, set./dez. 2009.

HAESBAERT, Rogério. Territórios alternativos. 2.ed. São Paulo: Contexto, 2006.

HARVEY, David. Condição Pós Moderna - Uma Pesquisa sobre as Origens da Mudança Cultural. 23.ed.São Paulo: Loyola, 2012.

A produção capitalista do espaço. São Paulo: Annablume, 2005.

HEIDEMANN, Francisco G. . Do sonho do progresso às políticas de desenvolvimento. In: HEIDEMANN, Francisco G.; SALM, José F. (Org.). Políticas Públicas e Desenvolvimento: bases epistemológicas e modelos de análise. 2.ed. Brasília: Universidade de Brasília, 2010.

JAYME, Jarbas. Esboço histórico de Pirenópolis. Pirenópolis: Prefeitura Municipal de Pirenópolis, 1971.

KRIPPENDORF, Jost. Sociologia do turismo. Para uma nova compreensão do lazer e das viagens. São Paulo: Aleph, 2009.

LEFEBVRE, Henri. A Sociedade Burocrática de consumo dirigido. In: A vida cotidiana do mundo moderno. São Paulo: Ática, 1991.

MARX, Karl. O Capital. São Paulo: Nova Cultural, 2001.

Contribuição a crítica da economia política. 2.ed.São Paulo: Expressão

Popular, 2008. 
MARX, Karl; ENGELS, Friedrich. Manifesto do Partido Comunista. 2.ed. Rio de Janeiro: Cátedra, 1987.

MOESCH, Marutschka. A Produção do Saber Turístico. São Paulo, Contexto, 2000.

.O fazer-saber turístico. In: GASTAL, Susana (org.). Turismo, 9 propostas para um saber-fazer. Porto Alegre, RS: EDIPUCRS, 2000b.(p.11 - 28).

. Epistemologia Social do Turismo. Tese de Doutorado em Comunicação - Escola de Comunicação e Arte. Universidade de São Paulo. 2004.

. “Dimensão Social". In: BENI, Mario Carlos (org.). Turismo, planejamento estratégico e capacidade de gestão - desenvolvimento regional, rede de produção e clusters. Barueri, SP: Manole, 2012. (p. 203 - 218).

MOLINA, Sérgio. El modelo indústria turística. In: Conceptualización del turismo. México: Limusa, 2000.

MOLINA, Sergio; RODRÍGUES, Sergio. Planejamento integral do turismo: um enfoque pra a América Latina. Tradução de Carlos Valero. Bauru-SP: EDUSC, 2001.

MORIN, Edgar. Terra Pátria. Porto Alegre: Sulina, 2000.

.Introdução ao pensamento complexo. Porto Alegre: Sulina, 2006.

OMT. Código mundial de ética do turismo. Santiago do Chile, 1999. Disponível em:<http://www.world-tourism.org/code_ethics/pdf/languages/Portugal.pdf./>. Acesso em: 15 de fev. 2014.

OMT, WTTC \& EARTH COUNCIL. Agenda 21 for the Travel \& Tourism Industry Towards Environmentally Sustainable Development. S.I., s.e.,1996. Disponível em: <http://www.wttc.org/promote/agenda21.html>. Acesso em: 20 de abril de 2014.

PALACÍN, Luis.; MORAES, Maria Augusta de S. História de Goiás. Goiânia: Ed. da UCG. 1994.

PAULO NETTO, José. Introdução ao Estudo do Método de Marx. São Paulo: Expressão Popular, 2011. 
PÊCHEUX, Michel. Languages, no 81: Analyse de discours: nouveaux parcours: hommage à Michel Pêcheux (1986); Michel Pêcheux: Discurso: Estrutura ou Acontecimento (Campinas, 1990).

PIRENÓPOLIS. LEI COMPLEMENTAR N 002/ 02 - Plano Diretor. Pirenópolis, 2002.

POHL, Johann Emanuel. Viagem no interior do Brasil. São Paulo: Itatiaia v.14, 1976.

RAFFESTIN, Claude. Por uma geografia do poder. Tradução de Maria Cecília França. São Paulo: Ática, 1993.

RICARDO, David. Princípios de Economia Política e Tributação. São Paulo: Nova Cultural, 1996.

SACHS, Ignacy. Estratégias de transição para o século XXI: desenvolvimento e meio ambiente. São Paulo: Studio Nobel/Fundação do Desenvolvimento Administrativo, 1993.

Caminhos para o Desenvolvimento Sustentável. Rio de Janeiro: Garamond, 2000.

. Desenvolvimento: includente, sustentável, sustentado. Rio de Janeiro: Garamond, 2008.

SAINT-HILAIRE, Auguste de. Viagem à Província de Goiás - Escritos históricos 1819. Belo Horizonte: Itatiaia, 1978.

SANTOS, Boaventura S. "As revoluções da indignação e as lutas democráticas". Palestra proferida em São Paulo. São Paulo, Cortez, 2013. Disponível em: http://www.youtube.com/watch?v=8WVE30YsKvA. Acesso em: 21 abr.2014.

SANTOS, Milton. Espaço e método. São Paulo: Nobel, 1985.

Metamorfoses do espaço habitado: fundamentos teóricos e metodológicos da Geografia. São Paulo: Hucitec, 1996. Edusp, 2002.

A natureza do espaço: técnica e tempo. Razão e emoção. São Paulo: O espaço do cidadão. São Paulo: EDUSP, 2002. 
SEN, Amartya. Desenvolvimento Como Liberdade. São Paulo: Companhia das Letras, 2010.

SILVA, Adailton Lopes Torres da. Estado, Planejamento e Gestão pública em Goiás: os governos Mauro Borges Teixeira e Marconi Perillo. Goiânia. Faculdade de Ciências Humanas e Filosofia (dissertação de mestrado), UFG, 2003.

SIQUEIRA, Josafat Carlos de. Pirenópolis: identidade territorial e biodiversidade. Rio de Janeiro: Loiola, 2001.p.19.

SMITH, Adam. A Riqueza das Nações. São Paulo: Nova Cultural, 1996.

SOUZA, Cibeli de.;CARNEIRO, Maria Esperança. Retrospectiva histórica de Goiás: Da colônia á atualidade. Goiânia: UFG,1996.

STANDING, Guy. O precariado. A nova classe perigosa. Belo Horizonte: Autêntica, 2013.

SZTOMPKA, Piotr. A Sociologia da Mudança Social. Rio de Janeiro: Civilização Brasileira, 1998.

VILLAR, Alejandro. Políticas públicas em turismo In: WALLINGRE, Noemí; VILLAR, Alejandro (Comp.). Desarrollo y gestión de destinos turísticos: políticas y estrategias. Bernal: Universidad Nacional de Quilmes, 2009.

YIN, Robert. Estudo de caso: planejamento e métodos. 3.ed. Porto Alegre: Bookman, 2009. 
APÊNDICE A - Entrevista: Gestor Municipal do Turismo de Pìrenópolis

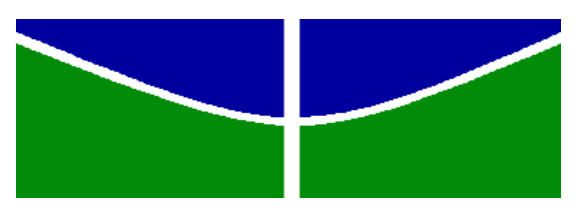

Universidade de Brasília Centro de Excelência em Turismo Mestrado Profissional em Turismo

Esta entrevista é parte integrante da dissertação intitulada "Pirenópolis: Limites e possibilidades de desenvolvimento pelo turismo", que tem como intuito compreender as relações de capital e trabalho, e, as transformações sócio econômicas decorrentes destas e suas influências no processo de desenvolvimento do Turismo no município de Pirenópolis.

Nome:

\section{Formação:}

1- O que você entende por turismo?

2- Em sua opinião, o turismo praticado em Pirenópolis atende á essa concepção?

3- Qual a sua concepção de desenvolvimento?

4- Quais os impactos da política nacional no desenvolvimento do turismo local? Em sua visão, como está sendo a atuação de Pirenópolis como "destino indutor"?

5- Que mudanças ocorreram na definição de Pirenópolis como "destino indutor" no tocante á geração de empregos?

6- A partir da implantação do programa de regionalização houve melhora da qualificação dos trabalhadores que atuam no turismo? De que forma? 
7- Em sua opinião, quais são as principais dificuldades em se desenvolver o turismo em Pirenópolis?

8- O que você entende por desenvolvimento sustentável? E atualmente a política pública do turismo local contempla essa concepção?

9- As ações que visam o desenvolvimento do turismo impactam além da região central, também os povoados? De que forma?

10-0 grau de maturidade do empresário pirenopolino do setor do turismo e de serviços em geral tem contribuído para a melhora do desenvolvimento sustentável da cidade?

11 - 0 incremento dos postos de trabalho através das empresas turísticas melhorou as condições dos trabalhadores (salário, formalização, qualificação) ou manteve se a precarização existente historicamente na região?

Muito obrigada pela disponibilidade de seu tempo e pela contribuição. 
APÊNDE B - Entrevista: Membros das Associações Representativas e Empresários do Turismo Local

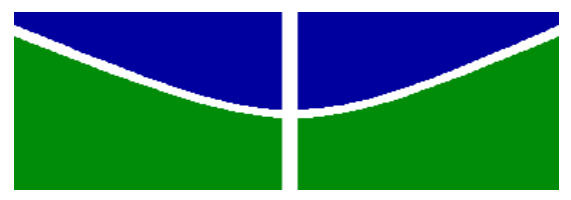

Universidade de Brasília Centro de Excelência em Turismo Mestrado Profissional em Turismo

Esta entrevista é parte integrante da dissertação intitulada "Pirenópolis: Limites e possibilidades de desenvolvimento pelo turismo", que tem como intuito compreender as relações de capital e trabalho, e, as transformações sócio econômicas decorrentes destas e suas influências no processo de desenvolvimento do Turismo no município de Pirenópolis.

Nome:

Empresa:

1- O que você entende por turismo?

2- Qual a sua concepção de desenvolvimento?

3- Caso você tenha conhecimento sobre a política nacional de turismo, em sua opinião, quais os impactos desta no desenvolvimento do turismo local? Avalie como está sendo a atuação de Pirenópolis como "destino indutor".

4- Você tem ciência de que existe uma política municipal do turismo? Em caso afirmativo, em que medida tem contribuído ou não para o desenvolvimento do turismo local?

5- Em sua opinião, 0 incremento dos postos de trabalho através das empresas turísticas propiciou alguma mudança nas relações de trabalho, emprego e renda no município? Em caso afirmativo, quais?

6- Quais são os principais desafios enfrentados para o desenvolvimento de seu negócio? 
7-A sua empresa implantou ou é parceira de algum projeto de responsabilidade socioambiental? Quais?

8- Dentre os seus fornecedores (de materiais e prestadores de serviços) qual o percentual que são de Pirenópolis?

9- Sua empresa tem alguma política de qualificação para os seus empregados? Descreva.

10- Qual o tipo de vínculo que a sua empresa mantém com seus trabalhadores (terceirizado, diarista, contrato seletivo)?

11- Desses trabalhadores qual é o percentual de mulheres? Tem alguma assistência financeira ou mesmo física como creche para as mães ou a responsabilidade fica a cargo do Estado?

12- Para o funcionamento de seu negócio, com que frequência você solicita horas extras a seus trabalhadores, e geralmente como a empresa os remunera, em banco de horas ou monetariamente?

13- Descreva quais seriam os benefícios que a sua empresa oferece a seus trabalhadores.

Muito obrigada pela disponibilidade de seu tempo e pela contribuição. 
APÊNDICE C - Entrevista: Trabalhadores do Turismo Local
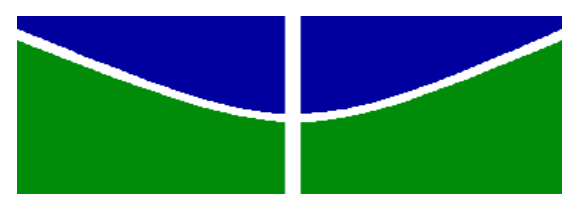

Universidade de Brasília Centro de Excelência em Turismo Mestrado Profissional em Turismo

Esta entrevista é parte integrante da dissertação intitulada "Pirenópolis: Limites e possibilidades de desenvolvimento pelo turismo", que tem como intuito compreender as relações de capital e trabalho, e, as transformações sócio econômicas decorrentes destas e suas influências no processo de desenvolvimento do Turismo no município de Pirenópolis.

Nome:

Grau de escolaridade/formação:

1. Há quanto tempo trabalha na área do turismo e em que atividade você trabalhava anteriormente?

2- Descreva a sua jornada de trabalho.

(quantas horas trabalha por dia, quantos dias da semana, qual o tempo de intervalos para o almoço ou jantar e lanches/ em que dias da semana geralmente folga/ forma de recebimento das horas extras, se remuneradas ou em banco de horas)

3- Avalie as suas condições de trabalho na empresa em que trabalha atualmente (instalações, higiene das instalações, conforto, segurança, equipamentos utilizados para realizar seu trabalho)

4-Recebe algum benefício da empresa, como alimentação, transporte, assistência médica ou outros?

5- Você tira férias regularmente? Quando tem férias tira o tempo integral (30 dias corridos)? 
6- Sua renda está acima ou abaixo do salário mínimo vigente? Além dessa renda, você recebe algum adicional tais como comissão sobre vendas, bônus por bater metas, participação nos lucros da empresa, entre outros?

7- Quais os cursos de qualificação que você possui na área do turismo? Na sua opinião, qual a importância da qualificação para o desenvolvimento do seu trabalho?

8- A empresa na qual trabalha lhe incentiva ou proporciona condições para realização de estudo formal e/ou cursos de qualificação na área do turismo? De quê forma?

9- Houve alteração na sua vida a partir do momento em que você começou a trabalhar com o turismo? De que forma?

10- Na sua opinião, qual é a importância do turismo para Pirenópolis?

Muito obrigada pela disponibilidade de seu tempo e pela contribuição. 
APÊNDICE D - Quadro interpretativo de trechos do discurso do documento:

Plano Nacional de Turismo 2003-2007

\begin{tabular}{|c|c|c|c|}
\hline \multicolumn{2}{|l|}{ TEMAS } & & \\
\hline \multirow{4}{*}{$\begin{array}{c}\text { Desenvolvimento } \\
\text { Sustentável e Includente }\end{array}$} & $\mathbf{R}$ & Concepção & $\begin{array}{l}\text { - Desenvolvimento Sustentável = "Promover, } \\
\text { através do turismo, um desenvolvimento regional } \\
\text { equilibrado". Desenvolver o turismo de forma } \\
\text { sustentável nas comunidades, para o PNT, se } \\
\text { resume a concessão de infraestrutura e } \\
\text { investimentos, geração de divisas e empregos. }\end{array}$ \\
\hline & C & Dificuldades & $\begin{array}{l}\text { - Compreender a sustentabilidade em sua } \\
\text { totalidade e monitorar os efeitos/ impactos do } \\
\text { turismo contemplando todas as dimensões desta } \\
\text { (ambiental, cultural, político institucional, social } \\
\text { e econômica). A visão do PNT está atrelada a } \\
\text { ganhos econômicos, equilíbrio da balança } \\
\text { comercial e ingresso de novas divisas. } \\
\text { Sustentabilidade entra apenas como uma } \\
\text { justificativa para algumas ações. }\end{array}$ \\
\hline & & Avanços & $\begin{array}{l}\text { - O comprometimento (pelo menos em tese) com } \\
\text { a geração de empregos, com a valorização e } \\
\text { conservação do patrimônio cultural e natural, e o } \\
\text { acesso de novas camadas sociais ao turismo, } \\
\text { além da adoção dos princípios gerais contidos no } \\
\text { Código Mundial da Ética no Turismo da OMT } \\
\text { (1999). }\end{array}$ \\
\hline & $S$ & $\begin{array}{l}\text { Totalidade/ } \\
\text { Fragmentação }\end{array}$ & $\begin{array}{l}\text {-Objetivo do PNT-“constituir o turismo } \\
\text { em um fator de desenvolvimento consequente } \\
\text { e equilibrado em todo território nacional”, no } \\
\text { entanto, para que o desenvolvimento regional } \\
\text { ocorra principalmente de forma sustentável e } \\
\text { equilibrada, devem ser consideradas questões } \\
\text { alheias ao turismo; a sustentabilidade depende de } \\
\text { outras políticas públicas ligadas à educação, meio } \\
\text { ambiente, saúde, cultura e trabalho. Depende } \\
\text { também na qualidade na educação, na oferta de } \\
\text { serviços de saúde, mecanismos de proteção ao } \\
\text { meio ambiente e ao patrimônio e diversidade } \\
\text { cultural (como leis, com fiscalização e } \\
\text { cumprimento das mesmas), entre outros que pré- } \\
\text { existem ao turismo nas localidades receptoras; } \\
\text { além da existência e da qualidade da } \\
\text { infraestrutura como saneamento básico } \\
\text { atendendo a maior parte do município, coleta } \\
\text { seletiva e destinação correta do lixo, dentre } \\
\text { outros. }\end{array}$ \\
\hline
\end{tabular}




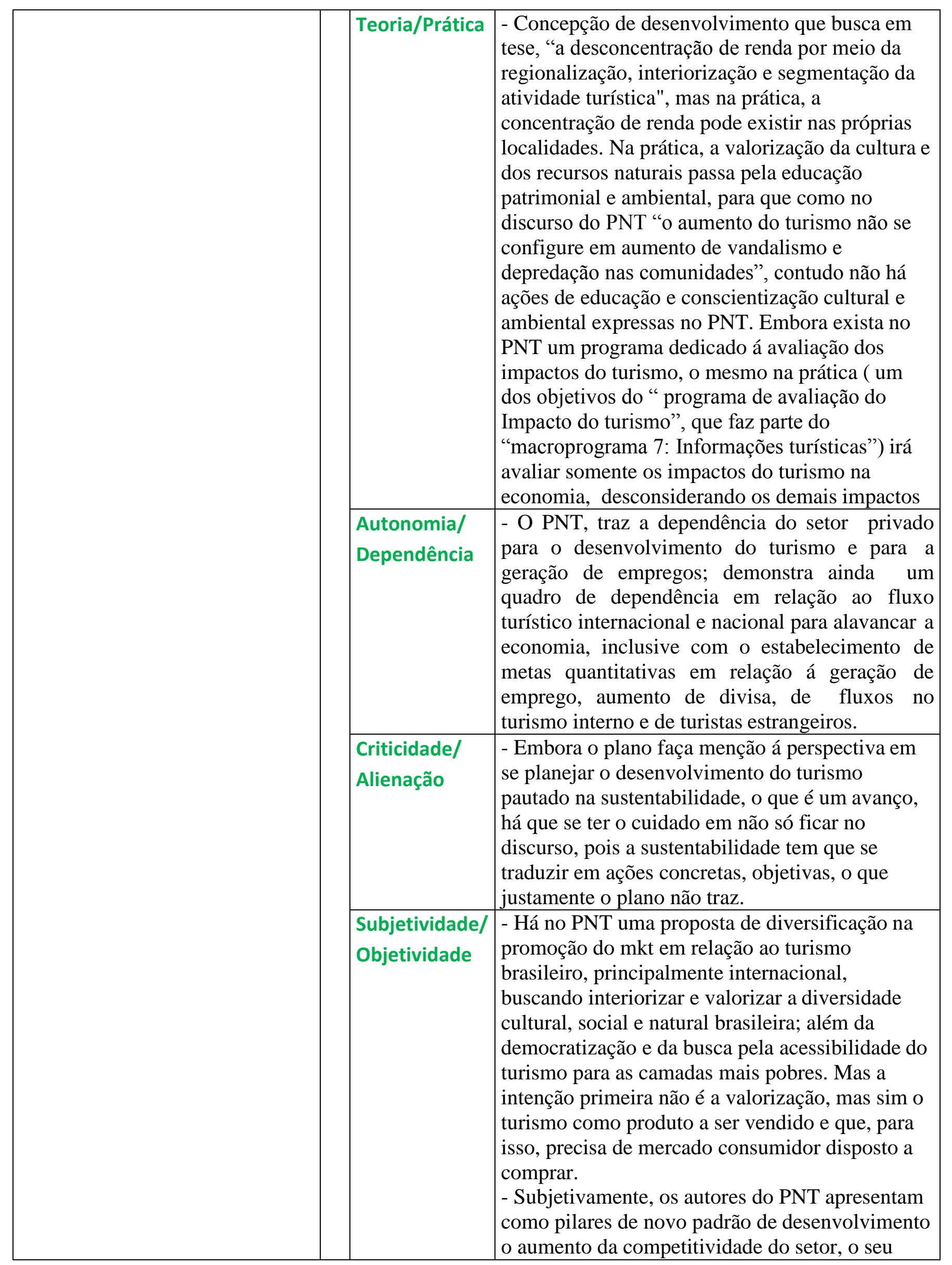




\begin{tabular}{|c|c|c|c|}
\hline & & & $\begin{array}{l}\text { impacto na melhoria das condições de vida da } \\
\text { população, a descentralização das decisões e o } \\
\text { respeito ao meio ambiente, no qual todas as } \\
\text { regiões possam crescer de forma integrada. Mas, } \\
\text { objetivamente, uma melhoria das condições de } \\
\text { vida da população, a tomada de decisões e o } \\
\text { respeito ao meio ambiente estão atrelados ao } \\
\text { aumento da competitividade do setor, estando } \\
\text { portanto nas mãos da iniciativa privada. }\end{array}$ \\
\hline & & $\begin{array}{l}\text { Contradições/ } \\
\text { Mediações }\end{array}$ & $\begin{array}{l}\text { - O PNT em seu discurso revela que está tanto a } \\
\text { serviço do bem estar social, (que é a finalidade } \\
\text { do governo), como a serviço do setor produtivo } \\
\text { (que tem como finalidade o lucro), no entanto, a } \\
\text { maioria dos objetivos estão voltados para atender } \\
\text { aos interesses do capital não só nacional, mas } \\
\text { também atrair o capital estrangeiro. }\end{array}$ \\
\hline \multirow[t]{5}{*}{$\begin{array}{c}\text { Turismo e Políticas } \\
\text { Públicas }\end{array}$} & \multirow[t]{3}{*}{$\begin{array}{l}\text { R } \\
\text { U } \\
\text { B } \\
\text { R } \\
\text { I } \\
\text { C } \\
\text { A } \\
\text { S }\end{array}$} & Concepção & $\begin{array}{l}\text { - Concepção de política pública de turismo: } \\
\text { Simplificada, entendendo que o turismo exige } \\
\text { poucos investimentos. Turismo entendido da } \\
\text { perspectiva de negócio ou produto, interessante } \\
\text { para aquecer a economia e diminuir as } \\
\text { desigualdades regionais, como elemento } \\
\text { propulsor do desenvolvimento socioeconômico } \\
\text { do país. Política pública de turismo se traduz em } \\
\text { ações para a inserção do Brasil no cenário } \\
\text { turístico mundial. }\end{array}$ \\
\hline & & Dificuldades & $\begin{array}{l}\text { - Desafio do MTUR - conceber um novo } \\
\text { modelo de gestão pública, descentralizada e } \\
\text { participativa, atingindo em última instância o } \\
\text { município, onde efetivamente o turismo acontece. }\end{array}$ \\
\hline & & Avanços & $\begin{array}{l}\text { - Criação do Mtur: representa avanço, com suas } \\
\text { indicações a respeito do planejamento } \\
\text { participativo e a busca pela transversalidade entre } \\
\text { o Mtur e outros Ministérios, além da articulação } \\
\text { com governos estaduais e municipais, com o } \\
\text { poder legislativo, com o setor empresarial e a } \\
\text { sociedade organizada. }\end{array}$ \\
\hline & $\begin{array}{l}\text { S } \\
\text { U } \\
\text { B } \\
-\end{array}$ & $\begin{array}{l}\text { Totalidade/ } \\
\text { Fragmentação }\end{array}$ & $\begin{array}{l}\text { - O PNT propõe enquanto vetores do governo, a } \\
\text { redução das desigualdades regionais e sociais, a } \\
\text { geração e distribuição de renda, a geração de } \\
\text { emprego e ocupação, e o equilíbrio do balanço de } \\
\text { pagamentos. Deve-se ter em vista, entretanto, que } \\
\text { essas ações serão desenvolvidas justamente em } \\
\text { uma realidade fragmentada com necessidades } \\
\text { específicas em cada localidade. }\end{array}$ \\
\hline & U & Teoria/Prática & $\begin{array}{l}\text { - A criação do MTur, revela o turismo como } \\
\text { prioridade para o governo, no entanto, na prática } \\
\text { o que ocorre no Brasil são ações pontuais e } \\
\text { desarticuladas com cada ministério cuidando de } \\
\text { suas atribuições de forma não integrada e }\end{array}$ \\
\hline
\end{tabular}




\begin{tabular}{|c|c|c|c|}
\hline & $\mathbf{R}$ & & $\begin{array}{l}\text { relegando ao turismo, dessa forma, um } \\
\text { papel meramente negociativo. }\end{array}$ \\
\hline & C & $\begin{array}{l}\text { Autonomia/ } \\
\text { Dependência }\end{array}$ & $\begin{array}{l}\text { - O Plano demostra uma preocupação excessiva } \\
\text { com a apresentação de números e cumprimento } \\
\text { de metas quantitativas, apresentando dependência } \\
\text { total do crescimento econômico, do setor privado } \\
\text { para que o turismo se desenvolva. }\end{array}$ \\
\hline & & $\begin{array}{l}\text { Criticidade/ } \\
\text { Alienação }\end{array}$ & $\begin{array}{l}\text { - O PNT não se configura enquanto Política } \\
\text { Pública. Ele é um plano que integra o turismo à } \\
\text { macro estratégia do país, se comprometendo a } \\
\text { cumprir um papel fundamental no crescimento } \\
\text { econômico e na redução das desigualdades } \\
\text { sociais }\end{array}$ \\
\hline & & $\begin{array}{l}\text { Subjetividade/ } \\
\text { Objetividade }\end{array}$ & \\
\hline & & $\begin{array}{l}\text { Contradições/ } \\
\text { Mediações }\end{array}$ & $\begin{array}{l}\text { - O PNT tem como meta a criação de no mínimo } \\
81 \text { roteiros integrados contemplando todos os } \\
\text { estados brasileiros e o distrito federal, no entanto, } \\
\text { no diagnóstico do Plano há o reconhecimento de } \\
\text { que é necessário conhecer a oferta turística do } \\
\text { Brasil, ora se há um desconhecimento dessa } \\
\text { oferta bem como de sua distribuição no território } \\
\text { nacional, então como ditar que cada região tenha } \\
3 \text { roteiros, se se desconhece inclusive se há } \\
\text { condições e possibilidade de serem criados essa } \\
\text { quantidade de roteiros em determinadas regiões? }\end{array}$ \\
\hline \multirow{5}{*}{ Espaço; Território } & \multirow{3}{*}{$\begin{array}{l}\text { R } \\
\text { U } \\
\text { B } \\
\text { R }\end{array}$} & Concepção & $\begin{array}{l}\text { - Desenvolver o turismo em todas as regiões, } \\
\text { contemplando todo o território nacional, com } \\
\text { vistas a redução das desigualdades } \\
\text { sociais/regionais. }\end{array}$ \\
\hline & & Dificuldades & $\begin{array}{l}\text { - Compreender e lidar com as diferenças } \\
\text { territoriais ( que envolvem não só relações } \\
\text { econômicas, mas sobretudo relações de poder } \\
\text { local/global, relações culturais, práticas sociais, } \\
\text { relações jurídico-políticas, meio ambiente } \\
\text { naturais diversos). }\end{array}$ \\
\hline & & Avanços & $\begin{array}{l}\text { - O desejo de que o turismo seja desenvolvido em } \\
\text { todo o país, atingindo os níveis municipal, } \\
\text { regional, não só priorizando algumas regiões e/ou } \\
\text { segmentos do turismo é um avanço. }\end{array}$ \\
\hline & \multirow[t]{2}{*}{$\begin{array}{l}\text { S } \\
\text { U } \\
\text { B } \\
-\end{array}$} & $\begin{array}{l}\text { Totalidade/ } \\
\text { Fragmentação }\end{array}$ & $\begin{array}{l}\text { - Embora o PNT tenha como proposito } \\
\text { desenvolver o turismo em todo o território } \\
\text { nacional, os objetivos propostos revelam a } \\
\text { fragmentação do espaço, por exemplo a } \\
\text { contemplação das cidades em detrimento da zona } \\
\text { rural no que tange a melhorias de infra estrutura. }\end{array}$ \\
\hline & & Teoria/Prática & \\
\hline
\end{tabular}




\begin{tabular}{|c|c|c|c|}
\hline & $\mathbf{R}$ & $\begin{array}{l}\text { Autonomia/ } \\
\text { Dependência }\end{array}$ & $\begin{array}{l}\text { - O desenvolvimento do turismo de forma } \\
\text { sustentável também depende políticas de } \\
\text { ordenamento e uso do território. Embora no PNT } \\
\text { haja a menção de que o Ministério da Integração } \\
\text { seja um dos parceiros para o desenvolvimento do } \\
\text { turismo, este colaborará com recursos financeiros } \\
\text { e não com parceria técnica (pelo menos o docto } \\
\text { não explicita isso) para se pensar o } \\
\text { desenvolvimento das regiões, dos territórios. }\end{array}$ \\
\hline & $\mathbf{S}$ & $\begin{array}{l}\text { Criticidade/ } \\
\text { Alienação }\end{array}$ & $\begin{array}{l}\text { - O fato de se estruturar produtos em todos os } \\
\text { estados brasileiros e Distrito Federal, não é garantia } \\
\text { de diminuição das desigualdades regionais, haja } \\
\text { visto que cada território tem suas } \\
\text { especificidades/características e nem todos os } \\
\text { "produtos" criados podem de fato se consolidar, } \\
\text { pois dependem da convergência de ações de uma } \\
\text { ampla rede de sujeitos } \\
\text { públicos/privados/comunidade envolvidos de fato } \\
\text { para a realização e consolidação dos roteiros. } \\
\text { - Enquanto um instrumento de planejamento do } \\
\text { Estado, o PNT também torna se um instrumento } \\
\text { de poder, e como tal o governo o usa na tentativa } \\
\text { de organizar o espaço com vistas ao } \\
\text { desenvolvimento do país, mas também de } \\
\text { subjugá lo á lógica da disseminação da } \\
\text { apropriação capitalista do mesmo, uma vez que a } \\
\text { ênfase toda do Plano está no mercado, com } \\
\text { objetivo de que o turismo atinja todo o território } \\
\text { nacional. }\end{array}$ \\
\hline & & $\begin{array}{l}\text { Subjetividade/ } \\
\text { Objetividade }\end{array}$ & \\
\hline & & $\begin{array}{l}\text { Contradições/ } \\
\text { Mediações }\end{array}$ & $\begin{array}{l}\text { - Há que ter cautela com a estratégia de } \\
\text { imposição da criação de } 3 \text { roteiros para cada } \\
\text { região, justamente evitando cair no mesmo erro } \\
\text { cometido com o PNMT que desconsiderava se os } \\
\text { municípios tinham vocação, potencialidade, } \\
\text { vontade e condições para o desenvolvimento do } \\
\text { turismo. Por exemplo se pensarmos na região } \\
\text { amazônica, onde há dificuldade de acesso, onde } \\
\text { requer uma preocupação maior com o meio } \\
\text { ambiente natural, etc, muitas vezes torna se } \\
\text { difícil a implementação e operacionalização de } \\
\text { certos roteiros, além do custo alto, que pode } \\
\text { inviabilizar a comercialização. }\end{array}$ \\
\hline & B & Concepção & $\begin{array}{l}\text { - No PNT a iniciativa privada é vista como o } \\
\text { fundamental parceiro para o desenvolvimento do } \\
\text { turismo. } \\
\text { - No PNT existem poucas referências aos } \\
\text { trabalhadores do turismo, á exceção da }\end{array}$ \\
\hline
\end{tabular}




\begin{tabular}{|c|c|c|c|}
\hline \multirow{3}{*}{$\begin{array}{c}\text { Relações de } \\
\text { Capital/Trabalho }\end{array}$} & \multirow[t]{3}{*}{$\begin{array}{l}\text { R } \\
\text { I } \\
\text { C } \\
\text { A } \\
\text { S }\end{array}$} & & $\begin{array}{l}\text { qualificação e geração de emprego. Os } \\
\text { trabalhadores do turismo são concebidos } \\
\text { enquanto peças de uma engrenagem maior que é } \\
\text { o turismo visto enquanto atividade econômica; } \\
\text { também são concebidos enquanto consumidores } \\
\text { potenciais. }\end{array}$ \\
\hline & & Dificuldades & $\begin{array}{l}\text { - Promover diálogo entre a iniciativa privada e os } \\
\text { trabalhadores no que tange ás questões que } \\
\text { permeiam essa relação é um desafio ao PNT e ao } \\
\text { MTUR. } \\
\text { - De acordo com o diagnóstico do PNT, as } \\
\text { dificuldades para o desenvolvimento do turismo } \\
\text { por parte setor privado são: inexistência de um } \\
\text { processo de estruturação da cadeia produtiva } \\
\text { impactando a qualidade e a competitividade do } \\
\text { produto turístico brasileiro; regulamentação } \\
\text { inadequada da atividade e baixo controle de } \\
\text { qualidade na prestação de serviços com foco na } \\
\text { defesa do consumidor, oferta de crédito } \\
\text { insuficiente e inadequada para o setor turístico, } \\
\text { baixa qualidade e pouca diversidade de produtos } \\
\text { turísticos ofertados nos mercados nacional e } \\
\text { internacional. } \\
\text { - A deficiência crônica na gestão e } \\
\text { operacionalização de toda infraestrutura básica } \\
\text { (saneamento, água, energia, transportes) e } \\
\text { turística, é uma das dificuldades diagnosticadas } \\
\text { pelo PNT a ser enfrentadas, sobretudo pela } \\
\text { gestão pública, mas que reverberam e tem } \\
\text { implicações no setor privado e na vida das } \\
\text { comunidades que recebem turistas. } \\
\text { - Uma das dificuldades segundo o PNT é a } \\
\text { criação de condições para gerar novos empregos } \\
\text { e ocupações no turismo além de vencer a alta } \\
\text { rotatividade que existe nos postos de trabalho. }\end{array}$ \\
\hline & & Avanços & $\begin{array}{l}\text { - Oferta de linhas de crédito e financiamento aos } \\
\text { empreendedores do turismo, atendendo á } \\
\text { pequena e média empresas empresas pode ser } \\
\text { uma (dentre outras) possibilidade de dar início a } \\
\text { processos de desenvolvimento com base local, } \\
\text { pois pode gerar um estímulo á pessoas das } \\
\text { comunidades para empreenderem em seus } \\
\text { territórios. } \\
\text { - Regulamentação, normatização e fiscalização } \\
\text { do setor. } \\
\text { - A proposta da criação de um programa de } \\
\text { qualificação, bem como a meta de serem criados } \\
\text { empregos e a oferta de crédito ás micro e } \\
\text { pequenas empresas, são outros avanços do Plano. } \\
\text { - O reconhecimento de que na formação dos }\end{array}$ \\
\hline
\end{tabular}




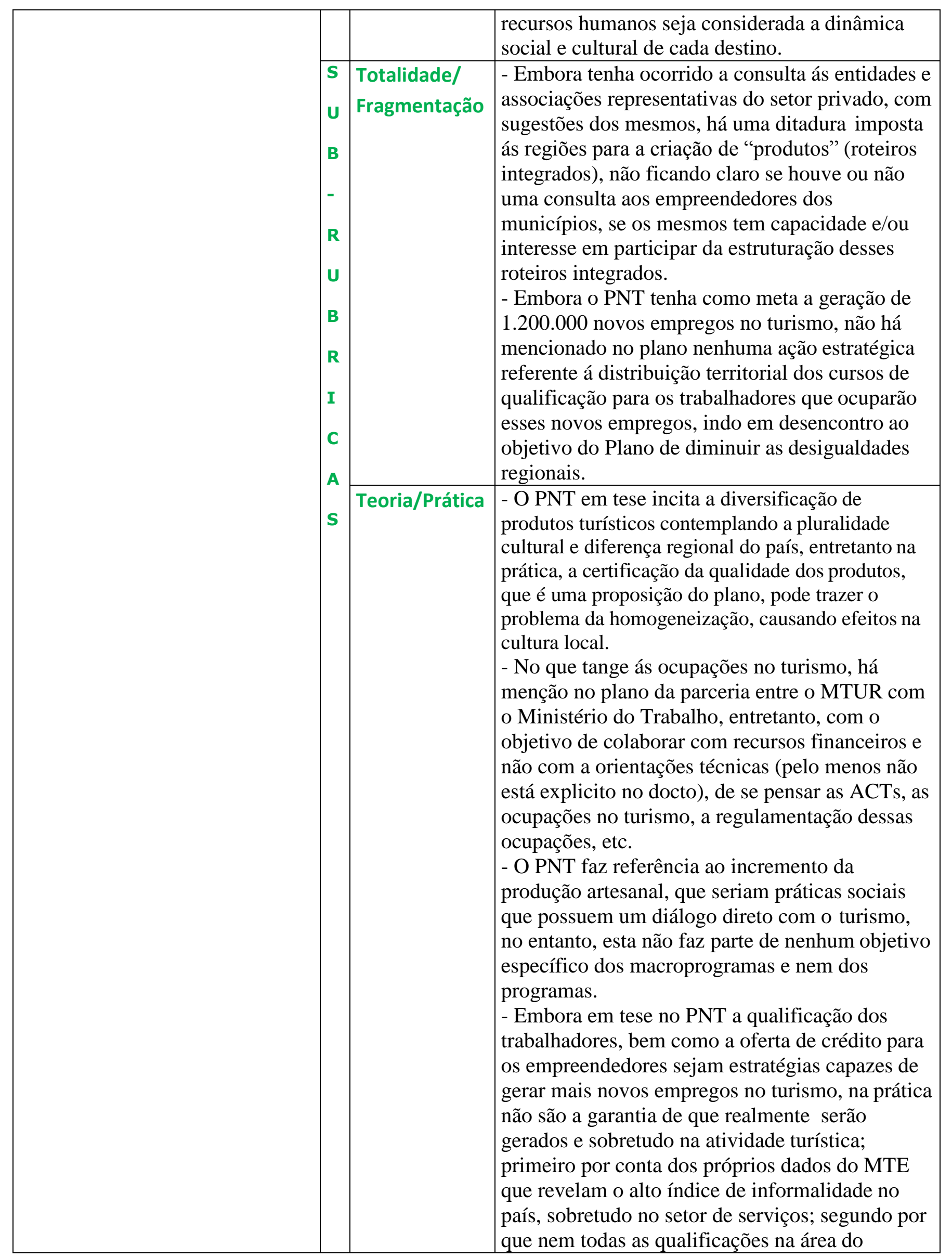




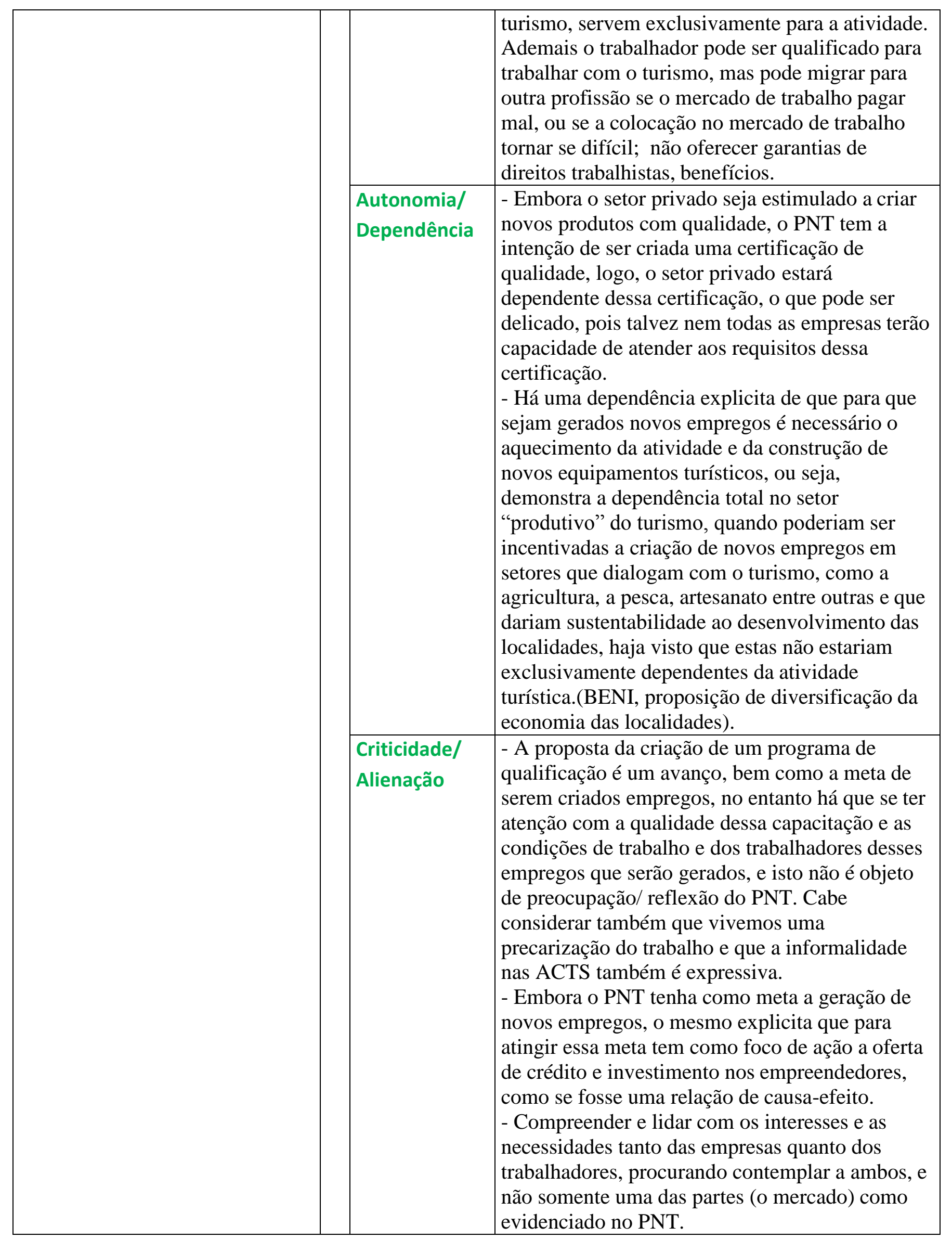




\begin{tabular}{|c|c|c|}
\hline & $\begin{array}{l}\text { Subjetividade/ } \\
\text { Objetividade }\end{array}$ & $\begin{array}{l}\text { - Subjetivamente uma das grandes metas do PNT } \\
\text { é a geração de emprego, entretanto, } \\
\text { objetivamente não são explicitadas ações } \\
\text { concretas, objetivas ( a não ser a qualificaçao e } \\
\text { dependência da iniciativa privada) que levem á } \\
\text { geração dos mesmos. } \\
\text { - Objetivamente, o documento defende o direito } \\
\text { dos trabalhadores ao lazer e às férias, tendo no } \\
\text { turismo um fator de construção da cidadania e de } \\
\text { integração social. Mas subjetivamente, o que se } \\
\text { deseja é a ampliação do mercado consumidor do } \\
\text { turismo no Brasil. }\end{array}$ \\
\hline & $\begin{array}{l}\text { Contradições/ } \\
\text { Mediações }\end{array}$ & $\begin{array}{l}\text { - Embora o diagnóstico do PNT detecte a } \\
\text { inexistência de um processo de estruturação da } \\
\text { cadeia produtiva, o mesmo, ao longo da descrição } \\
\text { e objetivos dos macroprogramas não propõe } \\
\text { ações para tal estruturação, somente algumas } \\
\text { ações pontuais são mencionadas. } \\
\text { - O trabalhador das ACTs é visto como mera } \\
\text { engrenagem para a operacionalização do turismo, } \\
\text { o investimento na qualificação do trabalhador } \\
\text { serve de suporte para que o setor turístico se } \\
\text { beneficie, com pessoas melhores qualificadas que } \\
\text { resultará em um melhor serviço prestado ao } \\
\text { turista. } \\
\text { - Os investimentos propostos pelo PNT se } \\
\text { limitam ao financeiro e nem chegam a articular } \\
\text { ações com os ministérios do Trabalho e Emprego } \\
\text { e Renda. O fato do turismo exigir poucos } \\
\text { investimentos, a qualificação dos recursos } \\
\text { humanos ser rápida, além destes não serem } \\
\text { substituídos por máquinas passa pela ideia da } \\
\text { facilidade, o de investir o mínimo possível nas } \\
\text { pessoas e na área, contradizendo a fala onde o } \\
\text { turismo seria uma prioridade do Governo. }\end{array}$ \\
\hline \multirow[t]{2}{*}{ Cidadania } & Concepção & $\begin{array}{l}\text { - O plano pouco faz menção á cidadania e a } \\
\text { cidadãos, a única proposição é o incentivo (em } \\
\text { tese) á participação comunitária nos processos de } \\
\text { planejamento e gestão do turismo, além de } \\
\text { compreender cidadãos enquanto possíveis } \\
\text { consumidores. } \\
\text { - O discurso do PNT é centrado na gestão } \\
\text { descentralizada e no fomento á participação, há } \\
\text { inclusive incentivos para que as comunidades se } \\
\text { organizem em Conselhos de turismo para refletir } \\
\text { e planejar o turismo. }\end{array}$ \\
\hline & Dificuldades & $\begin{array}{l}\text { - A principal dificuldade está na real valorização } \\
\text { da participação e dos conhecimentos locais para a } \\
\text { gestão do turismo. Pois apesar do discurso de } \\
\text { elaboração participativa do PNT, nota-se que ele }\end{array}$ \\
\hline
\end{tabular}




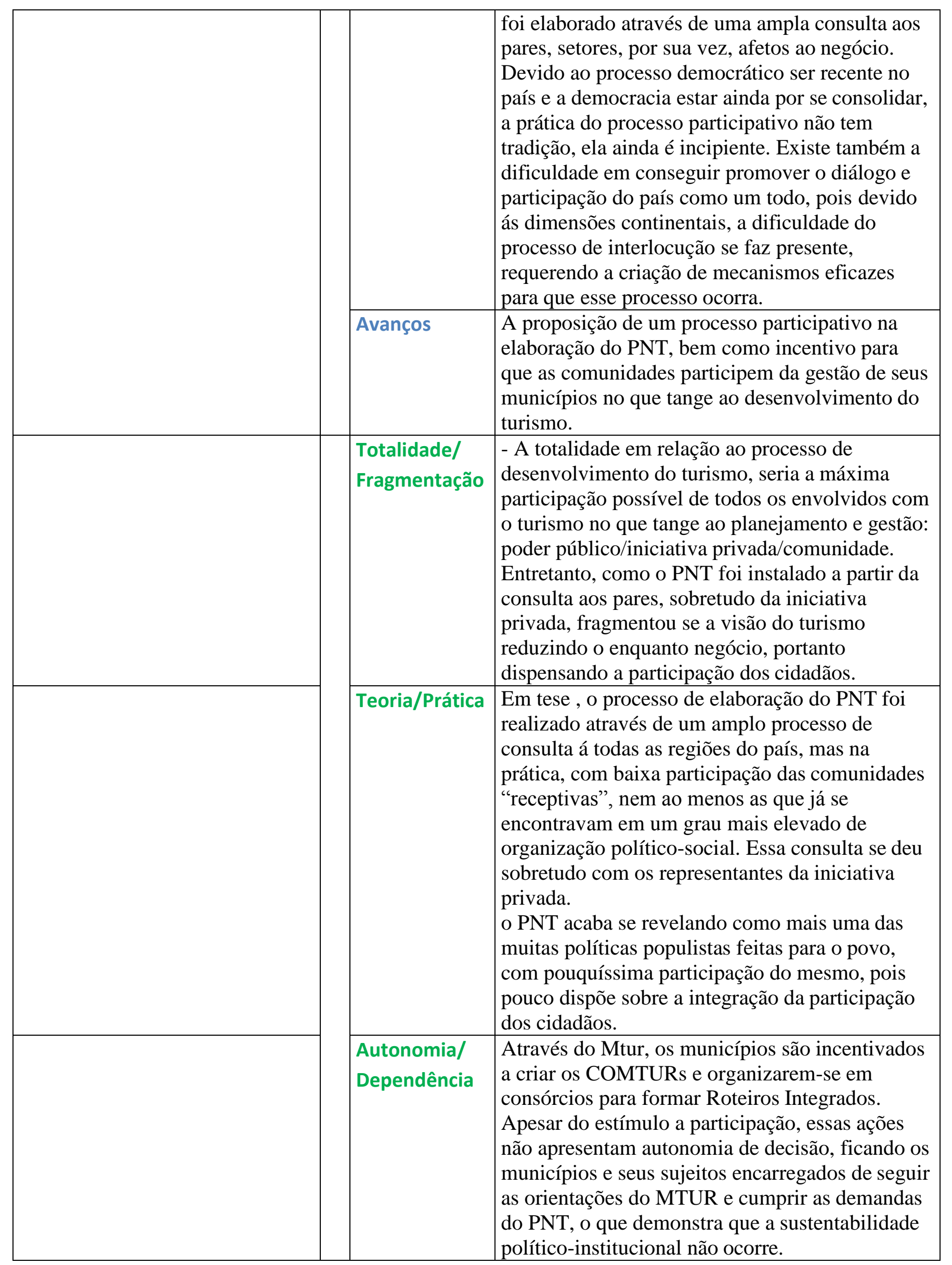




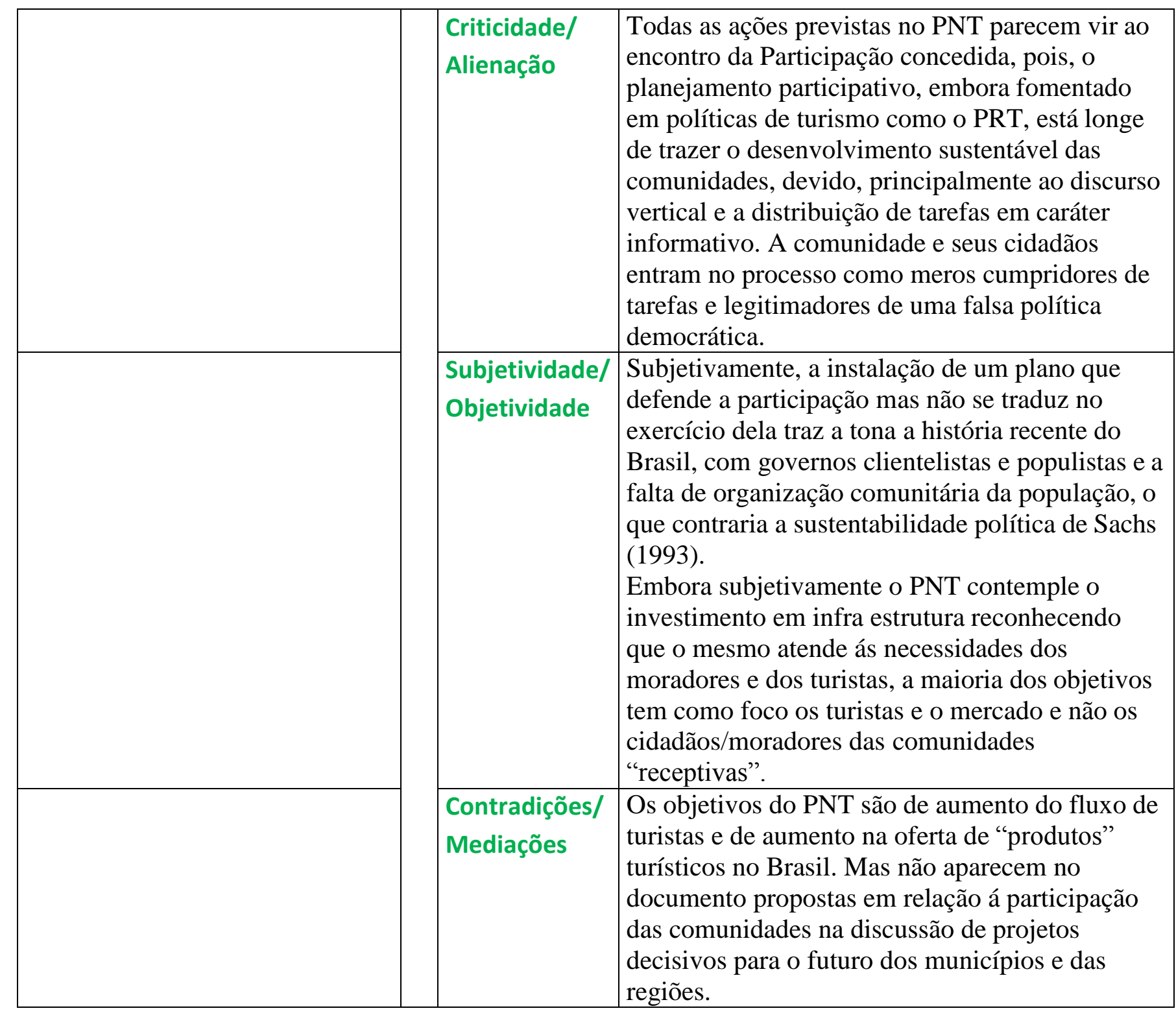




\section{APÊNDICE E - Quadro interpretativo de trechos do discurso do documento:}

\section{Plano Nacional de Turismo 2007-2010}

\begin{tabular}{|c|c|c|c|}
\hline \multicolumn{2}{|l|}{ TEMAS } & & \\
\hline \multirow[t]{5}{*}{$\begin{array}{c}\text { Desenvolvimento } \\
\text { Sustentável e Includente }\end{array}$} & \multirow[t]{3}{*}{$\begin{array}{l}\text { R } \\
\text { U } \\
\text { B } \\
\text { R } \\
\text { I } \\
\text { C } \\
\text { A } \\
\text { S }\end{array}$} & Concepção & $\begin{array}{l}\text {-"A consolidação, de forma sustentável, da atividade } \\
\text { turística no Brasil deve resultar do fortalecimento do } \\
\text { mercado interno, sem desconsiderar a importância da } \\
\text { chegada de turistas estrangeiros, que proporciona a } \\
\text { geração de divisas para o País. O processo de } \\
\text { desenvolvimento sustentável nas sociedades } \\
\text { modernas está vinculado à disponibilidade e } \\
\text { acessibilidade ao crédito, para expansão dos negócios } \\
\text { que realizam as atividades de produção de cada setor } \\
\text { econômico". O discurso revela que a sustentabilidade } \\
\text { na prática é entendida somente do ponto de vista } \\
\text { econômico. A inclusão social para o PNT se dá } \\
\text { somente através da geração de emprego e renda e } \\
\text { do acesso ao consumo do turismo. }\end{array}$ \\
\hline & & Dificuldades & $\begin{array}{l}\text { - Carência em termos de infra estrutura de apoio ao } \\
\text { turismo no país, principalmente no que se refere á } \\
\text { acessibilidade e saneamento ambiental, porém } \\
\text { existem financiamentos em curso concedidos pelo } \\
\text { BID para o PRODETUR JK (que contempla a região } \\
\text { centro oeste, no entanto está sendo elaborado um } \\
\text { plano estratégico de desenvolvimento, além de } \\
\text { investimentos do PAC. }\end{array}$ \\
\hline & & Avanços & $\begin{array}{l}\text { - Turismo continua ser pautado no Código Mundial de } \\
\text { Etica no Turismo da OMT. } \\
\text { - Ações de proteção á crianças e adolescentes no que } \\
\text { tange a erradicação da exploração sexual infantil pelo } \\
\text { turismo. } \\
\text { - Reconhecimento da importância de o turismo ser } \\
\text { desenvolvido (pelo menos em tese) através de uma } \\
\text { gestão responsável com base na sustentabilidade, } \\
\text { considerando as dimensões ambiental, social, cultural } \\
\text { e econômica. } \\
\text { - Diálogo com a produção associada ao turismo. Ação } \\
\text { concreta de apoio á divulgação e comercialização dos } \\
\text { produtos. Cursos de qualificação para os artesãos } \\
\text { voltados ao fortalecimento organizacional e ao } \\
\text { empreendedorismo. Patrocínio do Mtur aos artesãos } \\
\text { participarem de eventos do setor com vistas a } \\
\text { divulgação e comercialização de seus produtos. }\end{array}$ \\
\hline & $S$ & $\begin{array}{l}\text { Totalidade/ } \\
\text { Fragmentação }\end{array}$ & $\begin{array}{l}\text { Embora esse PNT apresente avanços no que } \\
\text { tange á concepção de desenvolvimento } \\
\text { sustentável e includente ( quando comparado ao } \\
\text { PNT anterior), eles ainda não contemplam a } \\
\text { totalidade do que seria um desenvolvimento } \\
\text { sustentável e includente. }\end{array}$ \\
\hline & & Teoria/Prática & $\begin{array}{l}\text { - Certificação dos meios de hospedagem no que } \\
\text { tange a sustentabilidade, na prática serve de suporte }\end{array}$ \\
\hline
\end{tabular}




\begin{tabular}{|c|c|c|c|}
\hline & $\mathbf{R}$ & & $\begin{array}{l}\text { para incrementar a competitividade do turismo } \\
\text { brasileiro. } \\
\text { - Em tese o PNT discursa que o desenvolvimento tem } \\
\text { que se dar de forma sustentável, entretanto na } \\
\text { prática, os objetivos referentes á } \\
\text { sustentabilidade(descritos no macroprograma de infra } \\
\text { estrutura pública), se resumem em "garantir a } \\
\text { qualidade e sustentabilidade dos destinos turísticos; } \\
\text { garantir as condições adequadas para que o } \\
\text { desenvolvimento do turismo se dê de forma } \\
\text { sustentável". Só que a melhoria da infra estrutura } \\
\text { não é garantia de que o desenvolvimento seja } \\
\text { sustentável. }\end{array}$ \\
\hline & $\mathbf{S}$ & $\begin{array}{l}\text { Autonomia/ } \\
\text { Dependência }\end{array}$ & $\begin{array}{l}\text { - O PNT, continua revelando a dependência do setor } \\
\text { privado para o desenvolvimento do turismo; } \\
\text { demonstra ainda um quadro de dependência em } \\
\text { relação ao fluxo turístico internacional e nacional, no } \\
\text { entanto nesse momento focado de forma veemente } \\
\text { no nacional, para alavancar a economia, inclusive } \\
\text { com o estabelecimento de metas quantitativas em } \\
\text { relação á geração de emprego, aumento de divisa, } \\
\text { de fluxos de turistas a sobretudo no turismo interno. }\end{array}$ \\
\hline & & $\begin{array}{l}\text { Criticidade/ } \\
\text { Alienação }\end{array}$ & $\begin{array}{l}\text { Embora o PNT reconheça que os impactos } \\
\text { econômicos, sociais, ambientais, políticos e culturais } \\
\text { gerados pelo turismo exigem um processo de } \\
\text { planejamento e gestão que oriente, discipline e se } \\
\text { constitua em um poderoso instrumento de aceleração } \\
\text { do desenvolvimento nos níveis local, regional e } \\
\text { nacional, o plano traz somente em um de seus } \\
\text { programas a avaliação dos impactos econômicos o } \\
\text { que revela que a preocupação e atenção com a } \\
\text { sustentabilidade se dá somente considerando a } \\
\text { dimensão econômica desta. }\end{array}$ \\
\hline & & $\begin{array}{l}\text { Subjetividade/ } \\
\text { Objetividade }\end{array}$ & $\begin{array}{l}\text { - A proposta de democratização e inclusão social } \\
\text { do turismo para as camadas mais pobres, } \\
\text { possibilitando que essas pessoas tenham acesso } \\
\text { ao turismo, tem como intenção primeira ampliar } \\
\text { o mercado consumidor, uma vez que o foco/meta } \\
\text { desse PNT está na ampliação do turismo interno. }\end{array}$ \\
\hline & & $\begin{array}{l}\text { Contradições/ } \\
\text { Mediações }\end{array}$ & $\begin{array}{l}\text { - O PNT em seu discurso revela que tem como } \\
\text { objetivo a garantir que o desenvolvimento do } \\
\text { turismo se dê de forma sustentável, no entanto a } \\
\text { maioria dos objetivos estão voltados para atender } \\
\text { aos interesses do capital não só nacional, mas } \\
\text { também atrair o capital estrangeiro. }\end{array}$ \\
\hline $\begin{array}{c}\text { Turismo e Políticas } \\
\text { Públicas }\end{array}$ & I & Concepção & $\begin{array}{l}\text { O turismo é concebido enquanto atividade } \\
\text { econômica, indutora do desenvolvimento (numa } \\
\text { perspectiva regional), da geração de emprego e } \\
\text { renda e de inclusão social. A política nacional de } \\
\text { A política pública está traduzida no PNT, como } \\
\text { "um instrumento de planejamento e gestão } \\
\text { descentralizada e participativa (em tese), } \\
\text { composto por metas, macroprogramas e } \\
\text { programas que tem como objetivos colocar o }\end{array}$ \\
\hline
\end{tabular}




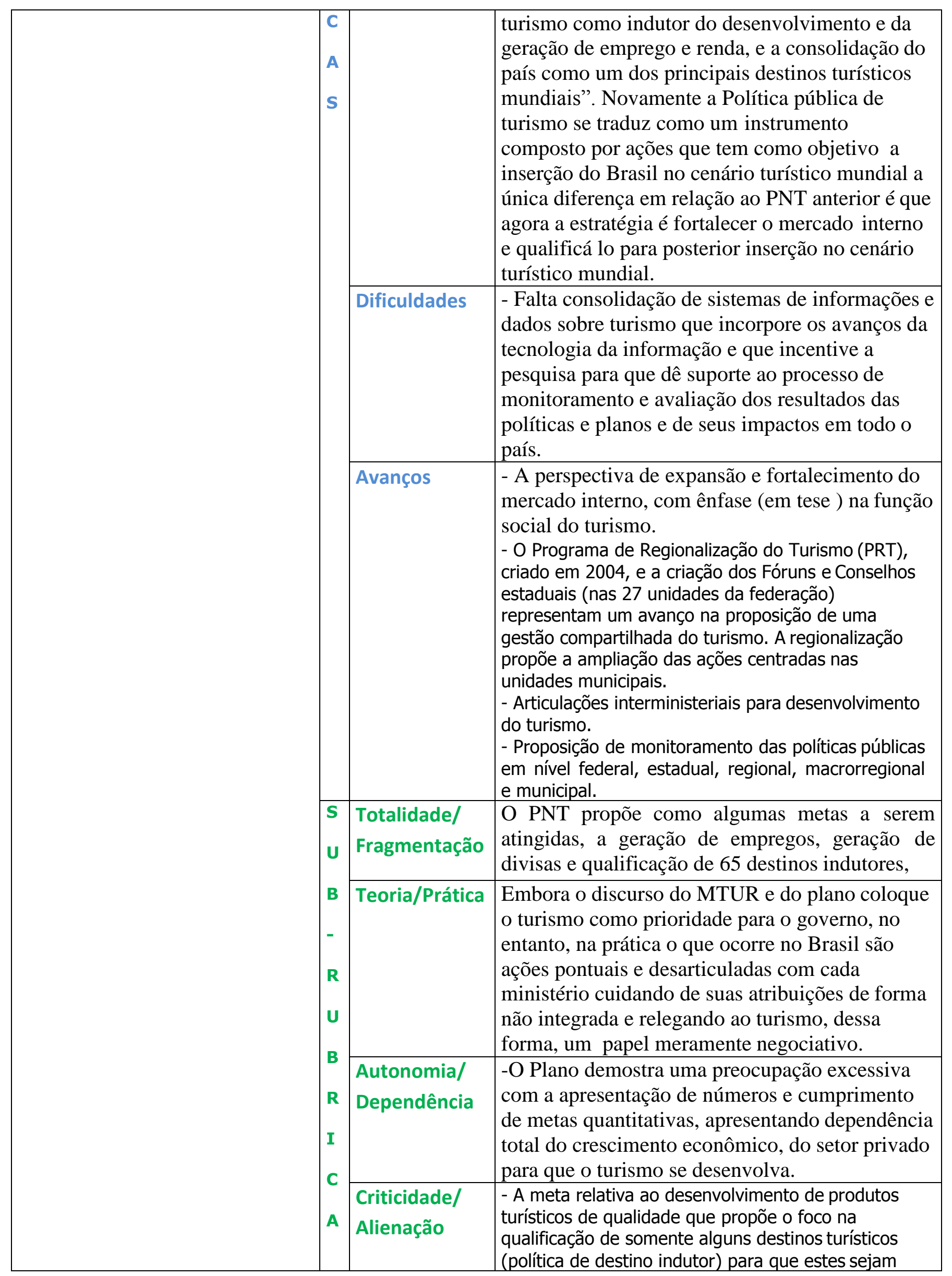




\begin{tabular}{|c|c|c|c|}
\hline & $\mathrm{S}$ & & $\begin{array}{l}\text { indutores dos demais destinos da região, pode ser } \\
\text { uma faca de dois gumes, pois o destino pode se } \\
\text { bastar e usar essa política para promoção e } \\
\text { marketing do destino e não cumprir com seu objetivo } \\
\text { que é induzir os demais destinos da região turística a } \\
\text { se organizarem e desenvolverem também. }\end{array}$ \\
\hline & & $\begin{array}{l}\text { Subjetividade/ } \\
\text { Objetividade }\end{array}$ & \\
\hline & & $\begin{array}{l}\text { Contradições/ } \\
\text { Mediações }\end{array}$ & $\begin{array}{l}\text { - A proposta de descentralização da execução de } \\
\text { ações do PNT, em alinhamento com programas } \\
\text { macrorregionais, estaduais, regionais e municipais } \\
\text { pode ser uma faca de dois gumes, pois ao mesmo } \\
\text { tempo que o alinhamento de ações seja importante, } \\
\text { dependendo do grau de maturidade/autonomia do } \\
\text { município, esta descentralização pode se tornar em } \\
\text { apenas cumprimento das ações do PNT por parte do } \\
\text { município, e este não se empenhar em focar e } \\
\text { desenvolver outras ações que sejam compatíveis com } \\
\text { a realidade e necessidades locais. } \\
\text { - Embora seja um avanço a parceria efetuada com a } \\
\text { academia, esta parceria se restringe ao programa de } \\
\text { qualificação e ao programa de competitividade, essas } \\
\text { parcerias e aproximações poderiam ser estendidas } \\
\text { não só para o apoio a outros programas mas também } \\
\text { na proposição de ações, na reflexão e construção de } \\
\text { uma concepção de turismo, etc. }\end{array}$ \\
\hline \multirow{4}{*}{ Espaço; Território } & \multirow{3}{*}{$\begin{array}{l}\text { R } \\
\text { U } \\
\text { B } \\
\text { R } \\
\text { I } \\
\text { C } \\
\text { A } \\
\text { S }\end{array}$} & Concepção & $\begin{array}{l}\text { - O PRT assimila a noção de território como } \\
\text { espaço e lugar de interação do homem com o } \\
\text { ambiente, dando origem a diversas maneiras de se } \\
\text { organizar e se relacionar com a natureza, com a } \\
\text { cultura e com os recursos de que dispõe. Essa noção } \\
\text { supõe formas de coordenação entre organizações } \\
\text { sociais, agentes econômicos e representantes } \\
\text { políticos, superando a visão estritamente setorial do } \\
\text { desenvolvimento. }\end{array}$ \\
\hline & & Dificuldades & $\begin{array}{l}\text { - Há o reconhecimento de que o turismo encontra se } \\
\text { ainda bastante concentrado territorialmente, o desafio } \\
\text { seria a descentralização e interiorização do turismo. }\end{array}$ \\
\hline & & Avanços & $\begin{array}{l}\text { - Um dos objetivos do Parte a desconcentração da } \\
\text { oferta turística brasileira, localizada } \\
\text { predominantemente no litoral, propiciando } \\
\text { a interiorização da atividade. } \\
\text { - O desenvolvimento do turismo de forma } \\
\text { sustentável também depende políticas de } \\
\text { ordenamento e uso do território, neste sentido o } \\
\text { PNT } 2007 \text { apresenta um avanço, pois menciona o } \\
\text { apoio para a elaboração de Planos diretores, nos } \\
\text { municípios que precisam reavalia lós. }\end{array}$ \\
\hline & $\mathrm{S}$ & $\begin{array}{l}\text { Totalidade/ } \\
\text { Fragmentação }\end{array}$ & $\begin{array}{l}\text { - Embora o PNT tenha como proposito } \\
\text { desenvolver o turismo em todo o território } \\
\text { nacional, os objetivos propostos continuam a }\end{array}$ \\
\hline
\end{tabular}




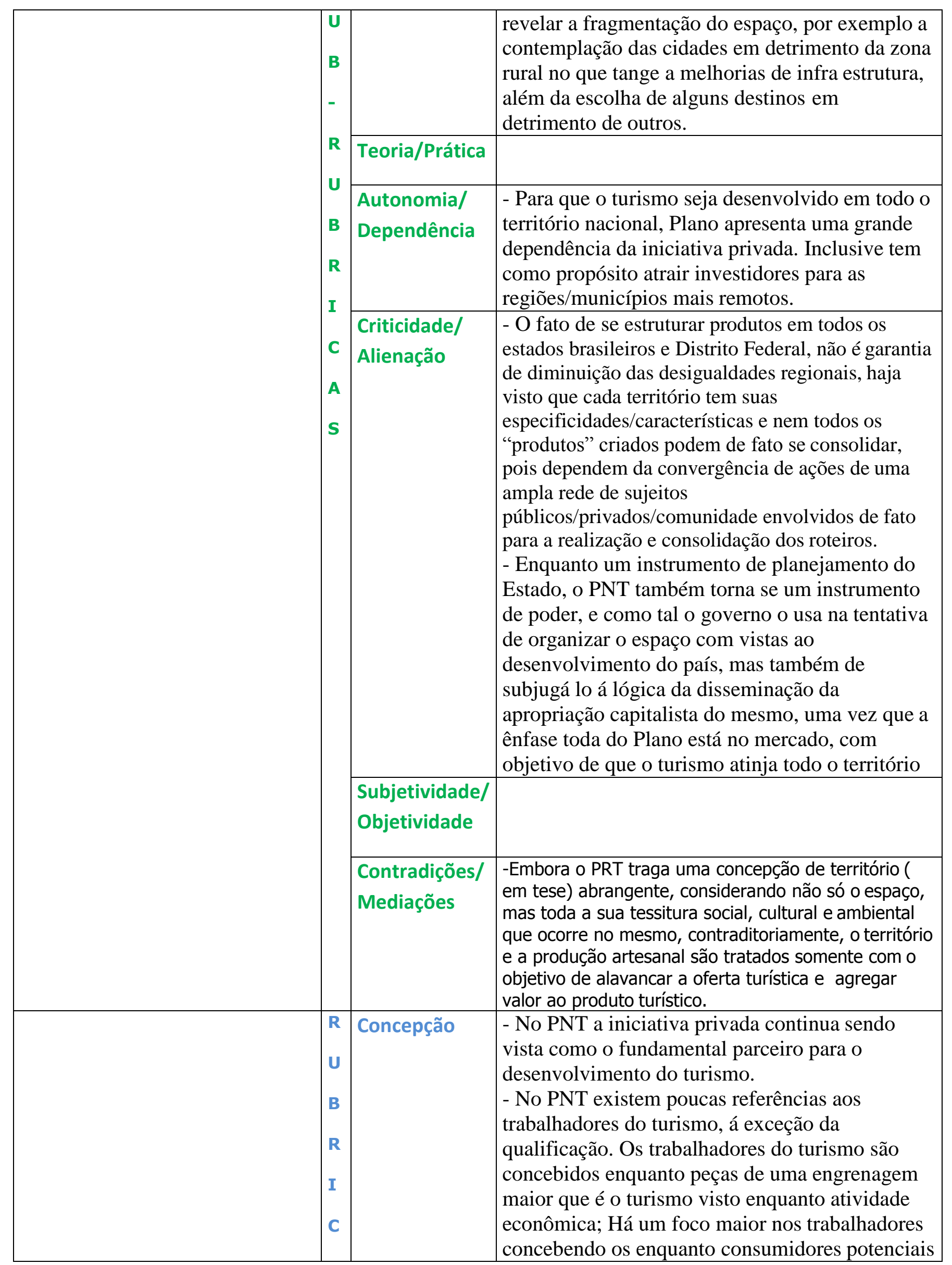




\section{Relações de Capital/Trabalho}

\begin{tabular}{|c|c|c|}
\hline \multirow[t]{3}{*}{ A } & & que alavancarão o turismo. \\
\hline & Dificuldades & $\begin{array}{l}\text { - MPEs continuam tendo limitações no acesso ao } \\
\text { crédito para investimentos. } \\
\text { - Carência de infra estrutura tanto de apoio ao } \\
\text { turismo (saneamento, acessibilidade) como } \\
\text { propriamente turística (sinalização turística, CATs,etc) } \\
\text { é um outro entrave para que haja expansão, } \\
\text { diversificação e desconcentração da oferta turística. } \\
\text {-Embora existam diversas instituições educacionais } \\
\text { que atuam na área de qualificação profissional do } \\
\text { turismo, de acordo com o PNT nem sempre essa } \\
\text { atuação se dá de forma integrada e articulada, } \\
\text { resultando em sobreposição de esforços e desperdício } \\
\text { de recursos. Além disso, são bastante frágeis as } \\
\text { análises diagnósticas, voltadas a levantar, } \\
\text { quantitativa e qualitativamente, as necessidades de } \\
\text { qualificação profissional e empresarial para o turismo. } \\
\text { Outro desafio de acordo com o PNT, é a existência de } \\
\text { entraves para se alcançar a excelência no } \\
\text { atendimento e na prestação de serviços, devido aos } \\
\text { trabalhadores do turismo apresentarem baixa } \\
\text { escolaridade, terem baixa remuneração e alta } \\
\text { rotatividade, além de a percepção da qualificação } \\
\text { profissional como investimento estar apenas se } \\
\text { iniciando na cultura empresarial. }\end{array}$ \\
\hline & Avanços & \\
\hline $\mathbf{S}$ & $\begin{array}{l}\text { Totalidade/ } \\
\text { Fragmentação }\end{array}$ & $\begin{array}{l}\text { - Embora o PNT tenha como meta a geração de } \\
1.700 .000 \text { novos empregos no turismo, não há } \\
\text { mencionado no plano nenhuma ação estratégica } \\
\text { referente á distribuição territorial dos cursos de } \\
\text { qualificação para os trabalhadores que ocuparão } \\
\text { esses novos empregos, indo em desencontro ao } \\
\text { objetivo do Plano de diminuir as desigualdades } \\
\text { regionais. }\end{array}$ \\
\hline $\mathbf{U}$ & Teoria/Prática & $\begin{array}{l}\text { - Embora a geração de emprego e renda possa ser } \\
\text { um dos muitos elementos de inclusão social, na } \\
\text { prática a qualificação profissional no PNT é } \\
\text { apenas um meio para o aumento da } \\
\text { competitividade dos destinos e melhoria para a } \\
\text { qualidade dos serviços ofertados. } \\
\text {-A certificação de profissionais do turismo de } \\
\text { aventura na prática foi priorizada para } \\
\text { incrementar a competitividade do turismo e não } \\
\text { com vistas á melhoria do trabalhador e de seu } \\
\text { trabalho. } \\
\text { - Embora em tese no PNT a qualificação dos } \\
\text { trabalhadores, bem como a oferta de crédito para } \\
\text { os empreendedores sejam estratégias capazes de } \\
\text { gerar mais novos empregos no turismo, na prática } \\
\text { não são a garantia de que realmente serão } \\
\text { gerados e sobretudo na atividade turística; }\end{array}$ \\
\hline
\end{tabular}




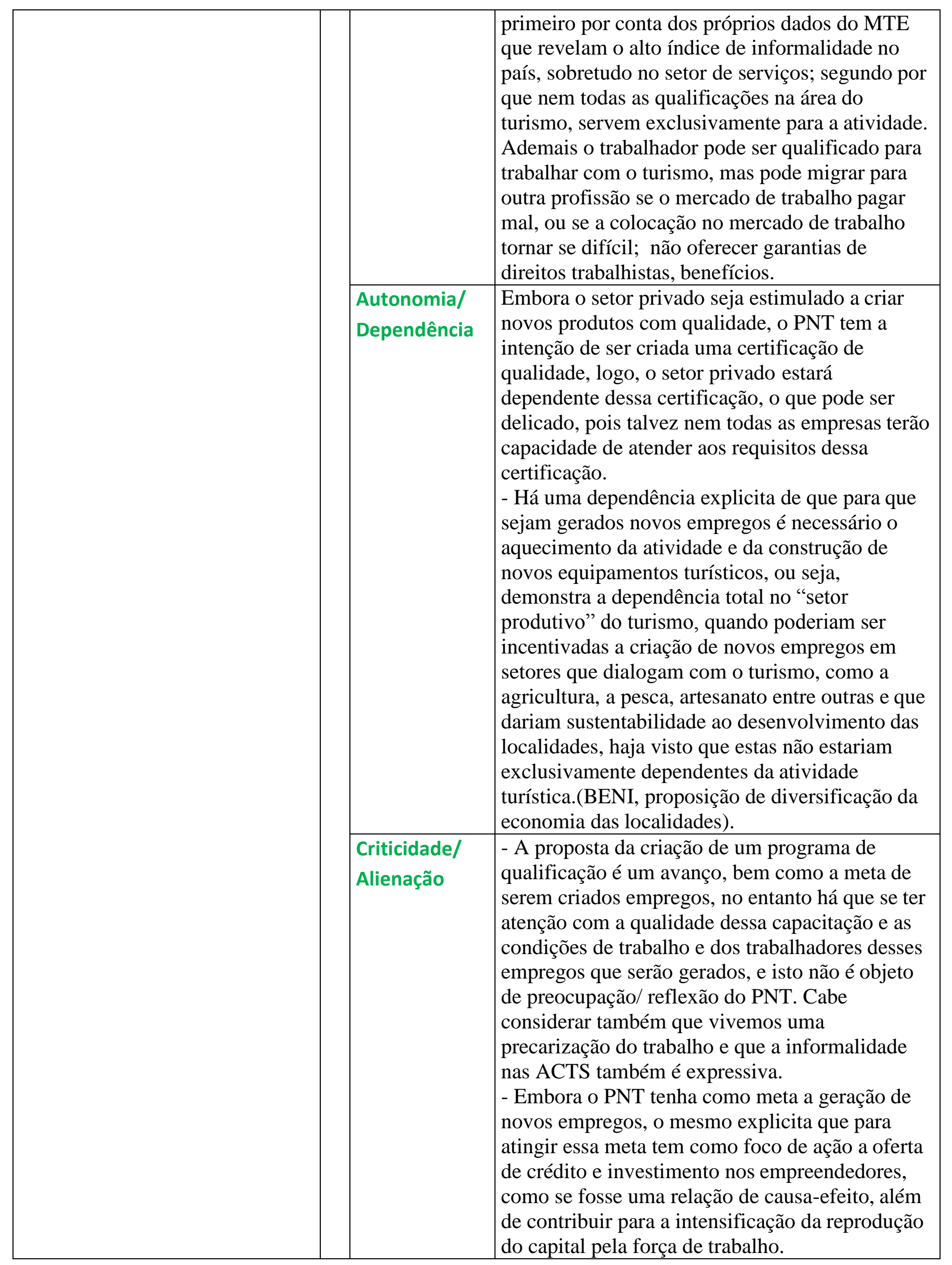




\begin{tabular}{|c|c|c|c|}
\hline & & & $\begin{array}{l}\text { - Compreender e lidar com os interesses e as } \\
\text { necessidades tanto das empresas quanto dos } \\
\text { trabalhadores, procurando contemplar a ambos, e } \\
\text { não somente o mercado como evidenciado no } \\
\text { PNT. }\end{array}$ \\
\hline & & $\begin{array}{l}\text { Subjetividade/ } \\
\text { Objetividade }\end{array}$ & $\begin{array}{l}\text { - Objetivamente, o documento defende o direito } \\
\text { dos trabalhadores ao lazer e às férias, tendo no } \\
\text { turismo um fator de construção da cidadania e de } \\
\text { integração social. Mas subjetivamente, o que se } \\
\text { deseja é a ampliação do mercado consumidor do } \\
\text { turismo no Brasil. }\end{array}$ \\
\hline & & $\begin{array}{l}\text { Contradições/ } \\
\text { Mediações }\end{array}$ & $\begin{array}{l}\text { - Embora o diagnóstico do PNT detecte a } \\
\text { inexistência de um processo de estruturação da } \\
\text { cadeia produtiva, o mesmo, ao longo da descrição } \\
\text { e objetivos dos macroprogramas não propõe } \\
\text { ações para tal estruturação, somente algumas } \\
\text { ações pontuais são mencionadas. } \\
\text { - O trabalhador das ACTs é visto como mera } \\
\text { engrenagem para a operacionalização do turismo, } \\
\text { o investimento na qualificação do trabalhador } \\
\text { serve de suporte para que o setor turístico se } \\
\text { beneficie, com pessoas melhores qualificadas que } \\
\text { resultará em um melhor serviço prestado ao } \\
\text { turista. } \\
\text { - Os investimentos propostos pelo PNT se } \\
\text { limitam ao financeiro e nem chegam a articular } \\
\text { ações com os ministérios do Trabalho e Emprego } \\
\text { e Renda. O fato do turismo exigir poucos } \\
\text { investimentos, a qualificação dos recursos } \\
\text { humanos ser rápida, além destes não serem } \\
\text { substituídos por máquinas passa pela ideia da } \\
\text { facilidade, o de investir o mínimo possível nas } \\
\text { pessoas e na área, contradizendo a fala onde o } \\
\text { turismo seria uma prioridade do Governo. }\end{array}$ \\
\hline \multirow[t]{2}{*}{ Cidadania } & \multirow[t]{2}{*}{$R$} & Concepção & $\begin{array}{l}\text { "Promover o turismo com um fator de inclusão } \\
\text { social, por meio da geração de trabalho e renda } \\
\text { e pela inclusão da atividade na pauta de consumo } \\
\text { de todos os brasileiros". } \\
\text { - O plano pouco faz menção á cidadania e a } \\
\text { cidadãos, a única proposição é o incentivo (em } \\
\text { tese) á participação comunitária nos processos de } \\
\text { planejamento e gestão do turismo, além de } \\
\text { compreender cidadãos enquanto possíveis } \\
\text { consumidores. }\end{array}$ \\
\hline & & Dificuldades & $\begin{array}{l}\text { - A principal dificuldade está na real valorização } \\
\text { da participação e dos conhecimentos locais para a } \\
\text { gestão do turismo. Pois apesar do discurso de } \\
\text { elaboração participativa do PNT, nota-se que ele } \\
\text { foi elaborado através de uma ampla consulta aos } \\
\text { pares, setores, por sua vez, afetos ao negócio. } \\
\text { Devido ao processo democrático ser recente no }\end{array}$ \\
\hline
\end{tabular}




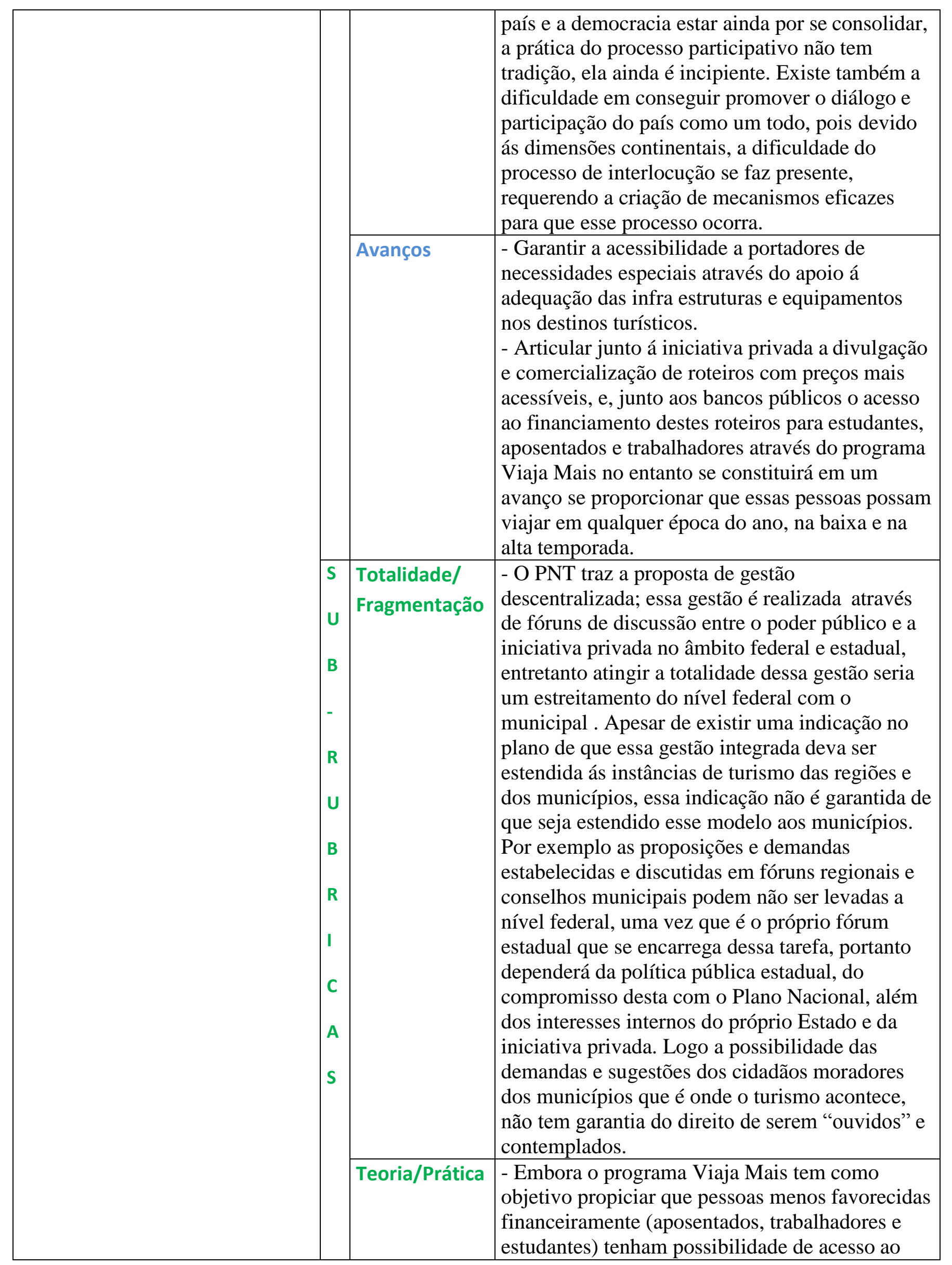




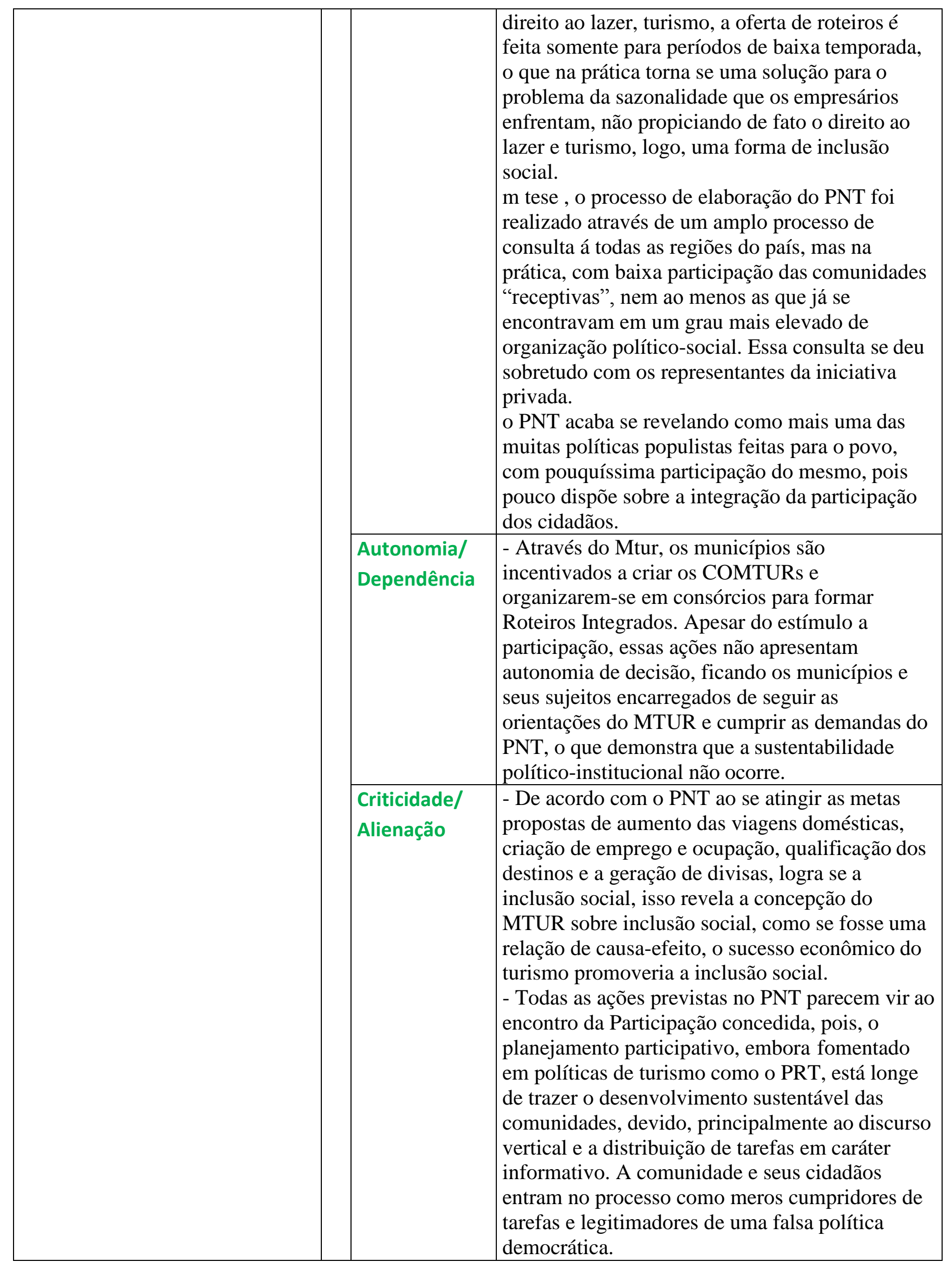




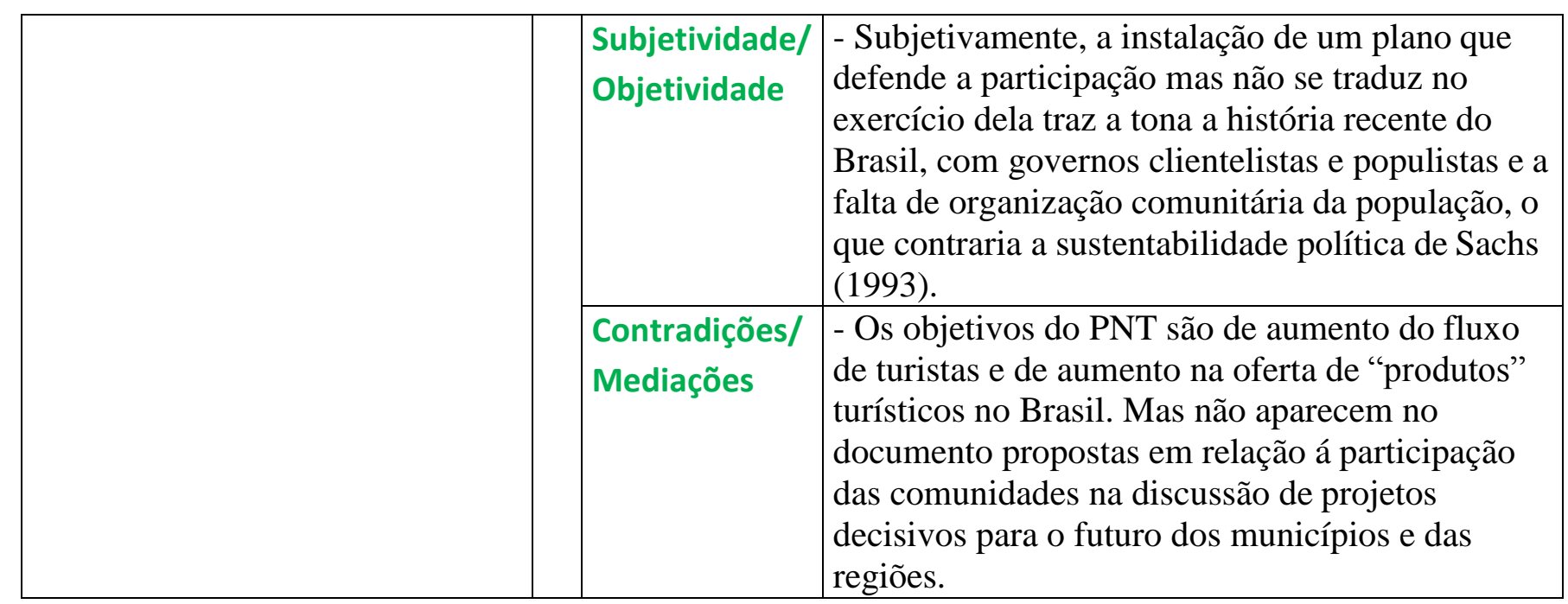


APÊNDICE F- Quadro interpretativo de trechos do discurso do documento: Plano Nacional de Turismo 2013-2016

\begin{tabular}{|c|c|c|c|}
\hline \multicolumn{2}{|l|}{ TEMAS } & & \\
\hline \multirow{7}{*}{$\begin{array}{c}\text { Desenvolvimento } \\
\text { Sustentável e Includente }\end{array}$} & \multirow{3}{*}{$\begin{array}{l}\text { R } \\
\text { U } \\
\text { B } \\
\text { R } \\
\text { I } \\
\text { C } \\
\text { A } \\
\text { S }\end{array}$} & Concepção & $\begin{array}{l}\text { - Reconhecimento de que a sustentabilidade } \\
\text { ocupava uma posição periférica nas proposições } \\
\text { dos PNts anteriores. Porém nesse PNT a } \\
\text { sustentabilidade é focada na dimensão ambiental, } \\
\text { salvo o combate a exploração sexual; a } \\
\text { Integração da produção associada na cadeia } \\
\text { produtiva do turismo, bem como o Fomento ao } \\
\text { turismo de base comunitária entram como } \\
\text { diversificação da oferta. }\end{array}$ \\
\hline & & Dificuldades & $\begin{array}{l}\text { - Compreender a sustentabilidade em sua } \\
\text { totalidade e monitorar os efeitos/ impactos do } \\
\text { turismo contemplando todas as dimensões desta } \\
\text { (ambiental, cultural, político institucional, social } \\
\text { e econômica). A visão do PNT está atrelada a } \\
\text { ganhos econômicos. Sustentabilidade permanece } \\
\text { entrando apenas como uma justificativa para } \\
\text { algumas ações. }\end{array}$ \\
\hline & & Avanços & $\begin{array}{l}\text { - O comprometimento (pelo menos em tese) com } \\
\text { acessibilidade para promover condições para } \\
\text { visitação aos atrativos turísticos com segurança e } \\
\text { autonomia por pessoas com deficiência ou com } \\
\text { mobilidade reduzida ; combate á exploração } \\
\text { sexual. }\end{array}$ \\
\hline & & $\begin{array}{l}\text { Totalidade/ } \\
\text { Fragmentação }\end{array}$ & \\
\hline & & Teoria/Prática & $\begin{array}{l}\text { - Concepção de desenvolvimento que busca em } \\
\text { tese, “a desconcentração de renda por meio da } \\
\text { regionalização, mas na prática, a concentração } \\
\text { de renda pode existir nas próprias localidades. }\end{array}$ \\
\hline & $\mathbf{R}$ & $\begin{array}{l}\text { Autonomia/ } \\
\text { Dependência }\end{array}$ & $\begin{array}{l}\text { - O PNT, traz a dependência do setor privado } \\
\text { para o desenvolvimento do turismo e para a } \\
\text { geração de empregos; demonstra ainda um } \\
\text { quadro de dependência em relação ao fluxo } \\
\text { turístico internacional e nacional para alavancar a } \\
\text { economia, inclusive com o estabelecimento de } \\
\text { metas quantitativas em relação á geração de } \\
\text { emprego, aumento de divisa, de fluxos no } \\
\text { turismo interno e de turistas estrangeiros. }\end{array}$ \\
\hline & A & $\begin{array}{l}\text { Criticidade/ } \\
\text { Alienação }\end{array}$ & $\begin{array}{l}\text { - Embora o plano faça menção á perspectiva em } \\
\text { se planejar o desenvolvimento do turismo } \\
\text { pautado na sustentabilidade, o que é um avanço, }\end{array}$ \\
\hline
\end{tabular}




\begin{tabular}{|c|c|c|c|}
\hline & $S$ & & $\begin{array}{l}\text { há que se ter o cuidado em não só ficar no } \\
\text { discurso, pois a sustentabilidade tem que se } \\
\text { traduzir em ações concretas, objetivas, o que } \\
\text { justamente o plano não traz. }\end{array}$ \\
\hline & & $\begin{array}{l}\text { Subjetividade/ } \\
\text { Objetividade }\end{array}$ & $\begin{array}{l}\text { - Subjetivamente, os autores do PNT apresentam } \\
\text { como pilares de novo padrão de desenvolvimento } \\
\text { o aumento da competitividade do setor, o seu } \\
\text { impacto na melhoria das condições de vida da } \\
\text { população, a descentralização das decisões e o } \\
\text { respeito ao meio ambiente. Mas, objetivamente, } \\
\text { uma melhoria das condições de vida da } \\
\text { população, a tomada de decisões e o respeito ao } \\
\text { meio ambiente estão atrelados ao aumento da } \\
\text { competitividade do setor, estando portanto nas } \\
\text { mãos da iniciativa privada. }\end{array}$ \\
\hline & & $\begin{array}{l}\text { Contradições/ } \\
\text { Mediações }\end{array}$ & $\begin{array}{l}\text { - Embora o componente sustentabilidade apareça } \\
\text { no discurso do PNT, não aparecem no } \\
\text { documento propostas de gerenciamento de } \\
\text { impactos sobre o meio ambiente, cultura, sociais, } \\
\text { territoriais nas comunidades receptivas. Aparece } \\
\text { somente como objetivo a avaliação do impacto da } \\
\text { atividade turística na economia. } \\
\text { - O PNT tem o discurso do desenvolvimento, no } \\
\text { entanto, a maioria dos objetivos estão voltados } \\
\text { para atender aos interesses do capital não só } \\
\text { nacional, mas sobretudo atrair o capital } \\
\text { estrangeiro. }\end{array}$ \\
\hline \multirow[t]{3}{*}{$\begin{array}{c}\text { Turismo e Políticas } \\
\text { Públicas }\end{array}$} & \multirow{3}{*}{$\begin{array}{l}\text { R } \\
\text { U } \\
\text { B } \\
\text { R } \\
\text { I } \\
\text { C } \\
\text { A } \\
\text { S }\end{array}$} & Concepção & $\begin{array}{l}\text { - Concepção de política pública de turismo: Mais } \\
\text { do que nos planos anteriores a política pública } \\
\text { trata o turismo somente pelo aspecto econômico, } \\
\text { nesse PNT é dado relevância á competitividade. } \\
\text { O PNT continua a traduzir -se em ações para a } \\
\text { inserção do Brasil no cenário turístico mundial, } \\
\text { objetivando melhorar o posicionamento no } \\
\text { ranking da competitividade mundial. }\end{array}$ \\
\hline & & Dificuldades & $\begin{array}{l}\text { - Desafio do MTUR - o aperfeiçoamento da } \\
\text { interlocução e qualificação institucional a partir } \\
\text { das unidades federadas com as regiões e os } \\
\text { municípios que compçoiem o mapa da } \\
\text { regionalização. }\end{array}$ \\
\hline & & Avanços & $\begin{array}{l}\text { - Reconhecimento da contribuição que a pesquisa } \\
\text { científica e as universidades podem dar no } \\
\text { delineamento das políticas públicas, para tal } \\
\text { tarefa, existe uma ação para implementar } \\
\text { programa contínuo de fomento público para o } \\
\text { desenvolvimento de pesquisa, inovação e } \\
\text { conhecimento pelos programas de pós-graduação } \\
\text { reconhecidos e recomendados pela CAPES, pelos } \\
\text { institutos sem fins lucrativos e para } \\
\text { empreendimentos privados, }\end{array}$ \\
\hline
\end{tabular}




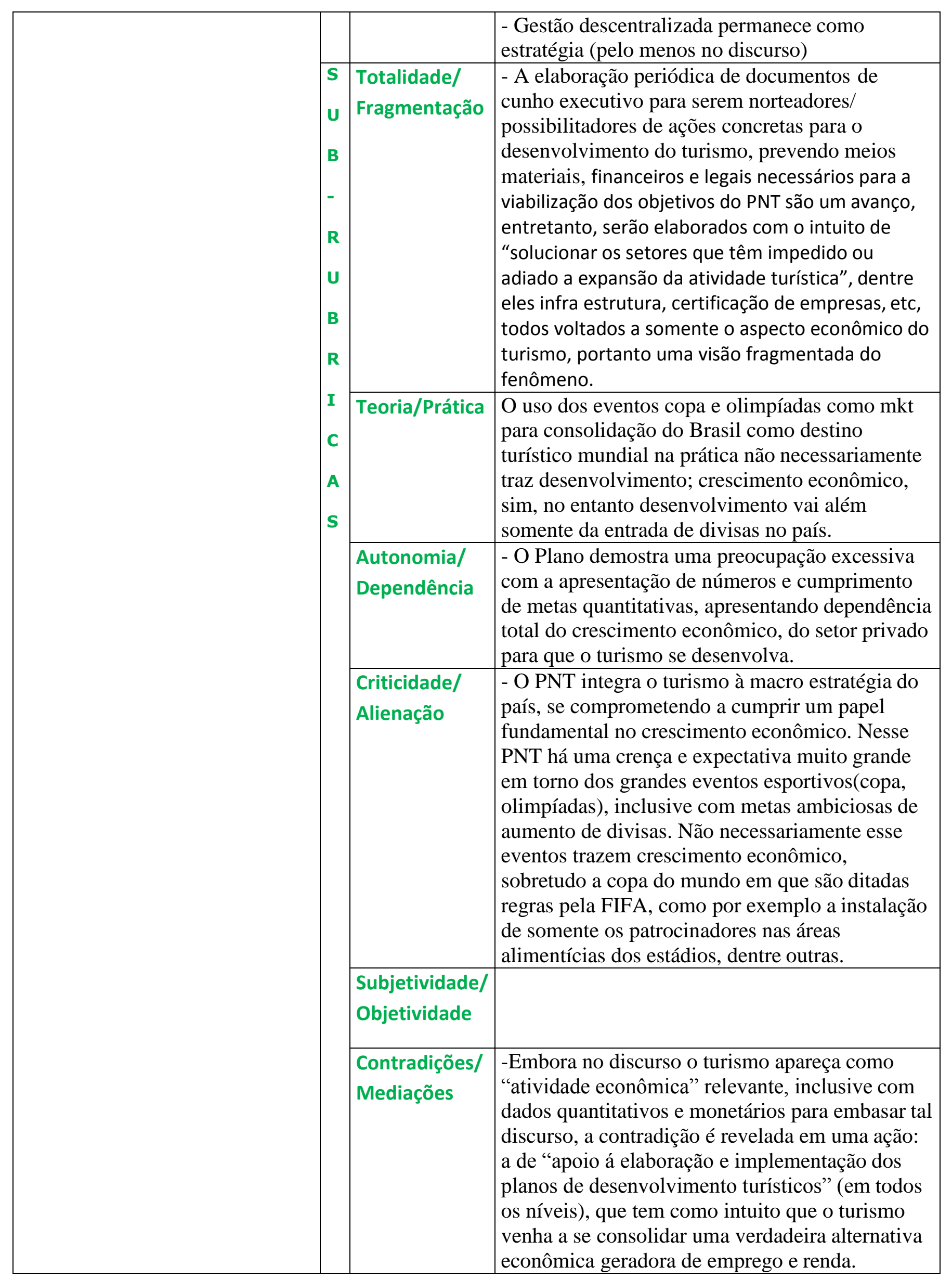




\begin{tabular}{|c|c|c|c|}
\hline \multirow{10}{*}{ Espaço; Território } & \multirow{4}{*}{\begin{tabular}{|l}
$R$ \\
U \\
B \\
R \\
I \\
C \\
A \\
S
\end{tabular}} & Concepção & $\begin{array}{l}\text { - Continuidade do PRT como abordagem } \\
\text { territorial, entretanto neste PNT o objetivo dessa } \\
\text { abordagem é com vistas à competitividade dos } \\
\text { produtos turísticos nas regiões. }\end{array}$ \\
\hline & & Dificuldades & $\begin{array}{l}\text { - Compreender e lidar com as diferenças } \\
\text { territoriais ( que envolvem não só relações } \\
\text { econômicas, mas relações de poder; dinâmica } \\
\text { local/global, relações culturais, relações jurídico- } \\
\text { políticas, meio ambiente naturais diversos). }\end{array}$ \\
\hline & & Avanços & \\
\hline & & & \\
\hline & $\mathbf{U}$ & $\begin{array}{l}\text { Totalidade/ } \\
\text { Fragmentação }\end{array}$ & $\begin{array}{l}\text { - Embora o PNT tenha como proposito } \\
\text { desenvolver o turismo em todo o território } \\
\text { nacional, os objetivos propostos revelam que } \\
\text { somente alguns municípios serão priorizados: } \\
\text { aqueles que apresentam demanda já consolidado } \\
\text { e sobretudo as cidades que serão sede na copa. }\end{array}$ \\
\hline & $\mathbf{R}$ & Teoria/Prática & \\
\hline & $\mathbf{u}$ & $\begin{array}{l}\text { Autonomia/ } \\
\text { Dependência }\end{array}$ & $\begin{array}{l}\text { - O desenvolvimento do turismo de forma } \\
\text { sustentável também depende políticas de } \\
\text { ordenamento e uso do território e o plano não } \\
\text { apresenta nenhuma ação de apoio nesse sentido }\end{array}$ \\
\hline & $\mathbf{S}$ & $\begin{array}{l}\text { Criticidade/ } \\
\text { Alienação }\end{array}$ & $\begin{array}{l}\text { - Enquanto um instrumento de planejamento do } \\
\text { Estado, o PNT também torna se um instrumento } \\
\text { de poder, e como tal o governo o usa na tentativa } \\
\text { de organizar o espaço com vistas ao } \\
\text { desenvolvimento do país, mas também de } \\
\text { subjugá lo á lógica da disseminação da } \\
\text { apropriação capitalista do mesmo, uma vez que a } \\
\text { ênfase toda do Plano está no mercado, com } \\
\text { objetivo de que o turismo atinja todo o território } \\
\text { nacional. }\end{array}$ \\
\hline & & $\begin{array}{l}\text { Subjetividade/ } \\
\text { Objetividade }\end{array}$ & \\
\hline & & $\begin{array}{l}\text { Contradições/ } \\
\text { Mediações }\end{array}$ & \\
\hline & $\mathbf{I}$ & Concepção & $\begin{array}{l}\text { - No PNT existem pouquíssimas referências aos } \\
\text { trabalhadores do turismo, á exceção da } \\
\text { qualificação. Os trabalhadores do turismo são } \\
\text { concebidos enquanto peças de uma engrenagem } \\
\text { maior que é o turismo visto enquanto atividade } \\
\text { econômica; também são concebidos enquanto } \\
\text { consumidores potenciais. } \\
\text { Nesse PNT, a competitividade aparece como um } \\
\text { componente bastante forte em quase todas as }\end{array}$ \\
\hline
\end{tabular}




\section{Relações de Capital/Trabalho}

\begin{tabular}{|c|c|c|}
\hline $\mathbf{S}$ & & $\begin{array}{l}\text { ações propostas, o que revela que mais do que os } \\
\text { planos anteriores, o mercado/capital ganha } \\
\text { relevância, a maioria das ações estão voltadas } \\
\text { para a apropriação quase que total do capital para } \\
\text { o desenvolvimento do turismo. }\end{array}$ \\
\hline & Dificuldades & $\begin{array}{l}\text { - De acordo com o diagnóstico do PNT, as } \\
\text { dificuldades para o desenvolvimento do turismo } \\
\text { por parte setor privado são: o financiamento e a } \\
\text { capitalização do setor, a capacitação técnico- } \\
\text { gerencial, o tratamento fiscal/tributário, a } \\
\text { inovação tecnológica, a promoção interna e } \\
\text { externa, a certificação, o cadastramento, o } \\
\text { desenvolvimento de micro e pequenas empresas } \\
\text { do segmento do turismo. } \\
\text { - Ainda perdura o diagnóstico da deficiência } \\
\text { crônica na gestão e operacionalização de toda } \\
\text { infraestrutura básica (saneamento, água, energia, } \\
\text { transportes) e turística, é uma das dificuldades } \\
\text { diagnosticadas pelo PNT a ser enfrentadas, } \\
\text { sobretudo pela gestão pública, mas que } \\
\text { reverberam e tem implicações no setor privado e } \\
\text { na vida das comunidades que recebem turistas. }\end{array}$ \\
\hline & Avanços & $\begin{array}{l}\text { - Regulamentação, normatização e fiscalização } \\
\text { do setor. }\end{array}$ \\
\hline $\mathbf{U}$ & $\begin{array}{l}\text { Totalidade/ } \\
\text { Fragmentação }\end{array}$ & $\begin{array}{l}\text { Embora o Pnt tenha como meta aumentar } \\
\text { para 3,6 milhões as ocupações formais no } \\
\text { setor de turismo até 2016, o plano não traz } \\
\text { preocupação alguma em relação ás condições } \\
\text { dessas, a regulamentação dessas ocupações, etc }\end{array}$ \\
\hline $\mathbf{s}$ & Teoria/Prática & $\begin{array}{l}\text { Embora a Classificação e certificação dos } \\
\text { serviços e equipamentos turísticos tenha em tese } \\
\text { o compromisso com a qualificação, na prática a } \\
\text { ideia é de melhorar a competitividade do turismo } \\
\text { nacional, não fica claro no PNT que o intuito } \\
\text { seja com a melhoria dos serviços ao turista. } \\
\text { - O PNT faz referência á integração da produção } \\
\text { associada na cadeia produtiva do turismo } \\
\text { entretanto, essas ações não visão o } \\
\text { desenvolvimento dessas atividades, mas sim que } \\
\text { elas sirvam para contribuir com a diversificação } \\
\text { da oferta turística que consequentemente tem } \\
\text { impactos positivos na competitividade. } \\
\text { Embora em tese no PNT a qualificação dos } \\
\text { trabalhadores, bem como a oferta de crédito para } \\
\text { os empreendedores sejam estratégias capazes de } \\
\text { gerar mais novos empregos no turismo, na prática } \\
\text { não são a garantia de que realmente serão } \\
\text { gerados e sobretudo na atividade turística; } \\
\text { Ademais o trabalhador pode ser qualificado para }\end{array}$ \\
\hline
\end{tabular}




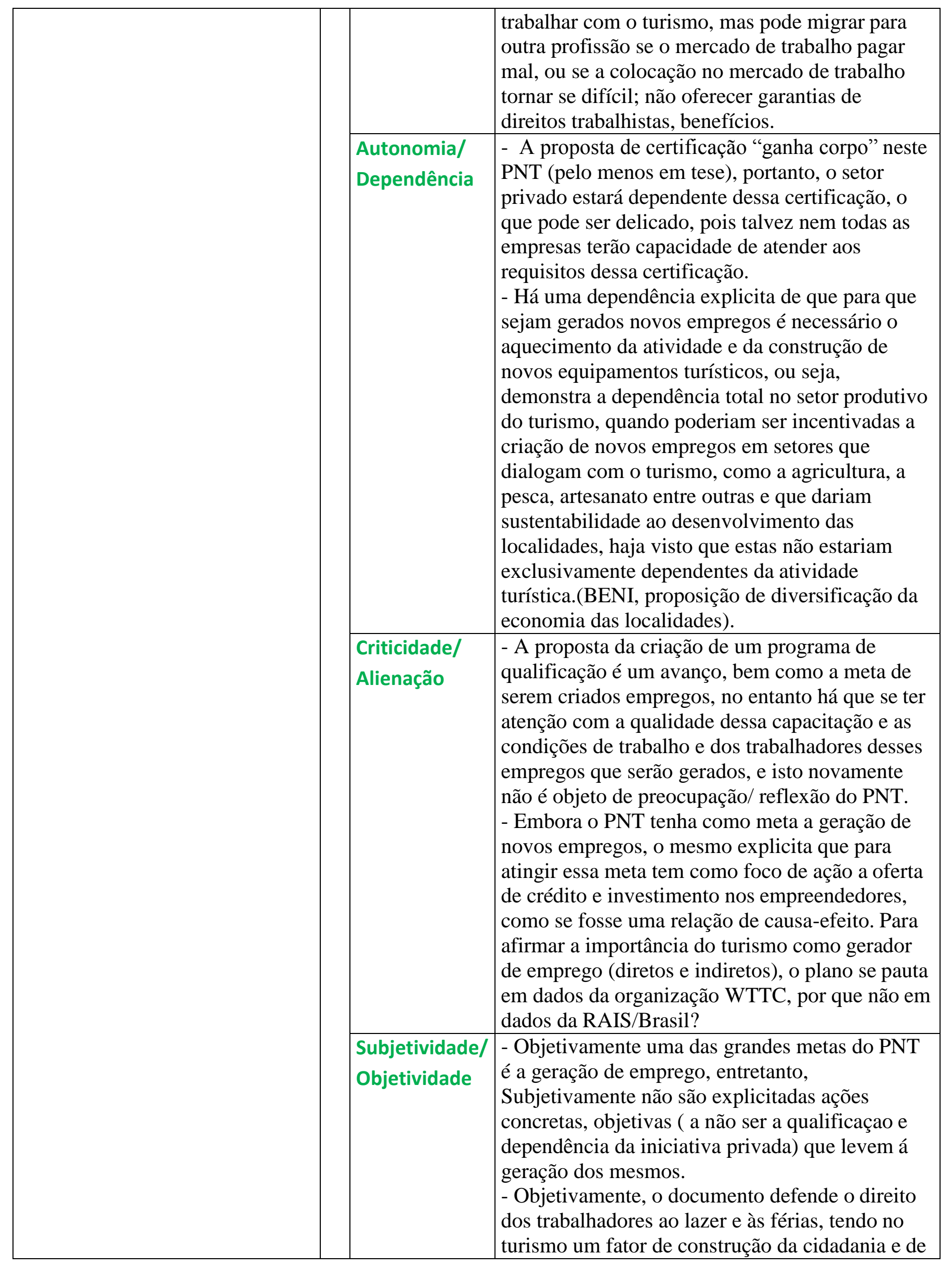




\begin{tabular}{|c|c|c|}
\hline & & $\begin{array}{l}\text { integração social. Mas subjetivamente, o que se } \\
\text { deseja é a ampliação do mercado consumidor do } \\
\text { turismo no Brasil com vistas a resolver o } \\
\text { problema da sazonalidade. }\end{array}$ \\
\hline & $\begin{array}{l}\text { Contradições/ } \\
\text { Mediações }\end{array}$ & $\begin{array}{l}\text { Continua a visão sobre o turismo enquanto } \\
\text { atividade econômica necessitar de menor } \\
\text { investimento na qualificação das pessoas e na } \\
\text { geração de postos de trabalho; a ideia de se } \\
\text { investir o mínimo possível nas pessoas e na área, } \\
\text { contradiz o discurso onde o turismo seria uma } \\
\text { prioridade do Governo. A criação de } \\
\text { oportunidades de emprego, favorece os jovens e } \\
\text { os beneficiários dos programas sociais, o que passa } \\
\text { a ideia de que as atividades envolvidas no turismo } \\
\text { não necessitam de muita qualificação }\end{array}$ \\
\hline \multirow[t]{4}{*}{ Cidadania } & Concepção & $\begin{array}{l}\text { - O plano pouco faz menção á cidadania e a } \\
\text { cidadãos, a única proposição é o incentivo (em } \\
\text { tese) á participação comunitária nos processos de } \\
\text { planejamento e gestão do turismo, além de } \\
\text { compreender cidadãos enquanto possíveis } \\
\text { consumidores. }\end{array}$ \\
\hline & Dificuldades & $\begin{array}{l}\text { - A principal dificuldade está na real valorização } \\
\text { da participação e dos conhecimentos locais para a } \\
\text { gestão do turismo. Devido ao processo } \\
\text { democrático ser recente no país e a democracia } \\
\text { estar ainda por se consolidar, a prática do } \\
\text { processo participativo não tem tradição, ela ainda } \\
\text { é incipiente. Existe também a dificuldade em } \\
\text { conseguir promover o diálogo e participação do } \\
\text { país como um todo, pois devido ás dimensões } \\
\text { continentais, a dificuldade do processo de } \\
\text { interlocução se faz presente, requerendo a criação } \\
\text { de mecanismos eficazes para que esse processo } \\
\text { ocorra. }\end{array}$ \\
\hline & Avanços & $\begin{array}{l}\text { fortalecer a gestão descentralizada do turismo no } \\
\text { Brasil, a partir da articulação dos entes que } \\
\text { integram o Sistema Nacional de Turismo, na } \\
\text { representatividade das três esferas de governo, a } \\
\text { iniciativa privada e o terceiro setor, entendida } \\
\text { como uma estratégia necessária para implementar } \\
\text { a política e o Plano Nacional de Turismo. }\end{array}$ \\
\hline & $\begin{array}{l}\text { Totalidade/ } \\
\text { Fragmentação }\end{array}$ & $\begin{array}{l}\text { - A totalidade em relação ao processo de } \\
\text { desenvolvimento do turismo, seria a máxima } \\
\text { participação possível de todos os envolvidos com } \\
\text { o turismo no que tange ao planejamento e gestão: } \\
\text { poder público/iniciativa privada/comunidade. } \\
\text { Entretanto, como o PNT foi instalado a partir da } \\
\text { consulta aos pares, sobretudo da iniciativa } \\
\text { privada, fragmentou se a visão do turismo } \\
\text { reduzindo o enquanto negócio, portanto }\end{array}$ \\
\hline
\end{tabular}




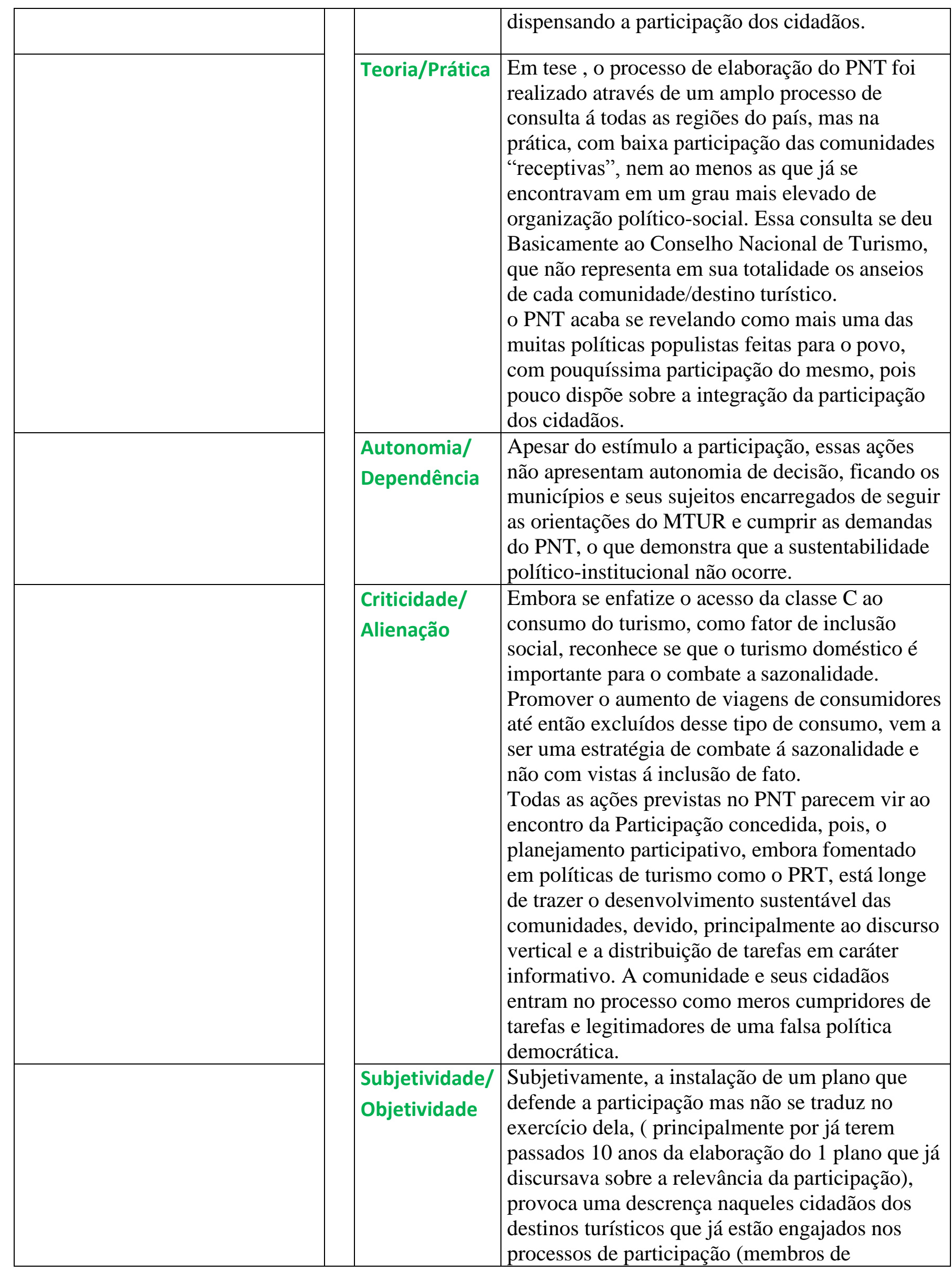




\begin{tabular}{|l|l|l|}
\hline & & $\begin{array}{l}\text { COMTURs, Fóruns) além de criar um ambiente } \\
\text { desestimulador aqueles que desejem participar. }\end{array}$ \\
\cline { 2 - 3 } & $\begin{array}{l}\text { Contradições/ } \\
\text { Mediações }\end{array}$ & $\begin{array}{l}\text { Não aparecem no documento propostas em } \\
\text { relação á participação das comunidades na } \\
\text { discussão de projetos decisivos para o futuro dos } \\
\text { municípios e das regiões. }\end{array}$ \\
\hline
\end{tabular}




\section{APÊNDICE G - Quadro interpretativo de trechos do discurso do documento:}

\section{Plano Municipal de Turismo de Pirenópolis 2012-2016}

\begin{tabular}{|c|c|c|c|}
\hline \multicolumn{2}{|l|}{ TEMAS } & & \\
\hline \multirow{5}{*}{$\begin{array}{c}\text { Desenvolvimento } \\
\text { Sustentável e Includente }\end{array}$} & \multirow{3}{*}{$\begin{array}{l}\text { R } \\
\text { U } \\
\text { B } \\
\text { R } \\
\text { I } \\
\text { C } \\
\text { A } \\
\text { S }\end{array}$} & Concepção & $\begin{array}{l}\text { Embora o plano mencione por diversas vezes o } \\
\text { termo sustentabilidade, não aparece uma } \\
\text { concepção clara do que vem a ser esta. } \\
\text { Analisando as ações propostas, fica evidente que } \\
\text { sustentabilidade é mais entendida em seu aspecto } \\
\text { ambiental e cultural. } \\
\text { O plano está comprometido com a } \\
\text { competitividade do "destino turístico" e não com } \\
\text { o desenvolvimento do município pelo turismo. }\end{array}$ \\
\hline & & Dificuldades & $\begin{array}{l}\text { O plano define alguns "fatores críticos para o } \\
\text { sucesso" para o alcance dos objetivos definidos } \\
\text { no plano, e dentre eles estão: Articulação e } \\
\text { integração entre as entidades representativas do } \\
\text { setor turístico e poder público. Arranjo da cadeia } \\
\text { produtiva do turismo para comercialização do } \\
\text { destino. Políticas públicas específicas para o setor } \\
\text { turístico. Preservação e valorização da cultura e } \\
\text { artesanato local. Preservação e valorização do meio } \\
\text { ambiente. Infraestrutura básica eficiente que } \\
\text { garanta o atendimento das necessidades da } \\
\text { comunidade e dos turistas. Sensibilização da } \\
\text { comunidade sobre a importância da atividade } \\
\text { turística para o desenvolvimento do município. } \\
\text { Segurança pública eficiente que garanta a } \\
\text { tranquilidade e integridade física do turista e } \\
\text { qualidade de vida para os moradores. Saúde pública } \\
\text { eficiente que garanta o atendimento das } \\
\text { peçessidades da comunidade e dos turistas. } \\
\text { Trânsito ordenado no centro histórico. }\end{array}$ \\
\hline & & Avanços & $\begin{array}{l}\text { O plano tem como uma de suas ações o } \\
\text { Desenvolvimento de programa de educação } \\
\text { patrimonial e ambiental nas escolas }\end{array}$ \\
\hline & B & $\begin{array}{l}\text { Totalidade/ } \\
\text { Fragmentação }\end{array}$ & $\begin{array}{l}\text { A totalidade do desenvolvimento sustentável, } \\
\text { seria considerar todas as suas dimensões, } \\
\text { entretanto o plano traz uma concepção além de } \\
\text { frágil, fragmentada pois as poucas ações que } \\
\text { tratam de sustentabilidade, aparecem sob a } \\
\text { perspectiva cultural e ambiental. }\end{array}$ \\
\hline & $\mathbf{R}$ & Teoria/Prática & $\begin{array}{l}\text { Em tese o plano traz a "missão" de "Desenvolver } \\
\text { o turismo de forma sustentável em suas três } \\
\text { dimensões: ambiental, econômica e social, e, } \\
\text { subsidiar políticas públicas para o setor, a fim de } \\
\text { proporcionar qualidade de vida e renda aos } \\
\text { moradores, satisfação dos visitantes e preservação } \\
\text { do patrimônio cultural e natural", na prática essa }\end{array}$ \\
\hline
\end{tabular}




\begin{tabular}{|c|c|c|c|}
\hline & $\begin{array}{l}\text { I } \\
\text { C } \\
\text { A }\end{array}$ & & $\begin{array}{l}\text { sustentabilidade se traduz em poucas ações (que } \\
\text { evidenciam a dimensão cultural e ambiental do } \\
\text { desenvolvimento sustentável), que não condizem } \\
\text { com um planejamento integral do turismo }\end{array}$ \\
\hline & $\mathbf{s}$ & $\begin{array}{l}\text { Autonomia/ } \\
\text { Dependência }\end{array}$ & $\begin{array}{l}\text { O plano evidencia uma dependência quase que } \\
\text { total tanto da iniciativa privada, quando do } \\
\text { próprio poder público ( em termos de serviços de } \\
\text { saúde e segurança pública, e, estabelecimento de } \\
\text { políticas específicas para o turismo) para o } \\
\text { desenvolvimento do turismo. }\end{array}$ \\
\hline & & $\begin{array}{l}\text { Criticidade/ } \\
\text { Alienação }\end{array}$ & $\begin{array}{l}\text { Embora o Plano traga em seu discurso a palavra } \\
\text { "sustentabilidade", esta se apresenta vazia de } \\
\text { sentido, de uma concepção clara. Além disso, } \\
\text { maioria das ações estão voltadas para o aspecto } \\
\text { econômico do turismo, para atender a iniciativa } \\
\text { privada. }\end{array}$ \\
\hline & & $\begin{array}{l}\text { Subjetividade/ } \\
\text { Objetividade }\end{array}$ & \\
\hline & & $\begin{array}{l}\text { Contradições/ } \\
\text { Mediações }\end{array}$ & \\
\hline \multirow{7}{*}{$\begin{array}{l}\text { Turismo e Políticas } \\
\text { Públicas }\end{array}$} & \multirow{3}{*}{$\begin{array}{l}\text { R } \\
\text { U } \\
\text { B } \\
\text { R } \\
\text { I } \\
\text { C } \\
\text { A } \\
\text { S }\end{array}$} & Concepção & $\begin{array}{l}\text { Concepção de turismo reducionista: entendido } \\
\text { enquanto atividade econômica geradora de } \\
\text { emprego e renda. No plano, o turismo é } \\
\text { concebido enquanto "importante instrumento } \\
\text { transformador da economia local" }\end{array}$ \\
\hline & & Dificuldades & $\begin{array}{l}\text { De acordo com o plano: "políticas públicas } \\
\text { específicas para o setor turístico" é um "fator } \\
\text { crítico de sucesso". }\end{array}$ \\
\hline & & Avanços & $\begin{array}{l}\text { Elaborar um plano municipal de turismo, vem a } \\
\text { ser um avanço para o município. }\end{array}$ \\
\hline & \multirow{4}{*}{$\begin{array}{l}\text { S } \\
\text { U } \\
\text { B } \\
- \\
\text { R } \\
\text { U } \\
\text { B }\end{array}$} & $\begin{array}{l}\text { Totalidade/ } \\
\text { Fragmentação }\end{array}$ & $\begin{array}{l}\text { A contemplação de diversos aspectos que } \\
\text { envolvem o fenômeno turismo seria a totalidade } \\
\text { que a política pública/planejamento deveria } \\
\text { abordar, no entanto o plano se ocupa somente de } \\
\text { alguns aspectos. }\end{array}$ \\
\hline & & Teoria/Prática & $\begin{array}{l}\text { Em tese, o plano traz a "missão" de "desenvolver } \\
\text { o turismo de forma sustentável", no entanto, na } \\
\text { prática as ações não se traduzem nesta. }\end{array}$ \\
\hline & & $\begin{array}{l}\text { Autonomia/ } \\
\text { Dependência }\end{array}$ & \\
\hline & & $\begin{array}{l}\text { Criticidade/ } \\
\text { Alienação }\end{array}$ & $\begin{array}{l}\text { O plano é desconexo e apresenta ações } \\
\text { desarticuladas umas das outras e diversas } \\
\text { contradições no próprio discurso e eções. O }\end{array}$ \\
\hline
\end{tabular}




\begin{tabular}{|c|c|c|c|}
\hline & I & & $\begin{array}{l}\text { mais se assemelha a um inventário ou } \\
\text { diagnóstico de turismo do município, com a } \\
\text { enumeração de algumas ações. }\end{array}$ \\
\hline & A & $\begin{array}{l}\text { Subjetividade/ } \\
\text { Objetividade }\end{array}$ & \\
\hline & & $\begin{array}{l}\text { Contradições/ } \\
\text { Mediações }\end{array}$ & $\begin{array}{l}\text { Embora o plano em seu discurso traga a ideia de } \\
\text { que o processo de elaboração do mesmo foi } \\
\text { participativo contraditoriamente ele revela que } \\
\text { foram } 20 \text { pessoas que participaram da elaboração } \\
6 \text { dentre estas da gestão pública, e o restante do } \\
\text { trade. }\end{array}$ \\
\hline \multirow{9}{*}{ Espaço; Território } & \multirow{3}{*}{$\begin{array}{l}\mathrm{R} \\
\mathrm{U} \\
\mathrm{B} \\
\mathrm{R} \\
\mathrm{I} \\
\mathrm{C} \\
\end{array}$} & Concepção & $\begin{array}{l}\text { Espaço; território pouco são tratados no plano, } \\
\text { sendo concebidos como recursos para a } \\
\text { "atividade turística". O espaço rural aparece } \\
\text { como recurso/ potencial para desenvolvimento do } \\
\text { turismo. }\end{array}$ \\
\hline & & Dificuldades & \\
\hline & & & \\
\hline & A & Avanços & $\begin{array}{l}\text { A proposição de ações de preservação nos } \\
\text { espaços de meio ambiente natural é um avanço. }\end{array}$ \\
\hline & $\begin{array}{l}S \\
\mathrm{U} \\
\mathrm{B}\end{array}$ & $\begin{array}{l}\text { Totalidade/ } \\
\text { Fragmentação }\end{array}$ & $\begin{array}{l}\text { A totalidade seria pensar o turismo e seus efeitos } \\
\text { em todo o município, no entanto, o plano escolhe } \\
\text { alguns espaços e territórios do município para tal } \\
\text { tarefa. }\end{array}$ \\
\hline & - & Teoria/Prática & \\
\hline & $\begin{array}{l}\mathbf{R} \\
\mathbf{U}\end{array}$ & $\begin{array}{l}\text { Autonomia/ } \\
\text { Dependência }\end{array}$ & \\
\hline & $\begin{array}{l}\text { B } \\
\text { R } \\
\text { I } \\
\text { C } \\
\text { A } \\
\text { S }\end{array}$ & $\begin{array}{l}\text { Criticidade/ } \\
\text { Alienação }\end{array}$ & $\begin{array}{l}\text { - Enquanto um instrumento de planejamento do } \\
\text { Município, o PMT também torna se também um } \\
\text { instrumento de poder, e como tal o poder público } \\
\text { o usa na tentativa de organizar o espaço com } \\
\text { vistas ao desenvolvimento do município, mas } \\
\text { também de subjugá lo á lógica da disseminação } \\
\text { da apropriação capitalista do mesmo. Embora o } \\
\text { plano traga a perspectiva da preservação com o } \\
\text { meio ambiente natural e a cultura local (inclusive } \\
\text { com a proposição de ações neste sentido), a } \\
\text { maior parte das ações tem ênfase no atendimento } \\
\text { das necessidades do mercado }\end{array}$ \\
\hline & & $\begin{array}{l}\text { Subjetividade/ } \\
\text { Objetividade }\end{array}$ & \\
\hline
\end{tabular}




\begin{tabular}{|c|c|c|c|}
\hline & & $\begin{array}{l}\text { Contradições/ } \\
\text { Mediações }\end{array}$ & \\
\hline \multirow{7}{*}{$\begin{array}{c}\text { Relações de } \\
\text { Capital/Trabalho }\end{array}$} & \multirow[t]{3}{*}{$\begin{array}{l}\text { R } \\
\text { U } \\
\text { B } \\
\text { R } \\
\text { I } \\
\text { C } \\
\text { A } \\
\text { S }\end{array}$} & Concepção & $\begin{array}{l}\text { - No Plano a iniciativa privada é vista como } \\
\text { fundamental parceiro para o desenvolvimento do } \\
\text { turismo, inclusive na elaboração deste. } \\
\text { - Apenas duas ações são direcionadas aos } \\
\text { trabalhadores: são ações de qualificação. Cabe } \\
\text { ressaltar que a maioria das ações de qualificação } \\
\text { estão centradas na qualificação de } \\
\text { empreendedores. } \\
\text { - A maioria das ações propostas (dentre todos os } \\
\text { objetivos elencados pelo plano), estão voltadas ao } \\
\text { atendimento das "necessidades" das empresas. } \\
\text { Talvez isso se deva a ter sido o SEBRAE o } \\
\text { orientador do processo “participativo" de } \\
\text { elaboração e formatação do plano. }\end{array}$ \\
\hline & & Dificuldades & $\begin{array}{l}\text { Dificuldade em reconhecer que os trabalhadores } \\
\text { do turismo são fundamentais para que o turismo } \\
\text { aconteça na localidade, e não só a iniciativa } \\
\text { privada. } \\
\text { Falta de conhecimento e habilidades empresariais } \\
\text { de grande parcela dos empreendedores. }\end{array}$ \\
\hline & & Avanços & $\begin{array}{l}\text { Colocar em prática a lei de formalização das } \\
\text { atividades turísticas. }\end{array}$ \\
\hline & \multirow[t]{4}{*}{$\begin{array}{l}\text { S } \\
\text { U } \\
\text { B } \\
\text { R }\end{array}$} & $\begin{array}{l}\text { Totalidade/ } \\
\text { Fragmentação }\end{array}$ & $\begin{array}{l}\text { A totalidade do plano deveria se traduzir em } \\
\text { ações direcionadas não só aos empreendedores } \\
\text { mas aos trabalhadores também, no entanto, o } \\
\text { plano revela a concepção fragmentada do } \\
\text { fenômeno, em que o capital propriamente é que } \\
\text { propicia o "crescimento do turismo". }\end{array}$ \\
\hline & & Teoria/Prática & $\begin{array}{l}\text { Embora o plano tenha como parte de sua missão } \\
\text { "proporcionar qualidade de vida e renda aos } \\
\text { moradores", na prática, a informalidade da maior } \\
\text { parte dos equipamentos turísticos ( detectadas no } \\
\text { diagnóstico do plano), pode até propiciar renda, mas } \\
\text { não necessariamente pode auxiliar na qualidade de } \\
\text { vida dos moradores, uma vez que "qualidade de vida" } \\
\text { está também atrelada a condições decentes de } \\
\text { trabalho. }\end{array}$ \\
\hline & & $\begin{array}{l}\text { Autonomia/ } \\
\text { Dependência }\end{array}$ & \\
\hline & & $\begin{array}{l}\text { Criticidade/ } \\
\text { Alienação }\end{array}$ & $\begin{array}{l}\text { A Informalidade da maior parte empreendedores } \\
\text { turísticos leva necessariamente á informalidade } \\
\text { dos trabalhadores, já que a empresa não } \\
\text { formalizada não pode registrar seus trabalhadores, }\end{array}$ \\
\hline
\end{tabular}




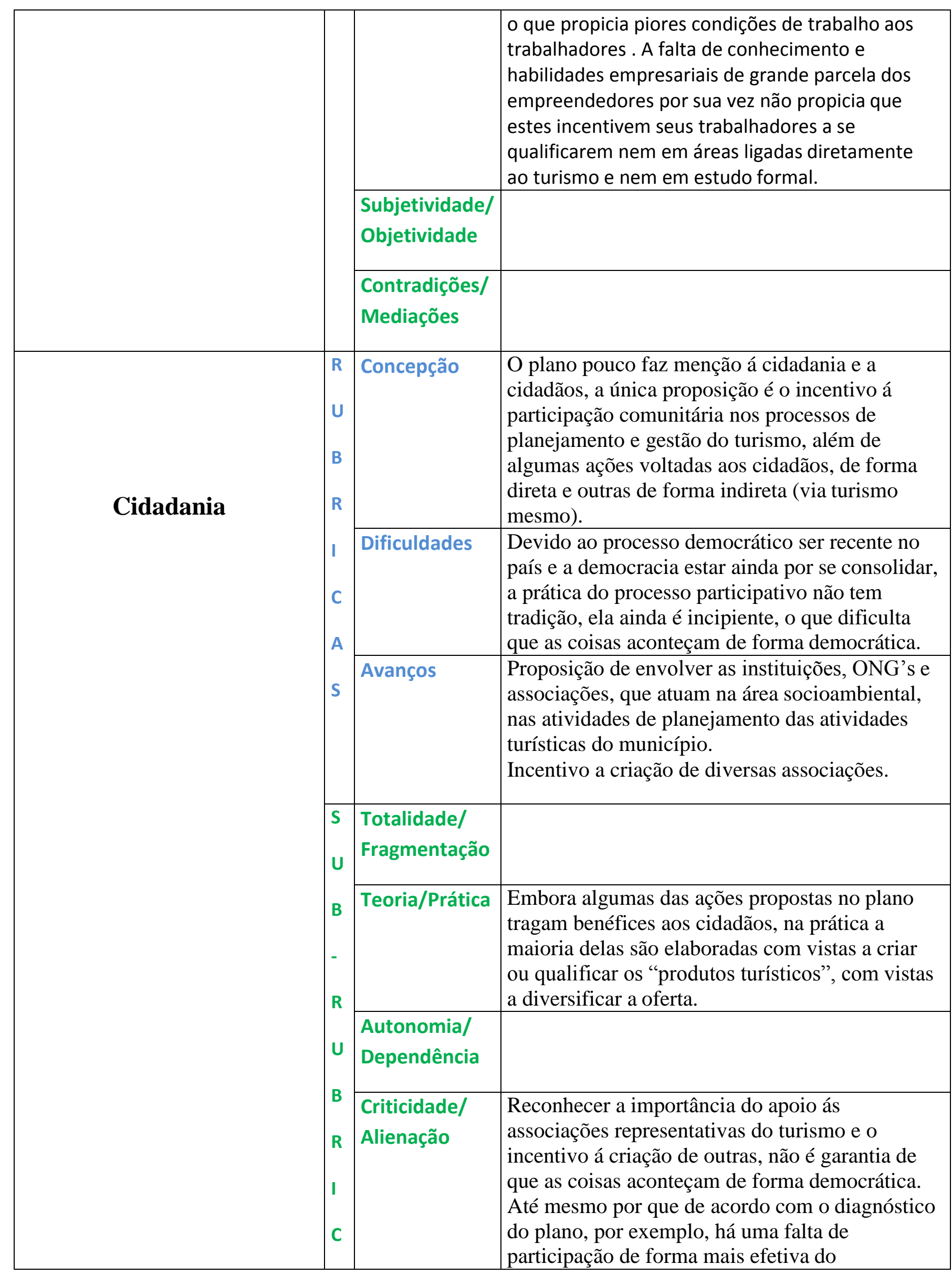




\begin{tabular}{|c|c|c|c|}
\hline & \multirow{3}{*}{$\begin{array}{l}\text { A } \\
\text { S }\end{array}$} & & $\begin{array}{l}\text { empresariado junto às entidades representativas } \\
\text { do turismo. }\end{array}$ \\
\hline & & $\begin{array}{l}\text { Subjetividade/ } \\
\text { Objetividade }\end{array}$ & $\begin{array}{l}\text { Objetivamente a criação e o apoio a associações } \\
\text { pode ser uma ação interessante com vistas ao } \\
\text { processo participativo na gestão do turismo, no } \\
\text { entanto, subjetivamente quando elas não } \\
\text { cumprem o seu papel, podem tornar se apenas } \\
\text { legitimadoras de discursos políticos. }\end{array}$ \\
\hline & & $\begin{array}{l}\text { Contradições/ } \\
\text { Mediações }\end{array}$ & $\begin{array}{l}\text { Embora o plano mencione que o processo de sua } \\
\text { elaboração tenha sido participativo, } \\
\text { contraditoriamente pode se depreender através de } \\
\text { análise e do conhecimento da pesquisadora que } \\
\text { foram poucas pessoas que participaram e a } \\
\text { maioria proveniente do trade turístico. }\end{array}$ \\
\hline
\end{tabular}

O Plano Municipal de Turismo de Pirenópolis se apresenta mais como uma compilação de resultados de estudos, pesquisas, desenvolvido por diversas instituições ao longo dos últimos 10 anos e que tem foco sobretudo na faceta econômica do turismo; apresenta ainda um diagnóstico da "atividade" e faz um apanhado da história do município. O Plano se assemelha mais a um diagnóstico do que a um plano propriamente dito, apresenta diversos erros, contradições entre o diagnóstico e as ações propostas, não dispõe de metas, não estabelece parcerias para a realização das ações A maioria das ações estão voltadas a atender as necessidades do "setor" ou seja da iniciativa privada, fato em partes compreensível, haja visto que foi o SEBRAE que orientou metodologicamente e elaborou o plano, com o apoio da gestão municipal e participação majoritária de pessoas do trade turístico. 
APÊNDICE H - Quadro interpretativo de trechos do discurso do documento:

Plano Diretor de Pirenópolis - 2002.

\begin{tabular}{|c|c|c|c|}
\hline \multicolumn{2}{|l|}{ TEMAS } & & \\
\hline \multirow{9}{*}{$\begin{array}{c}\text { Desenvolvimento } \\
\text { Sustentável e Includente }\end{array}$} & \multirow{3}{*}{$\begin{array}{l}\text { R } \\
\text { U } \\
\text { B } \\
\text { R } \\
\text { I } \\
\text { C } \\
\text { A } \\
\text { S }\end{array}$} & Concepção & $\begin{array}{l}\text { O plano se define como o instrumento básico } \\
\text { para ordenar o desenvolvimento físico-territorial } \\
\text {, compatibilizando-o com a preservação do meio } \\
\text { ambiente, do patrimônio histórico e com o } \\
\text { desenvolvimento econômico, trazendo assim a } \\
\text { perspectiva da sustentabilidade, tanto que a } \\
\text { primeira parte do plano é dedicada ao tratamento } \\
\text { da sustentabilidade da cidade. }\end{array}$ \\
\hline & & Dificuldades & $\begin{array}{l}\text { Colocar na prática todos os projetos que estão } \\
\text { propostos no plano. }\end{array}$ \\
\hline & & Avanços & $\begin{array}{l}\text { Trazer a perspectiva pelo menos em tese da } \\
\text { sustentabilidade já é um avanço em um plano } \\
\text { diretor. No entanto não pode ser só no discurso }\end{array}$ \\
\hline & \multirow[t]{6}{*}{\begin{tabular}{|l} 
S \\
U \\
B \\
- \\
R \\
U \\
B \\
R
\end{tabular}} & $\begin{array}{l}\text { Totalidade/ } \\
\text { Fragmentação }\end{array}$ & $\begin{array}{l}\text { Embora em linhas gerais o plano tenha a } \\
\text { perspectiva da sustentabilidade, fica explícito ao } \\
\text { longo do documento que ela é entendida muito } \\
\text { mais na perspectiva econômica e ambiental, } \\
\text { poucas são as orientações sobre a dimensão } \\
\text { social (embora traga o compromisso de um } \\
\text { programa de geração de emprego e renda por } \\
\text { meio do turismo, mineração e artesanato, outras } \\
\text { questões pouco são abordadas), e, política ( no } \\
\text { que tange á participação da comunidade em } \\
\text { projetos, ações, enfim no ordenamento). }\end{array}$ \\
\hline & & Teoria/Prática & \\
\hline & & $\begin{array}{l}\text { Autonomia/ } \\
\text { Dependência }\end{array}$ & \\
\hline & & $\begin{array}{l}\text { Criticidade/ } \\
\text { Alienação }\end{array}$ & \\
\hline & & $\begin{array}{l}\text { Subjetividade/ } \\
\text { Objetividade }\end{array}$ & \\
\hline & & $\begin{array}{l}\text { Contradições/ } \\
\text { Mediações }\end{array}$ & \\
\hline & $\mathbf{R}$ & Concepção & $\begin{array}{l}\text { O desenvolvimento do turismo (enquanto } \\
\text { atividade econômica), tem como objetivo a } \\
\text { geração de emprego e renda (capítulo II) }\end{array}$ \\
\hline
\end{tabular}




\begin{tabular}{|c|c|c|c|}
\hline \multirow[t]{8}{*}{$\begin{array}{c}\text { Turismo e Políticas } \\
\text { Públicas }\end{array}$} & \multirow{2}{*}{\begin{tabular}{l|l} 
\\
B \\
R \\
I \\
C \\
A \\
S
\end{tabular}} & Dificuldades & $\begin{array}{l}\text { Implementar todos os projetos propostos, no que } \\
\text { tange ao patrimônio histórico-cultural material ( } \\
\text { valorização dos largos e becos, campo das } \\
\text { cavalhadas, entradas da cidade mercado } \\
\text { municipal, criação do centro da memória de } \\
\text { Pirenópolis). }\end{array}$ \\
\hline & & Avanços & $\begin{array}{l}\text { Ter uma seção dedicada ao ordenamento do } \\
\text { turismo pode ser um avanço do plano, no entanto } \\
\text { tem que ser visto com cautela, pois ele deve } \\
\text { atender não só ás anseios do turista, mas } \\
\text { igualmente aos anseios do cidadão. }\end{array}$ \\
\hline & $\begin{array}{l}\text { S } \\
\text { U } \\
\text { B } \\
- \\
\text { R } \\
\text { U } \\
\text { B } \\
\text { R }\end{array}$ & $\begin{array}{l}\text { Totalidade/ } \\
\text { Fragmentação }\end{array}$ & $\begin{array}{l}\text { Embora o plano traga que as ações de promoção } \\
\text { do desenvolvimento das atividades do turismo } \\
\text { devem atender as diretrizes de intervenção quanto } \\
\text { ao turismo histórico e cultural e ao } \\
\text { ecoturismo (portanto a segmentação de acordo } \\
\text { com as potencialidades do município), estes dois } \\
\text { segmentos são entendidos como alternativa de } \\
\text { desenvolvimento econômico, não há por exemplo } \\
\text { proposição de projetos/ações voltados a educação } \\
\text { ambiental, patrimonial, nem projetos de avaliação } \\
\text { de impacto ambientais e culturais da atividade } \\
\text { turística. }\end{array}$ \\
\hline & $\begin{array}{l}\text { I } \\
\text { C } \\
\text { A }\end{array}$ & Teoria/Prática & $\begin{array}{l}\text { O plano traz a proposta da criação de um espaço } \\
\text { físico que integre diversas edificações culturais para a } \\
\text { concentração de atividades e eventos culturais. O } \\
\text { espaço foi construído, no entanto na prática é } \\
\text { subutilizado. Praticamente é usado para eventos que } \\
\text { não são criados "com" e "para" os cidadãos mas sim } \\
\text { por instituições e pessoas que trazem seus eventos } \\
\text { para a cidade, como festival gastronômico, slow film, } \\
\text { etc. Não há uma proposição de incentivo a } \\
\text { comunidade para se apropriar desse espaço. }\end{array}$ \\
\hline & & $\begin{array}{l}\text { Autonomia/ } \\
\text { Dependência }\end{array}$ & \\
\hline & & $\begin{array}{l}\text { Criticidade/ } \\
\text { Alienação }\end{array}$ & $\begin{array}{l}\text { Turismo encarado como o grande salvador das } \\
\text { mazelas sociais (via geração de emprego e renda) } \\
\text {. Embora o plano traga o fomento á atividade } \\
\text { mineradora de quartzito e também do artesanato, } \\
\text { as ações/projetos e impactos dessas demais } \\
\text { atividades pouco são tratados pelo plano. }\end{array}$ \\
\hline & & $\begin{array}{l}\text { Subjetividade/ } \\
\text { Objetividade }\end{array}$ & \\
\hline & & $\begin{array}{l}\text { Contradições/ } \\
\text { Mediações }\end{array}$ & $\begin{array}{l}\text { Embora o plano diretor deva ser em tese um } \\
\text { instrumento de ordenação do município como um } \\
\text { todo, este plano de Pirenópolis elege apenas } \\
\text { algumas áreas (no que tange ao desenvolvimento } \\
\text { do turismo) da cidade além de não trazer }\end{array}$ \\
\hline
\end{tabular}




\begin{tabular}{|c|c|c|c|}
\hline & & & $\begin{array}{l}\text { nenhuma ação em relação aos povoados que } \\
\text { compõem o município, como caxambu, } \\
\text { lagolândia, etc. A única proposição que o plano } \\
\text { traz é que o desenvolvimento do ecoturismo deve } \\
\text { atender a legistação federal e estadual; deve } \\
\text { adotar o critério de capacidade de carga e } \\
\text { técnicas de manejo; e a criação do Pq estadual } \\
\text { dos Pireneus, mas contraditoriamente, na prática, } \\
\text { não há cobrança por parte da prefeitura de tais } \\
\text { critérios quando da implantação por exemplo de } \\
\text { atrativos em meios naturais. }\end{array}$ \\
\hline \multirow{6}{*}{$\begin{array}{c}\text { Território ; } \\
\text { Espaço }\end{array}$} & $\begin{array}{l}\mathrm{R} \\
\mathrm{U}\end{array}$ & Concepção & $\begin{array}{l}\text { Espaço é visto como recipiente em que "agentes } \\
\text { públicos e privados são os únicos tanto a atuar na } \\
\text { produção como gestão" deste. }\end{array}$ \\
\hline & \multirow{2}{*}{$\begin{array}{l}\text { R } \\
\text { I } \\
\text { C } \\
\text { A } \\
\text { S }\end{array}$} & Dificuldades & \\
\hline & & Avanços & $\begin{array}{l}\text { Pelo menos em tese considerar a sustentabilidade } \\
\text { "compatibilizando o desenvolvimento físico } \\
\text { territorial com a preservação do meio ambiente, } \\
\text { do patrimônio histórico e o desenvolvimento } \\
\text { socioeconômico". }\end{array}$ \\
\hline & \multirow{3}{*}{$\begin{array}{l}\text { S } \\
\text { U } \\
\text { B } \\
- \\
\text { R } \\
\text { U } \\
\text { B } \\
\text { R } \\
\text { I } \\
\text { C } \\
\text { A } \\
\text { S }\end{array}$} & $\begin{array}{l}\text { Totalidade/ } \\
\text { Fragmentação }\end{array}$ & $\begin{array}{l}\text { Pensar a ordenação do município seria a } \\
\text { totalidade, no entanto, não há menções no plano } \\
\text { no que tange aos povoados que fazem parte do } \\
\text { município. Sequer estes são mencionados. }\end{array}$ \\
\hline & & Teoria/Prática & $\begin{array}{l}\text { Embora o programa de estruturação urbana } \\
\text { (capítulo III) do plano preveja “dotar os bairros } \\
\text { da cidade das condições necessárias para a } \\
\text { melhoria da qualidade de vida (habitação, saúde, } \\
\text { lazer esportes, assistência social e segurança) da } \\
\text { população, na prática o programa traz somente } \\
\text { alguns projetos especiais que abarcam somente } \\
\text { alguns bairros da cidade. Embora a ideia de } \\
\text { implantação de Projetos de parques lineares seja } \\
\text { interessante, no entanto na prática não foi } \\
\text { contemplado em sua totalidade e abarcou somente } \\
\text { uma parte específica da cidade (Projeto Beira Rio), } \\
\text { sobretudo o centro histórico, parte da cidade em que } \\
\text { há mais evidência do turismo. Equipamentos de lazer } \\
\text { não foram implantados (conforme proposto no } \\
\text { projeto) à exceção de melhoria do campo que já } \\
\text { existia para a prática de esportes, nem iluminação } \\
\text { especial ou praças urbanizadas. O único projeto } \\
\text { implantado dentre os } 3 \text { propostos pelo plano foi o } \\
\text { Beira Rio e mesmo assim somente a parte que } \\
\text { abarca o centro histórico. }\end{array}$ \\
\hline & & Autonomia/ & \\
\hline
\end{tabular}




\begin{tabular}{|c|c|c|c|}
\hline & & Dependência & \\
\hline & & $\begin{array}{l}\text { Criticidade/ } \\
\text { Alienação }\end{array}$ & \\
\hline & & $\begin{array}{l}\text { Subjetividade/ } \\
\text { Objetividade }\end{array}$ & \\
\hline & & $\begin{array}{l}\text { Contradições/ } \\
\text { Mediações }\end{array}$ & \\
\hline \multirow{5}{*}{$\begin{array}{c}\text { Relações de } \\
\text { Capital/Trabalho }\end{array}$} & $\begin{array}{l}\text { R } \\
\mathbf{U} \\
\mathrm{B} \\
\mathrm{R}\end{array}$ & Concepção & $\begin{array}{l}\text { O desenvolvimento de atividades turísticas, } \\
\text { atividade da produção mineral e de produção de } \\
\text { atividade artesanal são foco do programa de } \\
\text { geração de emprego e renda do plano. O plano } \\
\text { traz diferentes ações voltadas ao } \\
\text { desenvolvimento de cada atividade. }\end{array}$ \\
\hline & I & Dificuldades & \\
\hline & $\begin{array}{l}\mathrm{C} \\
\mathrm{A} \\
\mathrm{S}\end{array}$ & Avanços & \\
\hline & $\begin{array}{l}\text { S } \\
\text { U } \\
\text { B } \\
- \\
\text { R } \\
\text { U }\end{array}$ & $\begin{array}{l}\text { Totalidade/ } \\
\text { Fragmentação }\end{array}$ & $\begin{array}{l}\text { O plano traz a perspectiva de desenvolver } \\
\text { atividades (turísticas, mineral e artesanato) com } \\
\text { vistas a geração de emprego e renda, no entanto } \\
\text { as ordenações e ações demonstram e contemplam } \\
\text { o meio ambiente, os "bens" históricos e não } \\
\text { contemplam o trabalhador, exceto a produção de } \\
\text { artesanato, em que o plano prevê a criação de um } \\
\text { "centro de produção e capacitação" dos e para os } \\
\text { artesãos }\end{array}$ \\
\hline & $\begin{array}{l}\text { B } \\
\text { R } \\
\text { I } \\
\text { A } \\
\text { S }\end{array}$ & Teoria/Prática & $\begin{array}{l}\text { Embora sejam priorizadas tais atividades, na } \\
\text { prática, a maioria das proposições estão voltadas } \\
\text { ao desenvolvimento da atividade turística. } \\
\text { Embora o plano preveja a criação de um centro } \\
\text { de produção e capacitação dos e para os artesãos, } \\
\text { na prática essa ação não se consolidou, passados } \\
13 \text { anos a única iniciativa de apoio á” produção } \\
\text { artesanal" na verdade se traduz em um apoio "á } \\
\text { comercialização" através de um espaço para } \\
\text { comercialização do artesanato, mas mesmo assim } \\
\text { o espaço é pequeno. E há uma outra iniciativa } \\
\text { que é a criação de um centro de assistência social } \\
\text { que oferece cursos de artesanato, mas que não } \\
\text { focados nas práticas artesanais tradicionais de } \\
\text { Pirenópolis como a tecelagem, prata, cestaria e } \\
\text { cerâmica. Não tem foco na capacitação }\end{array}$ \\
\hline
\end{tabular}




\begin{tabular}{|c|c|c|}
\hline & & /qualificação profissional. \\
\hline & $\begin{array}{l}\text { Autonomia/ } \\
\text { Dependência }\end{array}$ & \\
\hline & $\begin{array}{l}\text { Criticidade/ } \\
\text { Alienação }\end{array}$ & $\begin{array}{l}\text { O apoio "á comercialização" dada ao artesanato, } \\
\text { através de um espaço dedicado a tal } \\
\text { comercialização, pode ser encarado como em } \\
\text { apenas agregar valor á "atividade turística". Pois } \\
\text { se de fato o compromisso fosse com o fomento á } \\
\text { atividade artesanal ao menos a ideia de criação de } \\
\text { um centro de produção e capacitação já deveria } \\
\text { ter sido materializada. }\end{array}$ \\
\hline & $\begin{array}{l}\text { Subjetividade/ } \\
\text { Objetividade }\end{array}$ & \\
\hline & $\begin{array}{l}\text { Contradições/ } \\
\text { Mediações }\end{array}$ & $\begin{array}{l}\text { A atividade agropecuária embora seja a segunda } \\
\text { atividade em geração de PIB (embora no } \\
\text { imaginário e censo coletivo a segunda seja a } \\
\text { "produção mineral”) da cidade, conforme } \\
\text { constatado pelos dados IMB/SEPLAN (análise } \\
\text { período } 2003 \text { a 2012), não é contemplada pelo } \\
\text { plano. }\end{array}$ \\
\hline \multirow{4}{*}{ Cidadania } & Concepção & $\begin{array}{l}\text { O plano se compromete em "contribuir para a } \\
\text { implantação de um processo de planejamento } \\
\text { permanente e participativo, no sentido da } \\
\text { democratização da gestão urbana e territorial". }\end{array}$ \\
\hline & Dificuldades & $\begin{array}{l}\text { Conseguir de fato o envolvimento da comunidade } \\
\text { e criar os mecanismos para que esse processo se } \\
\text { efetive. }\end{array}$ \\
\hline & Avanços & \\
\hline & $\begin{array}{l}\text { Totalidade/ } \\
\text { Fragmentação }\end{array}$ & $\begin{array}{l}\text { O plano traz um artigo que faz referência especial } \\
\text { aos passeios públicos que deverão permitir a } \\
\text { trafegabilidade das pessoas, garantindo conforto } \\
\text { e segurança considerando os aspectos: } \\
\text { escoamento de águas pluviais, conforto á } \\
\text { rugosidade do calçamento e desníveis e } \\
\text { reentrâncias do piso. Há no entanto um parágrafo } \\
\text { que estabelece o melhoramento das vias do } \\
\text { centro histórico que deve ser adequada de forma } \\
\text { a permitir a locomoção de pessoas portadoras de } \\
\text { deficiência física e da terceira idade, embora a } \\
\text { geometria do centro histórico seja composta por } \\
\text { diversas ruas que dificultam a mobilidade, isso } \\
\text { não justifica que a ação de melhoraria da } \\
\text { mobilidade de pessoas que tenham a mobilidade } \\
\text { reduzida (deficientes, pessoas idosas) deva se dar } \\
\text { somente no centro histórico. }\end{array}$ \\
\hline
\end{tabular}




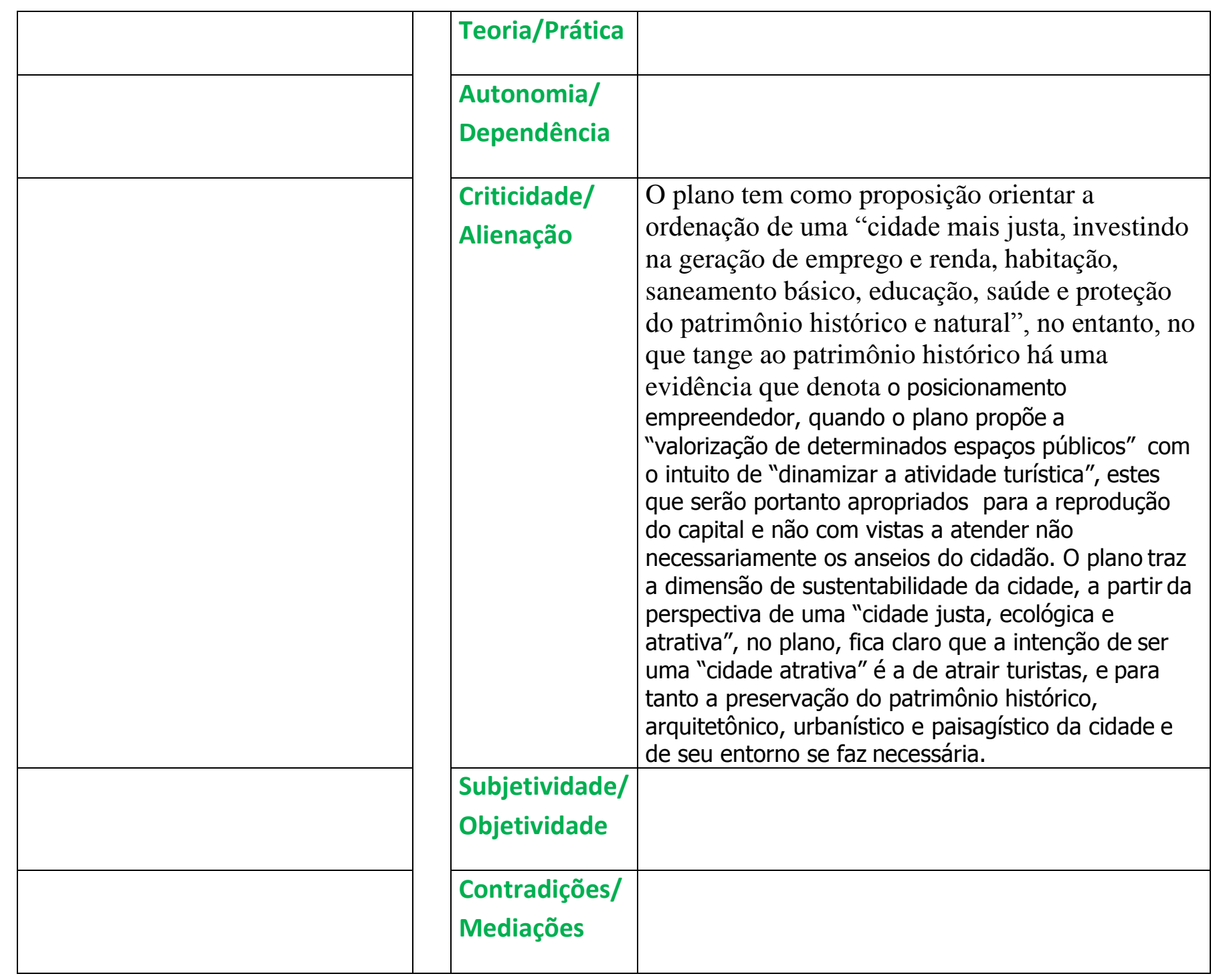

